\title{
Britain's Imperial Cornerstone in China
}

\author{
The Chinese Maritime Customs \\ Service, 1854-1949
}

The Chinese Maritime Customs Service was an institution that for over 80 years held an integral role in facilitating foreign trade along the China coast and waterways. Established as the Imperial Maritime Customs Service in the wake of China's defeat in the Opium Wars (1842-3), it became a central feature of the Treaty Port system. This British-dominated service also encompassed other responsibilities such as harbour maintenance, lighthouse service, quarantine, anti-piracy patrols and postal services. The Maritime Customs Service sat at a crucial juncture between Chinese and foreign interests, and was intimately linked to British interests and fortunes in the Far East (most particularly through the aspirations of the British Inspectors General at its helm). It was these inherent conflicting interests that led the Service to face serious challenges to its integrity in the 1920s and 1930s; and these challenges are examined in detail in this work.

This book provides an overview of the development of the Chinese Maritime Customs Service as an essentially imperial institution focusing especially on the fate of the foreign inspectorate in its last decades when it faced challenges from nationalist elements, civil unrest and war, compounded with tensions between the inspectorate and British interests in China.

Donna Brunero is a Research Fellow in the Department of Historical Studies, University of Bristol. 


\section{Routledge Studies in the Modern History of Asia}

1 The Police in Occupation Japan Control, Corruption and Resistance to Reform

Christopher Aldous

2 Chinese Workers

A New History

Jackie Sheehan

3 The Aftermath of Partition in South Asia

Tai Yong Tan and Gyanesh

Kudaisya

4 The Australia-Japan Political Alignment

1952 to the Present

Alan Rix

5 Japan and Singapore in the World Economy

Japan's Economic Advance into Singapore, 1870-1965

Shimizu Hiroshi and Hirakawa Hitoshi

6 The Triads as Business Yiu Kong Chu

7 Contemporary Taiwanese Cultural Nationalism A-chin Hsiau

8 Religion and Nationalism in India

The Case of the Punjab Harnik Deol
9 Japanese Industrialisation Historical and Cultural Perspectives Ian Inkster

10 War and Nationalism in China 1925-1945

Hans J. van de Ven

11 Hong Kong in Transition One Country, Two Systems Edited by Robert Ash, Peter Ferdinand, Brian Hook and Robin Porter

12 Japan's Postwar Economic Recovery and Anglo-Japanese Relations, 1948-1962 Noriko Yokoi

13 Japanese Army Stragglers and Memories of the War in Japan, 1950-1975

Beatrice Trefalt

14 Ending the Vietnam War The Vietnamese Communists' Perspective Ang Cheng Guan

15 The Development of the Japanese Nursing Profession

Adopting and Adapting Western Influences Aya Takahashi

16 Women's Suffrage in Asia Gender Nationalism and Democracy Louise Edwards and Mina Roces 
17 The Anglo-Japanese Alliance, 1902-1922

Phillips Payson O'Brien

18 The United States and Cambodia, 1870-1969

From Curiosity to Confrontation

Kenton Clymer

19 Capitalist Restructuring and the Pacific Rim

Ravi Arvind Palat

20 The United States and Cambodia, 1969-2000

A Troubled Relationship

Kenton Clymer

21 British Business in Post-Colonial Malaysia, 1957-70

'Neo-colonialism' or

'Disengagement'?

Nicholas J. White

22 The Rise and Decline of Thai Absolutism

Kullada Kesboonchoo Mead

23 Russian Views of Japan, 1792-1913

An Anthology of Travel Writing David N. Wells

24 The Internment of Western Civilians under the Japanese, 1941-1945

A Patchwork of Internment

Bernice Archer

25 The British Empire and Tibet 1900-1922

Wendy Palace

26 Nationalism in Southeast Asia If the People Are With Us

Nicholas Tarling

27 Women, Work and the Japanese Economic Miracle The Case of the Cotton Textile Industry, 1945-1975

Helen Macnaughtan
28 A Colonial Economy in Crisis Burma's Rice Delta and the World Depression of the 1930s Ian Brown

29 A Vietnamese Royal Exile in Japan

Prince Cuong De (1882-1951)

Tran My-Van

30 Corruption and Good Governance in Asia Nicholas Tarling

31 US-China Cold War Collaboration, 1971-1989

S. Mahmud Ali

32 Rural Economic Development in Japan

From the Nineteenth Century to the Pacific War

Penelope Francks

33 Colonial Armies in Southeast Asia Edited by Karl Hack and Tobias Rettig

34 Intra Asian Trade and the World Market

A.J.H. Latham and Heita

Kawakatsu

35 Japanese-German Relations, 1895-1945

War, Diplomacy and Public

Opinion

Edited by Christian W. Spang and Rolf-Harald Wippich

36 Britain's Imperial Cornerstone in China

The Chinese Maritime Customs

Service, 1854-1949

Donna Brunero 



\section{Britain's Imperial Cornerstone in China}

The Chinese Maritime Customs

Service, 1854-1949

\section{Donna Brunero}

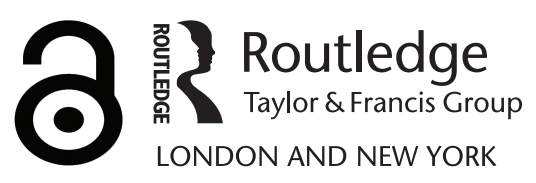


First published 2006

by Routledge

Published 2017 by Routledge

2 Park Square, Milton Park, Abingdon, Oxon OX14 4RN

711 Third Avenue, New York, NY 10017, USA

Routledge is an imprint of the Taylor \& Francis Group, an informa business

Copyright (C) 2006 Donna Brunero

Typeset in Times New Roman by

Florence Production Ltd, Stoodleigh, Devon

The Open Access version of this book, available at

www.tandfebooks.com, has been made available under a Creative

Commons Attribution-Non Commercial-No Derivatives 4.0 license.

British Library Cataloguing in Publication Data

A catalogue record for this book is available

from the British Library

Library of Congress Cataloging in Publication Data

Brunero, Donna

Britain's imperial cornerstone in China: the Chinese maritime customs service, 1854-1945/Donna Brunero

p. $\mathrm{cm}$

Includes bibliographical references and index.

1. Great Britain - Foreign relations - China. 2. China - Foreign relations - Great Britain. 3. Great Britain - Foreign relations 19th century. I. Title.

DS740.5.G5B78 2006

$352.4^{\prime} 48^{\prime} 095109034-\mathrm{dc} 22$

2005018916

ISBN13: 978-0-415-32619-3 (hbk) 
For my parents 



\section{Contents}

List of illustrations

Preface

Acknowledgements

$\mathrm{x}$

List of abbreviations

xiii

$\mathrm{XV}$

1 Introduction

2 An institutional review 22

3 Gunboats and revenue, 1923-7 54

4 Nationalist ascendancy and the politics of being Inspector General

5 Charting a new course: the proposed Hong Kong-China Trade and Customs Agreement, 1929-30

6 A Service in decline

7 'Steadfast and fearlessly persistent': the CMCS in the face of war, 1937-45

Notes

Bibliography

Index 


\section{Illustrations}

\section{Tables}

1.1 The opening of treaty ports and Customs houses 12

2.1 Selected Customs Commissioners of $1911 \quad 25$

2.2 Revenue and receipts of the Nationalist Government, 1929-34

2.3 Revenue of the Maritime Customs Service, 1923-37

\section{Figures}

2.1 Structure of the Maritime Customs Service, c.1922

2.2 Customs Commissioner's house, Macao c.1926 with Le Bas family in the foreground

2.3 Customs Commissioner's house, Macao c.1926; Commissioner Le Bas entertaining guests 50

2.4 View over Macao from the Customs Commissioner's house $\quad 50$

2.5 Social function aboard a Customs Cruiser, hosted by Commissioner Le Bas c.1926

2.6 Social function aboard a Customs Cruiser, hosted by Commissioner Le Bas c.1926

6.1 Sapajou, 'A Domestic Question - What it is no use crying over'

6.2 Sapajou, 'Heads or Haunches? The shadow and the substance' 


\section{Preface}

It is common knowledge that during the past eight or nine decades the quasiBritish controlled Inspectorate of Customs has hitherto been a corner-stone of British position in China and has been co-equal with the name of England in the Far East. And it should be considered furthermore, that the influence and prestige of the Inspectorate General throughout this period was attained and sustained solely by individual exertions

Sir Frederick Maze, 21 December $1943^{1}$

So wrote the recently retired Inspector General (IG) of the Chinese Maritime Customs Service (CMCS), Sir Frederick Maze, the determined and sometimes unpopular leader of this service from 1929 to 1943. After an embattled and embittering term as IG, marked by the resistance of Chinese nationalist forces and British Foreign Office indifference, Maze's resignation in late May 1943 brought to a close over 80 years of British predominance in the CMCS. This institution, greatly diminished as a result of the SinoJapanese War, continued to function under an American IG and relocated to Taiwan in 1949. This work examines the twilight period of this Service, particularly the growing turbulence it encountered in the 1920s and 1930s, and early 1940s through Chinese nationalism, British Foreign Office indifference and Japanese aggression. In doing so I explore the anomalies presented by this imperial institution, and examine how perceptions of the Service and its role changed over these years.

This work draws on Customs documents, personal papers, newspaper reports and British Foreign Office correspondence among other sources to build a picture of this institution. The Imperial Maritime Customs Service (IMCS), known as the Chinese Maritime Customs Service from 1912, was indeed Chinese in name but its British leadership and close links to British and foreign interests in China reflect its intimate ties to the treaty port system and to foreign ambitions in the Far East. Based on English language sources, this study provides British perceptions of this institution, and in this way contributes to imperial studies. There is certainly a place for understanding the Maritime Customs Service as an imperial institution or, as Maze would term it, an 'outpost of British Empire' in the Far East. 


\section{xii Preface}

At present a project is under way (the Chinese Maritime Customs Project) to open and make accessible voluminous Customs records contained in the Second Historical Archives of China in Nanjing. This project, involving collaboration between historians at Bristol and Cambridge Universities and archivists and researchers at the Second Historical Archives, Nanjing, will see the production of detailed catalogues, datasets and bound volumes of documents. In light of this project, this work, based on my doctoral dissertation, seeks to lay a basic groundwork on the Maritime Customs Service with the belief that in years to come more detailed studies will flesh out our understanding of this institution and its part in British and Chinese history. 


\section{Acknowledgements}

The basis of this work was completed as my doctoral dissertation with the assistance of an Australian Postgraduate Award. The scholarship enabled my study at the University of Adelaide, as a joint candidate of the Department of History and Centre for Asian Studies, under the co-supervision of Associate Professor Yen Ching-hwang and Dr Carney Fisher. I count myself as particularly fortunate to have had the opportunity to work under such dedicated scholars and appreciate their encouragement and inspiration. Thank you also to Associate Professor Robert Lee from my undergraduate days for pointing me to this research in the first instance. Revisions to this work and manuscript were made possible through a Postdoctoral Fellowship with the Department of History at the National University of Singapore. Associate Professor Tan Tai Yong, Professor Ng Chin-keong and Associate Professor Huang Jianli had significant part in welcoming me in this post. Further work has been made possible through a Visiting Fellowship with the Department of History.

Librarians, archivists and museum curators all added a crucial dimension to this work, for which I am most thankful. In particular, Margaret Hosking of the Barr Smith Library (University of Adelaide) gave invaluable assistance in the early stages of this research. And staff from the SOAS Library, St Antony's and Rhodes House Oxford, as well as the National Maritime Museum Greenwich (NMM), were both accommodating and knowledgeable. Thank you also to the NMM for allowing the reproduction of the fine image of Sir Frederick Maze (MS79/165/2) in this monograph. Further to this, graduate student $\mathrm{Hu}$ Wen also gave valuable assistance in the final revision stages.

To have contact with former Customs staff added a personal dimension to this work. I am grateful to Mrs Yvonne King, Mr and Mrs Anthony Hewitt and Mr Christopher Briggs for sharing aspects of their China experiences with someone who had no 'China connection'. I especially appreciate Mrs King's generosity in making her family photo albums available to me.

Family and friends played a crucial role as my scholarship has and will continue to develop. It is from this base that I have found understanding, 


\section{xiv Acknowledgements}

support and encouragement. Thanks go to my relatives, Peter and Milan, for their hospitality during my UK sojourn in 1997 (and who offered me a chance to develop tastes for a lifestyle no student budget can afford!). I am grateful to my parents, Don and Kathleen, and to my siblings, Louise, Adam and Anne, for their love and faith. And I am also appreciative of the way I have been welcomed into the Yew family.

And most importantly, thank you to my husband, Leong, for his faith in my seeing this to fruition despite the chaos I inevitably wrought on our home study. Leong's patience and sacrifices are all the more special as he is currently making a mark with his own research. Finally, for our son Dominic Meng Yi, whose arrival in 2004 provided a wonderful distraction from manuscript revisions.

Any shortcomings in this work are, alas, mine alone. 


\title{
Abbreviations
}

\author{
CCP Chinese Communist Party \\ CMCS Chinese Maritime Customs Service \\ CYB China Year Book \\ GMD Guomindang \\ Hk.Tl Haikwan tael \\ IG Inspector General \\ IMCS Imperial Maritime Customs Service \\ LO London Office \\ NCDN North-China Daily News \\ $\mathrm{NCH} \quad$ North-China Herald \\ NRS Non-Resident Secretary
}





\section{Introduction}

From its inception in the 1850s the Imperial Maritime Customs Service (IMCS) was a uniquely cosmopolitan institution dominated by British nationals. Stretching along the China coast and penetrating inland along waterways, the Service represented a vast network of over 40 Customs stations and sub-branches monitoring and regulating foreign trade with China. Its influence, however, reached far beyond tariffs and trade, ensuring its survival in the uncertain years of the early Republic (1911) and beyond; it was arguably the most important institution in China during the Republic. With a history of strong leadership from its successive Inspectors General (IG) - Horatio Nelson Lay (1859-63), Robert Hart (1863-1911), Francis Aglen (1911-27), Frederick Maze (1929-43) and Lester Knox Little (1943-50) - the key to the existence of the Service was undeniably through the treaty port system. Without foreign presence and privilege in China, reinforced though the Unequal Treaties and preserved by gunboat diplomacy, this Service would never have come into being nor would it have endured into the Republic.

The Service was born out of China's tumultuous encounters with the West in the nineteenth century. It was a central element of the treaty port system that had forced the opening of China to Western trade and residence. And it encompassed far more than the collection of import and export duties; it was also responsible for lighthouses, harbour maintenance, postal service, quarantine and anti-piracy measures among other duties. By the dawning of the Chinese Republic, however, it had become an anomaly. It was a potent reminder of China's humiliation at the hands of the West, but at the same time remained a major source of revenue for the Chinese Government. Despite being drawn inexorably closer to Chinese political affairs from 1911 onwards under the leadership of Aglen and Maze, the Service (from 1912 known as the Chinese Maritime Customs Service or CMCS) perceived itself as representing and advancing not just foreign trade interests in China but more specifically British interests.

This work explores the CMCS during the Republic, paying particular attention to the development of this institution. The Service was not static; it had to change to ensure its survival in the increasingly nationalistic 


\section{Introduction}

climate. These changes, however, led to perceptible alterations in the significance of the Service to both Western and Chinese interests. In particular British attitudes towards the Customs underwent a dramatic shift from the time when Britain was dominant in encouraging a multinational gunboat demonstration to defend the Guangzhou Customs in 1923 to its hesitant and unofficial protests to the Manzhouguo authorities over the seizure of north-eastern Customs houses in 1932. While the British Foreign Office generally believed their interests in the CMCS had been eroded with the rise of Chinese nationalism, the perception within the Service was that it continued to provide a valuable service to British interests in China. This imperial institution rapidly found itself associated with a 'bygone era' and by the 1940s had largely faded from Britain's view.

This work explores how and why the foreign administration of the Customs survived the transition from Imperial times to the Republic and the effect of its encounters with nationalist China. In doing so, the themes of resistance and change emerge; the Service encountered growing Chinese resistance to the foreign inspectorate, changing political landscapes both in China and the West, and the resisting of change by some elements of Customs leadership as well as the British Foreign Office and the diplomatic body. The burgeoning of Chinese nationalism in the 1920s presented resistance to the basis of the foreign inspectorate that took the forms of anti-foreignism and anti-imperialism. Aglen and Maze took different approaches to navigating such oppositions and stresses but both with the intention of keeping the foreign inspectorate intact. As a result, the CMCS therefore had a shifting significance to both Western and Chinese interests throughout the Republic and this work explores the junctures when the foreign basis of the Service was called into question.

The 1920 s through to the 1940 s provide the overarching timeframe for this research and were particularly turbulent from the viewpoint of China's internal politics. The 1920s are largely marked by the peak and then decline of warlordism and the subsequent rise of the Nationalist movement culminating in the dominance of the Guomindang (GMD) and the Nanjing Decade. The 1930s brought increasing tensions from Japanese ambitions in the north-east, culminating in the Sino-Japanese War. The Service was both directly and indirectly affected by these developments. Staff found themselves the focus of anti-foreign attacks and Customs houses needed foreign protection to ensure they could maintain their regular duties. As Nationalist forces harnessed anti-foreign feeling with powerful results, the foreign powers were faced with the realization of the need to recast their relationship with China. Academics such as Clifford and Fung in particular have presented this reshaping of policy as part of a particularly British decline and retreat from China. ${ }^{1}$ The chronicling of this diplomatic retreat leads to the question: what was the fate of the foreigndominated CMCS in such a climate of gradual withdrawal? By examining the Service through case studies the decisive shift in British foreign policy 
in China (enunciated in the December Memorandum of 1926) can be clearly detected. During the Republic the Service can be broadly presented as reflecting some of the main forces in Sino-Western relations but on closer examination the CMCS often diverges from the expected pattern. The most prominent example of this divergence was its ability to survive until the 1940s (albeit with diminished influence) when the Chinese Government had absorbed other foreign-dominated Chinese institutions such as the salt administration.

Imperialism, but more specifically, British imperialism and its manifestations in China is a predominant theme in this work. China was never a British colony and was never formally adopted into the realm of the British Empire, but it did form an undeniably important part of British ambitions for the Far East. While there was an absence of a formal colonialism, the Service stood as a manifestation of British imperialism in Republican China; not unlike the Indian Civil Service, its staff were inculcated with the imperial mindset and there was an ever-present division between foreign and 'native' staff. Bickers' work Britain in China strongly argues that the imperial mentality was evident in the 'settler communities' in the treaty ports. ${ }^{2}$ And at each treaty port, the CMCS was a key institution, its senior staff prominent in the foreign community. Through the CMCS Britain was able to interfere with or at the least exert pressure over political events in China for this institution straddled Chinese and foreign realms of interest.

The CMCS, with its foreign inspectorate, was a key part of the treaty port system and possessed the potential to serve as a prime mechanism for exercising foreign influence in China's affairs. It represented not only a large source of revenue for the Chinese Government but was also the main security for foreign loans to China. The CMCS, however, has received relatively low coverage in discussions of imperialism and its manifestations in the Republic. ${ }^{3}$ One notable exception is that of Jürgen Osterhammel. ${ }^{4}$ In his attempts to find a framework for analysing imperialism in the Chinese context, the CMCS, with its foreign de facto leadership and yet Chinese status, is cited as an anomaly for researchers. However, it was commonly grouped under the banner of imperialism without due attention to its unusual basis. During the Republic the Service was indeed representative of British influence in China and, despite waning British commitment to the CMCS, the Service remained an avenue for potential interference.

Researching the CMCS is in essence an exploration of Sino-Western relations and their changing face through the Republic. In this way two broad theories of Sino-Western relations can be placed on the Customs, that of the 'oppression' school and 'beneficial' school. ${ }^{5}$ There has been a move (Rawski for example) for a 'marginalization' approach to explain Western contact with China. ${ }^{6}$ Essentially did the CMCS act as an agent for oppressing the Chinese economy and society? Did it fulfil a benevolent role of guiding the Chinese into a modern, fiscal system and providing 
a regular income for the Chinese Government? Was the Customs merely an adjunct to the treaty port system? Did its existence and regulatory methods fail to affect anything outside the safe haven of the ports? The anomaly presented by the Customs Service is apparent as an argument can be made for and against each of these questions.

The CMCS is of interest as an imperial and maritime institution. Studies of imperial institutions have undergone a resurgence of late, providing fresh examinations of these important mechanisms of empire and their administrators. This includes work by scholars such as Kirke-Greene on the Indian Civil Service, Sudan Political Service and Colonial Service; ${ }^{7}$ McKay on the Tibet Cadre; ${ }^{8}$ and Strauss ${ }^{9}$ on China's Sino-Foreign Salt Inspectorate among others. This work makes a contribution to this growing field. So too, the development of research in China's maritime history was the subject of a detailed historiographical review by Chi-Kong Lai in 1995. ${ }^{10}$ This review confirmed the fact that there are at present few English language works on the CMCS. This work attempts to further augment China's maritime history through a signposting of materials available in English language. Consequently this research draws on, among other materials, the well-documented collections at London University's School of Oriental and African Studies and also on the lesser-known Maze Collection at the National Maritime Museum, Greenwich, the Clementi Papers at Rhodes House Library, Oxford, and British Foreign Office and Colonial Office papers.

Significant events embroiling the Customs exemplify the dynamic nature of the Service in responding to forces of resistance that were produced by changing British and Chinese interests. Unsurprisingly these interests were often at odds with each other; the Chinese pursuing of nationalistic aims and the British attempting to protect their political and commercial interests. In some cases these tokens of resistance were not split neatly between the Chinese and British, and each party had its own stories of internal dissension and embittered rivalry. The year 1923 is a significant starting point for this work as it was in this year that 'Father of the Republic', the revolutionary Dr Sun Yatsen made a threat against the revenue of the Guangzhou Customs. This was an unprecedented challenge to the CMCS and a foreign naval demonstration assembled in its defence; the Service was able to carry on unmolested. From this time on, however, the Service encountered a growing number of threats and found it could no longer rely on the foreign powers to help defend its interests. This study concludes with the 1940s and the end of British leadership of the Service. This research allows for an examination of the CMCS in light of the decline of warlordism, the Nanjing decade and also internal tensions within the Service. Examining selected incidents has twofold significance: previously obscure areas of CMCS history are given greater clarity and these incidents individually and cumulatively allow the development of a historical narrative on the CMCS as representative of foreign interests and presence in 
China. Customs circulars (both official and semi-official), annual reports, and official and private correspondence all contribute to Customs perspective of these incidents.

The golden era of Western imperial presence in China as typified through gunboat diplomacy and the Unequal Treaties can be seen as a more glamorous prospect than the waning star of Western privilege in China, which was feared and then realized in the Republic. By focusing on the Customs in this much later period, however, this work seeks to redress some of the imbalance of academic attention. ${ }^{11}$ The emphasis in this work is not solely on the CMCS as an institution but on the historical and political context within which it operated. In keeping with the foreign focus in this research, this work draws on English language sources. While taking an Anglocentric approach may attract criticism, one must reflect that the CMCS was indeed a Western-styled, British-dominated institution and, in most instances, actively protected Western interests in China. This is also in keeping with the fact that the Inspectorate of Customs was undisputedly British dominated. For this reason I believe that an Anglocentric approach provides a valuable insight into the functioning and mindset of the Inspectorate.

The structure of this work is broadly chronological. Chapter 2 sets the scene with an institutional review of the CMCS. This review examines the Service in light of its bureaucracy, fiscal responsibilities and the role of its London office. It also explores the nature of life in the Service for foreign staff. Chapters 3 to 7 each trace incidents that affected the Service. Chapter 3 examines reaction to Sun Yatsen's threat against the Guangzhou Customs and also observes CMCS reaction to the Guangzhou-Hong Kong boycott. Chapter 4 looks inside the Service and explores the ramifications of the succession crisis which arose following Aglen's dismissal. Chapter 5 investigates the revival of negotiations for a Hong Kong-China Trade and Customs Agreement (1930) as evidence of a new direction for the CMCS. Chapter 6 details the decline of the CMCS as evidenced through attacks on the integrity of the Service with a takeover at Tianjin Customs house. Chapter 7 provides an overview of the Service in the face of the SinoJapanese and Pacific Wars. This marked the end of British leadership of the Service.

\section{Explaining the CMCS}

The organization of the CMCS has been described in various terms by both its contemporaries and by academics. The following pages explore how the Customs saw itself and also how academics assessed the Service. This evaluation is pertinent because the Customs occupied such an unusual position in China; it was a Chinese department but at the same time was dominated by foreigners and had close links to foreign interests in China. Within the Service a number of records and documents were produced that described the organization and what it represented. These included letters, 


\section{Introduction}

memoranda and Customs publications. The focus of this discussion is therefore with the official views and those expressed by leaders Hart, Aglen and Maze. The more informal impressions of the Service can be found in a number of memoirs and even poetry; these are introduced at various stages throughout this work.

As the development of the Customs Service was shaped to a large extent by the vision of the IG, it is necessary to review how each respective leader perceived the organization they were heading. Their attitudes can be surmised through their correspondence on the Service. In his development and guidance of the IMCS through its early years, Hart consistently described the Service in terms of its being a Chinese institution, established to serve the Chinese court and people above all else. He did, however, also see that the Customs also represented Western values and had a role to play in promoting these values in China. ${ }^{12}$ The focus was, however, on the Customs' responsibility to the Chinese court.

By the Republic this view of the CMCS had undergone a shift. Aglen attempted to describe what he saw as the stages through which the Custom Service had progressed. In a letter to the London Office (LO) Non-Resident Secretary (NRS) in 1922 Aglen mused that the Customs had passed through two stages and was entering a third. The stages were as follows: first, as a purely Chinese institution supported by the Chinese because they performed a useful service; second, the proliferation of foreign loans and coming of the revolution gave the Customs more control over revenue, making the service a foreign caisse de la dette; and the third stage, as warlords vied for political dominance, the customs became an imperium in imperio asking foreign powers for advice and not the Chinese. ${ }^{13}$ Certainly, the focus on being servants of the Chinese powers had shifted and in its place was a more self-righteous idea that the Customs knew what was best for the young Republic.

Under the leadership of Maze, moreover, perceptions of the Service shift again. Maze describes the Customs as an 'unofficial outpost of British Empire' and throughout his correspondence speaks of the difficulties in preserving British interests in the Service. Moreover, empire became a reference point for Maze and he often mentioned the parallels between his organization and that of the Indian Civil Service. ${ }^{14}$ In this way the CMCS is represented as part of a larger scheme of British (and foreign in a more general sense) presence in Asia.

As can be seen from the above discussion, attitudes towards what the CMCS represented changed markedly over time, in response not only to personalities but to larger forces at play. Aglen in particular encountered a turbulent number of years during his leadership, culminating in his dismissal; hence his descriptions of the Customs as representing a vehicle for order in China are not unexpected. Maze's attitude too reflected the tensions he encountered with the British Foreign Office and the belief that he had been abandoned to defend the Customs alone. 
A predominant contributor to work on the CMCS is Stanley Fowler Wright, who was not only a distinguished Customs officer but has written what remain some of the most detailed accounts of the revenue and tariff aspects of the Customs service. ${ }^{15}$ Further to this, his work provides an insight into how the Service perceived itself to stand in relation to China and the treaty powers. Had Wright's work not followed a standard line accepted among the top echelons of the Customs there is little chance that it would have been published. An example of this being his first work, The Collection and Disposal of the Maritime and Native Customs Since the Revolution of 1911, With An Account of the Loan Services Administered by the Inspector General of Customs, as this study was published by the Statistical Department of the Inspectorate General of Customs in Shanghai. In a letter to Bowra, NRS of the LO, Aglen's cautious tone is evident:

Tell Stanley Wright to be very careful when discussing finance either with the Hongkong Bank or with the Foreign Office. His book is really a very wonderful piece of work and reflects the greatest credit on him, but it was a description of my doings and whatever he says he must be careful not to speak beyond the book. ${ }^{16}$

Although the title of the book is not mentioned specifically in this letter, it must have been Wright's first publication on the collection and disposal of Customs revenue that had been released at this time. Clearly any work endorsed and prefaced by the IG was expected to fulfil certain expectations of maintaining a standard discourse on the nature of the Service. Wright's work on the CMCS remains significant for researchers, not merely for its exhaustive attention to detail but also for the insights it provides as to what constituted accepted representations of the Service in the 1920s.

In a publication of 1950, Hart and the Chinese Customs, Wright presents the reader with a plethora of descriptions of the nature of the Service during its Imperial and Republican guises. While these comments range from the empirical and insightful to those that are grandiose and overstated, however, not surprisingly Wright's work always casts the CMCS in a positive light. Initially Wright presents the Service as:

an organisation controlled by the Imperial - and not the provincial authorities collecting revenue at all the open ports for the disposal of the Central Government, controlling foreign trade in accordance with treaties ratified by that Government, and in all other matters carrying out the orders of that Government. ${ }^{17}$

Within this description of the IMCS there is no mention of the essential Western element in the Service. In a later description, moreover, Wright 


\section{Introduction}

alludes to the injection of foreign supervision into the Service as causing aggravation to the Chinese, but even so this reflection still casts a positive glow on the CMCS:

the essential feature of the plan was the injection of the element of foreign supervision into a Chinese Government body, an injection which undoubtedly has wrought great and lasting benefit, but which has also acted as an irritant both internally and externally. ${ }^{18}$

Such comments display an awareness of the ambiguity of the foreign inspectorate in terms of the benefits and drawbacks it offered.

The international nature of the Service is given prominence in Wright's work. The Service is represented as larger than only Chinese concerns or only foreign interests but rather as an example of how 'international diversities can be fused to serve the interests of all'. ${ }^{19}$ The broader significance of the Service is developed further by Wright and he outlines the cosmopolitan nature of the Service, its international duties, range of interests and ideals of public service as the reasons why the Service had been termed a precursor of the League of Nations. Although this was certainly a grand comparison and Wright was quick to emphasize that the Service was only a China Service, he did stress that it still was cosmopolitan and indeed had benefited every nation on earth having dealings with China. He extolled:

For over eighty years the Service stood as a signpost on the road to international understanding and co-operation. ... In a world to be purged from the evil aggressiveness of perverted nationalism the example and experience of China's Customs Service indicate inspiring possibilities for the future. ${ }^{20}$

League of Nations allusions aside, clearly the Service had international significance in Wright's view; he invests it with a leadership role that extended far beyond the boundaries of China. Regardless of his pro-CMCS sympathies, Wright's reflections as an employee and chronicler of the Service are significant in that they provide officially sanctioned views of the Service.

\section{Contemporary views}

In his studies of treaty port China, Fairbank presented the IMCS as lying at the heart of the treaty port system and, therefore, of Sino-Western relations. Fairbank coined the term synarchy, denoting a symbiotic cooperation between China and foreigners (this was different from the dyarchy recognized to exist in British India). Synarchy was synonymous with a joint administration and as a distinctly Chinese phenomenon. ${ }^{21}$ In Chinese 
Thoughts and Institutions (1957) Fairbank explored the existence of synarchical relationships throughout China's history that took place before initial Western contacts with China. Western presence in China is situated as following these precedents of synarchy. Following this line of reasoning then, the treaty port arrangement was not simply enforced by the West, but was a compromise of sorts by both the Qing court and the West. This placed the Westerners within an accepted, traditional framework of power relations where their actions could, to some extent, be limited and monitored. In this understanding, the IMCS was cited as the most striking example of synarchy in modern China. The dawning of the Republic signalled the disintegration of synarchy. This leads to a necessary questioning of whether the customs (considered such a prominent example of synarchy) was recast in the Republic and, if so, how this was achieved and with what result. The Customs Service of the Republic poses difficulties to the historian when attempting to situate it within the synarchy thesis. Some researchers, however, presuppose the universality of this theory in describing the Customs throughout its existence without sufficient analysis to determine its suitability. In Atkin's Informal Empire in Crisis a chapter is titled 'Synarchy and Revenue' but there is little exploration of the implications of the Customs as a synarchy.22

The CMCS can be located within the context of British informal empire in China. Certainly the Service was a mechanism for foreign influence and interference in China's affairs. The informal empire theory and its application to China nevertheless rest uneasily with some academics. Dean and Osterhammel, for example, both express reservations when applying such paradigms to China. ${ }^{23}$ Informal empire has been put forward in a recent work by Bickers, Britain in China. ${ }^{24}$ The CMCS is cited in Bickers' work as representative of British informal empire. It is undeniable that the CMCS played a significant part in representing British and other foreign interests in China and that its fortunes were tied in a large way to the British presence in China. In support of this, it must not be forgotten that Maze described the Service as 'an outpost of British empire'. ${ }^{25}$ And perceptions from within the Service are significant to understanding this institution.

The CMCS can also be understood in institutional or structural terms. In her dissertation, Aitchison focuses on the Service as a Western fiscal organization and explores its development and adaptation from the Qing to the Republic. Subsequently the Customs is posited within Max Weber's critique of rational bureaucracy. ${ }^{26}$ Aitchison argues convincingly that this critique can be applied to the CMCS with a measure of success but stresses that Hart, at the time, had no such model on which to have planned the Service. The Service was indeed a highly centralized and well-disciplined service with a strict hierarchy for the efficient undertaking of predetermined goals and duties. In Max Weber's 'Authority and Legitimacy' the structures of a rational bureaucracy are outlined with loyalty to office 
stressed as being above that of the personalities. ${ }^{27}$ In addition, the CMCS has been compared to another hybrid organization at national level in China, the Salt Inspectorate, as it also had foreign leadership and staff composition and displayed similar structures and organizational aims. ${ }^{28}$

\section{The origins of the IMCS}

[T] he service was called into being for the express purpose of enforcing the impartial administration of China's treaty tariff at a moment when civil strife, lawlessness on land and sea, mercantile defiance of authority, and corrupt practices of both traders and officials had made that tariff, and the customs procedure enjoined by the treaties, 'more honoured in the breach than the observance'. ${ }^{29}$

The IMCS was created as a result of the Opium Wars and the Taiping Rebellion and it was intended to replace the pre-existing Chinese Customs system. This system was unregulated and the bane of foreign merchants in China. Arguably the irregularity of Customs in China, which left foreign traders at the mercy of often unscrupulous and arbitrary dealings by the Chinese, was one of the catalysts for the Opium Wars.

The intrusion of the Western powers along the coast of China provided a further external irritant (adding to the internal problems of rigid social strata and ethnic discrimination) for the massive upheaval of the Taiping Rebellion. Pirates and bandits were pushed inland and to the river systems largely as a result of the new foreign presence, and this further exacerbated social distress. This rebellion in turn gave opportunity for further Western (but particularly British) interference in Chinese affairs. The Taiping, led by Hong Xiuquan, a member of the Hakka (ke jia) ethnic minority who became embittered by his experiences of unsuccessful civil service exams, adopted the doctrine of Christianity as a spiritual and revolutionary force. In this way, the presence of foreign missionaries in China had also had some effect. Hong had reinterpreted Christian texts and was convinced of his destiny as the younger brother of Jesus to campaign for the salvation of China. ${ }^{30}$ The Taiping campaign against the Qing court threatened the dynasty's control for almost 15 years (1850-64) and, in their bid to establish their own kingdom (the so-called Kingdom of Heavenly Peace), the Taiping ravaged huge areas of the nation and crippled trade. ${ }^{31}$ A Taiping capital was established in Nanjing on 8 March 1853. The Taiping did not just oppose the Qing court but also many of the precepts of Confucianism. Customs chronicler, Wright, reflected on the final bloody overthrow of the Taiping Tianguo (heavenly kingdom), which saw the:

final extinction of those semi-Christian ideas, their early profession of which had at first misled so many missionaries and well wishers. Whatever the Taiping Rebellion may have been, or aspired to be, as 
a regenerating force in religion and politics, there can be little doubt that economically it was a devastating blight. ${ }^{32}$

The overthrow of the Taiping did not, however, mark the end of difficulties for the beleaguered Qing court. Other rebellious groups sprang up from the wake of the Taiping. One such secret organization called the Small Sword Society attacked and captured the Chinese walled city of Shanghai in $1853-4 .{ }^{33}$ The disruption to trade led the foreign powers to look at alternatives to Chinese administration of trade in the treaty ports. They sought some way of enforcing control over the existing Chinese customs system that was intrinsically corrupt and had been severely disrupted by the Taiping. The foreign powers wanted a say, preferably the biggest, in the taxes and duties imposed upon them.

A conference held at Shanghai on 29 June 1854, attended by the taotai of Shanghai and the British, American and French consuls, drew up the plans for a Western-style customs system. ${ }^{34}$ They envisaged a system in which there would be three Inspectors of Customs, one nominated by each of the British, American and French consuls respectively. From the outset it appeared the consuls had little real influence in the creation of the customs, as it was the taotai who appointed the Inspectors. This is deceptive as on further examination of the document it becomes clear that the consuls selected the appointees:

In the appointment of the head inspectors, and the organisation of the whole auxiliary department, it has been agreed as the best mode of guarding against any future difficulties and sources of complaint, and at the same time ensuring, by the better knowledge of persons, a proper selection, that the consular representative of each treaty power shall select and nominate, for appointment by the taoutae, one inspector. ${ }^{35}$

In this way, the consuls controlled the most significant process in establishing the new Customs administration; the taotai's role was a token one. This new institution was regarded with a certain amount of consternation among foreign traders; they believed it was unfair that only Shanghai had such strict customs procedures. It was envisaged, however, that if this system in Shanghai were successful, it could then be extended to the other ports in due course.

In early 1859 the Imperial Commissioner for Foreign Affairs at Shanghai appointed Horatio Nelson Lay, former British Vice Consul and interpreter, as IG of Customs. Lay travelled to each of the treaty ports with the objective of establishing a standardized Customs system throughout China, based on the Customs system in Shanghai operating in each of these ports. The customs system was extended to Guangzhou in October of the same year. ${ }^{36}$ It was at this time that Robert Hart resigned his consular post and embarked on what was to become a distinguished career in the 


\section{Introduction}

Customs Service. Hart took up the position of Assistant Commissioner at Guangzhou. ${ }^{37}$ The suitability of this Customs service having been proven in Shanghai, the push for the expansion of this system rapidly followed the Treaty of Tianjin (1858) and the opening of more ports to foreign traders; these were followed by further extension of customs control. Table 1.1 illustrates the manner in which Customs houses were established after the ports had been opened to foreign trade for a few years.

Table 1.1 The opening of treaty ports and Customs houses

\begin{tabular}{|c|c|c|}
\hline $\begin{array}{l}\text { Year opened as } \\
\text { treaty port }\end{array}$ & Place & $\begin{array}{l}\text { Customs } \\
\text { established }\end{array}$ \\
\hline 1842 & $\begin{array}{l}\text { Shanghai } \\
\text { Ningbo } \\
\text { Fuzhou } \\
\text { Xiamen } \\
\text { Guangdong }\end{array}$ & $\begin{array}{l}1854^{\mathrm{a}} \\
1861 \\
1861 \\
1862 \\
1859\end{array}$ \\
\hline 1858 & $\begin{array}{l}\text { Niuzhuang } \\
\text { Zhifu } \\
\text { Zhenjiang } \\
\text { Shantou } \\
\text { Qiongzhou } \\
\text { Nanjing }^{\mathrm{c}}\end{array}$ & $\begin{array}{l}1864 \\
1863 \\
1861 \\
1860 \\
1876 \\
1899\end{array}$ \\
\hline 1860 & Tianjin & 1861 \\
\hline 1861 & $\begin{array}{l}\text { Hankou } \\
\text { Jiujiang }\end{array}$ & $\begin{array}{l}1862 \\
1861\end{array}$ \\
\hline 1876 & $\begin{array}{l}\text { Yichang } \\
\text { Wuhu } \\
\text { Wenzhou } \\
\text { Beihai }\end{array}$ & $\begin{array}{l}1877 \\
1877 \\
1877 \\
1877\end{array}$ \\
\hline 1887 & $\begin{array}{l}\text { Longzhou }^{\mathrm{d}} \\
\text { Mengzi }^{\mathrm{e}}\end{array}$ & $\begin{array}{l}1889 \\
1889\end{array}$ \\
\hline 1890 & Chongqing $^{\mathrm{f}}$ & 1890 \\
\hline 1896 & $\begin{array}{l}\text { Shashi } \\
\text { Suzhou } \\
\text { Hangzhou } \\
\text { Simaog }\end{array}$ & $\begin{array}{l}1896 \\
1896 \\
1896 \\
1896\end{array}$ \\
\hline 1897 & $\begin{array}{l}\text { Sanshui } \\
\text { Wuzhou } \\
\text { Tengyue } \\
\text { (today Tengchong) }\end{array}$ & $\begin{array}{l}1897 \\
1897 \\
1900\end{array}$ \\
\hline 1902 & Jiangmen $^{\mathrm{i}}$ & 1904 \\
\hline 1903 & $\begin{array}{l}\text { Changsha }{ }^{\mathrm{j}} \\
\text { Moukden }^{\mathrm{k}}\end{array}$ & $\begin{array}{l}1904 \\
1907\end{array}$ \\
\hline
\end{tabular}


Table 1.1 continued

\begin{tabular}{|c|c|c|}
\hline $\begin{array}{l}\text { Year opened as } \\
\text { treaty port }\end{array}$ & Place & $\begin{array}{l}\text { Customs } \\
\text { established }\end{array}$ \\
\hline & $\begin{array}{l}\text { Andong }{ }^{1} \\
\text { Dadonggou }^{\mathrm{m}}\end{array}$ & $\begin{array}{l}1907 \\
1907\end{array}$ \\
\hline 1907 & Manzhouli & 1907 \\
\hline $\begin{array}{l}\text { Opened in } 1907 \text { by treaty } \\
\text { but styled 'self-opened' } \\
\text { in Japanese Treaty }\end{array}$ & $\begin{array}{l}\text { Hailar/Hailaer } \\
\text { Qiqihar } \\
\text { Aihui } \\
\text { Harbin } \\
\text { Kuanchengzi-Changchun } \\
\text { Jilin } \\
\text { Ningguta } \\
\text { Huichun } \\
\text { Sanxing } \\
\text { Xinmintun } \\
\text { Tieling } \\
\text { Tongjiangzi } \\
\text { Fakumen } \\
\text { Fenghuangcheng } \\
\text { Liaoyang }\end{array}$ & \\
\hline \multicolumn{3}{|l|}{ 'Self-opened' places } \\
\hline 1898 & $\begin{array}{l}\text { Qinhuangdao } \\
\text { Yuezhou } \\
\text { Sanduao } \\
\text { Wusong }\end{array}$ & $\begin{array}{l}1902 \\
1898 \\
1899\end{array}$ \\
\hline 1905 & $\begin{array}{l}\text { Jinan } \\
\text { Zhoucun } \\
\text { Weifang }\end{array}$ & \\
\hline 1907 & Nanning & 1907 \\
\hline
\end{tabular}

Source: Adapted from 'List of Treaty Ports, Etc., in Chronological Order' in Robert E. Bredon, circular no. 1501 (second series), Documents, vol. 2 646-8.

a The first IG was appointed in 1859.

b While officially opened in 1858, Niuzhuang wasn't opened to trade until 1864 .

c Nanjing was not opened until 1899.

d Not opened until 1889.

e Not opened until 1889.

f Not opened until 1891.

g Opened in 1897.

h Opened in 1900.

i Jiangmen was not opened until 1904. At this time another 10 outposts were established 1904 as West River passenger stations.

j Opened in 1904.

k Moukden was opened in 1907 but was styled 'self-opened' in American and Japanese treaties.

1 Andong was opened in 1907 but was styled 'self-opened' in American treaty.

m Dadonggou was opened in 1907 but styled 'self-opened' in American and Japanese treaties.

$\mathrm{n} \quad$ Wusong's status was modified from a port of call. 


\section{Introduction}

There was a flurry of Customs houses opening in the years following Lay's appointment as IG, with 11 outposts established between 1854 and 1863. From 1864 until 1876, however (when Hart was the newly appointed IG following Lay's fall from grace), few Customs houses were opened. This 12-year period was marked as one of consolidation for the new institution rather than further expansion. From 1877 this pattern of expansion and consolidation was repeated. Further development of Customs outposts was consistent from 1889 through to 1907.

Lay's leadership of the IMCS was short-lived. When on leave in London, the Chinese requested Lay's assistance to raise a flotilla to fight against the Taiping. This flotilla would then be used by the IMCS to combat piracy and smuggling. In doing so he overreached his authority. In an agreement signed in London in January 1863, Captain Sherard Osborn was appointed commander of the European-Chinese fleet for four years. As commander he was directly answerable to Lay, who nominated himself as acting on behalf of the Emperor. ${ }^{38}$ This agreement, moreover, emphasized that Lay held ultimate control for all orders given and that it was understood that Osborn would not accept instructions from any other channel. This included directives from the Emperor unless Lay conveyed them to his commander. ${ }^{39}$ Lay's manoeuvring for greater influence in Chinese affairs was unmistakable in the text of the agreement.

Lay's intention to wield power through this flotilla disquieted the Chinese leadership. In response to the contentious articles, negotiations were held between both Lay and Hart and the Chinese authorities. Prince Gong Qinwang communicated with Bruce:

As China would thus have spent several millions of revenue without obtaining an atom of power, his [Lay's] arguments (in support of the agreement) were rebutted, and in the place of it five other articles were drawn up. ${ }^{40}$

After a series of discussions in which Lay would not yield, he was dismissed from the service on 15 November $1863 .{ }^{41}$ Hart was immediately appointed IG. Lay was given a four-month period to settle the affairs of the Customs but was already removed from his post. ${ }^{42}$ It is noteworthy that the foreign powers did not get involved in this decision to remove Lay but respected the Qing court's right to dismiss him. ${ }^{43}$ Prince Gong welcomed Hart's appointment, warmly commenting that his prudence, tact and experience were well known to both Chinese and foreigners interested in the Customs. Nevertheless he issued a warning to him saying: 'it would behove you to be still more careful and diligent, so as to justify your present appointment. ${ }^{44}$ Clearly Hart would need to call all his skills for diplomacy into play as he proceeded to begin the creation of the IMCS that was to endure for the next 80 years. 


\section{Hart's vision for the IMCS}

True friend of the Chinese people

Modest, patient, sagacious and resolute

He overcame formidable obstacles and

Accomplished a work of great

Beneficence

For China and the world.

(So read the inscription on the plinth of the statue of Hart erected by a grateful foreign community on the Bund in Shanghai in $1914 .{ }^{45}$ ) Hart, considered the founder of the IMCS, was a giant figure, straddling both worlds of China and abroad. His papers have been painstakingly compiled, making it possible to assess not only his vision for the Customs Service but the role that he fulfilled as IG. ${ }^{46}$ Hart was personally responsible to the Zongli Yamen and the Chinese court for the efficient running of the service and hence often roved from port to port to ensure procedure was strictly adhered to. ${ }^{47}$ Under Hart's watchful guidance a regulated Customs service was fully established in China.

Hart's work as IG earned him the trust and admiration of Chinese Government, but in his career he amassed more personal power than the Chinese had ever envisaged when the IMCS was created. ${ }^{48}$ This can been seen most clearly in Hart's quasi-diplomatic role as intermediary between the foreign powers and the Chinese court. The Chinese often entrusted Hart with confidential tasks. Hart, in turn, would rely on a trusted colleague, James Duncan Campbell, and his London connections to assist with these duties. An example of this was in October 1874 when Hart was instructed to acquire a gunboat for the Chinese. ${ }^{49}$ By enlisting Hart's assistance with such delicate matters, the Chinese court showed that they trusted Hart's judgement, discretion and loyalty.

In an 1864 circular to all Commissioners, Hart outlined what he saw as the guiding principles by which the IMCS should be operating. ${ }^{50}$ This document is critical for understanding the aims and ambitions of the IMCS in its relationship with not only the Chinese but also the foreign powers. It inculcated the value of service, the importance of diplomacy and the necessity of integrity. In the circular's 24 points Hart detailed the various aspects of running the IMCS and what it should strive for in its status in Chinese affairs. This was written in response to failings and unsettling occurrences that Hart had noted during the first three years of the Service. Hart stressed the importance of Sino-Western relations for ensuring the smooth running of Customs establishments. He advised employees to remember that:

The Inspectorate of Customs is a Chinese and not a Foreign Service, and that, as such, it is the duty of each of its members to conduct 
himself towards Chinese, people as well as officials, in such a way to avoid all cause of offense and ill-feeling. ${ }^{51}$

Such comments were designed to encourage an acceptance of the foreign Inspectorate by the Chinese; this was vital to the longevity of the Service. Furthermore, if such advice had been followed, it would have ensured that the IMCS was on a more intimate footing with the Chinese than merchants and the foreign consuls.

Hart turned a considerable amount of attention to the Commissioners at the ports, seeing them as the vital element in ensuring the ports were running smoothly. In 1864 there were only 12 Commissioners but by 1912 this had increased to $40 .{ }^{52}$ They were reminded that they were not only responsible to the IG but also to the Chinese Superintendent of their port. They filled an advisory role with the Superintendent and were discouraged from trying to push themselves forward at the expense of the Chinese. Hart wrote: '[t] he more the Commissioners keep in the back-ground, the better will it be for the duties they have to perform, and the less will be the chances of their becoming objects of ill-feeling. ${ }^{53}$ Hart reasoned that it was not unusual for a Commissioner to have more knowledge of foreign trading practices than a Superintendent but imparting this knowledge needed discretion. Commissioners were also encouraged to keep good relations with consular staff and with the mercantile community. Hart urged staff to 'aim at the perfect' in fulfilling their duties. ${ }^{54}$ Clearly this document contains many of the key elements he wanted to see in the IMCS: loyalty to duty; a rapport with Chinese and foreigners alike; and willingness to improve their work.

Despite Hart's principles for the foreigners and Chinese to work together for the common good of the IMCS, the Chinese staff of the Service were not treated in an egalitarian manner (the Customs can be compared to the Indian Civil Service in this regard). ${ }^{55}$ Chinese employees did not fill any responsible positions within the elite indoor staff until after 1928 (owing to pressure from the Nationalist government). The 1895 and 1907 Service Lists of the Customs reveal that there was an increase in the overall number of staff, both foreign and Chinese. In 1895 there were 735 foreigners and 3,471 Chinese in the Service; by 1907 this had expanded to 1,387 foreigners and 12,389 Chinese. ${ }^{56}$ By 1912 there was roughly a ratio of seven Chinese staff to one foreigner. There is little discernible difference, however, in the level of positions held by Chinese. In both Service Lists Chinese staff were treated as a separate entity to foreign staff and rarely ranked higher than a clerk in the indoor staff. ${ }^{57}$ According to Wright, the role of these Chinese clerks initially was to act as go-betweens and translators for the foreign staff who were unable to speak Chinese. More important perhaps, Chinese clerks helped the Service cut its running expenses 'by entrusting the less important kind of routine office work to natives on moderate salaries' ${ }^{58}$ (such a hierarchy was not unusual in any British colony at this 
time). Apart from their superior ranking in the IMCS, foreign staff had a privileged position in the Service because, although they worked for the Chinese Government, they still enjoyed the right of extraterritoriality. This meant they were not answerable to Chinese law but would be tried by their own national court.

As with any imperial institution of the time, Hart discouraged his staff from the temptation of 'going native'. He reminded them that they were representatives 'of a civilization of a progressive kind' and accordingly should not hesitate to raise Chinese interests in this civilization. ${ }^{59} \mathrm{He}$ did stress though, that any such action must be placed after the commitment to work for the Chinese Government and that ideally they should lead through example. Such comments are not without a certain amount of irony. During his early years in China Hart had a Chinese common law wife and three children from this relationship. ${ }^{60}$ Hart's own indiscretions during his early career may have added impetus to his warnings for Customs employees.

In both his work and pastimes, Hart reflected high aspirations for his Service. Appearance was important for the IMCS and in Hart's voluminous letters to Campbell the idea of a uniform for the indoor staff was raised on several occasions. ${ }^{61}$ The main incentive for the creation of such uniforms was Hart's desire that staff could appear before Chinese officials in similar official dress and that, in doing so, they would also be recognizable by rank. ${ }^{62}$ In Hart's discussion of the uniform, one is given the impression that, while Western in basic style, it was intended to have a certain 'Chinese flavour'. He envisaged his staff sporting a French-style cap with a knob and tassels on top. ${ }^{63}$ The colour of the knob would determine rank: red for the IG, blue for Commissioners and Deputy Commissioners, and white for the clerks. In one description Hart enthused that the uniform should be 'diplomat style', providing an interesting reflection on the extent of powers that the Service possessed in directing Chinese actions and, importantly, the Customs' perception of itself. ${ }^{64}$ The role of foreign Customs staff as promoters of Western values and culture in China was evident through Hart's passion for music. The IMCS brass band, which Hart trained and nurtured during his spare time, is an example of these two principles in action. Through this band, which consisted almost solely of Chinese employees, Hart was advancing the ideals of Western culture. This places the IMCS within a grander, imperialist, civilizing mission of foreigners in Asia. ${ }^{65}$

Consular jealousies had been evident since the inception of the IMCS and did not abate with Hart's appointment as IG. The British were perceived to dominate the Service with their recruits. American representative Anson Burlingame complained in strong terms to Sir Frederick Bruce, British Minister to China, about this in 1900. Furthermore Burlingame reported to the US Secretary for State that he distrusted British intentions in the matter of dominating the IMCS and also their 'seeming control 


\section{Introduction}

of the Treaty Ports' ${ }^{66}$ The profile of senior staff in 1864 exemplified the grounds for suspicions of the British. The nationalities of the Commissioners were as follows: five British, three American, three French and one German; fuelling complaints of British predominance. ${ }^{67}$ In the early days of the IMCS, however, there appears an element of inevitability with regard to British prominence. Not only were the British leaders in Sino-Western relations, but they also possessed a larger number of men who had the essential Chinese language skills. The other treaty powers had little mechanism for usurping British position in the IMCS or its China relations. In spite of all this, the Service had quite a cosmopolitan staff and encouraged the learning of the Chinese language for all its young foreign recruits.

While there was a considerable amount of banter about Service integrity, the IMCS attracted its share of adventurers and opportunists. A.H. Rasmussen, who joined the outdoor staff in 1905, described the IMCS as the 'Foreign Legion of the Far East'. ${ }^{68}$ He commented:

There were men from every imaginable stratum of society: remittance men, drunks and sober men, gentlemen and rascals, ignorant and highly educated men. Love of adventure had attracted some of them to the Service; others were probably fugitives from justice, hiding under assumed names, and some like me, had joined from necessity ${ }^{69}$

Rasmussen's romanticized reflections give the impression that many men in the Service had pasts they may have wanted to avoid. Such reflection of the motley nature of the Customs employees may further explain Hart's issuing of circulars outlining the ideal spirit of the Service.

In a bid to prevent the Customs employees from developing close ties with, and therefore vested interests in any one port, Hart regularly rotated staff around to minimize these temptations. ${ }^{70} \mathrm{He}$ was also known to utilize the threat of transfer as a method of disciplining his employees. ${ }^{71}$ This system, however, was not always foolproof and staff indiscretion often caused Hart concern as any such breaches gave impetus to growing Chinese demands for the removal of foreigners from the Service. In a letter of 1869 he described one of his Commissioners as a 'quarrelsome, pigheaded fellow' who was a great clerk but a 'frightfully bad Commissioner' ${ }^{72}$ In another instance, a Deputy Commissioner had been expropriating Customs funds for his own benefit. ${ }^{73}$ Despite the good service the Customs was fulfilling for the Chinese Government, not all of Hart's employees adhered to such ideals.

Duties of the IMCS included application of customs tariff and collection of revenue, cargo appraisal, navigational aids (coastwise lights and charts) and the publication of trade statistics. ${ }^{74}$ With the absorption of the postal service into the IMCS in 1896, Hart became the IG of Customs and Posts. ${ }^{75}$ The number of staff required to administer these dual services rapidly 
increased. Part of the revenue collected covered the expenses of the Service. In fact, in the earliest years of the Customs existence, there was little revenue left over after covering the cost of maintaining the daily expenses of the Service. As revenue increased then foreign loans were serviced by the CMCS with surplus at the Chinese Government's discretion.

\section{The coming of the Republic: The end of a golden age}

The IMCS viewed the instability of the Qing court, besieged by internal corruption, Western imperialist pressures and social turmoil, with trepidation. A rise of Chinese nationalistic fervour fuelled these concerns. Hart pessimistically prophesied that:

The Customs will go on forever and the foreign element will be retained as long as it is useful, subordinate, and wanted, but Chinese supremacy will be felt and will grow in form and fact, and the foreigner will die out. ${ }^{76}$

While the foreigner did not 'die out' of the Service, the coming of the Republic, the decentralization of power and the rise the GMD with their anti-imperialist sentiment posed considerable threats to the fabric of the service.

The Boxer Rebellion of 1900 was a popular response to the frustration and resentment of foreign intrusion into China. The siege of Beijing and the loss of foreign lives and property left the Western powers shaken by the enormity of Chinese popular resistance. In the ensuing Peace Protocol of 1901, the treaty powers claimed reparations for their losses. These indemnities were secured against the customs revenue after paying for the upkeep of the Service itself. Tariffs were set at 5 per cent ad valorem. This setting of tariffs guaranteed the Service revenue but at the same time benefited traders and disadvantaged the Chinese Government, as they were unable to adjust these tariffs over time. ${ }^{77}$ The return of tariff autonomy became a major platform for the GMD and its nationalist movement.

The revolution of 1911 had far-reaching significance on the Customs Service. The Chinese Imperial Post Office, which had been created under the Customs auspices in 1896, became an independent service this year. ${ }^{78}$ The largest change, however, was to the leadership of the Service. Physically and mentally exhausted after many years of unstinting service, Hart travelled to London on leave in 1908 and Francis Aglen, his deputy, was placed in charge. Hart never returned to China but he retained the official title of IG of Customs until his death on 20 September 1911.79 Hart's legendary efforts were memorialized through the erection of a statue on Shanghai's prestigious waterfront location, the Bund, in $1914 .{ }^{80}$ At the official unveiling ceremony, Customs officials and consular staff were among those who paid tribute to Hart's distinguished China career. 
The succession of Hart's leadership by Officiating IG Francis Aglen ${ }^{81}$ had not been without its share of dilemmas. For many years Hart's brotherin-law, Robert Bredon, had waited anxiously in the wings for his appointment, only to be thwarted by Hart's reluctance to relinquish his post and by dislike on the part of British authorities (and if the truth be known, by Hart as well). ${ }^{82}$ The post of IG was clearly considered one of great significance and changes to leadership caused considerable angst during their transitional phases. Succession-related turmoil commonly occurred throughout the history of the Service and the top post of IG was inevitably the focus of much jockeying for position.

The First World War had a lasting impact on the Customs Service. The Service was seriously depleted of staff who left to enlist to fight the war in Europe. Aglen instructed the CMCS that neutrality rules were to be enforced, owing to the fact that China had declared itself neutral in the conflict. Staff who wished to return to take up arms were instructed to tender their resignation with the Service. There was a possibility of reemployment, however, in the event they later returned to China.$^{83}$ Reflecting upon this King (the NRS, London) commented:

I could not help but see that the wholesale exodus of young men from their jobs in China was a tactical mistake. ... 'They also serve who only stand and wait,' and the negligible quantity - from the numerical point of view - of British youths, who left their jobs in China and Japan, did more than 'their bit' - though they could not see it in that light - towards weakening British grip on Far Eastern trade. ${ }^{84}$

Clearly, the perception held here was that it was vital for the British to maintain its dominance in trade with China. In reality, the Japanese, whose trade with China continued to grow, were rapidly outstripping that of the British. As Shanghai was the most economically vibrant of the treaty ports it is valuable to examine reports of trade according to nationality from the 1912-21 series of Decennial reports. ${ }^{85}$ British trade represented 54.8 per cent of annual revenue in 1912, (America 0.8 per cent. France 2.8 per cent, Germany 8.1 per cent, Japan 19.4 per cent, Chinese 9.1 per cent and Miscellaneous 5 per cent). In the war years the most striking difference is the British and Japanese results. In 1918 Britain represented 31 per cent and the Japanese increased to 45.5 per cent. After the war British percentages rose again to 47 per cent in 1921 and the Japanese declined to 29 per cent. This indicates the opportunities the Japanese were able to make during the war years, no doubt increasing King's conviction that as a matter of strategy Western staff needed to remain in the CMCS.

In the years following the 1911 revolution, the political situation in China was significantly disturbed and there were concerns over the fate of the Customs revenue. As a result revenues were placed in the respective Commissioners' hands as the imperial officials had fled from their posts. 
The IG then assumed responsibility for these revenues. A loans and indemnity service was then administered from Shanghai ${ }^{86}$ Hence, until well into the 1920s revenue surplus was directed into foreign banks. This was justified in the CMCS as protecting revenue but was importantly a guarantee that foreign indemnities and loans would be serviced. The three banks designated for this appropriation were the Russo-Asiatic Bank, the Deutsch-Asiatische Bank and the Hong Kong and Shanghai Banking Corporation. Due to faltering international relations in the case of the German bank and national crisis in the case of the Russian bank, all revenue was placed in the Hong Kong and Shanghai Bank, a British-owned financial institution. ${ }^{87}$ This further accentuated the extensive dominance the British played in the foreign inspectorate of the CMCS.

During Yuan Shikai's tenure as the first President of the Chinese Republic, he kept rivalries and ambitions in check and subservient to his regime. His death in 1916 was a catalyst for the visible decentralization of political and military power, and many of these rivalries broke to the surface of the new government. Factionalism occurred as in many instances Yuan's former protégés sought to strengthen their control and power base. This led to a rapid decentralization of power in China, with rival forces gathering provincial power bases in a bid to assert their dominance and to claim national sovereignty. The phenomenon of warlordism had emerged in China and would bring chaos for over a decade. For the warlords, the potential revenue offered by the Service would have been a tantalizing prospect, should they be successful in establishing the dominance of their own regime. And, for the CMCS, the integrity of the institution was vital for its continued survival.

The chaos of the early Republic foretold the beginning of what would become an ongoing process of change for the Service. For the Chinese the CMCS became the focus of resentment as it allowed a foreign mechanism for exerting influence. The desire for tariff autonomy and control over surplus revenue were platforms adopted by Chinese nationalists in their campaigns to free China from foreign imperialist interests. The Nanjing Government's plans for a strong, united China did not have room for such a Western-dominated service. Hence the 1920s, 1930s and 1940s provide a fascinating study of the Service and its attempts to negotiate its place within such a rapidly changing political climate. 


\section{An institutional review}

Throughout its history the CMCS was described in various institutional terms. It was regarded as the basis of the Chinese economy, and was presented by its contemporaries as the closest model to a civil service in modern China. This chapter examines the Customs in these terms, namely as a bureaucracy and fiscal organization. This chapter is divided into four sections, each providing a perspective on this institution. These include an examination of the structures of the CMCS; an economic review of the Service and its significance to both the Chinese and foreign interests; an exploration of the London Office (LO) of the Customs and its unique role in perpetuating and protecting foreign interests in the Service; and an exploration of the privileged life led by foreigners in the Service. Consequently, this chapter provides the backdrop for understanding the rationale and motivations of the Service and its responses to events in the 1920s and 1930s.

\section{The structures of the Customs Service}

During the early Republic, the CMCS possessed three major divisions: a Revenue Department, a Marine Department and a Works Department. A later addition was the Preventive Department, established in 1931 in response to widespread smuggling on the China coast. Despite the expansive scope of the CMCS, it remained extremely centralized as an organization. Control for the direction of the Service rested solely in the hands of the Inspector General (IG). In theory the IG was answerable to the Chinese Government, but for the early part of the Republic (1912-26) this was not evident in the leadership of Aglen and only became a more conscious action by Maze (IG from 1929 to 1943).

The structure of the CMCS was complex, as would be expected from an institution that combined a national service with a wide-ranging scope of duties. ${ }^{1}$ Moreover, the CMCS, while appearing unified, had two major structural schisms. These were the division between foreign and Chinese staff and also the divide between indoor and outdoor staff. A schematic representation of the various departments in the Service gives some idea 
of the scale of this organization. The IG was at the top of the Service with his Commissioners forming the important basis for the dissemination of orders and the daily running of the ports (see Figure 2.1).

Commissioners filled a centripetal role in the functioning of the Service. They were immediately under the IG in terms of seniority in the Service as well as in the flow of command. The Secretaries appointed to various departments under the IG were of, and shared, Commissioner ranking. The Commissioners employed at Customs houses did not merely act as overseers of Inspectorate instructions, but were the vehicles through which information and directives were disseminated to staff. Essentially the Commissioners acted as the IG's representatives and the local chiefs. They were the vital link that maintained the unity of the Service through the management of the Customs ports and their loyalty to the Service and, most importantly, to the IG. In matters concerning revenue, the Superintendent of Customs (a Chinese) was consulted. In matters pertaining to the recruitment, training, promotion of and/or disciplining of staff, the Commissioner was obliged to defer to the IG's authority.

Appointment to the position of Commissioner was generally the culmination of around 20 years' service (see Table 2.1). This table provides an indication of the length of service generally undertaken by customs staff before they can reach the level of Commissioner. The one notable exception in this table is that of Maze (Hart's nephew), who became IG in 1929. Maze had only been in the Service for nine years before his appointment as Commissioner. Prospective Commissioners were appointed from the indoor staff. Ports, however, varied in size and therefore had differing significance to the Customs. Newer Commissioners were generally appointed to the smaller establishments to gain some experience before being entrusted with the running of the larger ports. Smaller ports included postings to Longzhou, Mengzi, Wenzhou and Yadong, for example. ${ }^{2}$ And, in a reflection on the importance of certain ports, senior Commissioners administered Shanghai, Tianjin and Guangzhou. ${ }^{3}$

Responsibilities were clearly demarcated within each Customs house. The collection of tariffs and duties flowed from the Commissioner in each Customs house to the Inspectorate. To facilitate trade, Marine staff manned Customs Cruisers and assisted with navigational and conservancy work. The outdoor staff examined cargoes and prevented smuggling by searching vessels. The indoor staff examined traders' paperwork and assessed and collected the tariffs due. They administered and kept record of the import and export trade of the ports. ${ }^{4}$ The Commissioner oversaw the collection of tariffs within his Customs establishment. After settling pre-agreed accounts for the running of the Service and sundry expenses, the net revenue was forwarded to the IG's account in Shanghai. Funds were remitted on a weekly basis at the larger ports and generally twice monthly for smaller ports. ${ }^{5}$ This tight reign over accounts reinforces the highly centralized structure of the Service. Any problems or discrepancies 


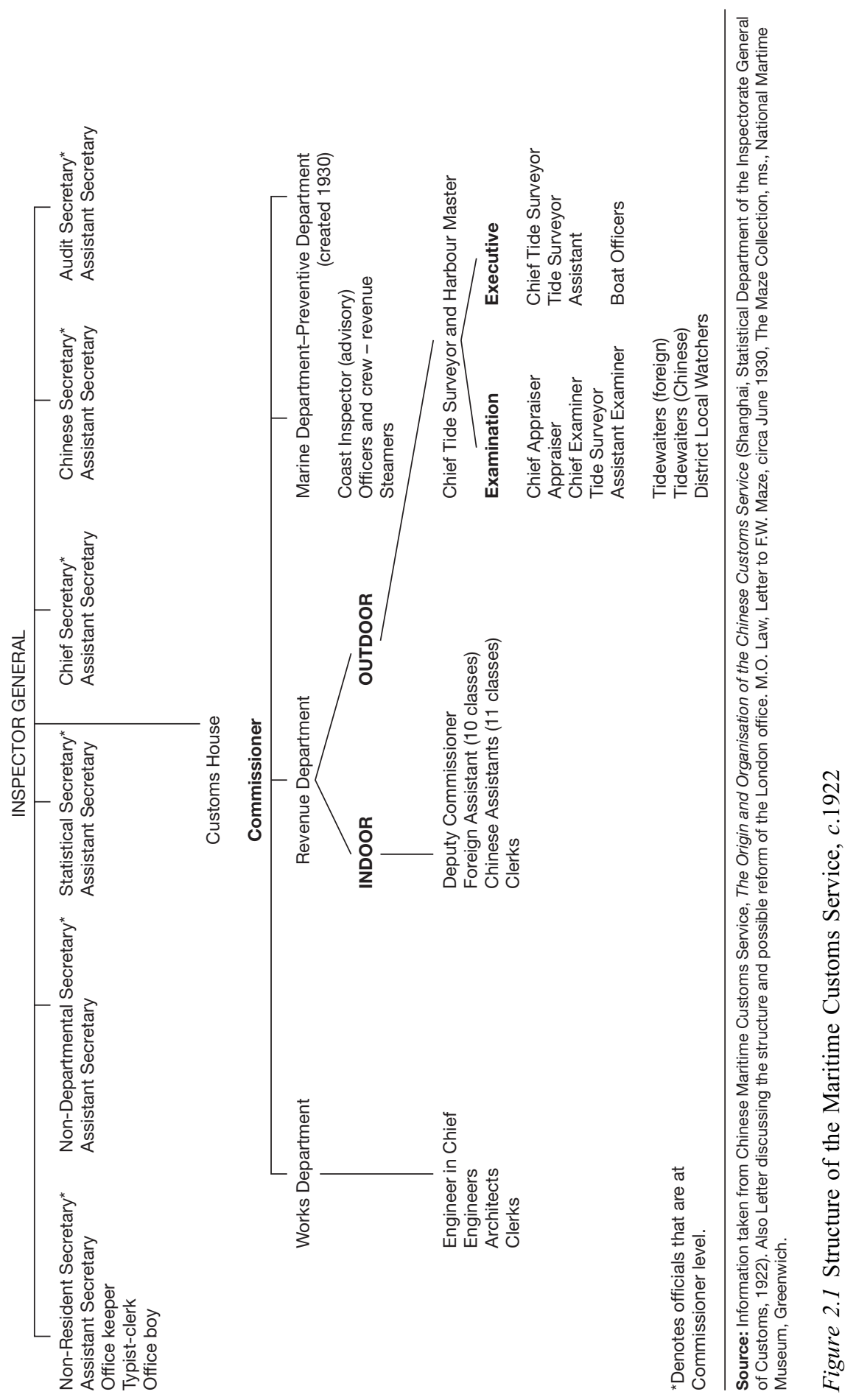


Table 2.1 Selected Customs Commissioners of 1911

\begin{tabular}{llll}
\hline Name & Nationality & $\begin{array}{l}\text { Date of first } \\
\text { appointment }\end{array}$ & $\begin{array}{l}\text { Date of } \\
\text { appointment to } \\
\text { Commissioner }\end{array}$ \\
\hline H.M. Hillier & British & August 1872 & April 1896 \\
P.H. King & British & January 1874 & April 1900 \\
C.A.V. Bowra & British & October 1886 & March 1903 \\
F.W. Maze & British & January 1897 & November 1906 \\
A.H. Harris & British & July 1883 & September 1908 \\
J.H. Macoun & British & May 1888 & March 1910 \\
J. Acheson & British & July 1874 & April 1911 \\
\hline
\end{tabular}

Source: Chinese Maritime Customs Service, Service List, 1911-1913 (Shanghai: Statistical Department of the Inspector General of Customs, 1914).

occurring in the accounts could be detected rapidly and redressed. Furthermore the regular removal of funds to the Inspectorate reduced the possibility of demands being made against the funds accumulating at any one Customs house.

The indoor staff formed the elite of the CMCS. The essential difference between indoor and outdoor staff being that the former underwent a thorough examination and vetting process before taking up a China appointment, while the latter were more likely to be drawn from the pool of foreigners living in or travelling through the treaty ports. ${ }^{6}$ They enjoyed a much more exclusive existence and better benefits than the outdoor staff, which will be elaborated later in this chapter. A sense of superiority emerged from the fact that they were removed from the physically arduous tasks of examining cargo. Yvonne King, whose father and husband both had CMCS careers (indoor staff) reflected:

The outdoor staff were the people who actually met the ships and went through your luggage and when the big ships brought in cargo the outdoor staff went on board and did the actual sorting of the cargo. The indoor staff were purely in the office ... unless there was some special occasion or something and then they may have gone and boarded a ship. ${ }^{7}$

In her recollections King spoke freely of there being a sense of snobbery on the part of the indoor staff towards their outdoor counterparts. The two groups of staff had their own distinct social circles and generally did not intermix. ${ }^{8}$ Attention to redressing this disparity is discussed even during the IMCS period in the letters of G.E. Morrison 'Morrison of Peking. ${ }^{9}$ In 1917 Morrison wrote that if any Chinese institution needed reform it was the Customs administration "with its excessive pay of the indoor staff and 
the wholly inadequate pay of the outdoor staff' ${ }^{10}$ Through readings of the Customs documents in the 1920s and 1930s, it is apparent that even the lowest position in the indoor staff was a more esteemed appointment than that of those relegated to the arduous outdoor examination and assessment of goods on the docks and in the godowns.

Rasmussen's China Trader provides an interesting insight into the experiences of a member of the outdoor staff of the Customs. Foreign outdoor staff were generally drawn from sailors and adventurers who had been lured to the East. Rasmussen, himself a sailor, had arrived in Shanghai in 1905 with only \$5 (10s.) and was reassured by acquaintances that he would have no difficulty gaining employment in the IMCS. ${ }^{11}$ While relieved at his appointment as a probationary tidewaiter, Rasmussen was conscious of the low status of outdoor staff. He wrote:

My elation was not in the slightest dampened by the fact that I had put my foot on the very lowest rung of the social ladder. Caste among the Europeans was a reality that no one could escape and the outdoor staff in the Customs were almost like the untouchables in India, and nearly as low as the Eurasians. The indoor staff in the administrative offices were, on the other hand, very high on the social scale. Fortunately, an ex-sailor has few, if any, social aspirations, and I had none. ${ }^{12}$

While this account may be exaggerated for literary effect, the humble position of outdoor staff in the Service clearly contrasts with that of the indoor staff. In a further illustration of this disparity between the indoor and outdoor staff, Williams, a Customs Commissioner, includes in his memoirs an excerpt from the treaty port press, the Shanghai Mercury, outlining a humorous account of the day in the life of an Assistant Examiner. ${ }^{13}$ This account makes a successful satire of the underlying tensions between the overworked and underpaid outdoor staff shouldering dirty and sometimes monotonous assessment responsibilities in contrast to their sheltered and comfortable indoor counterparts.

The disparity between Chinese and foreign staff was also noticeable in the CMCS. It was not until 1929 that the idea that Chinese could fill equal posts to foreigners gained any currency. This was due to a combination of factors: the new leadership of IG Maze, who was sympathetic to Nationalist aspirations, and the directives of the GMD to see the end of foreign staff in the Service. ${ }^{14}$ Rivalry also existed between the various nationals represented in the Service. Williams recalled being disgruntled when made joint charge of the general office at Jiujiang, a small port on the Yangzi. His Commissioner was a German and had been most disappointed not to receive a German assistant, who he believed would have been more efficient than any Briton. Williams bore the brunt of this dissatisfaction and, as he details, '[the Commissioner] put me in joint charge of the general office with a Chinese clerk - an indignity which 
I think it would be hard to beat!' ${ }^{15}$. Williams' mortification was on two counts: first, that he had previously been in charge of a general office and therefore was being compelled to take a backward step; and second, that he was made to work alongside a Chinese clerk.

\section{Regulating and rewarding staff}

Commissioners were entrusted with the responsibility of ensuring that staff were adequately trained. In a customs circular of 1924 IG Aglen stressed that it was important that indoor staff regularly changed responsibilities around the office to ensure they developed the necessary administrative skills for all aspects of their work. This cultivation of versatility, he reasoned, would enable staff to fill vacant posts with a minimum of disruption:

I consider it a grave reflection on Commissioners when they are compelled to report - as is much too often the case in the last Confidential Reports to hand - that such and such a man 'has not performed' (several classes of duties) 'at this port' after a stay of several years there. $^{16}$

Aglen encouraged Commissioners to inspect their subordinates' work regularly and to set examinations for them, in a bid to ensure that they understood the principles on which they were operating. He emphasized that this principle should be applied even more so to the Chinese indoor staff as they were moved between ports much less frequently than their foreign counterparts and therefore did not have as many opportunities. ${ }^{17}$

As part of their employment, all foreign Assistants were expected to learn the Chinese language. To encourage this, each Assistant, during his first six years, was given an allowance of $\$ 10$ per month to employ a native teacher. Examinations were administered regularly to monitor progress. There were three certificates, A, B and C, set at varying points in the Assistant's career (C: three years in China; B: not later than five years; and A: optional). Results in these determined the rate of promotion. Assistants who made little effort to learn Chinese were dismissed. Similarly those who had not progressed were liable to have their promotions withheld. It was envisaged that all Assistants would attempt Certificate A, although it was optional. Only Assistants who held Certificate A were considered for the rank of Deputy Commissioner or Commissioner. Williams, who like many employees devoted much time to the study of Chinese did not, however, believe that it greatly benefited his upward mobility in the Service. ${ }^{18}$ He recorded a dinner conversation that revealed uneasiness within Customs circles that learning Chinese would affect one's mental balance:

At a dinner-party given by one of my colleagues, his wife remarked to me: 'My husband never studies Chinese. He says people who study 
Chinese invariably go mad!' Then, hastening to cover up her faux pas, she added: 'Of course, you are an exception to the general rule!'19

Williams claims to have known one Customs employee who, in a bid to improve his Chinese skills, had pasted Chinese characters all over the walls of his bedroom and 'lived in a continual atmosphere of complicated brushwork' ${ }^{20} \mathrm{He}$ went mad and had to be invalided home. On the way back to England this fellow refused to speak anything but Chinese; furthermore, he refused to bathe as he explained the Chinese rarely did. ${ }^{21}$ While knowledge of the Chinese language could lead to promotion, employees had to take care not to go native.

Outdoor staff also came under scrutiny from the Commissioner. Aglen encouraged all Commissioners to inspect their work regularly. $\mathrm{He}$ instructed:

Periodical visits should be paid to the wharves, jetties, godowns, and other places where Examiners work; books, samples, etc., inspected, methods of examination investigated, advice given, criticism or censure administered where slackness or bad work is revealed. ${ }^{22}$

In the larger ports, however, the Deputy Commissioner or another senior employee handled these inspections. By continually regulating staff Aglen believed any problem employees could be identified with reasonable speed and then either be cautioned or dismissed. The Commissioner or senior staff recorded their inspections in detailed confidential reports on each employee ${ }^{23}$ After the Commissioner's approval these reports were submitted annually to the Inspectorate each December. The reports provided the Inspectorate with an indication of each man's ability, character and his qualifications. Employees' work abilities were scrutinized alongside personal traits such as trustworthiness, industriousness, intelligence, discretion, temperament and manners. A general scale of reference regulated all reports; in this way a comparison of staff performance could be made more accurately. Decisions on transfers and promotions were made on the basis of these reports. In the case of an unfavourable report the employee was notified and given the opportunity either to amend their actions or to answer any allegations.

With staff hired from such a diverse and broad base, the CMCS had to maintain a strict code of conduct. Corruption was a continual concern for the Service and from Hart's time onwards there were instances where dishonest staff were dismissed. One problem among the outdoor staff was that foreigners were recruited from varied backgrounds and often held sympathies with traders and smugglers. Rasmussen gives an example of these conflicting loyalties. He explains that, while at Zhenjiang, he often went out on preventive patrols at night as he was tempted by the rewards given to those who uncovered salt smuggler activities and also by the lure 
of adventure. ${ }^{24}$ Other staff would turn a blind eye to salt smuggling, as they didn't want to risk their personal safety. Rasmussen recounted the thrill in pulling up alongside seagoing junks and jumping on board:

They were mostly trading junks with their papers in order, and if they did carry a moderate amount of smuggled stuff occasionally I let them keep it. The sailor in me was still very much alive, and I had a sneaking regard for people who had the good sense and decency to give their ships eyes to see with. It was for this reason I often closed my own to many irregularities. ${ }^{25}$

Thus staff sometimes interpreted Customs regulations to suit their own purposes. Rasmussen's patrolling for smugglers was more to alleviate his boredom than to see Customs regulations carried out. Staff sympathies with smugglers and also their reluctance to antagonize these organized groups constituted an ongoing concern for the CMCS.

The CMCS code of conduct also covered non-Service activities. Consequently staff were "not allowed to engage in trade or to interest themselves either directly or indirectly in the importation or exportation of merchandise' ${ }^{26}$ Furthermore, they were forbidden to receive any remuneration for services without the IG's written permission. They were also required to abstain from expressing political views or criticism in public. ${ }^{27}$ Particular offences that would leave an employee liable for dismissal included collusion with customs brokers, absence without leave, malversation and gross immorality. Offences leading to suspension and investigation included negligence, lack of respect for superiors and the criticism of superiors or government matters in the public press or in addresses. ${ }^{28}$ The Commissioner was responsible for the censure or suspension of staff guilty of, or charged with, misconduct. ${ }^{29}$ Any such action, however, became the subject of a report and the more serious cases were referred to the IG.

Problems of corruption were not only isolated to the ranks of the outdoor staff. Indoor staff were regularly transferred from port to port in a bid to prevent them from forging any ties with local merchants or foreign traders. Neutrality and aloofness from the business world was the ideal. Yvonne King recalled instances where both her father and husband received lavish gifts (including jewellery, chinaware, flowers and fruit) but that these were always returned (much to her dismay when as a child she saw fruit and delicacies normally unobtainable in China) as there was a consciousness that they did not want to become indebted to anyone. ${ }^{30}$ Such gifts could have tempted indoor staff to enter networks of favours or guanxi (relationships) with Chinese merchants. ${ }^{31}$ Such a culture of indebtedness would have seriously compromised the position of CMCS staff.

In a contrast to its punitive mechanisms, there was a detailed system for rewarding meritorious or loyal duty. Two awards are mentioned in the guide to staff organization and control, those of the Financial Medal and 
the Chinese Customs Medal for Meritorious Service. ${ }^{32}$ They awarded the Financial Medal to staff who had made contributions to the financial affairs of the Chinese Government. It was open to any employee from the finance department but also to others who had made a contribution to the government's financial dealings. It was awarded to staff who had, for example, served meritoriously for more than five years, or authored special financial publications, or were responsible for discovering a case of smuggling that resulted in a seizure of goods valued at more than $\$ 10,000 .{ }^{33}$ There were nine divisions of Financial Medals: 1st Class (three grades), 2nd Class (three grades) and 3rd Class (three grades). The Medal for Meritorious Service was designed as recognition of staff who had served 25 years of continuous and distinguished service. It had three grades - Gold, Silver and Bronze - and these medals were conferred by the Ministry of Finance at the recommendation of the IG.

\section{Financing the Republic}

As a well-organized fiscal institution, the CMCS was an invaluable source of revenue for the Chinese Government. With its immense revenue potential, the Service was intimately tied to the general financial health of the Republic. By the 1920s and 1930s, not only was the CMCS an important revenue source but it also provided a security against which internal and foreign loans could be issued. The following section provides an exploration of the role of the CMCS in the finance of the Republic.

The CMCS served two key economic purposes. It assisted in the regulating of trade to benefit both Chinese authorities and Western traders and also provided the Chinese Government with a regular source of revenue. In many Customs documents of the 1920s and 1930s a continual rhetoric emerges, one that reinforced the image of the Customs as a prolific source of revenue for China. Aglen often reflected on the evolution of the Service during his leadership. The development of the Service as a major revenue source was, in Aglen's perception, closely linked to the finances of the Chinese Government and also foreign interests in China. He outlined:

It seems to me that the Service has gone through two stages and is on the eve of a third. At first it was a purely Chinese institution maintained and supported by the Government because we supplied a certain income which the Gov. [sic] found very useful. Then the loans came and we became a foreign interest with the Chinese Gov.'s interest still predominant: the Indemnity gave the foreign Governments a financial interest in us; the revolution which gave us control of revenue and loan service, transformed us into an unofficial foreign Caisse de la dette, a position full of anomalies, but on the whole suitable to the times.... The last stage in this development has been reached owing to the virtual cessation of central Gov. authority and the necessity of 
carrying on administration with borrowed money. The Customs is now an imperium in imperio ${ }^{34}$ practically independent in matters of Government finance but in the last resort asking not rather Chinese Gov. but on this foreign powers. ${ }^{35}$

Further to this Aglen cited the Boxer indemnity and other foreign loans between the Qing court and the foreign powers that were secured against the Customs as evidence of this independence. He also touched on the development during post-revolutionary turmoil where, after 1917, Custom revenue was placed into foreign banks and only after loan and indemnity payments were met did the Chinese Government receive any surplus. By the 1920s the Hong Kong and Shanghai Banking Corporation was the sole custodian of the Customs account. ${ }^{36}$ Aglen's comments highlight the interdependency between the Chinese, the CMCS and Western interests in China.

Literature on the Nationalist era presents a widely divergent picture of the Nationalists' attempts at handling the Chinese economy, and, while not necessarily agreeing as to whether the Nationalists were a success or an outright failure, the existence of a deficit problem, fuelled throughout the Nanjing decade, is widely recognized. In his work, The Government and Politics in Kuomintang China 1923-1937, Tien examined the institutional developments (or in many instances the lack thereof) implemented by the GMD government during the Nanjing decade. In the course of this study, Tien draws attention to the deficit of the government as it channelled funds into its military and debt service. ${ }^{37}$ Preceding Tien's work, Pauuw's article, 'The Kuomintang and Economic Stagnation, 1928-37', discusses the deficit of the government and its focus on the military as a means for achieving tangible unification of China. ${ }^{38}$ Research by Rawski, Endicott, Wright and Osterhammel also contributes to the picture of Nationalist China as a financially tenuous period compounded by internal dissension and world depression. ${ }^{39}$ The budgetary reports referred to in the following pages illustrate the scope of China's financial dilemmas. Receipts for each year were heavily bolstered by loans, this in itself being the contributing factor towards the government's deficit problems.

The foreign powers had a vested interest in the development and progress of the Nationalist Government. During the Republic British officials and merchants continued to cling, albeit naively, to the dream of China's unlimited market that, one day, might be opened ${ }^{40}$ For their investments to develop, however, they needed a relatively stable environment; something that Jiang Jieshi's government appeared to promise once it was in power. The CMCS represented a key element in this financial stability. In the China Year Book $(C Y B)$ of 1931, there is a commitment on the part of the Nationalists to strive for greater stability of their economy and the financial rehabilitation of the nation. The financial report reads: 
Foreign lenders will not seriously discuss loans to China unless China has balanced its budget, or has adopted and is carrying into effect a programme of readjustment which will result in stabilizing the finances within a reasonable time. ${ }^{41}$

Further to this Song Ziwen (better known as T.V. Soong), the Finance Minister, warned that, while loan projects were receiving popular attention, they would take considerable time to bring to fruition, even though at the outset they might have appeared 'within the realm of practical finance'. ${ }^{42}$ The overwhelming message in such comments was the recognition that there was no easy solution to China's budgetary problems.

The foreign powers wanted to ensure the repayment of their loans and indemnities and this encouraged intervention in China's finances. The loan consortium that emerged just after 1911 and existed throughout the Republic is a prime example of foreign involvement in China's finances. This consortium, consisting of representatives of Britain, Germany, France and America, was created to avoid inter-rivalry between the principal lending groups to China and to present a united front to the Chinese treasury. This group had British Foreign Office backing from the outset and was closely allied with political ambitions. As Kann shrewdly observed, 'as a matter of fact politics became closely intermixed with finance' ${ }^{43}$ One avenue through which Britain could ensure its interests were protected was the CMCS. The Service represented a vital security for foreign loans to China. ${ }^{44}$

Financial reports were submitted to the $C Y B$ by the Minister of Finance but were not always issued or received promptly. The $C Y B$ for the 1923-37 period regularly devoted a chapter to the financial situation of China. The material contained in these chapters often consists of a proposed budget (in the years prior to the Nationalists' ascension to government) and/or a financial statement of revenue and expenditure for the previous fiscal year (1 July-30 June). A commentary by a Western 'expert' or observer accompanied such reports. In some instances Customs reports and government reports as to revenue do not necessarily correspond. This can be largely attributed to the fact that figures were compiled separately by the Ministry of Finance and by the CMCS' Statistical Department.

Table 2.2 draws on the official reports provided to the $C Y B$ by the Ministry of Finance. The CMCS represented the largest proportion of the Government's revenue for each year. It ranged from 42 per cent to 54 per cent of total revenue. Any large disruption in the functioning of the Service therefore would conceivably have a direct effect on the financial state of the government. The two other substantial sources of revenue for the government came from salt taxes and proceeds from borrowing. These sources combined contributed around 40 per cent of total revenue. The National government did not receive all of the proceeds from salt taxes, however, as a proportion was allocated to each province. The fact that net proceeds from borrowing represented between 16.8 per cent and 30.3 per 


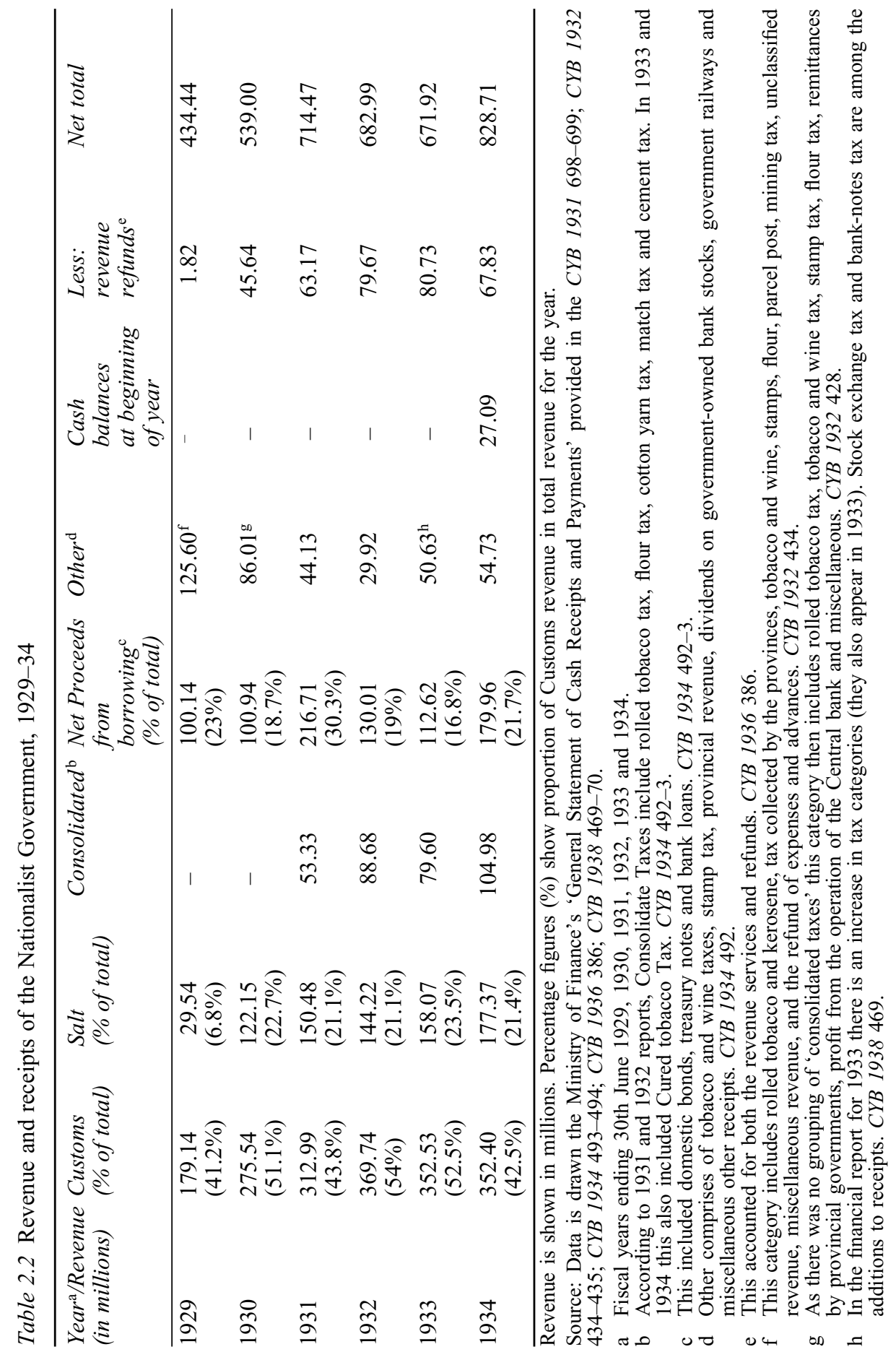


cent of total revenue emphasizes the scale of China's deficit problem. The year 1931 was the high point of government borrowing with revenue from loans doubling in value from 1930. Another source of revenue that was not listed in official reports was that of the cultivation and sale of opium. While this was illegal in theory, in practice it was officially condoned and provided a valuable income to the government and provincial leaders. ${ }^{45}$

In terms of government expenditure the two most significant demands on existing finances were clearly military expenses and loan servicing. For example, in the early 1930s military expenses represented in excess of 40 per cent of total government spending. ${ }^{46}$ Such high levels of expenditure serve to indicate how highly militarized the GMD remained, and alludes to the ongoing difficulties Jiang faced when attempting to curb the size of China's armed forces. Military expenditure placed significant strains on the government's finances. The $C Y B$ for 1934 discussed the problems such exorbitant spending on the military caused the government. ${ }^{47}$

Loan servicing was the other main demand of government revenues. This constituted from 24.4 per cent to 35 per cent of total expenditure. ${ }^{48}$ In each balance of payments not only did the government have a substantial, ongoing loan repayment commitment, it also continued to issue bonds and to take out loans, both internal and foreign. This reveals the serious deficit problem the government was struggling to control. Foreign loan consortiums were clearly in a powerful position by virtue of the Chinese Government's continuing cycle of indebtedness. The foreign powers, knowing that the bulk of revenue was absorbed by military and loan repayments with little left over for civilian expenses, were aware of the possibility that the government might be tempted to rashly spend loans for day-to-day budgetary purposes rather than long-term goals. ${ }^{49}$ Military expenditure and loans took anywhere from 70 per cent to 80 per cent of government revenue. Such large commitments left limited revenues available to the government. ${ }^{50}$

A great proportion of China's foreign loans were secured against the Customs. This suggests the close connection between Western interests in China and the role of the CMCS in the Republic. Foreign loans to China were deeply influenced by international politics and, while China's obligations were direct to the actual banks or syndicates advancing the money, these obligations were regarded by the interested foreign powers as a matter of vital concern in their general policy towards China. ${ }^{51}$ The securing of foreign loans against a foreign-dominated CMCS lends further credence the idea of the Service as centripetal to the practice of Western imperialism in the Republic. In 1931, the loans secured against the CMCS included the Chinese Imperial 4 per cent Gold Loan of 1895 (£15,820,000); Chinese Imperial 5 per cent Gold Loan of 1896 (£16,000,000); Chinese Imperial 4.5 per cent Gold Loan of 1898 ( $£ 16,000,000)$; 5 per cent Reorganisation Loan of 1913 ( $£ 25,000,000) ; 5$ per cent Gold Loan of 1925 (US\$43,893,900); 
and Chinese Republic 6 per cent Gold Loan of 1928 (US\$5,000,000). These loans were not the only secured loans made by foreign powers to the Chinese Government but the most substantial loans were all secured against the CMCS. Through this the Service was not merely a revenuegenerating institution for the Chinese Government but, rather, was integral in generating revenue for the foreign powers, albeit in an indirect manner. This revenue was realized in the form of a security for foreign loans and also an assurance of regular repayments of interest. Importantly, the prerogative for the payment or defaulting of loans was not left to the Chinese Government; instead the CMCS managed this as one of their responsibilities.

Internal loans were similarly secured against Customs revenue. The value of loans authorized and issued between 1928 and 1933 against the Customs totalled in excess of two billion dollars. ${ }^{52}$ The sheer size of these loans has two significant implications. First, the amount of these loans illustrates the heavy reliance the Chinese Government was placing on the Customs, not merely to generate revenue but to provide the security for the floating of large internal loans. Second, the Customs revenue was reliable enough to provide security for such amounts but it could never realistically be capable of repaying such debts. Presumably though, the releasing of bonds would have been directed at the foreign consortium and also towards wealthy Chinese investors.

Through the CMCS the Chinese Government was able to gain, most importantly, security for foreign and internal loans. The foreign basis of the Customs in turn provided an extra element of security for the foreign powers and therefore their investments. Through this Chinese dependency foreign investors could gain some ascendancy in China's economic affairs. Certainly, the indebtedness of China and the need to secure repayment implied the potential for foreign intervention in Chinese affairs. There was a definite dependency cycle established between the government and the foreign powers through the Nationalists' deficit. The Customs represented a significant revenue source for the government, even more so because it was an institution that offered stability as one of its central tenets.

After having examined the significance of the Customs to the national government's finances, it is essential to explore what constituted the revenue of the Service. Statistics featured in $C Y B$ and in the Customs Annual reports are the primary mode for assessing the economic performance of the Service. As illustrated in Table 2.3, figures for CMCS revenue for the 1923-37 period reveal constant growth. During this time there was an increase of almost 350 per cent. This growth, however, was not steady and, for example, in 1931 there is a dramatic peak in the total of Customs revenue due in part to the initiation of the collection of inter-port duties and famine and flood relief surtaxes in response to hardships in some regions and the inundation of the Yangzi. ${ }^{53}$ The 1931 total was, as a result, a dramatic 137 per cent increase from the total registered for 1930. This 
Table 2.3 Revenue of the Maritime Customs Service, 1923-37

\begin{tabular}{lllllllllr}
\hline Year & $\begin{array}{l}\text { Import } \\
\text { duty }\end{array}$ & $\begin{array}{l}\text { Export } \\
\text { duty }\end{array}$ & $\begin{array}{l}\text { Coast } \\
\text { trade } \\
\text { duty }\end{array}$ & $\begin{array}{l}\text { Inter- } \\
\text { port } \\
\text { duty }\end{array}$ & $\begin{array}{l}\text { Transit } \\
\text { dues }^{\mathrm{b}}\end{array}$ & $\begin{array}{l}\text { Ton- } \\
\text { nage } \\
\text { dues }\end{array}$ & $\begin{array}{l}\text { Revenue Famine } \\
\text { surtax }\end{array}$ & $\begin{array}{l}\text { Total } \\
\text { or flood } \\
\text { relief } \\
\text { surtax }^{\mathrm{c}}\end{array}$ \\
\hline 1923 & 50.64 & 35.32 & 4.13 & - & 5.00 & 3.74 & - & - & 98.94 \\
1924 & 59.37 & 36.05 & 3.97 & - & 4.85 & 4.19 & - & - & 108.43 \\
1925 & 56.66 & 38.28 & 4.12 & - & 5.73 & 4.07 & - & 1.33 & 110.19 \\
1926 & 66.77 & 40.92 & 4.35 & - & 5.16 & 4.52 & - & 3.60 & 125.32 \\
1927 & 54.38 & 39.67 & 3.87 & - & 4.88 & 4.28 & - & 0.07 & 107.16 \\
1928 & 72.47 & 42.16 & 4.21 & - & 4.85 & 4.62 & - & - & 128.27 \\
1929 & 167.10 & 56.54 & 5.66 & - & 3.85 & 4.95 & - & - & 238.11 \\
1930 & 211.64 & 55.38 & 6.30 & - & 3.25 & 4.84 & - & - & 281.41 \\
1931 & 314.69 & 47.83 & - & 15.65 & - & 5.24 & - & 1.60 & 385.00 \\
1932 & 236.29 & 26.78 & - & 20.55 & - & 4.27 & 5.07 & 19.02 & 311.98 \\
1933 & 265.61 & 23.24 & - & 18.00 & - & 4.40 & 14.13 & 14.14 & 339.52 \\
1934 & 260.22 & 24.70 & - & 16.97 & - & 4.30 & 14.22 & 14.24 & 334.65 \\
1935 & 250.17 & 20.73 & - & 13.21 & - & 4.32 & 13.53 & 13.56 & 315.52 \\
1936 & 254.54 & 24.47 & - & 13.68 & - & 4.03 & 13.94 & 13.97 & 324.63 \\
1937 & 261.29 & 29.07 & - & 20.15 & - & 3.22 & 14.58 & 14.59 & 342.90 \\
\hline
\end{tabular}

a On 1 January 1931 coast trade duty was abolished. CYB 1931699.

b On I January 1931 transit dues were abolished. CYB 1931699.

c This was a $10 \%$ customs surtax on all goods (except those exempted) to contribute to the cost of famine relief along the Yangzi. CYB 1934497.

Figures in millions of standard dollars St.\$.

The above table is presented in standard dollars, using the officially set exchange rate of Haikwan tael (Hk.Tl) $100=\$ 155.80$ to calculate the $1923-5$ figures and to randomly check other figures.

Source: Maritime Customs reports and CYB 1934.

would also have been a result of the Nationalists having gained tariff autonomy and having increased their tariffs accordingly. Import and export duty constituted the largest sources of revenue for the Customs. Of these, however, import duties always remained the dominant concern. These two duties confirm the significance of the Service in moderating and controlling trade to and from China.

As the revenue of the Service increased, the calls made on this source were twofold. They involved maintaining the Service and also contributing to Chinese Government interests. Wright's detailed work on the CMCS provides a thorough account of not only the claims on the revenue but also the disposal of the Customs surplus. He discusses the 'first charges on the revenue'; namely, all expenditure necessary to maintain the service in full, all costs incurred in the collection and banking of the revenue. This also encompassed 'special appropriations for the upkeep of the Service and allied interests or as grants to the Government for specified objects which have been approved by the Diplomatic body'. ${ }^{54}$ 
Clearly the foreign powers held considerable interest in China's finances and most particularly in the fate of the Service. This is understandable considering the CMCS' importance in relation to China's financial health. As can be seen in the preceding section, the Customs, over time, came to represent a significant force for the economic prosperity of China. It played a vital role in financing the Republic and provided a secure source for foreign loans. Foreign powers could rest easy in the knowledge that the Customs would secure their interests because a hard-working foreign Inspectorate was firmly at its helm.

\section{The London Office}

[The London Office] acted as a kind of stationery and supply office for the whole Service, also as an information bureau and an examination center. That much was known of it. But a large part of its work was highly confidential, and all who joined it were under a pledge of secrecy not to divulge, under the severest penalties, what was done. It was a hush-hush office..$^{55}$

From the 1870s the Service maintained a LO. This office served a diverse number of roles in supporting the CMCS, not just administratively but by being responsible for a lot of the behind the scenes promotion of the Service. The LO vetted the majority of recruits for the indoor staff who were then sent off to serve in China. This section examines the LO and the roles it played in supporting and perpetuating foreign interests in the CMCS. While touching on the LO in the early IMCS era, the following examination will focus on the 1920s and 1930s. This office remains an intriguing aspect of the CMCS, its existence alone providing further evidence of the British dominance of the Service. ${ }^{56}$

The legendary Hart was responsible for the establishing of the LO for the Customs with a Non-Resident Secretary (NRS) in 1873. The office was located in 26 Old Queen Street Westminster, at the heart of London's diplomatic and administrative precinct. The functions of this London 'outpost' of China's Customs Service are largely unexplored in academic works; likewise the relationship between the IG and the NRS remains shadowy. This obscurity may be due in part to the perception of the peripheral role played by this office in relation to the Customs establishments throughout China. Such perceptions are deceptive however, as the LO constituted a significant link for the CMCS and its British supporters, the import of which should not be underestimated. The establishing of the NRS in London emphasized the ascendancy of British interests in the Service and a continued imperialist agenda.

Hart's motivations for establishing a London branch of the Customs were influenced by the practicalities of having a London agent to handle Customs affairs. James Campbell, who had been in London for several years due to ill health, had proven himself to be an asset in Hart's eyes 
by handling such sensitive matters as the contentious von Grumpach case. ${ }^{57}$ Therefore in August 1873 Hart discussed the possibility of an arrangement with Campbell that would make the need for an agent unnecessary. $\mathrm{He}$ outlined to Campbell:

I must remember that, from the way you have acted during the last two years at home, it is evident you would, in other important ways, be useful to me as a man who knows China (as you do), and no one could be fully employed and usefully employed except a man thoroughly trusted by me (as you are) and personally loyal to me (as I fully believe you to be). ${ }^{58}$

Hart stressed the need for a man he could not only trust but that importantly had personal loyalty to the IG. This reflects to some extent the tensions that had been placed on the Customs by the British diplomatic body during its early years, these pressures culminating in several challenges to the authority of the Customs establishment in China. As IG Hart had the need for a London contact that would not only offer support to the Inspectorate but who also could be relied on to defend the best interests of the service.

The selection of Campbell's official title as NRS had implications on what direction the London establishment would take. While Hart had initially considered calling Campbell Supply Secretary or Chinese Commissioner, he discarded both as being understated and too grandiose respectively. He was aware of the need to select a title that would neither restrict Campbell's activities nor bring him under critical scrutiny from Diplomatic or Chinese circles. ${ }^{59}$ Campbell's role would be twofold: buying and forwarding supplies and attending to confidential work delegated by the IG. Through this simple outline of the duties of the NRS there were indications that the LO could, in time, further expand the scope of its activities according to the needs of the Inspectorate.

The LO was a small administrative establishment. It appears that only a typist-clerk, office keeper and office boy supported the NRS. While Hart was the originating force behind this office, his letters often betray reluctance to continuing to commit funds to the upkeep of such an establishment. ${ }^{60}$ The staffing numbers of the LO did not dramatically change during the course of its existence but in the 1920s a new recruit to the Service would often spend some time as an assistant to the NRS before being sent to China.

Ironically, even with the increasing significance of the CMCS revenue during the mid years of the Republic (when compared to the struggle Hart and the IMCS often had to meet indemnity and loan commitments), the LO faced threats to its continuation in the 1920s. During Aglen's leadership the existence of the LO came under intense scrutiny, both in Britain and China. An income tax ruling in 1924 (Aglen was unable to secure an 
exemption) meant that Customs staff in London were taxed according to British law. ${ }^{61} \mathrm{He}$ wrote:

The Foreign Office may be able to help us. They understood the situation, or at any rate it can be explained to them, and, seeing how much depends on the Customs and what a very considerable British interest it is, they might be able to bring some weight to bear in the direction of freeing us from embarrassment. But when all is said and done we cannot expect that Great Britain will alter her laws for our benefit. ${ }^{62}$

Aglen concluded that it might be possible to use a bluff that the LO would relocate to either Paris or Washington but that this would not eliminate the fact that the CMCS wanted to retain a recruiting office in London regardless of the outcome of the tax ruling. From the sentiments in Aglen's letter and the way the Service worked around the inconvenience of these taxes, it is apparent that the LO was considered indispensable to the Service.

This income tax ruling caused concern for LO employees, since their China based colleagues had no such taxes. This income tax was considered a disadvantage when working at the LO which, along with the higher cost of living, was exacerbated by the fact that staff were often not given choice in their appointment to this post. To counteract this, their wages were safeguarded against rises in the exchange and they were accorded a rent allowance. ${ }^{63}$ In response to the income tax ruling, there was an examination of the numbers of staff at the LO and also the composition of the staff. Aglen suggested the possibility of recruiting permanent staff from London and thus allowing the CMCS staff to return to China. NRS Bowra (appointed in 1924), however, sounded a note of alarm at this prospect, as he believed there must be at least a second in charge who was from the Service. He advised Aglen:

I am inclined to think that on the whole (and even if the service has to pay his income tax for him) it would be better to have as No 2 here a China-trained man who knows China and the Service. Otherwise the burden on the N.R.S. would be an unduly heavy one, as he would have to interview personally everyone who wants to know anything about China or Service conditions ... leaving him little time for anything else, in view of the constant string of callers here. ${ }^{64}$

Should the NRS fall ill or take leave, Bowra was convinced that an able and experienced Customs man would be needed to fill the void ${ }^{65}$ Despite these discussions, no further action along these lines was taken. The employment of local staff in the LO came under scrutiny again during Maze's leadership. A review of the LO, submitted by M.O. Law to Maze (c.1930), outlined in detail the cost of running the office. ${ }^{66}$ It also suggested possible measures to reduce not only expenses but also, the number of 
China staff being retained in London when locally employed staff could as easily fill their jobs. After approximating the annual cost of running the $\mathrm{LO}$ at around $£ 5,444$, Law proposed downsizing that he predicted would reduce the annual running costs by half. He suggested that the NRS lived on the premises to cut down rental allowances. ${ }^{67}$ Whether or not this was acted upon is unclear; however, it is significant that the IG solicited such reports.

During the Hart and Campbell era, the LO fulfilled roles more suited to a Chinese legation. Moreover, the LO of the IMCS era could be seen as both presenting and representing China in Europe. In 1873 it organized a Chinese display at an exhibition in Vienna, and until 1905 continued to make successful representations in exhibitions in the West. The IMCS presented the arts, produce and industries of China at these exhibitions. Wright comments that they helped 'the world to understand and appreciate better the life and culture of the Chinese people' ${ }^{68}$ Campbell often coordinated such displays, and in this manner the IMCS was part of the colonial desire to represent Asia to Europe.

The NRS was no mere secretary of supplies. Indicative of the post is the fact that Campbell played an integral role in negotiations over the 'Feihoo affair', involving the French Navy's arrest of the IMCS cruiser in October 1884, and also disputes in relation to Tonkin (1885). ${ }^{69}$ Such farreaching influence, however, was not enjoyed by the LO in the Republican period as China's legation in London was well established and, in a reflection of the Nationalists' rise in China (looked on with a certain amount of regret and trepidation by some CMCS staff and old China hands), the legation could well manage its own affairs. Gone were the days when the Chinese legation in Britain had taken its lead from the LO..$^{70}$

In the 1920s and 1930s the LO linked the Service with affairs in Britain. Moreover it provided an opportunity to raise the profile of the CMCS in the eyes of British business and political leaders. A discussion between Aglen and Bowra with regard to the role of the LO is telling, as Aglen specified that the office should not assume any representative functions, nor should it compete socially or officially with the Chinese legation. ${ }^{71}$ This discussion confirms that the LO had in the past offered a challenge to the Chinese legation and alluded that potential competition did in fact remain through its network of contacts. Bowra for his part, was conscious of underlying tensions between the $\mathrm{LO}$ and the Chinese legation. In his memoirs he described the Chinese legation in London as 'eyeing us [the LO] with jealousy' and that he had realized 'any attempt at self-assertion on our part would have made difficulties for the IG in Peking'..$^{72}$ Clearly, throughout the Republic there was a consciousness that the LO needed discretion in its dealings.

Despite the focus on support the LO was simultaneously cultivating a network of allies. These contacts reached into the echelons of the British Foreign Office, banking circles and Parliament. Aglen instructed Bowra: 
There are one or two people that we must keep in touch with but they are extremely few and, so far as I know, the only ones who are specially important are: the Bank, Sir John Jordan, the Far Eastern Department of the Foreign Office, Admiral Learmouth, Trinity House, and perhaps it would be a good thing to get to know the people in the Overseas Department of the Board of Trade. Then there are, of course, Ambassadors whom one has previously known in Peking; they are always disposed to be friendly and it does no harm to call on them if they are appointed to London. But I don't want any pushing of the London office in a social way; I much prefer people to come to us and for our having a ready means of access to such people as it may be necessary for me to keep in contact with. ${ }^{73}$

Aglen obviously expected certain channels of communications to be maintained especially with influential and, even more importantly, sympathetic personages. This desire to keep Chinese affairs in prominence in Britain is echoed throughout the $Z$ Letters, with Aglen encouraging Bowra to hint to politicians to keep China in the public gaze. ${ }^{74}$

The maintenance of a sympathetic network continued throughout the 1930s under the watchful guidance of Maze. On several occasions NRS Macoun reported to Maze the courtesy calls he had been making as part of his duties. Groups or individuals frequently mentioned included the Foreign Office, the Department of Overseas Trade, Sir John Pratt, the China Association and Sir C. Addis (a prominent banker). Of his duties, Macoun wrote: 'I realise how useful it is to be in close touch with official, banking and commercial people in London who exercise influence in matters connected with China. ${ }^{75}$ Evidently the maintenance of influential contacts was integral to the role of the NRS. Owing to tensions between Maze and the British Minister in China, Sir Miles Wedderburn Lampson, Maze often directed informal correspondence to the Foreign Office through the NRS. Most obviously during Maze's leadership, the LO was a useful avenue for gauging establishment reaction to different issues through informal channels. This was particularly the case during the proposed Hong Kong-China Trade and Customs Agreement, which dominated attention in 1930 (this is discussed in detail in Chapter 5). ${ }^{76}$ The office provided the IG with intelligence on the general British stance before any official discussions were entered into. As the CMCS was drawn deeper into Chinese political affairs during the Nationalist era, the LO increased its profile in the influential circles of finance and government back home.

The LO played an integral role in recruiting employees for the indoor staff of the Service. In doing so, this office had a significant part in shaping the CMCS by virtue of the type of men it sought to recruit. Certain qualities were deemed desirable in the recruiting process, and in the development of entrance requirements, including examinations and procedures, the NRS and the indoor staff were encouraging an esprit de corps for the service. 
Through this sense of an 'ideal type' an image of the 'Customs man' begins to emerge.

The Inspectorate continually represented personal integrity and principles as being synonymous with life in the Service. The Inspectorate often sought to advance the ideal of the trustworthy and diligent Customs man. ${ }^{77}$ In a semi-official circular of January 1923, Aglen stressed the need for not only the outdoor staff, but all staff, to keep a high moral standard as 'the fundamental reason for the employment of foreigners in the Maritime Customs Service is their personal integrity and that on this personal integrity alone the continued employment of foreigners depends' ${ }^{78}$ The emphasis on integrity and resisting a degeneration of standards can be found throughout many of his admonitions of staff. Supporting this was the fact that annual confidential reports on all staff took into account personal qualities of the employee, including manners, trustworthiness and discretion. ${ }^{79}$

Nominations for admission to the recruitment examinations could only be made directly to the IG. Consequently the IG was often approached by acquaintances (many of whom were in China) for consideration of a young relative at home. ${ }^{80}$ Nationals from all countries having treaties with China were eligible to apply. ${ }^{81}$ Recruitment to the indoor staff demanded not only scholarly ability but also recommendation from a rather exclusive group, including retired Customs' staff, old China hands, and the family and friends of current indoor staff. Applications were to be made in writing to the IG, including educational standards, testimonials, a photograph and health details. ${ }^{82}$ Although the suggestion of newspaper advertisements for the recruiting of staff was discussed between Aglen and the NRS, it was never implemented, furthering the image of a rather exclusive Customs network for appointing young men. The preferred age for candidates was between 19 and 23, although this could be extended at the IG's discretion.

The CMCS sought to attract potential civil service candidates to its ranks. In 1921 NRS Acheson wrote to Aglen that he believed the salary question was also important as 'men who are willing to join us at $£ 250$, the present value of a junior's pay, are not as a rule the men we want'. He concluded that to get the right type of man it was 'necessary now as it always has been to go one better than the British Civil Service'. ${ }^{83}$ There is little evidence to substantiate whether the CMCS really was successful in competing with the British Civil Service; although it is unlikely that a career in China was regarded as being as prestigious as the careers of those engaged directly in building the empire in India or other colonies.

In a further development of entry requirements in 1921, NRS Acheson wrote to Aglen with a proposed outline for the literary examination of candidates. It included English skills, essay writing, arithmetic and general knowledge along with an option of colloquial French or university standard entrance papers. ${ }^{84}$ The examination served primarily as a measure of general education skills and aptitude. A pamphlet for candidates published in 1922 introduced the CMCS and also included Forms A.-170 and 
A.-171, which directly pertain to admission to the Service. ${ }^{85}$ This guideline deals with the process of recruitment to the indoor staff. The NRS bore the main responsibility for setting the exam papers, the organizing of examination times, and the subsequent selection of the most successful candidates. The standard required for recruits was that of a good secondary education, and for the British applicants (who were the largest in number - in keeping with British dominance in the indoor staff) this meant that for 'British Candidates, in the absence of a university degree, Oxford and Cambridge Higher Certificates, etc., a place in the highest form in a public school of the first rank would be sufficient'. ${ }^{86}$ Educational tests alone did not always suffice in revealing those best suited to work in China. Certainly though, the CMCS attracted its share of recruits who later became scholars, writers and commentators on the China situation (this is perhaps a reflection on the often scholarly predilection of indoor staff recruits). ${ }^{87}$

The presentation and character of candidates came under scrutiny. In the vetting of candidates a mandatory luncheon became almost something of folklore and a rite of passage among CMCS staff. In a practice first implemented by Campbell, there would be time allowed during a scheduled examination period for him to have lunch with each prospective recruit. ${ }^{88}$ These lunches were designed to allow the NRS a better insight into the personality of the candidate but, of course, at the same time their table manners, attitude and general demeanour was assessed. ${ }^{89}$ Lunches were invariably held at the Thatched House Club, which was closely connected to the Conservative Club. ${ }^{90}$ By the 1920s the Thatched House Club had become a meeting point for retired CMCS staff and other ex-China men.

Recruits to the indoor staff had similar backgrounds to those of the officials of the diplomatic services in China. ${ }^{91}$ As previously discussed, the Service attempted to lure prospective civil service recruits to its ranks by offering better pay. Hart, himself being a prime example, had left a post in the diplomatic corps to take up his position in the new IMCS. Within the treaty ports the indoor staff of the CMCS mixed socially with the diplomatic corps and leading merchant class. There are also parallels between CMCS indoor staff and employees of the Hong Kong and Shanghai Banking Corporation. Similarities are found in recruitment criteria and also the encouraging of a sense of social identity through a sporting ethos. ${ }^{92}$ The CMCS paid attention to candidates' sporting abilities and hobbies; they were eager to employ good all-rounders. The similarities are evident in the Bank's desire to implement a language programme based on the model of the CMCS language programme. Because of a lack of incentives, however, they did not have as much success as the CMCS. ${ }^{93}$

The rates of pay for the indoor staff of the service were quite generous, especially as accommodation was provided at each port. ${ }^{94}$ With satisfactory conduct, study of Chinese and adaptation to Service life, 4th Assistant Bs were recommended to 4th Assistant A position within six months of their arrival in China. This was accompanied by a pay increase. Admission 
forms for the indoor staff specified that candidates must be unmarried. ${ }^{95}$ Not only was the 'marriage of junior employees' not approved but in extreme cases of marriage after only a few months in the Service, the employee was likely to be dismissed. Men who married while still in a junior position had no claims to Customs housing and generally had to then find their own living quarters. ${ }^{96}$ This restriction on marriage was very similar to the stipulations of Hong Kong and Shanghai Banking Corporation, although it had a ten-year constraint on its junior staff. ${ }^{97}$ As recruits were unmarried and, in most cases, enjoying their first taste of long-distance travel, there was concern that they might be corrupted by their first China experiences. Acheson wrote:

The objection I feel to recruiting lads of 19 is that if they are transplanted to a China port at that age, they inevitably adopt China port standards of life and no other: if they were invariably posted to Peking and looked after when there, it would be another matter. ${ }^{98}$

Shanghai - the 'Paris of the East', a dynamic and vibrant city - offered dance clubs, bars and more temptations to the new arrival in China. ${ }^{99}$ For instance gambling was a 'popular illegal pastime' and with easy access to credit systems many newcomers to the treaty ports lived beyond their means. ${ }^{100}$ With the knowledge of such distractions, the admission form for candidates indicated that all new recruits would have their behaviour observed during the first years of their Service. ${ }^{101}$ Furthermore, the IG reserved the right to discharge any staff who had proved to be unsatisfactory.

The physical health of candidates was an important consideration. Each candidate had to undergo a medical examination before they could be accepted into the Service. This procedure is understandable, as the often unsanitary conditions in various ports and Customs outposts often took its toll on the newer and, therefore, less resistant employees. In his memoirs, Rasmussen described his first posting to Zhenjiang and recalled that, while the small concession had a doctor who was a good surgeon, it was a hospital and skilled nursing that was most needed. He cited the prevalence of diseases such as cholera, typhoid and smallpox, and that in the event of someone falling seriously ill, all the men would share the nursing responsibilities. ${ }^{102}$ Poor health was a hazard and often curtailed careers. ${ }^{103}$ Consequently, candidates who were in poor physical condition in London were never given an appointment to China.

The inevitable stresses caused by being thrust into a foreign culture also exacted a toll on some recruits. When discussing illness among the employees, it was the junior staff who were mentioned with most frequency. In one such letter Aglen writes:

Arrangements are being made to send home young Warry who has broken down in much the same way as P.L.O. Hill, and he will have 
to be invalided. By the way Hill's case is at a loose end and it will now have to be taken up. Acheson was in favour of allowing him to return to duty, but I consider that the risk is too great. I think I must make it a rule that when once an employee has become incapacitated owing to mental breakdown he must sever his connection with the Service.... Young Robillard is making a great fight for his life and is holding his own although his condition is extremely critical. ${ }^{104}$

Mental breakdown often claimed a share of employees. From such letters it is indisputable that China service held a certain amount of personal risk. It was important, therefore, for the NRS to try to ensure that candidates were both physically and mentally strong before sending them to China.

The role of the NRS in vetting and examining new recruits for the indoor staff drew to a close in the Nanjing decade. With the GMD's rise to power the position of foreigners in the Service was brought under intense scrutiny. In 1927, following the dismissal of Aglen, the recruitment of foreigners was suspended. ${ }^{105}$ In the Customs circular of January 1929, the principle for equality for Chinese and foreign staff was put forward. In addition a cessation of the recruitment of foreign staff was called. ${ }^{106}$ Chinese staff would fill any vacancies; the only exceptions to this would be when a technical expert was needed. Consequently, by 1927 the LO had ceased its role as a recruiting office for staff; instead it devoted more energy to supporting the Inspectorate and developing its network of contacts.

The LO was a vital complement to the foreign inspectorate. This Office supported the IG and provided him with an unofficial network of contact with influential figures known to be sympathetic to not only the CMCS but also Britain's interests in this Service. The position of NRS was a highly esteemed posting, a prized position for senior staff wishing to spend their final years before retirement in London. It was also a position requiring a skilled and energetic diplomat. From its inception and right through the Republic, the LO was never merely a supply office for the CMCS; it was a key element in ensuring and maintaining British interests in the Service. It did this not only through its recruitment processes but also through the maintenance of a network of allies.

\section{'A family along the China coast': life in the CMCS}

The overall impression of the Service from CMCS reports is one of a large and routine bureaucracy, dealing with cargoes and tariffs, traders and shipping. This is only a partial view. If the Service was all about tariffs and trade, it was equally about dealing with merchants, uncovering smugglers, making sure your Chinese boy did not take advantage of you, and doing the rounds of dinner parties. Commissioners and their senior staff mixed freely with consular staff of all nations and also with the representatives and power brokers of the large foreign merchant and banking firms. Life 
in the CMCS opened a window to the wonders of China and also to the often-hectic social scene of the treaty ports.

Yvonne King, née Le Bas (1913-), was born in Longzhou, where her father was stationed. ${ }^{107}$ Yvonne and her siblings grew up in the CMCS. Taking her involvement with the Service beyond her childhood years, Yvonne married a Customs man, Harold King, in 1931. So the first 37 years of her life were largely spent in China and intimately connected to the Customs. Her recollections teamed with other reminiscences of Customs men (predominantly the indoor staff) and consular staff provide a glimpse, albeit dimmed with the passing of time, of the privileged lives led by those in the upper echelons of the Service. King described her life in the CMCS:

Being in the Customs was a bit like having a large family scattered around, up and down the China coast, as well as in many inland cities. There was always news of various members and of their doings, transfers, promotions and so on. ${ }^{108}$

While there was a sense of camaraderie and of extended family among CMCS staff, family lives were fragmentary. Life in the Service did not lend itself to a settled existence. Duty at each Customs house was transitory and it was therefore difficult to establish lasting friendships. Wives and children would often return to the United Kingdom, Europe or America for long periods of time while husbands remained at their Customs posts. The Service provided allowances for men with families but most often children were raised and educated away from China.

Since indoor staff rotated from port to port with reasonable frequency, families also encountered disruption. When recalling their early life in China it is not surprising that some recalled a childhood lacking in a sense of permanency and the security of a family house. ${ }^{109}$ To further illustrate the frequency of these moves, an overview of Yvonne King's China experiences is useful. With her parents and then her own family she moved every three years (sometimes sooner) from 1913 right through to 1950. This included China postings, as well as leave time in Europe. ${ }^{110}$ Perry Anderson's reflection on his father, James Carew O'Goram Anderson's Customs career (1914-42) also shows a similar pattern of constant travel throughout China. ${ }^{111}$ James Anderson's ports of duty included Mukden, Beijing, Chongqing, Shanghai (on more than one occasion), Beihai, Mengzi outposts in Manchuria, Hong Kong, Hainan, Shantou and Longzhou. Home leave was also interspersed among these postings. While there was a sense of uncertainty with such constant movement, Briggs (a member of the Marine Department and Captain of various cruisers) recalls it as a worry-free existence as on arrival at a port a house would be ready and domestic staff available; ${ }^{112}$ these houses were often furnished, making the relocation somewhat easier. 
Customs employees were generally not married when they were sent out for their China service. Life in China could become tumultuous or even dangerous and wives faced such conditions alongside their husbands, as the Customs regulations reminded all. Health risks were exacerbated for women in terms of childbirth and raising a young family, as medical facilities were not always available. ${ }^{113}$ However, whenever possible, medical services were covered for Customs staff. ${ }^{114}$ Once married, they could rely on suitable accommodation being provided for their wives and families as they were transferred from port to port. Generally there were Chinese servants who 'went with the house'. ${ }^{115}$ Servants consisted of a boy, ${ }^{116}$ cook, coolie, wash-amah and gardener. ${ }^{117}$ For couples with a young family, it was relatively simple to find amahs (or Chinese nannies) to help in caring for the children. For example, Mrs Le Bas hired two amahs to help care for her five children. One of these was originally employed as a wash-amah, but became a valued addition to the family and stayed with the Le Bas family for around 60 years, caring for the next generation of children. ${ }^{118}$

Family life in the CMCS could be difficult as the scarcity of educational opportunities for children was a concern. Governesses were often employed to give the children a good foundation for their future schooling. The appointment of governesses was, however, not always as straightforward as families would have liked. Yvonne King writes about her first governess:

Mademoiselle Morange, it appears, was a most attractive young lady and Mother and Father had a difficult time coping with the many male admirers who flocked to the house hoping for an introduction or left notes asking her to contact them. Hence, one of the last things Father said to Mother before we left was 'for goodness sake, the next governess you bring out, make sure that she is a really ugly one!'. ${ }^{119}$

And sure enough, the family's next governess was very plain! ${ }^{120}$ Upon reaching secondary school age, children were generally sent to be educated either in Britain or Europe. ${ }^{121}$ Unlike many of the other Customs families, the Le Bas family did not send all their children home to the continent for an education. In 1920, when the three eldest children were roughly nine, ten and eleven years old, the family returned to France to arrange for their schooling. Yvonne and her sister Jacqueline had some schooling in France but were considered too young to be left there when their parents returned to China. As a result they remained with their parents and were educated at the various foreign schools around the ports.

For the single men in the Customs, families in the Service often provided the comforting reminders of home. Yvonne King recalled that in Beijing (1926-8) there seemed to be no shortage of young men dropping in to enjoy the homely atmosphere of her parent's house. She writes: 
there was always something happening and the gramophone was kept busy! Besides, our dear Mother, I have to add, was the original, authentic motherly type and so she 'adopted' quite a few of them, having an idea that they were rather homesick, many having only recently arrived from England, France or wherever! ${ }^{122}$

Families like the Le Bases clearly offered a refuge from loneliness and homesickness for the single employees of the Service. It is probable that the presence of such families also served to moderate some of the less desirable behaviour of the young recruits. As Anderson reflected, a concern was that young men often 'found solace' with local tea girls or concubines. ${ }^{123}$ It is not surprising that such entanglements occurred as China presented a strange environment with no 'visible morals' for young recruits. ${ }^{124}$ Shanghai: A Novel has as its main character a new recruit to the IMCS and traces his challenges in adapting to life and the temptations offered in the treaty ports. These temptations included the lure of opium and Chinese 'sing song' girls. ${ }^{125}$ Moreover, even for married men, long separations from the families often meant it was tempting to revert to their bachelor ways. ${ }^{126}$ No doubt then, Customs families provided some restraint on the behaviour of the single men.

Summer holidays were spent either house boating, touring, or at Customs holidays bungalows. ${ }^{127}$ These bungalows were located at the resort area of Beidaihe, ideally located some 80 miles from Beijing. Yvonne King recalled:

Our two summers were spent by the sea at Peitaiho. The Customs had three bungalows there and as ours was the largest family, we got the big one with a tennis court. It was great fun for us and all the various friends who came to stay for their holidays. ${ }^{128}$

Holiday surroundings such as these must have provided a pleasant change from the hot Beijing summer. Tennis, horse riding, paper chase and hunting parties were other activities staff enjoyed in their leisure time. ${ }^{129}$ When allowed a year's long-term leave, after every five years of service, staff would voyage home.

Customs Commissioners were provided with spacious and comfortable accommodation. This was not only conducive for family life but permitted the Commissioner to entertain and to host visiting dignitaries. Foreign staff could generally have accommodation ready for them in a port, by renting houses or apartments when their counterparts were on leave. ${ }^{130}$ Briggs described the senior CMCS staff as living in 'a suitable style and a certain amount of luxury, though extravagance was unheard of' ${ }^{131}$ Luxury is equated with comfort and servants. Yvonne King described the Commissioner's house at Zhifu as 'large and rambling with a messy garden and a tennis court'. ${ }^{132}$ This house also had an annexe with two bedrooms, a study and bathroom. Anderson's first wife, the novelist Stella Benson, described their house at Beihai as 'almost palatial', set in a large compound filled 
with flowering trees and shrubs. ${ }^{133}$ The Customs Commissioner's house in Macao gives a good indication of the conditions enjoyed by the more senior staff. This house was newly built when the Le Bas family moved into it in 1926. It had spacious grounds, generous verandahs and a tennis court; it also boasted a billiard room. ${ }^{134}$ This residence not only made an impressive mark on the streetscape, it also commanded exceptional views across Macao's harbour. (See Figures 2.2 to 2.4.)

Indoor staff enjoyed good social standing throughout the treaty ports and often Commissioners were in close contact with the legations. The diaries of British Minister to China Sir Miles Lampson often gave reference to social engagements with Customs staff, illustrative of their standing in treaty port society. ${ }^{135}$ Williams reflected on his contact with Lampson:

I have memories of many delightful receptions given by him in the magnificent Chinese open pavilion opposite to his official residence. Here I mixed with a thoroughly cosmopolitan throng of diplomats and military officers in uniforms glittering with decorations, and ladies and children attired in brilliant colours. ${ }^{136}$

One would suspect that only the more senior indoor staff would be invited to such functions. In his role as Deputy and then Acting Commissioner at Tianjin, Williams writes of often calling on gunboats when they visited port and of the hospitality he was always shown. ${ }^{137}$ In return he would invite the naval officers to tennis parties or to go out for picnics or shooting trips. Anderson described his parents' time at Kunming as 'a

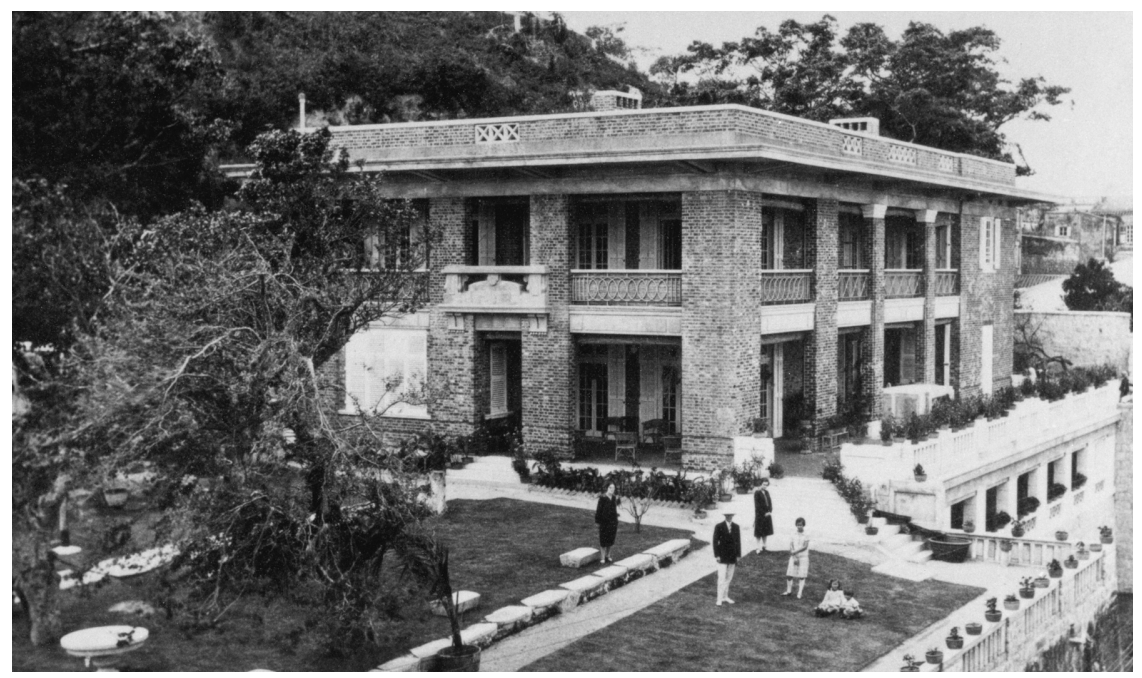

Figure 2.2 Customs Commissioner's house, Macao c.1926 with Le Bas family in the foreground (reproduced by courtesy of Mrs Yvonne King) 


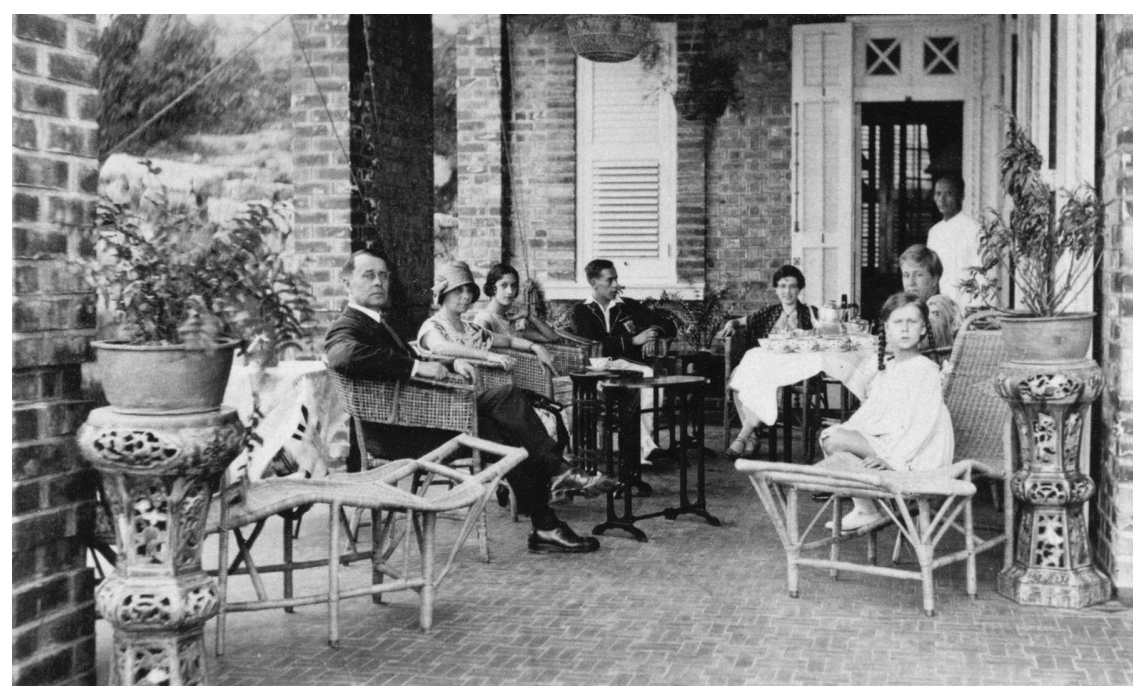

Figure 2.3 Customs Commissioner's house, Macao c.1926; Commissioner Le Bas (left) entertaining guests. (Yvonne King née Le Bas is the child seated at the right) (reproduced by courtesy of Mrs Yvonne King)

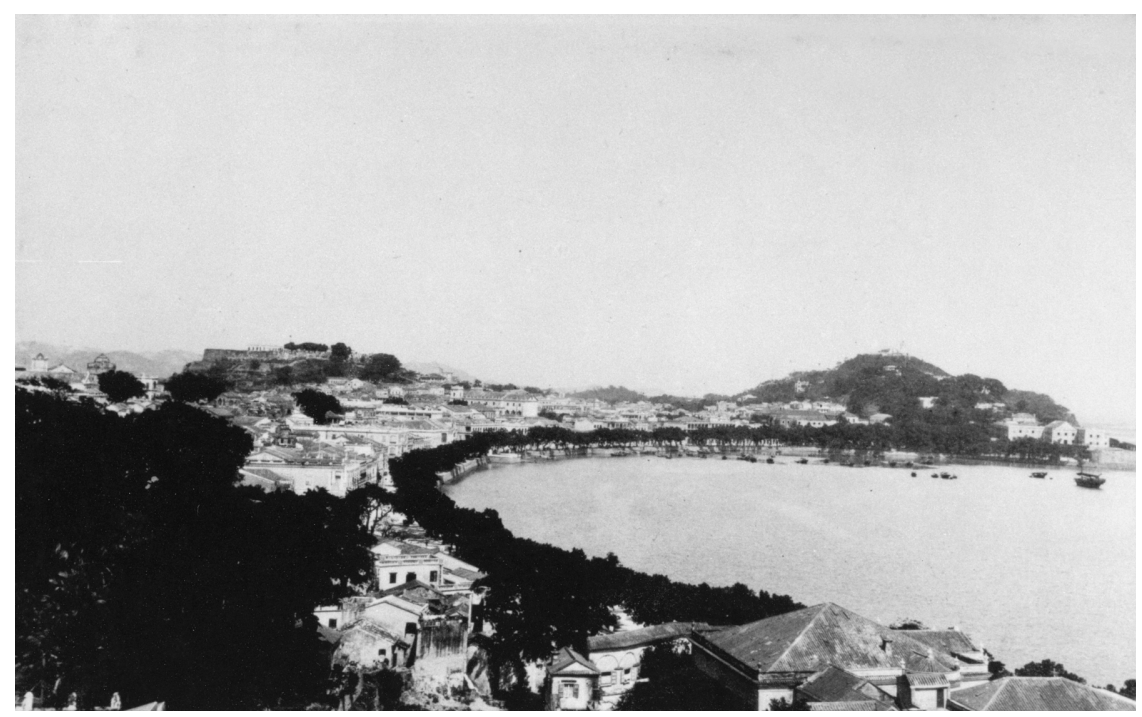

Figure 2.4 View over Macao from the Customs Commissioner's house (reproduced by courtesy of Mrs Yvonne King) 
golden age in family legend' filled with fêtes, children's parties and social engagements. ${ }^{138}$ Thus the Customs Commissioners in particular took a lead role in social gatherings for the foreign community in their respective port or outpost. Briggs, as a member of the Marine Department, represents another facet of the Service, and he described the position of CMCS staff in Hong Kong as not fitting with any social group but having 'ready made friends' within the Service. ${ }^{139} \mathrm{He}$ mentions that they were eligible for the various clubs (such as the Royal Hong Kong Golf Club) and that he often socialized with Service people as well as other friends. There is a sense here that the transient lifestyle of CMCS staff made it sometimes difficult to form friendships outside the Service.

While Customs Commissioners could mix freely with consular staff and merchants, there was, however, an unspoken hierarchy in the order of precedence each group should expect. Yvonne King recounted a story of when she and her husband were stationed in Xiamen. A visiting Admiral invited them to a dinner on his British battle ship. She explained:

We were asked to go on board to dinner together with people like the Hongkong bank and from Butterfield and Swire and all those people. Now the British consul in Amoy at the time didn't have a wife or at least his wife was in England or something ... I was only twentynine or thirty at the time and I was rather overcome because I had to sit at the right of the Admiral and all the other older women were sitting at the lower part of the table. This struck me very much you know, the fact that the Customs were always before any merchants but after the consular people. ${ }^{140}$

A sense of status and decorum was important in treaty port community and also within the Service itself. Briggs recalled a social highlight in Shanghai being a dinner hosted by IG Maze and his wife. ${ }^{141}$ This was a formal affair and care was taken that people of compatible rank were invited. Socially, wives played an important role, acting as hostesses and putting forward a good face when entertaining. The ability to play either bridge or mahjong was considered essential as social invitations often centered on these activities. ${ }^{142}$

The pressure of social norms and underlying racism also affected the social lives of CMCS staff. While there was a division between foreign or local, and outdoor or indoor, there was also a consciousness of who one mixed with. A number of Customs men married Russian women and also Eurasians. ${ }^{143}$ But it was the Eurasian community that received greatest disapproval, this no doubt being largely due to their challenging of social norms by the blurring of racial boundaries. Briggs described them as not accepted by either the Chinese or foreign communities. He recounted that when in Shanghai he accompanied the Secretary of the Coast Inspectorate, Gander, and his Eurasian wife to the cinema. Lady Maze and other CMCS 
parties were also present. On enquiring as to Brigg's identity, Lady Maze reportedly offered the following advice: 'tell him that his wife may not be accepted here, when she comes out, unless he changes his friends. ${ }^{144}$ Briggs recalled he had a number of Eurasian friends but few in Shanghai. ${ }^{145}$ Although the CMCS community was considered warm and welcoming, it too was governed by larger preconceptions of socially acceptable relations.

Customs cruisers were often employed not only in preventive work but also for social purposes. Commissioner Bell would often take his family out in one of the Customs armed merchant cruisers for a picnic at one of Hong Kong's bays. ${ }^{146}$ Customs launches were also employed for hosting larger groups of the foreign and local community. Guests could be invited by the Commissioner to enjoy a day on the water, considered a rare treat. ${ }^{147}$ Obviously, this would also have served as a good public relations exercise for the Customs Commissioner. Expenses for such outings were covered by an entertainment allowance from the Inspectorate. Williams also fondly recalled leisure outings. When stationed at the outport of Jiangmen in South China, he enjoyed many picnic parties on the Customs launch while making visits of inspection along the river. ${ }^{148} \mathrm{He}$ mentioned later buying a sailing-houseboat, which his family used for picnics and shooting trips. ${ }^{149}$ Similarly, inspection trips to lighthouses often meant a day of adventuring and picnicking for the children of the Commissioner. ${ }^{150}$ So for the indoor staff and their families, life at the ports was rarely isolated or dull. Even at the smaller posts the foreign community was commonly close knit and in this way there was always a steady stream of social engagements and activities to partake of. (See Figures 2.5 and 2.6.)

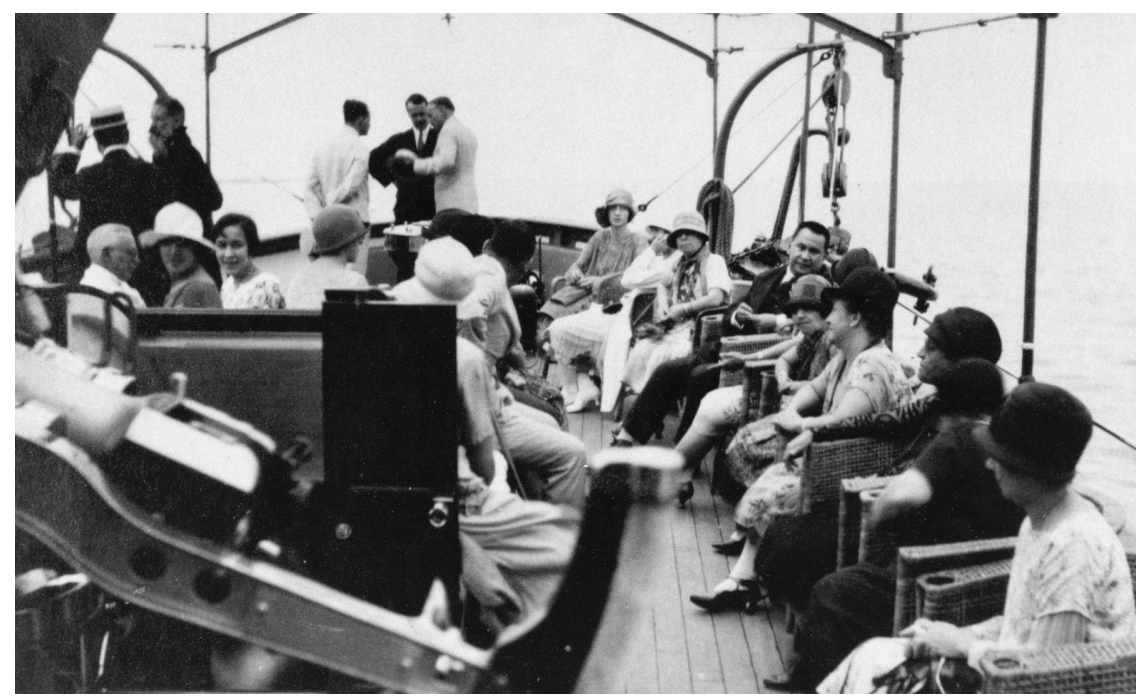

Figure 2.5 Social function aboard a Customs Cruiser, hosted by Commissioner Le Bas c.1926 (reproduced by courtesy of Mrs Yvonne King) 


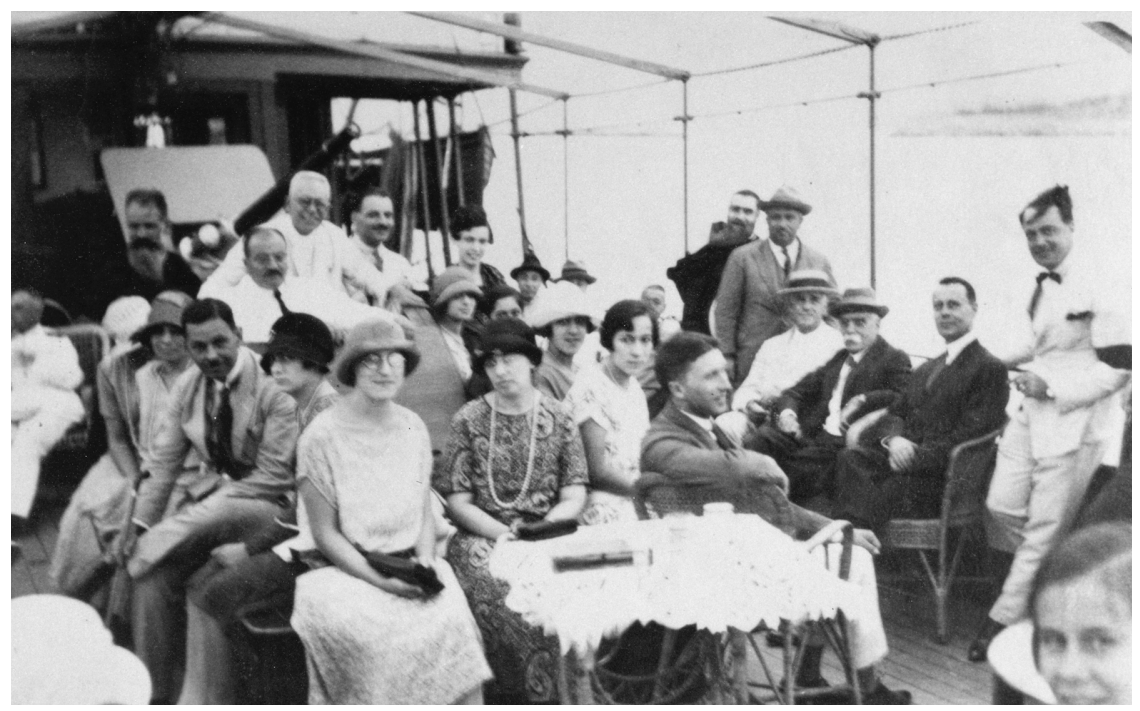

Figure 2.6 Social function aboard a Customs Cruiser, hosted by Commissioner Le Bas c.1926 (reproduced by courtesy of Mrs Yvonne King)

This brief interlude provides a glimpse of a lifestyle long since vanished along with treaty port China. Those fortunate to be enlisted into the indoor staff of the Customs service enjoyed privileged lives in the ports. Despite the often-harsh realities of an underdeveloped environment, Customs employees led a comfortable life, residing in well-equipped, spacious homes attended by servants. They moved in the elite social circles of the treaty ports. In many ways then, Customs staff were sheltered from life in China; this lifestyle underwent inevitable change as war engulfed China in the mid-1930s. 


\section{Gunboats and revenue, 1923-7}

This chapter charts the CMCS as it encountered the rise of the nationalist GMD and anti-imperialist sentiment. For the CMCS the 1920s represented a rapidly shifting political kaleidoscope within which the Service had to chart its direction. The maintenance of the Service's integrity was paramount during this unstable period. From 1923 to 1927 there were three prominent challenges to the CMCS, namely the Guangzhou (Canton) Customs controversy, the Guangzhou-Hong Kong boycott and the dismissal of Aglen as Inspector General (IG). These events and the issues surrounding them signify a dramatic shift in the fortunes of the Service. While in 1923 the CMCS was protected by gunboat diplomacy, by 1926 the Service was noticeably alone in defending its integrity. This was further emphasized with the dismissal of Aglen by the northern militarists. This evolution in the status of the Service, in foreign and Chinese eyes, signified an uncertain future for the CMCS in the Republic.

This chapter is, in many ways, an attempt to rewrite the CMCS back into the events of 1923-7. This is especially important as, while texts and documents relating to the Service are available, the actual role of the CMCS is marginalized. When exploring the events that embroil the CMCS, the fate of the Service is brought to the fore. Throughout the events in Guangzhou and Hong Kong, the CMCS was consistently in the background despite its having direct involvement in what was happening. The end result of this being the mistaken assumption that those events went on around the Customs without there being much reaction from the Service. This chapter redirects attention to the Service to allow a better understanding of the CMCS and its experiences as it encountered the rise of the Nationalists.

\section{Sun Yatsen and the Guangzhou Customs, 1923}

Sun Yatsen's claims for a pro rata share of the Guangzhou Customs revenue in 1923 triggered a rallying of foreign naval forces in Guangzhou's harbour to dissuade him from action. Gunboat diplomacy, in the form of a multinational naval demonstration, was employed to protect not only the integrity 
of the Customs but, more importantly, foreign interests in the Service. The Guangzhou Government's claims against the Customs were indicative of a chaotic struggle for political survival. Tensions surrounding the Guangzhou Customs lasted from September 1923 to early 1924. In response to stalling tactics by the diplomatic body, ${ }^{1}$ Sun's claims (which had at first been restricted to a pro rata share of revenue) became more aggressive, threatening to oust the Customs administration if they did not comply with his wishes. Prompted into action by such threats, the diplomatic body showed a united front against Sun's challenge to their interests. While the powers were successful in thwarting Sun's claims, their actions fuelled anti-foreign sentiment. This in turn encouraged the further expressions of Chinese resentment against the CMCS and all that it represented.

In the months prior to his claims against the CMCS, Sun had resumed leadership of the Guangzhou Government, which was beleaguered both by local rivalry in the form of Chen Jiongming's forces and also by militarist factions to the north. In 1922 Sun fled Guangzhou, ousted by the military forces of his government loyal to Chen. ${ }^{2}$ During this interlude in Shanghai, Sun began to foster connections with the Soviets and was visited by Adolf Joffe to discuss the possibility of developing a special relationship between the GMD and the Chinese Communist Party (CCP). ${ }^{3}$ After returning from Shanghai to Guangzhou in early 1923, Sun re-established his leadership as Generalissimo of the Nationalists and sought to extend their tenuous hold in the south-west. ${ }^{4}$ This was the third Guangzhou Government that Sun headed, and as leader he was faced with a movement with poor internal organization and, arguably, no devised strategy for achieving any reformation of China's political arena. ${ }^{5}$ Apart from local challenges to Sun's government, namely Chen's forces, the Guangzhou Government faced threats from the Beijing regime under warlord Wu Peifu. Hostilities were constant between the GMD forces and the Zhili faction that held power in Beijing.

Political desperation drove Sun to claim a share of Guangzhou Customs surplus. ${ }^{6}$ A pronounced financial strain among Sun's ranks fuelled the desire for reclaiming a pro rata share of the Guangzhou Customs surplus to ease his Government's economic crisis. Sun had been well received during a visit to Hong Kong in 1923 and held some hopes that merchants there would be forthcoming with funding. ${ }^{7}$ But these loans never materialized, and Sun's finances rapidly deteriorated. During this time, Sun reportedly also had to buy the loyalty of his soldiers. To redress this added strain, his regime attempted to squeeze taxes out of all and sundry but with little marked success. ${ }^{8}$ Sun turned to the most readily available source of revenue, the Customs. The Guangzhou Government (on the suggestion of the IG) had previously been accredited 13.7 per cent of revenue through negotiation with the Beijing Government and the Inspectorate of Customs in 1919. ${ }^{9}$ When Sun was forced to flee Guangzhou in 1922 these funds were earmarked and held apart from the surplus under the IG's instruction. 
At this juncture it was not only a pro rata share of current surplus that Sun requested but also access to the funds collected when he had been overthrown. The amount that had been held was Sh. Tls. 2,513,950. ${ }^{10}$ When renewing demands for these funds, Sun claimed that he was simply requesting his government's rightful dues.

The main justification for Sun's claims was based on the pursuit of his government's legitimate right. Furthermore he stressed the need for equity of treatment for what he saw as essentially China's two rival regimes. In a letter to Sir James Jamieson, the British Consul General of Guangzhou, Sun's Secretary of State Wu Chaoshu (Dr C.C. Wu, who concurrently held the position of the Vice Minister of Foreign Affairs in the Guangzhou Government) outlined the background to his government's claims on behalf of the south-western provinces, explaining:

I write in reference to the claim of the South-western provinces for their share of the Customs Surplus. There is no doubt that there is ample surplus remaining after the foreign obligations charged on the Customs revenues are paid and that at present it goes to pay past debts contracted by Peking. It thus sets free other revenues which are employed by the northern militarists to make war against the Southwest. These provinces are then forced to raise funds to meet attacks funded by what rightly are their own monies. They therefore suffer a double loss: loss of funds which should be used for constructive purposes and which, turned over to northern militarists, are actually used to institute war against them, and loss in that for every one of these dollars employed against them they have to raise one or more dollars in self defence. Such a situation is not only impossible but also insufferable. It has been tolerated so long already; it obviously cannot be endured any longer. ${ }^{11}$ [emphasis added]

The Guangzhou Government's claims appealed for fairness, insisting that a great injustice was being committed by denying one regime funds while the other regime was able to access extra funding to make war against its rivals. At the crux of this letter is the inference that by permitting such an intolerable situation continue the foreign powers were in fact failing to remain neutral in political events in China. While the allocation of Customs funds to the Beijing Government might have been an expedient measure only, its ramifications meant the CMCS might be seen as partisan to political events in China.

Wu's letter omitted any discussion of funds available to the Guangzhou Government. The government's access to all of the province's salt revenue was cited as a significant source by both the foreign powers and in press reports. ${ }^{12}$ This was estimated at nearly three million Guangzhou dollars from May to December 1923. ${ }^{13}$ This income was however, insufficient to allow for any expansion of GMD activities in southern China. ${ }^{14}$ The 
Customs was understandably attractive to Sun as a further avenue through which he could access funds. The Guangzhou Customs revenue represented the fifth largest revenue collected in 1923. ${ }^{15}$ British Minister Macleay, however, used the threat of restricting Sun's access to the salt revenue as leverage for the argument that Sun had more than his fair share of finances and therefore did not require a pro rata share of the Customs revenues. ${ }^{16}$ $\mathrm{He}$ intimated that to redress all 'injustices' they should also ensure the Central Government enjoyed a pro rata share of the provincial salt revenue which was at the time at Sun's exclusive disposal.

From the outset Sun's claims against the Customs do not appear as particularly provocative. He had not demanded all of the Custom revenue nor had he threatened the functioning of the Customs house. In the early months of this controversy, Sun voiced no intention of interfering with or intimidating the staff of the Customs administration. He was simply seeking to reclaim a right previously accorded to his government in 1918 and 1919. It is significant that requests laid against a share of surplus previously enjoyed by Sun's Government elicited such a mixed reaction from the foreign powers.

The foreign powers' initial response to Sun's claims was ambivalent. The powers believed that they could employ a policy of procrastination, which had been adopted since Sun first raised the issue in the summer of 1920. ${ }^{17}$ The rationale behind this deliberate stalling was the prediction that an imminent collapse of Sun's government would cause him to again flee and in doing so relieve the need to find a solution to the problem. In the months that elapsed between Sun's renewed claim against the Customs and his ultimatum issued on 5 December 1923, the powers failed to move towards constructive negotiations. The Guangzhou Government expressed frustration at what became a three-month delay in addressing their demands. A statement by Sun on 19 December illustrated this frustration. He wrote, '[s]ave for a bare telegraphic intimation on September 28th that this memorandum was under the consideration of the diplomatic body, no reply was vouchsafed to this Government until the 3rd instant - after nearly three month's delay.' ${ }^{18}$ As the months passed, moreover, Sun's government did not collapse. For the foreign powers action was now unavoidable and the diplomatic body in Beijing sent a telegram to the Guangzhou Government warning that they were prepared to take whatever forcible measures were necessary to protect the Customs. ${ }^{19}$

The tensions surrounding the Guangzhou Customs acted as a catalyst in creating the need to define the CMCS as either a Chinese or foreign concern. Throughout the controversy the powers attempted to disassociate themselves from what they described as purely Chinese concerns. Ironically, though, the powers simultaneously threatened active intervention should Sun attempt to act on his claims. In a personal and confidential letter to $\mathrm{Wu}$, the British Minister R. Macleay sought to clarify what he saw as the Guangzhou Government's misunderstanding of his role 
in relationship to the Customs issue. ${ }^{20}$ Macleay stressed that the CMCS had always been considered as Chinese Government, or rather, national revenue. He concluded that any issues arising as to proportionate distribution of surplus were a 'matter affecting the internal administration of China to be settled by the Chinese themselves'. This letter, however, had a proverbial sting in its tail: 'Whatever the rights or wrongs of your case against the Central Government I must impress upon you that in selfdefence, and for the protection of their interests, the Powers cannot admit any interference with the Customs administration. ${ }^{21}$ No effort is made to veil the threat of foreign intervention. When reading this confidential letter, it is apparent that the Customs controversy was being played out in several arenas, public and private, formal and informal. The Nationalists and the foreign powers appear as the two dominant forces in the negotiations; the CMCS was evident in a passive role. Sun's claims had gone beyond challenging the auspices of the CMCS and were interpreted by Macleay as a threat to foreign interests in China (however, at no stage were the Westerners working for the Customs threatened). So, in this instance, the recognition of the CMCS as a Chinese institution appears confused; Macleay's response alone indicates that he considered the CMCS more than a Chinese concern.

Macleay's threat that the powers might be forced to act in self-defence is indicative of a concern of anti-foreignism. Some newspaper accounts during the controversy meticulously detailed meetings or assemblies by Chinese protesters. One North-China Daily News (NCDN) article in particular wrote of a mass meeting held in Guangzhou on 16 December, reporting that, when the procession approached Shamian, protestors shouted, '[w]e will destroy Shameen and kill the foreigners' ${ }^{22}$ In a later article the Americans were reportedly perturbed by an element of anti-American sentiment evident in Guangzhou. ${ }^{23}$ While in earlier times such threats would have been passed off with a minimum of concern, an act of anti-foreignism in May 1923 had shaken the sense of security the foreigner had held in their privileged position in China.

Until 1923 the privileged position of the foreigner in China had not been placed under threat of great magnitude since the Boxer Rebellion. Isolated reports of brigandage, robberies and attacks on Western travellers and missionaries were reported with regularity, but the scale of the Lincheng incident in May 1923 shook the foreign powers' confidence in their security in China. Bandits held up a train at Lincheng and this act resulted in one Briton being shot dead and 26 other foreign passengers taken hostage. ${ }^{24}$ Macleay reported:

On the 6th May there occurred a brigand outrage, which was remarkable for the unexpected and daring manner in which it was planned as well as for the success, from the brigands' point of view, which 
attended its execution ... it would be no exaggeration to characterise it as one of the most serious incidents which have arisen between China and the Powers since the events of the Boxer Rebellion in $1900 .{ }^{25}$

Although all hostages were eventually released, this incident and its clear anti-foreign motivation unsettled the powers. That bandits were so emboldened to undertake such a large attack to some extent reflected on the lawlessness and militarization of Chinese society during the warlord era. It also signified a lack of fear of foreign retribution particularly as foreigners were deliberately targeted. It is not surprising then, with this incident fresh in their minds, that the powers were concerned about reports of an apparent rise in anti-foreign sentiment in Guangzhou.

The Lincheng incident had a direct influence on the powers' response to the Guangzhou situation. ${ }^{26}$ This brazen attack shook the complacency of foreigners in China and provided the impetus for a defensive reaction by the powers, but in reality they had allowed months to elapse before responding to Sun. An $N C D N$ editorial supported the powers' response to the challenge to the CMCS:

We certainly would not appear to be putting Dr. Sun Yat-sen and the bandits of Paotzeku in the one boat. But it is none the less clear that in combining to prevent his interference with the Canton Customs, the Powers are applying the principles of the Lincheng Note. Their position, a perfectly legitimate one, is no more visibly assailed by a bandit attack on their nationals than by an attempt to seize the Customs or by illegal taxation. ${ }^{27}$

This editorial cast any response to Sun's demands in the shadow of the bandit outrage. This incident was a culmination of increasing brigandage in China, a situation that had long disturbed and frustrated the powers. In response to this attack the diplomatic body issued two notes to the Chinese Government, part of which addressed their concerns for guaranteeing the safety of foreigners in the future..$^{28}$ In the first Lincheng note, the powers stated that if the Government failed to take adequate measures to protect foreigners then the diplomatic body 'would be obliged to consider what further steps should be taken' to protect foreign lives and interests in China. ${ }^{29}$ The diplomatic body's commitment to these principles was tested by the Guangzhou situation.

The powers resolved to defend the Customs. When discussing the demands of Sun's government, they revealed their attitude to the Guangzhou forces. Macleay was instructed by the diplomatic body to 'warn the local Government of Canton' that the foreign powers would not allow interference with the Customs. ${ }^{30}$ By referring to Sun's government as a local government, regardless of how appropriate this may have been, the legitimacy of his claims were immediately questioned. The powers 
remained unconvinced that they were dealing with what might become the national government.

\section{Gunboat diplomacy}

During the Victorian era and even into the early part of the twentieth century, Western powers used gunboats as a mechanism for forcing a resolution to disputes. ${ }^{31}$ Such vessels embodied much of the imperial mentality of the time, most particularly, the paternal and civilizing ideals of the imperial age. The gunboat allowed Britain, in particular, to police its territories, advance its interests and protect its nationals in China. ${ }^{32}$ Gunboat diplomacy, it may be argued, was still evident in the foreign presence in Republican China. The threat of force was a mechanism through which foreign interests could be advanced. Such leverage was exercised to defend the diplomatic body's stake in the CMCS. A foreign naval demonstration was assembled in Guangzhou's harbour to dissuade Sun from taking action against the Customs. This concentration of forces consisted of nine vessels (four British, two American, two French and one Japanese). ${ }^{33}$ During an interview with Sun, Owen Mortimer Green, the editor of the $N C D N$, asked whether he would fight against these forces. Green reported: 'Dr Sun said that he could not overcome such a force, but then he would have the glory of being beaten by all the Powers which he would regard as an honour. ${ }^{34}$ Sun's enigmatic responses in this interview with Green were printed in the $N C D N$ and a paraphrased version also appeared in The Times ${ }^{35}$ Allusions to Sun's desire for martyrdom were also mentioned in British Foreign Office reports. British Minister Macleay expressed concern that Sun was presenting himself as glad to be defeated by Britain as 'she [Britain] would then have made herself responsible for dealing the death blow to democracy in China'. ${ }^{36}$ Sun's emotive comments prompted an increased naval presence the harbour.

By mid-December the foreign naval presence in Guangzhou's harbour had grown to 15 vessels. The nations represented in this collective force were Britain, America, Japan, France, Italy and Portugal. The American representation included destroyers 225, 226, 343 and 346, the cruiser Ashville and gunboat Pampanga. The British assembled their gunboats Tarantula, Magnolia, Bluebell, Moorhen and Robin. The French gunboats, Malicieuse and Craonne, the Portuguese gunboat Patria and the Italianchartered steam-launch Guangdong (manned by Italian sailors) supplemented these forces. ${ }^{37}$ Foreign troops were briefly landed in the foreign settlement in response to reported anti-foreign rhetoric. This display of force effectively stalled Sun's actions but also prompted an anti-foreign backlash from the Nationalists.

The $N C D N$ 's editorial line hotly defended foreign and particularly British involvement in the naval demonstration. A leading article entitled 'A New Policy Needed in China' emphasized the unity of the diplomatic body. The 
article explained that it was merely a question of seniority that determined the representative of the diplomatic body and 'the fact that a British subject presents the foreign communications to Sun's Government is of no more importance than that in Peking a Portuguese subject does the like to the Northern Government'. ${ }^{38}$ The reality of British predominance in the CMCS could only mean that claims of equality of interest, such as those vehemently expressed in the $N C D N$, were superficial. Britain obviously stood to lose more than the other powers should the CMCS be attacked; moreover Britain had always maintained a dominant position among the other powers in China. Rhetoric of unified action, furthermore, was designed to shield Britain from bearing the brunt of any Chinese unrest. An article by George E. Sokolsky outlined China's mistreatment of international treaties and conventions. His tone was unmistakably defensive, writing:

No foreign Power wants the expense and irksomeness of maintaining soldiers and gunboats in China or of exercising extraterritoriality. No foreign Power wants all the trouble of protecting its nationals in China. It would prefer a situation here such as exists, let us say, between Great Britain and the United States, where equals work together for the common benefit. But that is now impossible and the Chinese people are to blame. ${ }^{39}$

There is a sense of moral justification in this article. Sokolsky focused on the duty the British were compelled to perform by virtue of their powerful imperialist status. ${ }^{40}$ This duty, he believed, entailed the maintenance of a military presence in China.

Such sentiments as these were echoed throughout other materials produced during this era. While the height of British imperialism had passed, such imperialistic sentiment still remained evident in commentaries and reports on China. The NCDN, with its 'impartial not neutral' motto alone, represented a bastion of imperialistic values in the East. In matters not of direct concern to British interests, the paper declared itself 'impartial'. In events that directly affected Britain or Britons in China it was 'not neutral'. ${ }^{41}$ Authoritative works such as Rodney Gilbert's What's Wrong With China (1926) urged foreign intervention in Chinese affairs. He wrote:

What is wrong with China and will continue to be wrong with her, is that the Chinese are children, that their world is a world of child's make believe; and that they have no more right, in their own interest or in humanity's larger interest, to govern themselves or shape their own course of education, than pupils in a school have to boss the faculty and to dictate what they will learn and what they will not. ${ }^{42}$

Gilbert explained it as inevitable that China would resent the power (or in the case of the Guangzhou dispute, the powers) that enforces discipline. 
Through moral and physical force, though, the Chinese would be subdued. ${ }^{43}$ This sense of moral duty was also advanced by Sir John Pratt in War and Politics in China when discussing British predominance in Sino-Western relations during the Republic: 'it was the penalty she [Britain] had to pay for greatness' ${ }^{44}$ Although Britain's economic predominance in China was challenged by Japan and America by the mid-Republic, Britain still remained anxious to protect its interests, both economic and political. ${ }^{45}$ The $N C D N$ and similar writings supported British and other foreign interference in China as inevitable, and in fact desirable.

\section{Where was the Service in the Guangzhou controversy?}

Sun's demands in Guangzhou directly embroiled the CMCS. In the months during the Guangzhou Customs controversy, the CMCS was most noticeable by its silence. This is not to deny the centrality of the CMCS to the incident, but beyond the Service being the focus of Sun's claims, there is very little evidence of reaction. The silence of the CMCS gave, by inference, the impression that the Service remained inert in the face of Sun's claims. This is puzzling since, even at the outset, the claims of the Guangzhou Government presented a threat to its integrity. ${ }^{46}$

Aglen's actions throughout the controversy were muted to say the least. Moreover, he was on leave through most of the months in question, with correspondence being handled by Officiating IG Cecil Bowra. Aglen's choice of Acting IG was shrewd as Bowra was older than Aglen and therefore did not see himself as a likely successor to the top job. ${ }^{47}$ There was little possibility then that Bowra would seek to glorify himself to the detriment of the Service. After a long career with the CMCS, Bowra was well equipped to handle the situation that arose at Guangzhou and there was little doubt of his loyalty to the Service and the IG. But the power of office was not entirely with him. The key to the seeming inertia of the CMCS did not lie then with either an avaricious or inexperienced Acting IG, but can be identified in Customs documents. Commissioner A.H. Harris was in charge of the port. ${ }^{48}$ On 9 October Bowra sent instructions to Harris that the concern of issuing the Southern Government a pro rata share of the Customs revenue was 'in the hands of the Diplomatic Body, a decision on it will, no doubt, in time be communicated to that Government through the Dean of the Consular Body in Canton' ${ }^{49}$ While seemingly innocuous, this comment alone encapsulated the Customs' attitude to Sun's threats. The Service was protected by the powers and contented to ride the situation out under the protective gaze of the gunboat flotilla. The powers had shown themselves prepared to physically defend their interests in the Customs and, therefore, the Service could allow the powers to go into battle on their behalf.

The available Customs-based accounts of the controversy share nonchalance in summing up the incident as amounting to nothing more than a dead 
letter. The assurance that the matter of distribution or non-distribution of surplus rested in the diplomatic body's hands allowed the Customs a sense of complacency. Evidence of CMCS apathy is illustrated in a letter between Aglen and Acheson (Non-Resident Secretary (NRS), London). Aglen writes:

Sun Yat-sen had made up his mind, I think, to seize the Custom house with the idea that he would be able to obtain the Canton revenues, and this produced a naval demonstration, and there the matter rests for the moment. ${ }^{50}$

In a later letter Aglen praised Bowra's judgement as Acting IG in having taken a firm stand against Sun. He reflected, 'I was not pressed in any way for revenue funds. ${ }^{51}$ The CMCS was protected by gunboat diplomacy but this was not a lasting solution for the IG or the foreign element of the Service in what became an increasing difficult political climate.

The foreign reaction in Guangzhou can be explored as both an instinctive response after the attack on Westerners in the Lincheng incident and, further, as an example of British determination to maintain its dominance of the Service. ${ }^{52}$ Both interpretations are appropriate, but others may also be drawn from this event. The Custom's ability (and hence the treaty powers' ability, by virtue of their gunboat diplomacy) to either support or thwart Sun's claims has direct impact on our understanding of the agency of political legitimacy in the Republic. In the foreground of the CMCS's decisions were the foreign powers, which, in this instance, had what appears to be the ultimate say over the outcome of Sun's requests. By granting the Guangzhou Government access to the pro rata share of revenue, the foreign powers, through the CMCS, were also tacitly approving this regime. By withholding these funds, therefore, the foreign powers displayed their possession of the necessary leverage, namely control of the CMCS, to influence Republican politics.

In the British Foreign Office Annual Report for 1923, Minister Macleay commented that Sun's return from refuge in the French Concession in Shanghai to the ferment of Guangzhou's power struggles was one of the year's most remarkable events. Even more noteworthy was the fact that Sun managed to reclaim and maintain power without having troops attached to him personally. ${ }^{53}$ By British accord Sun was no longer considered a serious player in the struggle for political hegemony. Western observers who underestimated his tenacity, therefore, had not anticipated Sun's resilience in returning to the fray in Guangzhou. The deliberate policy of procrastination adopted by the foreign powers reflected a belief that, through using diversionary methods, they could negate the threat. The desperation of Sun's situation was widely publicized, and in spite of such compelling evidence that he was once more battling for survival, his claims against the CMCS were initially disregarded as nothing more than rhetoric. 
Throughout the Customs controversy the Western press generally represented Sun in an unflattering light. Thus in London The Times published a report on Sun's lack of credibility. The article described Sun as regarded by all classes in Guangzhou as 'a ravening wolf, devouring the fat and blood of the people in order to sustain his obsession that he is destined to be the saviour of the country'. ${ }^{54}$ In a leading article on the issues surrounding the Guangzhou Customs, the NCDN stopped short of accusing Sun of fabricating or manipulating information but suggested it just the same. ${ }^{55}$ Sun was the focus of many such articles during this time.

A key issue throughout the controversy was the perception of Sun as a failed revolutionary. Among the powers there was a lack of faith in Sun. They no longer viewed him as a force for the unification of China. Painted as a deluded idealist, Sun's claims against the Customs, however justified, were viewed in a light jaundiced by perceptions of his incompetence. Aglen, in a letter to Bowra discussing Sun's failure in Guangzhou, described what he saw as the end for Sun, who had lost command of everything except a portion of the city. Aglen wrote: '[Sun] has no control over his subordinates, and, if the truth were known, he is probably not in full possession of his faculties. ${ }^{56}$ Such reflections indicate that Sun was seen as more of an annoyance than a powerful force in China.

The representation of the events in Guangzhou in December 1923 as a 'Customs crisis' is not unusual. Such terms were bandied about in press at the time and have been readily absorbed into academic treatment of this incident. What may be argued, however, is that the Guangzhou Customs was never really in a position of great danger from Sun; the presence of the foreign gunboat flotilla in fact provided a fait accompli to resolving the incident in Western favour. Sun had control of the Guangzhou Government but only ever held tenuous control over the military. Even with the full support of his forces, it is dubious that Guangzhou's firepower could ever be a match for the well-armed gunboat flotilla. The display of naval firepower was intended to intimidate Sun without resorting to actual use of force, and this is integral to the nature of gunboat diplomacy. ${ }^{57}$ Calling the incidents of December 1923 a crisis is overstating the whole affair. Sun's actions had caused some discomfort on the part of the foreign powers but it is not evident that the diplomatic body had anything but the upper hand in negotiations with Sun. And, most significantly, the CMCS remained untouched by events.

The Guangzhou Customs controversy raises questions as to the role of the CMCS in condoning political legitimacy in the Republic. By extension of this idea these events also allow an investigation of imperialism in China and how the CMCS was used as a mechanism to influence events. The CMCS represented a security for foreign interests and investments in China and therefore threats against this Service were met with resistance from the powers. The defence of the Customs in this instance, while protecting the integrity of the institution also protected avenues for the 
foreign penetration of China. The powers' demonstration against Sun had far-reaching repercussions on the position of the foreigner in China. The Powers had succeeded in protecting their concerns in the Customs but in doing so they had not only provided impetus for the rousing of anti-foreign sentiment in China but had identified the CMCS as a prominent target for resentment.

\section{Anti-imperialism and the CMCS}

You would be amazed at the China which is now confronting us were you here. The foreign prestige bubble having been completely pricked, the Chinese are getting away with things in every direction.

Aglen to Bowra, 20 November $1925^{58}$

Aglen's apprehensive forecast for the future of the CMCS and the foreigner in China was tinged with both incredulity and regret. Comments in similar vein to Aglen's are echoed throughout British accounts from 1925-7. For the CMCS employees and other foreigners in China, the Guangzhou Customs controversy did not fade from mind as an unpleasant incident as it became a forerunner of further unrest. When the May 30th incident occurred in Shanghai in 1925 (see next section), it sparked nationalistic fervour that swept through the treaty ports and elsewhere, presenting an ominous challenge to the security of foreign communities in China. While anti-foreign but particularly anti-British acts and protests were recorded throughout China during 1925-6, focus again fell on Guangzhou. This southern entrepôt became the centre for virulent anti-British protests that were expressed through pickets and the boycott of Guangzhou and Hong Kong and lasted for almost sixteen months. Guangzhou was the traditional base for the GMD and hence their adoption and development of anti-imperialist platforms in the 1923-5 interregnum found expression most readily in this region.

While it may be argued the Guangzhou Customs controversy was resolved to the satisfaction of the foreign powers, their actions had given impetus to the rise of anti-imperialism in GMD ideology, which no amount of foreign gunboat demonstrations would be able to stem. Ironically a defeat for Sun and his Guangzhou Government had turned the tide against the treaty powers in China. Although seen by the West as a discredited political leader, Sun's strength lay in his ability to use the symbolism of his stand against the foreign powers to arouse the support of the southwestern populace. ${ }^{59}$ Moreover it was only after the Guangzhou Customs controversy that Sun began to develop his ideas of China's 'subcolonial' status and presented imperialism as the root of all of China's problems. ${ }^{60}$ At this time the GMD had entered into a closer allegiance with the Soviet Bolsheviks and the CCP and it was this collaboration that brought the concept of imperialism to the fore in GMD thought. ${ }^{61}$ The events 
surrounding the Guangzhou Customs house can therefore be interpreted as representative of China's experience with the foreign powers. In this the Guangzhou Government, representing the forces for democracy and reform in China (as opposed to the reactionary and tradition-bound northern militarists), was seeking its due recognition in the form of CMCS revenue. Thus the CMCS and access to its funds were tied to the growth of democracy in China. The foreign gunboat flotilla was moving to crush not only Sun but Chinese nationalism, the emergence of which would have threatened their privileged position. The unity of the foreign powers in this action reflected China's domination by many powers. This interpretation has some basis in Sun's interpretation of China's subcolonial status. The heavy-handed approach of the powers to Sun's demands was detrimental as it merely gave him more justification to speak against imperialism in China. It gave Sun a focus for rallying against the foreign presence in China. Sun's San Min Zhuyi (The Three Principles of the People), presented as a series of lectures in 1924, articulated the need for the Chinese people to struggle against foreign privilege in China. ${ }^{62}$

Anti-foreignism was not a new phenomenon in China. Popular uprisings such as the Boxer Rebellion, the 1911 revolution and the May Fourth Movement were in part a response to China's failure to modernize and, simultaneously, a protest against foreign encroachment and the imposition of the humiliating Unequal Treaties. Anti-foreignism can be best understood as an often irrational, emotive sentiment, rather than an ideology, which was often aroused to achieve short-term political benefits. ${ }^{63}$ Without any guidance or ideological anchoring, such sentiment could be volatile and rapidly run out of control. The united front formed by the GMD-CCP had antiimperialism as one of their common platforms. In this sense they harnessed radicalism by focusing anti-foreignism to opposing foreign exploitation and oppression. Such oppression was most readily evident in the existence of the treaty ports. That is not to say then that anti-foreignism and antiimperialism are one and the same thing; rather anti-imperialism harnessed and gave direction to the popular resentment of foreign impositions.

In Sun's January 1924 outline of the GMD's political manifesto, the first statement is particularly significant in revealing how the Nationalists had adopted anti-imperialism as a guiding principle. In turn this had direct implications for the future of the CMCS. It read:

All unequal treaties, such as foreign concessions, extraterritoriality, foreign control of customs, and all sorts of political power exercised by foreigners in China and prejudicial to her sovereignty, are to be abrogated and new treaties negotiated on a basis of equality and mutual respect for each other's sovereign rights. ${ }^{64}$

Clearly the CMCS, with its foreign Inspectorate and treaty port origins, constituted a visible affront to the GMD. Most particularly it represented 
an imposition by foreign powers and leverage for foreign interference in China's affairs. The other points in the manifesto covered the revision of treaties that were harmful to China; the responsible financing of loans; that the Chinese people should not be responsible for the loans contracted by irresponsible Beijing regimes; and the need to explore how to throw off foreign loan debts and to free China from its subcolonial status. ${ }^{65}$ Of all of these points the first was the most radical ${ }^{66}$ and, in addition, it presented the best possibility of inciting anti-imperialist action among the population.

\section{The Guangzhou-Hong Kong boycott of 1925-6}

So far the customs revenue has been able to withstand the rapacity of the Tuchuns, ${ }^{67}$ a fact solely due to its being rigidly under foreign control and collected at the ports where foreign warships if necessary, afford protection.

Miles Lampson ${ }^{68}$

A recurring theme throughout this chapter is the connection between gunboats and Customs revenue. Less specifically the association lies between the functioning of this (Chinese) fiscal organization and the threat of foreign force being employed to maintain it. The surfacing of this link serves to illustrate the Customs close alignment with the imperialist presence in China. In 1923 a fleet of foreign gunboats was assembled to protect the Guangzhou Customs and yet by 1926 the British were alone in their desire to commit to active protection of the Service. By 1926 the most immediate deterrent for the powers was a fear of being targeted by the virulence of anti-foreignism. The emerging resentment against foreigners expressed itself most threateningly in the outbreak of strikes, boycotts and demonstrations stemming from the May 30th incident of 1925. The British bore the brunt of this violence and any symbol of British influence in China was targeted. The CMCS was a highly visible reminder for the Nationalists of not only foreign interference in Chinese affairs but, more specifically, of British interference in China.

The May 30th incident was the result of ongoing unrest between Chinese workers and Japanese mill owners in Shanghai. Demonstrations intensified throughout May and on the 30th the foreign settlement was the focus for an extended protest. A student demonstration in the Nanjing Road vicinity swelled its ranks from 300 to over 2,000 protesters and had become, according to Police Inspector Everson, very menacing in spirit; protesters began calling 'Kill the foreigner!'. ${ }^{69}$ In response to this ominous gathering, members of the Shanghai police (comprising European and Indian officers) fired into the crowd, after a brief warning. They killed four protestors instantly, mortally wounded five and injured another fourteen. This heavyhanded response by the settlement's police became the focus of further strikes and unrest. The British Foreign Office Annual report noted: 
it began to be generally realised that the disturbances of the 30th May had by now completely lost their original character of a mere student demonstration and were becoming metamorphosed under the skilful promptings of the Soviet and Kuomintang wire-pullers into a purely political movement involving a definite challenge to foreign life and property throughout China. ${ }^{70}$

A state of emergency was subsequently declared in the Settlement. After an unsuccessful diplomatic inquiry in June, a judicial inquiry in October found that the officers had little choice but to fire. A compassionate grant, however, was given to the wounded and the families of those killed. By the end of the year it appeared that disturbances and protests in Shanghai had subsided but reactions to these events spread throughout the treaty ports.

The May 30th incident sparked off protests and boycotts throughout China. During June and July there were few towns of any size that did not respond to the incident in some way. ${ }^{71}$ The incident in Shanghai served as a catalyst for a surge of anti-British expression and nationalistic protests against foreigners in China. In such an emotive environment it is quite conceivable that any grievance could be blown out of proportion; local and isolated incidents were swept into the May 30th incident. ${ }^{72}$ In Beijing demonstrations and processions by students became a daily occurrence and Britain was the subject of violent press attacks. ${ }^{73}$ The $N C D N$ ran constant reports on the unrest, detailing riots, strikes, attacks and outrages committed against foreigners. ${ }^{74}$ As a reflection of the climate of fear, the paper reported rumours that the Chinese were manufacturing poisonous gas and had brought in German and Russian chemists to assist them with this insidious scheme. ${ }^{75}$ This report both hinged on foreigners' fear of further Chinese attacks and also revealed a preoccupation with the Soviet threat against foreign interests in China. The $N C D N$ openly blamed the CCP and the Nationalists' association with the Soviets for having fuelled the volatile climate of strikes and protests. An editorial reads:

our quarrel is not with China. Our quarrel is with the destructive force of the 20th Century, the germ that is polluting our great cities, the beast that has come out of the dark forests of Russia to disrupt and corrupt the civilization of the universe, Bolshevism. Against this dreadful plague the civilized world must stand united. ${ }^{76}$

Britain and the other foreign powers were, in accordance with the above excerpt, not standing firm to aggravate or thwart Chinese nationalism but they were defending civilization as a whole against the Bolshevik threat.

The CMCS was affected in the reaction to May 30th and in some instances difficulties extended beyond that of the original incident. Hankou is a prime example of such prolonged unrest. On 6 June there were anti-British demonstrations and only five days later these protests turned violent, with rioting 
and mob attacks against foreigners. ${ }^{77}$ A landing party from the HMS Gnat succeeded in driving back the crowds without resorting to use of firearms. A voluntary international force was mobilized to protect the foreign concession. ${ }^{78}$ The Customs house was defended by British troops. ${ }^{79}$ This unrest culminated in the British retrocession of leased territory, an unexpected windfall for the Nationalists. ${ }^{80}$ Settlement of outstanding land issues (including the Customs house at Hankou, which encroached on to British leased territory) remained, however, an ongoing concern even in the early 1930s ${ }^{81}$

Hong Kong became the focus of a strike by Chinese workers. In the months prior to the May 30th incident, Hong Kong authorities had already harboured concerns over the militancy of Chinese workers' unions. ${ }^{82}$ The events in Shanghai added a further dimension to anti-British sentiment and by 19 June the strike had begun. Propaganda secretly printed and circulated throughout the colony urged workers to leave Hong Kong and to travel to Guangzhou. As a result there was a mass exodus of Chinese as workers and students alike travelled to Guangzhou. ${ }^{83}$ Trade was crippled. A volatile clash during a protest in June near Shamian, Guangzhou's foreign enclave, exacerbated existing tensions and galvanized the strikers into further boycotts against British trade and Hong Kong. While Hong Kong authorities had optimistically forecast a speedy resolution to the strike, by July there was every indication the boycott would be a protracted standoff.

By early June the Guangzhou Customs had taken defensive measures against possible unrest. The Customs house had been closed by the Commissioner, Edwardes, and remained closed in the face of disturbances following the May 30th incident. ${ }^{84}$ All office work had been removed to the Assistant's Mess on Shamian. ${ }^{85}$ In a report by Schjoth, the Acting Deputy Commissioner of the Guangzhou Native Customs, Shamian was 'fortified with trenches and barbed wire all round, with volunteers on duty day and night' ${ }^{86}$ The majority of foreign women and children were removed to Macao under the care of Commissioner Le Bas. All private and official Chinese servants had left their positions. On visiting Edwardes to report on the situation, Schjoth noted that Commissioner Bell from Hong Kong was also present to discuss the growing tensions ${ }^{87}$ This meeting was an indicator of the seriousness of the situation.

The Guangzhou-Hong Kong boycott was pre-empted by the response to the events in Shanghai. In Guangzhou the 'smouldering embers of antiforeign hatred were ever ready to be fanned into flame' 88 and on 23 June at Shamian a demonstration escalated into a violent exchange of fire with serious repercussions. Both British and French troops on Shamian had been prepared for defensive measures in response to a march planned to pass alongside the foreign settlement. The march, however, led to a clash between the foreign troops and the protesters. It remains unclear who started firing but the Shaji bridge incident resulted in the deaths of at least 37 Chinese and one foreigner with several wounded. ${ }^{89}$ The muddiness surrounding actual details of the exchange is reflected in press accounts. 
The NCDN shifted blame away from the Chinese and the British and French troops, instead blaming Bolshevik forces for inciting the violence. It reported the 'Detestable Trick of the June 23 Outrage: Schoolgirls Massed in Parade While Russians Shot from the Windows to Provoke Foreigners into Firing, ${ }^{90}$ These events became the catalyst for an intensifying of antiBritish feeling in Guangzhou and for protracted boycott of Guangzhou and Hong Kong that extended for almost 16 months. ${ }^{91}$ Anti-British feeling ran high during this blockade.

As investigations into the Shaji incident foundered, a blockade came into force. On 13 August the Strike Committee issued three new regulations with the tacit approval of the Guangzhou authorities. These stipulated: all steamers, except those of British and Japanese nationalities, were permitted to take part in coastal trade, provided they do not call at Hong Kong; all vessels, on entering port, must be inspected by labour pickets; and export of raw materials and food-stuffs was prohibited. ${ }^{92}$ As indicated in the first instance, Britain and Japan were both targets of the boycott; restrictions against the latter, however, were only a formality and lifted within a matter of days. ${ }^{93}$ The regulations that involved inspecting vessels directly infringed upon the mandate of the CMCS and would inevitably lead to tensions.

As it unfolded the Shaji incident had direct repercussions for the Guangzhou Customs. Prudently steering clear of direct involvement, Commissioner Edwardes and other staff had secured a vantage point for watching the procession from the Customs Mess window. ${ }^{94}$ When fighting erupted, however, Edwardes was shot in the knee by a stray bullet. As a result of this injury he was promptly removed from the Customs house and his Deputy, Talbot, took charge. Later Edwardes was commended by IG Aglen at a time when many Customs houses had suffered as a result of the ongoing unrest since the May 30th incident. Aglen commented:

The conduct of those concerned has been worthy of high praise, and I wish to convey to them especially my appreciation of their patience and courage in the most arduous circumstances that prevailed. The wounding of the Canton Commissioner, Mr. Edwardes, by a stray bullet while he was on duty and engaged in measures for the protection of his staff, which necessitated his withdrawal from Canton, was deplorable, but I am glad to find that instances of personal injury to life or limb were rare. ${ }^{95}$

In this circular Aglen also discussed the hardships endured by Customs employees who were deserted by the wholesale strike of their Chinese servants. Schjoth's account details the loss of Chinese servants in Guangzhou; he reported they left without receiving pay as they believed 'they would return as masters' ${ }^{96}$ While the loss of servants was hardly a threat to the functioning of the Service, it meant daily hardship for staff 
as their households ground to a halt and it heightened the sense of crisis gripping the foreign enclaves.

The outdoor staff fared worse than their indoor colleagues and had been chased from their quarters. They managed to keep some of the river launches running without Chinese crew. ${ }^{97}$ The Superintendent of Customs and Acting Commissioner Talbot reopened the Customs house on 28 June with police protection. ${ }^{98}$ Hayley Bell took up the post of Commissioner. As the situation in Guangzhou was severely strained a capable Commissioner was required. Throughout the boycott and pickets, Bell continually showed he was a strong leader, determined to protect the Customs. In an unusual move Bell, who had formerly been in Hong Kong, arrived with two of his young children and his Chinese servants: 'no doubt he thought a baptism of fire would be excellent training for his children and teach them to face danger with fortitude'. ${ }^{99}$ In contrast, most Customs wives and families had been removed to Macao prior to the Shaji incident. Possibly, Bell's military background had toughened his nerve in such trying situations (Bell had distinguished military service during the First World War, rising to the rank of Colonel).

When patrolling the Shamian Bund, Bell opted to wear his military uniform, although such dress was not what might have been expected of a civilian Customs Commissioner. ${ }^{100}$ In Hewitt's account, Bell was described as 'a tall slim figure, handsome in uniform, a 1914-18 steel helmet, khaki jacket emblazoned with medal ribbons, fawn breeches and riding boots, a 4.5 pistol in a holster'. ${ }^{101}$ This description of Bell is noteworthy as he was ostensibly a servant of the Chinese Government and yet was patrolling the Shamian Bund in full military regalia. In other accounts of the unrest in Guangzhou, CMCS staff took up arms for self-defence but there was never any mention of them patrolling the Bund or reverting to military dress. ${ }^{102}$ It is possible that Bell may have joined a voluntary militia but this is purely speculative. This use of military uniform and the symbolism of military apparel may have been readily acceptable in places like India or British Malaya, but Guangzhou was not a British colony. To find Bell in military mode as Commissioner might have added to tensions in Guangzhou, and fuelled resentment against himself and the Service. According to Yvonne King's recollections moreover, Bell's choice of military attire did not find support among CMCS staff. In fact he was considered foolhardy in choosing to wear his uniform. ${ }^{103}$ In what was already a volatile situation Bell's parading of military garb was inappropriate and provocative.

While not directly interfering in the Customs administration, pickets stopped vessels after their examination at the Customs house with the purpose of extorting further funds. In some instances the Strike Committee would carry away 'enemy goods' from the ships directly to their headquarters. These goods would then be disposed of at a profit. The CMCS was unable to control or monitor these goods. ${ }^{104}$ On 6 February 1926 an 
even more serious threat to the functioning of the Service occurred when the Strike Committee seized five boats that were heading to the Customs house for examination. In response to this threat Bell resorted to personal intervention. In a letter to Amery, the British Secretary of State, Governor Clementi of Hong Kong recounted the events surrounding Bell's success in regaining control of these vessels: 'He [Bell] with his Chief Tide surveyor and some Chinese Tidewaiter literally "sat on" these boats for ten hours until they were surrendered to him by the strike pickets. ${ }^{105}$ Such confrontational behaviour could not have been carried out if Bell did not have the security of extraterritoriality and a tenacious character. Bell not only enjoyed this success, but through threatening to close the port to trade he lessened the possibility that the integrity of the Customs would be compromised.

In what was seen by the Western press as an omen of times to come Bell was the victim of an attack by strike pickets on 22 April. The NCDN reported the incident under such headings as, 'Lieut.-Col Hayley Bell Assaulted. Attack By Strike Pickets Armed With Bamboos' ${ }^{106}$ This attack was presented as a typical example of the lawlessness condoned by the Guangzhou Government through their inaction in curbing the pickets. Bell was a victim, but at the same time it should not be forgotten that he had no doubt inflamed resentment through his choice of military garb for patrolling the Shamian Bund and his direct challenges to the Strike Committee. He was reported as being set upon by the strike pickets when he was 'walking quietly from his office to the Shameen simply with a rain coat over his arm'. When Bell resisted a picketer's attempt to snatch the coat, a tussle broke out and 'without warning the Commissioner was set upon and beaten unmercifully by a gang of five or six men armed with sticks and bamboos'. Bell was knocked to the ground. The $N C D N$ declared, 'It seems quite possible that murder would have been done had not a foreigner on Shameen who

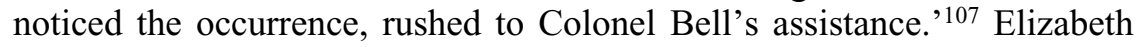
Bell witnessed the attack on her father. The assault was described in detail:

Suddenly he was viciously attacked, brutally beaten with bamboo poles, his helmet knocked off, his head smashed by rifle butts, cut by swords, thrown defenceless to the ground, kicked and left there like a dead animal. ... Chinese Customs officers rushed to his aid, picked up the unconscious, frail, limp body and carried the bleeding man to the Consulate. For days he lay unconscious and temporarily blind, suffering greatly from severe head wounds. ${ }^{108}$

The viciousness of the attack is constant in both this account and the press reports of the time. The extent of Bell's injuries were unclear but according to both sources he was badly injured. In Hewitt, Bell was described as being unconscious and temporarily blind for days, suffering from severe head wounds. ${ }^{109}$ The attack on Bell had dual significance: not only was he a British national but, more importantly, he represented the CMCS. 
After such graphic accounts of Bell's beating it is surprising to discover that his injuries were, at his own admission, only minor in nature. It is possible that Bell wanted to underplay any real injuries but, had his injuries been serious, it is likely the press would have run follow-up stories on his condition. Further to this in a letter to Sir Cecil Clementi, Bell related his version of events that casts a different light on the representation of the attack. ${ }^{110}$ In his view, reports on the affair were much overdone. Bell recounted:

This is what occurred: I resisted personal search by the Pickets at the French bridge (as I always do and always will). When grabbed, I hit him and two then attacked me with sticks two more coming from behind with carrying poles which they took from coolies. I was quite happy even so and had disposed of two; but after two blows on the head I could not see and fell back in the direction of the gate where they dragged me in. I did quite as much damage as I received and I never fell nor did anyone come to my assistance. In the end there were eight or ten at me and they were in each others way - I went back 2 hours later the same way and they left me alone. ${ }^{111}$

Bell concluded that the overall impact of this affair was good, as he had received apologies from the strike pickets and police detectives were now manning the gate. From this account, there is the sense of the inevitability of such a clash. But whatever the personalities of this case, it remains a significant encounter as the CMCS was facing a strong challenge from the Nationalists, primarily through their inaction in moderating the Strike Committee. Furthermore Bell's letter provides a reflection of the uneasiness that the foreigners remaining at the port were experiencing.

While foreign CMCS staff were in most instances safe from attacks by the picketers, Chinese staff of the Customs were prime targets. They were subjected to both intimidation and physical attacks were made against the Chinese staff and Bell wrote of this to Clementi. ${ }^{12}$ Although the letter does little to hide a desire for a sense of high drama, Bell's response to these attacks was to characteristically tackle them head on. He explained that he was virtually 'under siege' in the Customs house and commented that the Strike Committee had for months been 'capturing my men in twos and threes and taking them to strike headquarters and the Tung Yuan where they have generally tortured them'. If power could not be brought to bear on the Committee, Bell recounted that he went on several occasions 'to the Tung Yuan and just sat there until they got worried about me and let them go'. ${ }^{113}$ While it is difficult to ascertain what Bell meant by his staff being 'generally tortured', it is made amply clear that all Chinese staff were under threat of physical violence because of their association with the CMCS. From his description of his response, it is evident that Bell was relying on his extraterritorial status as a foreigner to protect his 
Chinese staff. The methods he employed appeared to be rather unorthodox and dangerous but they were successful in keeping the majority of the Chinese staff safe from the ire of the Strike Committee.

The Guangzhou Customs not only encountered external pressures but also internal challenges to its functioning. Problems emerged with some of the Chinese outdoor staff. Bell was obliged to dismiss two men who were leading figures in a Customs union that was created during the boycott. These union leaders, the chief carpenter and his mate, were exerting pressure over other members of staff to join through intimidation and acts of violence. Bell approached Sun Fo of the government and the Superintendent of Customs warning them that 'the Customs will have no Union and that I shall dismiss if it be necessary every man on the staff outdoors until they understand this'. ${ }^{114}$ Bell's firm stand against demands to have the workers reinstated was in response to his perception of the main issue at stake. The crucial issue for him was not whether men would or would not serve the Customs (as many men worked without problem) but rather:

the far more important question at issue is whether or not a Commissioner is to be defied by a group outside the Customs calling itself a union. ... I believe I am right in saying that no government department in Canton permits such a union against itself to exist and I assert that the Government should not have permitted a Customs Union. As I read my duty this administration does not and will never recognise a Customs Union. If one exists I prefer to meet it now once and for all. ${ }^{115}$

Bell's stand on this issue was a definitive one and he declared he would only reinstate employees if the union was declared illegal and the men were prepared to resume work. The CMCS was a symbol of foreign influence in China, but throughout Bell's letter the image of the Customs as a Chinese institution is emphasized. In this way Bell was seeking to assert his authority not as a foreigner but as a servant of the Chinese and in doing so to keep his position tenable.

\section{Commissioner Bell: lone defender of the Service?}

This account of the Guangzhou Customs during the months of the boycott was not intended to be a critique of Bell's ability to handle crises. His tenacity, however, in protecting the Customs is quite apparent throughout all accounts from this time. While the wisdom of his actions was sometimes questionable (there was always the underlying possibility of a more serious attack on the Commissioner), it is surprising that he acted at all. In the 1923 Guangzhou Customs controversy, the Commissioner remained practically invisible throughout the threats and counter threats, but, in this instance, Bell played a dominant role in events. It may be conjectured that had the Customs still enjoyed the protection afforded by the foreign powers 
and expressed through gunboat diplomacy, there would never have been a necessity for Bell to be boarding and reclaiming ships, rescuing Chinese staff, and scuffling with representatives of the Strike Committee. Aglen reflected on the changing of fortunes of the CMCS:

We have hitherto weathered every storm but we have depended to a large extent on a foreign prestige which no longer exists. I have never believed that the foreign anchor alone would hold us and I am now even beginning to be doubtful whether the Chinese anchor will be strong enough - time only will show. ${ }^{116}$

There is little doubt that the foreign prestige that the CMCS most heavily relied on was that of Britain. As British prestige in China was under attack, the IG was facing the realization of a turbulent future for the Service exacerbated by a lack of tangible foreign support in an increasingly volatile political climate. Aglen's concern also related to an apprehension of the GMD and possibly a premonition that the growing control of the Nationalists would disrupt the CMCS.

When the CMCS was faced with a threat, the role of the IG was vital in guiding the institution through its difficulties. Aglen's leadership was not always apparent. The inaction and sometimes absence of Aglen during the Guangzhou-Hong Kong boycott was similar to the 1923 Guangzhou Customs controversy. Apart from the actions of Bell, little can be detected of the Customs reaction. Throughout the boycott Aglen was absent more often than he was in office. ${ }^{117}$ While an Acting IG was appointed, this recurring void of leadership points to a need to question the effectiveness of Aglen as IG in what were the final years of his administration. The absence of the IG has several possible implications: first, that Aglen was simply unlucky in his choice of travel times; second, he may have become complacent with regard to the security of the Service. There is the suggestion that Aglen was not a well man. ${ }^{118}$ If this was indeed the case, it indicates that Aglen should have realized the need to relinquish his position to an able successor. Ill health may account in part for the fact that Aglen's Z Letters during the 1924-6 period are filled with pessimism over what he perceived as the demise of foreigners in China. He may have felt he was no longer capable of coping with the Nationalistic China he was now seeing. Also, within a semi-official circular, his tone shifted between trepidation and admiration for what he saw as the beginning of the 'real revolution' in China:

It will at once be apparent to all that the situation which confronts the Service to-day is in no way parallel to the situation of 1911-1912. Ground which for decades has seemed as solid as a rock is crumbling in all directions; labour has become articulate, if not vociferous, and 
is making demands which are calculated seriously to interfere with Service discipline; national aspirations are difficult to reconcile with the foreign Inspectorate system; and the Service is of course involved in a wave of anti-foreign feeling which has been evoked for the purposes of political propaganda. ${ }^{119}$

Clearly Aglen's concern was how the CMCS could weather these changes. It must be borne in mind that by 1926 Aglen had filled the role of IG for 16 years, of which the last few years were under trying circumstances. Aglen's absence from events surrounding the Guangzhou boycott may simply be a reflection of a personal crisis, his having little energy left to devote to his position as leader of the CMCS. Aglen's absence at a crucial juncture is apparent again in 1927, when, ignoring urges from Lampson, the British Minister, to return to his post, Aglen was dismissed by the Northern Government. ${ }^{120}$

As the boycott stretched out for months the British found themselves the focus of GMD demands for a judicial inquiry to determine responsibility for initiating the Shaji shootings. While French troops had also been directly involved, the Nationalists marginalized their participation. The sense that Britain was being made a scapegoat for the incident caused a defensive reaction from British representatives. Acting Consul General in Guangzhou, Brenan, detailed his negotiations with the Nationalists for a settlement of the anti-British boycott and among these discussions was mention of French involvement. Brenan drew the Nationalists' attention to the fact that French concessions formed part of Shamian and that French forces had been equally as involved in the incident. His reasoning for shifting the focus to French complicity in this incident was that it was both unjust and illogical for the Chinese to hold a judicial inquiry without the French also present. In an almost hopeful tone Brenan stated that French evidence was essential, and 'they might conceivably be found to blame'. ${ }^{121}$ Newspaper articles throughout this time reflect this sense that Britain was being isolated by the diplomatic body and was devoid of anything more than tacit international support. Editorials entitled 'Will Britain Stand Alone?' and 'The British View of China' both possessed defensiveness in their content, reflecting the pressure British interests in China were experiencing. ${ }^{122}$

Throughout the Guangzhou-Hong Kong boycott not only was Britain bearing the brunt of anti-imperialist attacks, it was also very much alone when considering any action to bring the boycott to an end. GMD offers of ending the boycott with the financial assistance from Hong Kong in paying wages for the strikers was rejected by a frustrated Brenan as nothing short of blackmail. ${ }^{123}$ Ultimately the British followed a policy of riding out the unrest as they realized that alone they were unable to contemplate any decisive action. A secret telegram from the Secretary of State Sir W. Tyrell to British Minister Macleay reported on the China issue as discussed by the Committee of Imperial Defence: 
As regards China generally, offensive action on a large scale is not possible for the British Empire acting alone, and finality could not be hoped for from any operation within our capacity. Offensive action on a large scale can only be international, and even on that basis it would probably be unprofitable. ${ }^{124}$

As a result, British Foreign Office approaches to the United States to sound out the possibility for joint naval action in seizing the Strike Committee's boats in September 1926 (the boycott was lifted the following month) were unsuccessful. Mr Kellogg replied with regret that his government was 'not in a position to associate itself' with the action contemplated by the British government. ${ }^{125}$ Macleay commented that there was no doubt the other powers were little interested in what was happening in Guangzhou. As they were not being affected they had little compulsion to help Britain relieve Hong Kong's discomfort. ${ }^{126}$ The boycott had proved successful in isolating Britain and as the other powers did not want to be similarly targeted they were effectively discouraged from taking any supportive action. For Britain a lone military offensive was not feasible.

When the boycott was finally lifted in October 1926, it was on the condition of a surtax being accepted. Authorities were to levy a special consumption tax of 2.5 per cent on ordinary imports, 5 per cent on imported luxuries and 2.5 per cent special production tax on exports. ${ }^{127}$ This special tax was in reality a realization of the Washington surtax that had not been put into action. British policy was inclined to simply accept this in exchange for an end to the anti-British boycott. This acceptance, according to Aglen, directly affected the CMCS, and unless the tax was approved by all the powers it could not be implemented except with force. In response to this delay the GMD established a rival Inspection Corps to enforce the surtax. This Corps was disbanded when the powers agreed to honour the taxes conditional on the CMCS handling them. Pratt of the British Far Eastern Office reasoned:

His Majesty's Government have decided to acquiesce in these new taxes and to favour assistance being rendered by the customs solely because that seems to be the only means of terminating the boycott and because the price we are called upon to pay is not too heavy. ${ }^{128}$

This was an opportunity for the CMCS to develop its relationship with the GMD, which had often been tenuous. Up to this time the IG had remained in Beijing and was responsible to the Northern Government. Aglen did travel south in order to contact the GMD leadership, especially concerning the Customs at Hankou. This, however, gave the Beijing coalition the pretext to dismiss him from office. The period 1926-7 was extremely sensitive politically for Aglen. Any recognition of GMD forces was immediately interpreted by the northern forces as a deliberate taking of sides and 
therefore provided the Beijing regime with the pretext it needed to remove Aglen from office. Aglen had often written of feeling besieged by Beijing's demands but had refused to be drawn into their schemes. Because of this he would have earned their resentment.

The Guangzhou-Hong Kong boycott marks a turning point for the CMCS in the Republic. Prior to this the Customs had enjoyed the highly visible and arguably effective protection of international naval forces. Shortly after the end of the boycott Aglen was dismissed, thus bringing to an end 17 years of Customs administration. The rise of anti-imperialism and the virulence of anti-British actions that swept through the treaty ports after the May 30th incident sounded warnings for any foreign power that was approached to lend assistance to Britain during the 16-month blockade. By drawing on anti-Bolshevik sentiment in the West, Britain attempted to unite the other foreign powers behind them. In doing so Britain maintained it would not only defend its place in China but would weaken the Soviet influence in the GMD.

Throughout this chapter, the close connection between the Customs and the foreign powers, but most particularly Britain, is evident. While protected by foreign military force, in the form of gunboat diplomacy, the Service took an almost passive role in the 1923 Customs controversy. It was not the CMCS but the treaty powers headed by Britain who were instrumental in defending the integrity of the Service. The use of gunboat diplomacy, while initially effective, fuelled the anti-imperialist spirit of the Nationalist movement and, after being confronted by the intensity of antiforeign backlash, there was a distinct reluctance on the part of the powers to stage any further demonstrations of military force in Guangzhou. By 1925 political conditions had changed and the GMD emerged as serious contenders on the national stage. During the Guangzhou boycott, the Customs house was active in defence and, in large part as a result of Bell's leadership, was a significant force to be reckoned with. For the CMCS, the 1923-7 period marked the end of a sheltered existence and of being protected by the treaty powers. Instead the Service was forced, to all intents and purposes, to stand alone. The CMCS was no longer able to sidestep China's political turmoil. It had become a potent symbol of foreign influence in China and the success of the Northern Expedition had far-reaching consequences on the Service. 


\section{Nationalist ascendancy and the politics of being Inspector General}

In old days one could have thumped the table, mobilized the fleet and even threatened to withdraw from Peking. Nowadays things are very different.

Miles Lampson ${ }^{1}$

The above comment conjures wonderfully lucid imagery of Lampson pounding the table until his crockery rattled, while exclaiming over the China situation. This whimsical reference, however, points to recognition of the changes that were forcing a recasting of Sino-Western relations. The Nationalists had embarked on the Northern Expedition and their early successes brought forth mixed reactions from the foreign powers, whose main concern was the maintenance of their privileged position in the treaty ports. Lampson's reflection reveals the British realization that the era of gunboat diplomacy was drawing to a close. Aglen's dismissal in early 1927 precipitated a succession crisis. The leadership imbroglio served as evidence of the deterioration of Britain's position in China. The struggle for the Inspector General's (IG) position that was waged from 1927 to 1929 served to highlight that the use of diplomacy, veiled threat and coercion were no longer effective in protecting and promoting British interests in the Service or elsewhere.

\section{The dismissal of Inspector General Aglen}

Leading up to his dismissal, Aglen had been placed under increasing pressure from the northern militarists to release extra funds, in the form of approved loans, for their ventures. In a letter to Bowra, Aglen discussed what he saw as a deliberate persecution being waged against him by the disgruntled finance minister. ${ }^{2}$ Rather than merely a clash of personalities, the IG saw the issue at stake as being much greater:

There is no income of any kind except the Customs income and it becomes a question as to whether the Customs income is to continue 
to be devoted to maintaining credit and acknowledged obligations or whether these are to be thrown to the winds and the whole question of revenue thrown open. ${ }^{3}$

This extract reveals that the threats to the Customs houses, which occurred in the aftermath of the May 30th incident and the Guangzhou-Hong Kong boycott, were indicators of a deeper crisis for the Service. The CMCS was being pushed to change its fundamental position in Chinese affairs, a move that Aglen was resisting. Aglen took on an embattled tone as he described his response to the threats posed:

The only thing for me to do is to retire into my shell and sit tight. No money that I control can be got without my signature. The Chinese Government cannot get my signature against my will. The only way in which money could be got would be to relieve me and obtain somebody else's signature and they are not yet prepared to take this step. When they are prepared to do so of course they will do so, and they will have to accept the consequences which would be in many directions very serious. ${ }^{4}$

Such pressures being placed on the IG may account to some extent for his relative silence during the crucial Guangzhou-Hong Kong boycott. Aglen gives the impression that he believed that he was struggling to maintain not only his position but also the future direction of the CMCS.

Aglen's dismissal by the Central Government came at a crucial juncture for the CMCS. The Central Government was pressing Aglen to order the collection of surtaxes in all ports and maintained that, as the Inspectorate was answerable only to the north (Beijing), their orders must not be challenged. While negotiating the proposed collection of these surtaxes, Aglen came under renewed attack from the Central Government who were clearly unhappy with his travelling to Shanghai. Lampson discovered that it was Zhang Zuolin's intention to dismiss Aglen and advised strongly against this. At the same time he urged Acting IG Edwardes to telegram Aglen to 'return from Shanghai and face the music'..$^{5}$ Aglen, moreover, knew nothing of the threat of dismissal until 29 January and then contacted Edwardes (Commissioner in Guangzhou 1926) for more information. Lampson expressed the suspicion that Aglen did not want to remain IG. He hypothesized, '[r]eal trouble is I believe that I.G. would only be too pleased to resign and get out of this mess here'. ${ }^{6}$ Lampson made several requests for Aglen to return to Beijing, all to no avail. ${ }^{7}$ He chose to remain in Shanghai to talk with bankers as he considered it vital to what was happening in the north. Aglen's dismissal was declared on 1 February 1927.

In an official circular discussing the circumstances surrounding his dismissal, Aglen rationalized his actions as an attempt 'to prevent if possible, disruption of the service' ${ }^{8}$ He reflected: 
I desire to express my deep regret that I have been compelled to relinquish the helm at such a critical time, and I wish that my departure could have been contrived in a manner more befitting the dignity of the great institution which for 70 years has served China so well. ${ }^{9}$

Aglen's dismissal was, however, not completely unexpected. His defensiveness was previously expressed in his letter to Bowra and it is not surprising that the Central Government simply created a pretext on which to remove Aglen. As IG, Aglen was stubborn despite the pressures that had been placed on him. This was a credit to his integrity and vision for the CMCS, but such rigidity had provided the catalyst for his removal. Furthermore, it is highly unusual that he disregarded advice that he should return north to defend himself. Lampson mentioned that Aglen was very confident that, even if he was dismissed, the native banks at Shanghai would 'clamour for his immediate reinstatement' but this never eventuated. ${ }^{10}$ Misguided confidence had lulled Aglen into a false sense of security. His dismissal was protested by Lampson and echoed by the diplomatic body at Beijing. Lampson recorded: 'I harangued Koo until I had exhausted my vocabulary, I mobilised the Diplomatic Body all to no avail.' ${ }^{11}$ These protests were unsuccessful in reversing the dismissal.

Lampson regarded the dismissal of Aglen as contemptible and embarked on negotiations with the government to secure the future of the CMCS. He recorded Aglen's departure from China with regret saying, '[a] great crowd of foreigners but practically no Chinese at all - the swine. Aglen is a great landmark gone. I wonder if I handled that case strongly enough. ${ }^{12} \mathrm{He}$ was aware, despite his personal disgust at the Chinese treatment of their 'loyal servant', ${ }^{13}$ that foreign interests in the CMCS were the larger issue dominating these events. He explained to Koo, the Minister for Foreign Affairs, the reasons for British interests in the Service: that the Customs provided an efficient machine for the conduct of foreign trade and a security for foreign loans. He also discussed 'the fact that the Service was built up under British auspices which gave us a traditional interest in maintenance [of] its integrity'. ${ }^{14}$ Lampson was perturbed by what he saw as a deliberate action by the Central Government to move the Customs into the sphere of internal politics. Such a perception is curiously naive, however, as the CMCS had since its inception been closely tied to the internal affairs of China. What was now different was the vulnerability of the Service once the foreign powers had shown themselves reluctant to defend it. Consequently the CMCS had to develop new approaches to its close connection with the internal politics of China, and the removal of IG Aglen heralded the desperate need for a new direction for the Service.

\section{7-9 in perspective}

For the British Foreign Office 1928 stood out as a critical year in SinoWestern relations. The year had been especially tumultuous for the 
Customs, in fact, more so than in the whole of the Service's history. Lampson wrote: 'Looking back on the many crises it has passed through during the year, it can only be a matter of surprise that the service has survived the ordeal comparatively unscathed. ${ }^{15}$ The chaos endured by the CMCS was primarily a result of its need to reconcile with the GMD's establishing of its Nanjing regime. The reference to the Service surviving 'comparatively unscathed' is central to this chapter's exploration of the 1927-9 period. Within these years the Service was not only beset with a succession crisis but was simultaneously being drawn into a much closer relationship with the Nanjing Government. The appointment of IG Maze over the Foreign Office-supported Edwardes signified a Nationalist-inspired breaking away from the protection that had hitherto been afforded to the CMCS by Britain and the other treaty powers.

The challenge by Frederick Maze to Aglen's appointed successor, Arthur Edwardes, and the flurry of negotiations that passed between the British Foreign Office, Lampson and the diplomatic body, have been the focus of works on the CMCS. This struggle has been reviewed as endemic of the need for the Service to adapt to Nationalist China. The Customs crisis is presented by Aitchison as a result of the Nanjing Government's revisionism, which threatened the existing unequal relationship between China and the foreign powers. ${ }^{16}$ While also referring to the customs succession struggle as representative of the recognition of the need for adaptation, in contrast Atkin's research tends to dwell more on the personalities and bitterness of this rivalry. ${ }^{17}$ This chapter is a synthesis of these two approaches. In particular the Nanjing Incident of 1927 and its ramifications for the British handling of the challenge to the Customs has received little attention; the succession crisis can be seen as representative of larger forces at play in Sino-Western, or rather GMD-Western relations during the 1928-9 period.

For the treaty powers the nominal success of the GMD in its Northern Expedition was a cause for uneasiness. While the internal chaos of the warlord era had caused consternation among the powers that despaired of China ever unifying, the possibility of a cohesive and strong China was looked on with very real trepidation. There was a reluctant realization that foreign interests in China must undergo some form of change or adaptation to survive in the Nanjing era. As the Nationalists became established, it appeared that internal dissension would no longer allow for the flourishing of foreign trade under the protection of extraterritoriality. A new era was dawning for China and for its relations with the West. The CMCS can, in many instances, be seen as a microcosm of Sino-Western relations. Therefore, the changes that were forced on this service by the GMD provide a reflection of the general experience of the foreign interests in the treaty ports. For the Customs the Northern Expedition was the backdrop to a serious threat to the functioning and fabric of the Service. GMD success plunged the foreign powers into a quandary of recognition or non-recognition and the Customs was also affected. 
The establishment of the Nanjing Government in April 1927 marked a watershed for Sino-Western relations, particularly how this relationship was manifested in the treaty ports. The defeat of Zhang Zuolin's regime in Beijing in June 1928 and his son Zhang Xueliang's allegiance with the GMD in December of that year heralded a unity in China that had not been experienced since 1916. ${ }^{18}$ This realization of a nominally unified China further reinforced the need for Britain and the other foreign powers to recast the relationship they held with the Nationalists. Lampson recorded Zhang Zuolin's demise with much regret as he sensed that political tension would inevitably increase. He reflected:

I certainly regret his failure. I think it might well prove to be a case of 'out of the frying pan and into the fire,' and I have little doubt that when Chang has gone and we find ourselves up against the Nationalists in earnest in our daily routine we shall look back with regret to the peaceful days when Chang was here. Of course I know that Chang was an anachronism and was bound sooner or later to go: he had no real hold on the people and no political insight or knowledge, yet he represents a type which is easier to deal with - I would almost say more honest - than the brand of Chinese with whom we are now confronted. I never knew him not to keep his word, and that is distinctly unusual in China to-day. ${ }^{19}$

Lampson's appraisal of Zhang is insightful as he realized that the warlord had become an anachronism in Nationalist China. He also appeared conscious of the challenges that the Nationalists were going to present to the status quo of foreign interests in China. So too the CMCS as an integral part of the treaty port system and foreign interests in China was confronted with the prospect of change. This challenge came in two predominant forms, the succession crisis and the GMD's move for greater control of the service as evidenced through the quest for tariff autonomy and the sinicization of the CMCS. After breaking Beijing's power the Nationalists possessed the authority to appoint the IG of the Service. The crisis, which had emerged from the Customs succession, was, as Aitchison explains, partly due to Lampson's strenuous opposition to the Nationalists' favoured candidate. It was Lampson's influence that had prevented Maze being appointed..$^{20}$ This, however, is an overly simplistic view of the situation. The agreements under which the Service was first created (as the IMCS) noted that the nomination and recommendation of a candidate to the position of IG was integral to the foreign relationship with the service. Regardless of the political climate of the 1920s, the British retained their sense of 'obligation' to maintain their interests in the Service. While aware of the historical justifications of their claim, the British Foreign Office believed that it would be fruitless and possibly damaging to wider British interests to make demands of the Nationalists. Instead political pressure 
was brought to bear; Lampson's heavy involvement in the succession crisis amply demonstrates that Britain still held considerable interests in the future of the CMCS and still sought to maintain its predominance in this influential institution.

\section{The Nanjing Incident}

British interests in China were faced with ongoing blows to their prestige from 1925 onwards. The Nationalists, moreover, once ensconced in government in Nanjing, sought to ease the singling out of Britain for attack and instead sought to be on better terms with what remained arguably the most influential of the foreign powers. The December Memorandum (18 December 1926) marked a distinct shift in British attitudes towards China and a more conciliatory attitude with regard to the Nationalists. ${ }^{21}$ By the Nationalist era British influence was already a shadow of its preFirst World War strength. The Service, with its close ties to British interests in China, provides a useful vehicle for the chronicling of what has been termed as both British decline and retreat in China. ${ }^{22}$ The CMCS succession crisis and the subsequent failure of the British Foreign Office to assert its will on the Nationalists in winning its approved candidate the IG's post reflects the deterioration of the power once wielded by Britain in Chinese political affairs.

The GMD seizure of Nanjing in March 1927 and the lawlessness that ensued prompted the foreign bombardment of the city. Soldiers ransacked the foreign concessions. Foreigners in the city, both men and women, were attacked, leading to several fatalities. ${ }^{23}$ In response foreign gunboats bombarded the city, providing cover for their fleeing nationals. This could be seen as one of the last distinct acts of gunboat diplomacy in the Republic. As with earlier deployments, the gunboats' bombing of the city caused more long-term ills than good. Subsequent negotiations were strained as the Nationalists demanded apologies for the foreign attack. The sack of Nanjing was evidence of the "public erosion of the status of Britons in China' ${ }^{24}$ The chaos in the city certainly would have added to the British sense of demoralization in China. The attacks against the foreigners in the city further exacerbated foreign fears of the anti-imperialist predilections of the Nationalists. This incident is particularly important to an understanding of the succession crisis, as it influenced all subsequent dealings between the Foreign Office and the GMD.

Shortly after reaching a settlement to the Nanjing Incident, the press in Shanghai enthusiastically seized on a report of an attack on the Customs Commissioner in Nanjing, Johnston. He was assaulted by four Nationalist soldiers. The attack was reportedly unprovoked and particularly vicious in nature, with Johnston being abandoned as dead by the soldiers. The $N C D N$ demanded, 'if soldiers cannot be kept in proper control in the capital, what are they likely to be elsewhere?'. ${ }^{25}$ Johnston's position in the Customs was 
highlighted in the newspaper reports even though this appears to have had little to do with the attack. Both Hewlett's memoirs and British Foreign Office material further confirm that Johnston's position in the CMCS was incidental to the assault. In fact in his memoir Forty Years in China Hewlett suggests that the attack was instigated by Johnston's chauffeur, 'whom he [Johnston] had cursed in public for not obeying a police signal, and had also beaten across the shoulders for driving a little lad on a bicycle into a ditch' ${ }^{26}$ Revenge then was a motive. Hewlett moreover expressed frustration at the way in which his host reacted to the attack. Seeing Johnston's later actions as more inflammatory than constructive, he commented: '[Johnston] refused to give the police any help in their investigations, but added to my difficulties by giving the Shanghai press all the details. ${ }^{27}$ Regardless of whether the CMCS was an issue or not in this assault, the $N C D N$ clearly sought to sensationalize the attack - not only had a Briton been subjected to such outrages but the victim was also a high-ranking Customs employee. It is possible that reporting such as this was designed to encourage some scaremongering among the foreign community in China and to create further indignation over the events in Nanjing.

The physical outrages perpetrated by the Nationalist soldiers and the counter-attack by the foreign powers obscure much of the significance of this event. What is crucial within the framework of this chapter is the mentality with which the British Foreign Office approached the need for reparations. This incident provided further evidence of the 'public erosion' of the position of the British in China. ${ }^{28}$ This served also to increase tensions in the early negotiations between the Foreign Office and the Nationalists. Lampson's correspondence with Austen Chamberlain provides a reflection of the significance with which he viewed the need for a settlement of the Nanjing affair:

Though the results to be expected from a settlement are not easily estimated, a breakdown might be a far more serious matter than is apparent in London. Prejudice will be occasioned to all outstanding questions, Hankow, salt, Shanghai municipal representation, the Customs and so on, while the British subjects and their businesses in Nationalist territory will all suffer. I am also apprehensive of a further volte-face on the part of the Nanking authorities should we rebuff them, and, though one cannot be certain in such matters, Russia is always the alternative to ourselves. ... We are not therefore simply concerned with the Nanking incident, but our whole position vis-a-vis the Nationalists is at issue, perhaps at stake. ${ }^{29}$ [emphasis added]

In the above passage what becomes apparent is the overwhelming apprehension on the part of Lampson that any loss of ground to the GMD would provide the catalyst for the disintegration of all British interests in China. This apprehension can be related to the Service and its succession crisis. 
The further shaking of British confidence that occurred in Nanjing and the subsequent difficulties in reaching an agreement with the Nationalists perceptibly influenced the outlook of the British Minister and the Foreign Office. The Customs succession, therefore, took on a new significance in the wake of the Nanjing Incident. It heightened British concerns for the preservation of 'face' against the Nationalists. Events such as the Nanjing Incident and the CMCS crisis amplified sensitivities to the preservation of the status quo. By 1928 the Foreign Office realized that Britain's relationship with the Nationalists needed more than the recasting directed in the seminal December Memorandum of 1926. It needed a new understanding and a cautious approach.

\section{The succession crisis}

Before the significance of this incident to the future of not only the CMCS but also British interests in the Service can be explored, it is necessary to outline the manoeuvrings that took place, guided most diligently by Sir Miles Lampson, to secure the right man for the coveted position of IG. Lampson was, however, largely frustrated in his attempts to secure the post for the most suitable Edwardes, but not through lack of trying. Rather, it was a gradual easing of Foreign Office support that hampered Lampson as officials had come to see Maze's succession as inevitable. Edwardes' propensity to act without consulting the Minister often had embarrassing consequences. Combined with a shift in power in the GMD government, this meant that the sympathetic Song Ziwen (T.V. Soong) was replaced by a stronger, anti-Edwardes faction, which contributed to Edwardes' resignation from the Service.

Edwardes' claims to the post of IG should have been unrivalled. Aglen had personally selected and groomed him as successor. He was, however, challenged for the leadership by the Commissioner of Shanghai, Frederick Maze. Despite favour from Lampson and the Foreign Office, Edwardes was not successful in assuming leadership of the Customs. Aitchison represents the difficulties in Edwardes' rise to leadership as stemming from the success of the GMD in their Northern Expedition. This interpretation of the main obstacle is rather too simplistic. It is possible, although slightly controversial in light of the other works on this incident, to contend that Edwardes' failure was a fait accompli even at his naming as successor. When Aglen had been dismissed and had appointed Edwardes as his hand-selected replacement (undoubtedly a successor in whom he could be confident that his vision for the CMCS would be maintained), this was already a portent of disaster.

After Aglen's dismissal Edwardes was appointed as the Officiating IG. Aglen handed over charge of the CMCS but retained his title and remained as IG on the Service List for a further year. ${ }^{30}$ In doing so, the need to definitely secure a replacement for the top post was effectively held in 
abeyance. This arrangement was achieved through the offices of Lampson, who also ensured that he got 'Aglen the G.C.M.G., which had some moral effect' ${ }^{31}$ Aglen's dismissal had marked the end of an era for the Customs, one that had been considered quite difficult, but the CMCS would be confronted with many more serious challenges in the succession struggle and the years to come. By March 1927, Lampson had come to believe that the position of foreigners in China's service was endangered, with both events in the Customs and threats to the postal service further confirming this. He reflected:

What a splendid country we live in to be sure. All foreign employees are clearly to be driven out: that is the programme of both North and South, though the former set about it in a more regular and less revolutionary way. ${ }^{32}$

With such a sense of foreboding, it is not surprising that in the struggle for the appointment of IG (predominantly played out between Lampson and the Nanjing Government) Lampson seized on the challenge with such vigour. For Lampson, the decline of British influence in the Service needed to be stemmed before it destroyed the foreign inspectorate.

Aglen departed for London in March 1927 and does not appear to have severed all links with the Service. Although Edwardes may have not known it, the possibility of Aglen's returning to the post of IG was still given some credence. Lampson intimated in a letter to Clementi that the deal to allow Aglen to be listed as IG served to cover any eventualities. He wrote: 'If this arrangement goes through there is just a possibility, should there be a change of government here, that Aglen may be fully reinstated. In any case, the door is at least kept open. ${ }^{33}$ No doubt the success of the GMD in establishing their Nanjing Government would have made it clear to Lampson that any hope of Aglen returning had become impossibility. The later GMD success in June 1928 in forcing Zhang Zuolin to flee Beijing would have further confirmed the permanency of Aglen's removal from the Service.

During June and July 1927 the possibility of a divided Service came to the fore. Lampson, when recounting this to Chamberlain, refers to Maze (without specifically naming him, but the inference is clear) and the efforts being made to divide the Service. He commented that such moves had 'received some encouragement from interested individuals in the Customs Service at Shanghai'. ${ }^{34}$ To counteract this Lampson made personal representations to the Nanjing Government, which responded favourably, inviting Edwardes to travel to Shanghai for discussions. Zhang Zuolin, who had recently established a military dictatorship in Beijing, prevented Edwardes from doing so. Despite the need for such representations, Lampson saw that the situation involving the CMCS would remain unchanged until the uncertainties existing in the political climate were 
brought to some resolution. Later in the same dispatch he mentioned the IG issue and the overarching concern of Nationalists' claims of control of Inspectorate as being 'for the moment dormant'. ${ }^{35}$

\section{Edwardes and Maze: The rival candidates}

Before delving deeper into the actual events surrounding the struggle for the position of IG of Customs, it is timely to briefly introduce both candidates for the position.

Edwardes was the Foreign Office-endorsed candidate and was strongly supported by Lampson in particular. Edwardes was Aglen's appointed successor and therefore was considered acceptable by the British and other foreign establishments. ${ }^{36}$ As Edwardes was seen to follow Aglen's lead, as regards the CMCS relations with the Nationalists, his candidature even at the outset promised difficulties with the Nanjing Government. He had developed a good relationship and even friendship with Lampson, most probably spurred on by their common experience of being new to their posts in Beijing ${ }^{37}$ and also through their contact in the lead up to Aglen's dismissal. ${ }^{38}$ This rapport is most visible in the numerous social meetings with Edwardes, which are noted throughout The Killearn Diaries. ${ }^{39}$ Through Lampson's recommendation the Foreign Office viewed Edwardes as the 'right man' for what was potentially a difficult job. ${ }^{40}$ Importantly he inspired confidence that British interests would be taken into consideration. Edwardes perceived the role of IG as one that involved a close liaison with the British Foreign Office. This is evidenced most clearly through his close contact with Lampson and the extent to which he relied on the Minister's support. ${ }^{41}$ Edwardes also enjoyed the support of the Japanese. The Japanese maintained their own agenda of ambitions for greater presence in the Service but were supportive of Edwardes' candidature..$^{42}$

Edwardes, while being firmly supported by the foreign communities in China and by the foreign powers, lacked any substantial Chinese support. Apart from a consortium of Chinese bankers who approved of his tariff plans, he was seen as merely a second Aglen (who, it must be remembered had not established a good relationship with the GMD). Edwardes, moreover, was recognized as having been demonstrably anti-GMD in his own right. According to Maze a constant objection raised by the Nationalists against him was that he was not seen as acting in the Chinese interests. ${ }^{43}$ This was evidenced by the Nationalists when, during his Commissionership at Guangzhou and in response to the Shamian incident, he had shut the Customs offices despite instructions not to, and it was even claimed he had been shot as a result of his being in the volunteer corps of Shamian. ${ }^{44}$ The objections were not only personal: "the main feature of the situation is the determination of the Nationalists not to recognize Edwardes' appointment in any shape or form' ${ }^{45}$ In this way, the objections 
to Edwardes were presented as part of the Nationalists' desire to completely distance themselves from the excesses of Beijing (both under the Qing dynasty and the warlord regimes).

As the challenger to the post, Maze did not find much support in British or foreign circles, but appears to have enjoyed support from elements of the Nationalists. He had not been nominated as Aglen's successor, for although senior to Edwardes in length of CMCS employment, he was considered too close to retirement age. A nephew to the legendary Hart, Maze's claims to the IG's position were compelling in terms of experience and proven administrative skills. His candidature does not, however, appear to have been considered by Aglen when selecting a successor. ${ }^{46}$ Maze's appointment as Commissioner at Shanghai had left him with little choice but to work closely with the Nationalists, and in doing so he had shown himself to be a capable administrator who never failed to appreciate the longer-term picture of the Service. Maze was supported by neither the Foreign Office nor Lampson, who saw him as scheming, disloyal and frankly un-British, typified through his preparedness to allow himself to be used by the Nationalists. Atkins provides an interesting suggestion as to why Maze was such a maligned character throughout the succession crisis and even after. He discusses that an underlying assumption had been drawn in regard to Maze, that to collude with Chinese interests meant an inherent corruption of one's morals. Futhermore, he comments that Maze had directly challenged one of the tenets of the 'psychology of informal empire in China: that Western logic and morality alone could decide the right course for China to take' ${ }^{47}$ Maze certainly appeared to run against the grain of the predominant psyche of foreign communities in China at that time. Even though Maze was maligned for dragging the Service into politics, the CMCS had always been an inordinately political organ through which the foreign powers could exert influence, but the link had not, until the rise of the Nationalists, surfaced so publicly and in a manner considered so threatening to British interests.

As late as January 1928, Aglen was still toying with the idea of returning to China. Edwardes intimated to Lampson that Aglen was considering a return to China, ostensibly to settle private affairs. Edwardes admitted to Lampson that he had discouraged such an action. Lampson fully supported his dismissive attitude towards Aglen. ${ }^{48}$ Certainly Edwardes had reason to be concerned that Aglen's return may affect the present status quo in the CMCS.

When Aglen's leave expired on 9 February 1928, the position of IG was formally vacated. The tensions and conflicts between the rival candidates and their supporters emerged. The struggle had begun in earnest. Lampson reported to the Foreign Office that Maze was known to be scheming with the south for appointment as their IG. He feared that this would precipitate the Service being torn asunder. Lampson commented: 
This would destroy the unity of the Customs Administration and be the cause of extreme embarrassment to us, and a development of this kind is most undesirable from every standpoint. Mr Edwardes was chosen and trained by Sir F. Aglen as his successor. He is in the right place as Inspector-General and has justified his appointment during the last twelve months. ... I shall afford Mr Edwardes full support if an issue is to be faced. ${ }^{49}$

The reference of Edwardes being in the 'right place' to be IG is a curious one. Undoubtedly Edwardes was appointed as Aglen's successor but his former chief was not endeared to the GMD and Edwardes was regarded as the same by the Nanjing Government. As for physical location Edwardes remained in Beijing, the traditional headquarters of the CMCS, although it was readily apparent that, as the Nationalists dominated the government, there was possibly a justification for relocating to Nanjing. By saying that Edwardes was in the 'right place' to be IG, Lampson must surely have referred to his being groomed for the position, of doing things the 'right way'.

While supporting Edwardes' claims to be IG, Lampson found willing supporters in the Japanese. On several occasions he discussed the possibility of enlisting the Japanese Minister, Yoshizawa, to bring political pressure to bear. ${ }^{50}$ With Lampson's encouragement the British and Japanese consuls in Shanghai let their support for Edwardes be known and asserted that any intended splits in the Service 'would not be tolerated'.${ }^{51}$ Japanese support, however, did not come unconditionally. In January 1928, Edwardes was perturbed at Japanese intimations that, in return for their support, the Chief Secretary in Beijing, Kishimoto, would next succeed when Edwardes retired. Lampson's reaction, after giving Edwardes permission to dispel any such 'dangerous illusions' was to further emphasize his own belief that the IG would always remain British. ${ }^{52} \mathrm{He}$ commented that '[the Customs] has been built up on purely British lines, its whole tradition and character are British, and under any but British leadership it would go to pieces'. ${ }^{53}$ Lampson was prepared to encourage Kishimoto being definitely confirmed as Chief Secretary on Edwardes' appointment but, despite this overture, clearly did not entertain ideas of further aiding Japanese ambitions for the Service.

For Lampson the succession crisis held a deeper significance, broadly representing all British interests in Nationalist China. He believed it was essentially an issue not as to who was appointed but rather whether a 'halffledged' Chinese Government would be able to dismiss Edwardes for purely personal reasons and to give preference to Maze. He saw Edwardes' departure as representing a bad omen for anybody who tried to stand firm in a foreign-controlled administration. In a message warning Chamberlain of what he recognized as imminent danger to British interests, Lampson wrote: 'If Mr Maze is successfully appointed, the Nationalist Government 
will feel, and will rightly feel, that they have taken our measure and that we no longer count. In short, our whole position and influence will have been undermined. ${ }^{54}$ In this warning he also urged that more consistency in the FO's backing of Edwardes was essential. Clearly he saw the outcome of this crisis in a similar light to that of the Nanjing Incident - that failure to assert British interests at yet anther critical juncture would have a flowon effect, allowing a deterioration of the already weakened hand Britain enjoyed in Anglo-Sino relations. The Foreign Office paradoxically was, as time passed, not so inclined to see the situation in the same urgent light as Lampson. While the Foreign Office had gradually lost some conviction that Edwardes was indeed the most suitable candidate, the prospect of Maze's appointment was not looked on with any renewed enthusiasm. Pragmatism dominated the Foreign Office's assessment of the situation, and the attitude adopted was that should Maze be appointed despite strong British urging against it, then all concerned should 'try to make the best of it'. ${ }^{55}$ This pragmatism contributed to Lampson's growing frustration over events surrounding the succession. ${ }^{56}$ Such a lukewarm response by the Foreign Office led him to feel that his pressure alone was keeping Edwardes as Officiating IG. To his chagrin this fact was something that he felt he needed to remind even Edwardes. ${ }^{57}$

Throughout the gathering storm surrounding the Customs, Maze was constantly referred to in terms of whether or not he was doing the right thing and of doing the 'British thing'. In early February 1928, as a response to Edwardes and Lampson's fears that the service was to be divided, Lampson authorized Sir Sidney Barton to approach Maze on his behalf. This was an appeal to Maze to withdraw his candidature and therefore relieve what had become, for the British interests, a complicated and potentially embarrassing situation. Maze was exhorted by Barton to be a 'loyal British subject' and to consider his devotion to the CMCS. ${ }^{58}$ Apart from protesting that the matter was really a concern between north and south and not the foreign powers, Maze assured Barton that the outcome would not greatly affect the CMCS interests. The most damning part of this reported meeting, however, came when Maze repeatedly told Barton:

he [Maze] would be prepared to resign and to leave the field clear if it were made worth his while to do so by the grant of a higher pension and the bestowal of a decoration from His Majesty's Government. ${ }^{59}$

This reply prompted Edwardes to announce his intention to resign rather than to play any part in the consideration of Maze's 'blackmailing tactics' ${ }^{60}$ As can be imagined, the response to such avaricious demands ranged from the righteous indignation of Edwardes, who would rather resign than see Maze 'bought off' in such a way, to Foreign Office references to Maze as a man who 'had his price'. This incident was significant in blackening Maze's reputation and further confirmed Lampson's conviction that he 


\section{2}

was simply not the right person to be IG. The accuracy of Maze's comments is unclear; a passing remark could easily have been seized upon, out of context, to discredit the less-favoured candidate, but conversely Maze would not have been the first to seek compensation for laying aside his claims. This may indeed have been the case, but Maze subsequently argued he was misrepresented. ${ }^{61}$ Lampson was among many at the Foreign Office who seized on Maze's comments to Barton as further evidence of his unsuitability for IG.

In a bid to create a rapport with the Nationalists, Edwardes journeyed to Shanghai in mid-1928. Negotiations were arduous, with Edwardes being forced to bluff Song and his government into action - threatening to leave Shanghai and not return for further discussions until the Nationalists recognized him as head of the CMCS. ${ }^{62}$ Edwardes' appointment and recognition as Officiating IG by Nanjing in October 1928 was a hard-earned concession, the basis of which had at times appeared quite shaky. The $N C D N$ devoted an editorial to 'The Customs', the tone of which was jubilant when Edwardes had been chosen as chief of the Service. In the editorial the $N C D N$ declared that the widespread concern over the deterioration of the Service could cease as Edwardes would serve with 'loyalty, resolution and honesty of purpose' ${ }^{63}$ This appointment, paradoxically, was a hollow victory for Edwardes. Conditions had been attached to his recognition that essentially rendered his position no longer tenable; Edwardes had agreed that the Ministry of Finance alone could appoint Commissioners, albeit with his recommendation. More importantly his hands were tied as regards his rival, Maze.

While Edwardes' appointment as Officiating IG appeared to have equipped him with necessary authority over the Service, the position was a superficial one. Thus he did not have the authority necessary to once and for all eliminate his rival, Maze. Moreover, as a condition of his appointment, Edwardes was specifically prevented from taking retaliatory action and punishing Maze. ${ }^{64}$ As a further blow to Lampson and Edwardes' efforts, Maze was appointed the substantive post of Deputy IG. This was interpreted by the $N C D N$ as an obvious compromise; 65 it fuelled press speculation that Edwardes might indeed resign his post. Lampson, who was predictably perturbed by events, suggested a solution that Maze could be sent home on leave. ${ }^{66}$ Edwardes supported this idea and without further consultation with Lampson acted on this.

Edwardes tested the extent of his power as Officiating IG by attempting to remove Maze. In what can only be considered an ill-judged action, he sent a telegram to Song, which, if agreed to, would have removed Maze from the Service. According to Lampson's diary entries, this move was precipitated by Shanghai Chinese bankers' expressions of outrage on Edwardes behalf, imploring him to return to Shanghai to defend himself. ${ }^{67}$ Edwardes, no doubt buoyed by such promises of support, wasted little time in telegraphing Song and enquiring: 
Will I, in capacity of Officiating Inspector-General of Customs, have your authority to instruct Mr. Maze to proceed on a year's leave immediately with the rank of Deputy Inspector-General of Customs, with retirement at the end of such leave? ${ }^{68}$

By sending this telegram Edwardes forced Nanjing to define the boundaries of his power as Officiating IG. This action marked the climax of the succession struggle that had been waged for the past year.

The British Foreign Office response to this telegram was one of strategic distancing; the pending question of tariffs was considered too important to be jeopardized or eclipsed by the rash actions of Edwardes in the struggle for leadership of the CMCS ${ }^{69}$ For Lampson, Edwardes had not only dealt him a blow through sending the telegram but had also failed to consult him beforehand. He maintained that Edwardes had not only behaved badly but had committed a blunder that Lampson feared he was unable to rectify. ${ }^{70}$ The lack of discernment on Edwardes' part cast a poor reflection on Lampson as he had invested so much in nurturing this candidate.

In accepting his posting as Officiating IG, Edwardes was confronted with the issue of removing the Inspectorate to Nanjing. Displaying his dependency on Lampson, Edwardes referred this to his attention. The NCDN reported Edwardes as 'taking the Powers' opinions on the question', and as the powers were not favourably inclined, Edwardes proposed to remain in Beijing. ${ }^{71}$ For the foreign communities such inaction on Edwardes' part would have been a reassuring sign that he would not simply acquiesce to the Nationalists' demands. For the Chinese this would have further strengthened their objections to him. In the Customs circulars Edwardes informed the Service that, as no suitable space could be found at Nanjing, the Inspectorate would open a temporary headquarters in Shanghai. ${ }^{72}$ This exacerbated the already existing rivalry with Maze and led Edwardes to protest over the dual administration that he believed was occurring.

The GMD's bid for revision of the pre-existing tariff system drew the Foreign Office's attention away from the Customs struggle. The Sino-US Agreement (26 July 1928) afforded China tariff autonomy on 1 January 1929 , conditional on 'most favoured nation' treatment and the consent of the other powers. In his study of British policy in China at this time, historian Fung asserts that this action, while not conceding much to the Chinese, implied de jure recognition of the Nationalists and their Government. This therefore accelerated negotiations with Britain with the result that the Anglo-Chinese Tariff Agreement was signed on 20 December. According to Fung this had twofold significance. It cleared the way for better GMD and Foreign Office interaction and also eased the way for filling the IG's position. ${ }^{73}$ In this contention Fung raises a significant factor that had served as a foil throughout the succession crisis: the GMD's desire to establish better terms with the British. Under this light Lampson's pressure to keep Edwardes in place was so successful because treaty revision was a leverage 
that could be used. Furthermore, it was not long after the Anglo-Chinese Agreement that the succession crisis reached its climax and Edwardes submitted his resignation. In following this line of argument, Edwardes' initial successes were reliant on the desire of the Nationalists to see a review of the offending 'unequal treaties'. Moreover, his demise, despite Lampson's continued efforts, was due in part to the British Foreign Office's reluctance to jeopardize these negotiations.

Edwardes' resignation on 31 December 1928 was the culmination of an increasingly bitter impasse, which had held the Customs in its grip. The $N C D N$ presented Edwardes as a victim of scheming Chinese factions that had deliberately sought to transform the Service into a political entity and, in doing so, secure their own financial interests. The partisanship of the $N C D N$ was apparent throughout the succession crisis. An editorial commented, 'reflection does nothing to dispel the ugly impression caused by Mr Edwardes' resignation', effectively setting the tone for an article lamenting the downfall of a man of integrity. ${ }^{74}$ The appointment of a successor was written of in sketchy terms but a clear warning was held for Maze. The article stated that a new IG should not have his powers diminished in any way and that he should have 'the ability to enforce discipline, if he cannot count on loyalty'. ${ }^{75}$ It was with veiled barbs such as this that Maze faced his appointment as IG of the CMCS. While the succession crisis may have ended, it left a bitter taste for many that would cause tensions lasting well into Maze's leadership.

From the outset many readers of this incident may seek to write it off as mere rivalry within the CMCS institution and in doing so fail to recognize the significance of this crisis to the Customs. The struggle that ensued over the appointment of the new IG affected the Service's relationship with both the GMD and the West. Researchers may be tempted to ask: was there a crisis? Wouldn't the appointment of a Chinese to the IG's position have been a 'real' crisis for the Service? These questions are somewhat misleading as, while the appointment of a Chinese to the leadership of the Service would indeed have caused a crisis, neither the northern militarists nor the GMD leadership were prepared to antagonize the foreign powers by doing so. The Service was a lucrative source of income for the Nanjing Government and such upheaval might have marked the collapse of the Service and, therefore, of Chinese financial security. Had the northern leaders and the GMD leaders attempted to move control of the Customs into Chinese hands, there was a great possibility of disrupting this revenue source and antagonizing the foreign powers at the same time. The crisis that emerged after Aglen's dismissal did not stem from the Chinese attempting to take control of the CMCS but rather from their support of a candidate who had not received foreign (and therefore 'official' sanction). The GMD's support for Maze against the foreign-selected Edwardes is evidence that the Nationalist leaders were attempting to assert more control. Maze had not been nominated by the British Minister and was considered 
too pro-GMD for the liking of the diplomatic body and yet had enough backing to displace Aglen's successor, Edwardes. The bitterness of this struggle and the resultant ostracizing of Maze by Shanghai's foreign community further highlighted the importance of this succession to foreign interests in China, or at least to the perceived interests the foreign powers held.

Although he expressed uncertainty with regard to the suitability of Edwardes, Lampson decided to support Aglen's nominated successor to the best of his ability. On several occasions when Edwardes' injudicious actions threatened to undo all good work done on his behalf, Lampson reflected that maybe he had not supported the most suitable candidate. He commented, 'throughout this business I confess I have never been entirely at ease in my own mind that Edwardes is entirely the right man for the job' ${ }^{76}$ The main reason why Lampson was prepared to apply pressure as necessary to support Edwardes was that of the whole thing being a matter of principle. Aglen had nominated Edwardes to the post and, regardless of the changing forces in the political climate, Edwardes was justified in his claim to become IG. For Lampson there were personal considerations at stake. Maze had shown himself as a "man who has his price'"77 and therefore Edwardes, who knew how to play the game, was a much more suitable contender for the post. For Lampson there was also the principle of standing up for his beliefs - he had pledged his support to Edwardes but was repeatedly frustrated by his increasing pessimism and also the Foreign Office's distancing itself from the situation. As Lampson wrote: 'I have been placed in a thoroughly ridiculous and degrading position.' Not only did Edwardes' failure to hold a substantive appointment reflect on Lampson's authority in China, it also threatened the severing of the ties between the British Foreign Office and the Inspectorate, ties which Edwardes' relationship with Lampson had exemplified. While the succession crisis may at the outset have appeared as a proverbial storm in a teacup, its ramifications were extensive and it marked the Foreign Office's conscious distancing from the Service.

\section{An IG scorned: Frederick Maze}

I would like to emphasise that if Mr Edwardes goes it will be quite impossible for me to work with Mr Maze. I regard him as thoroughly dishonest and dishonourable and as having at the time of greatest need sacrificed [the] customs service to secure his own private interest.

Miles Lampson ${ }^{79}$

Edwardes' resignation cleared the way for Maze. The tensions that had surfaced between Maze and the British establishment in China during the succession crisis threatened to continue. In doing so they created a definite breach between the new leader of the CMCS and British interests in the 
service. For Maze, his success in becoming IG had been earned at a price. His ambition, coupled with the GMD's determination, left him a social pariah in Shanghai. Maze was further marred by a campaign carried on by the treaty port press. This campaign maligned him subtly (and sometimes none too subtly), associating him with opportunistic and downright anti-British behaviour. The early years of Maze's leadership saw unprecedented change in the Service, the benefits of such in prolonging the fate of the institution, only grudgingly acknowledged by the British.

Maze was fully aware of the opposition or, at the least, resentment he faced when first assuming office. By the time of Edwardes' resignation, many (including Lampson) had begun to question the suitability of one so readily inclined to abandon his candidature and lacking in discretion. ${ }^{80}$ Despite this Maze was not accepted as even a possible alternative, his machinations earning him British disgust. When a desperate search for a third candidate proved too late, it was accepted with regret that Maze should take the post unopposed. He was aware of the reluctance of the British Foreign Office to support what they saw as a further loss of their prestige in Chinese affairs. Maze, through Non-Resident Secretary (NRS) Stephenson, sent a message to Chamberlain demanding British support for his position. He deliberately circumvented communications with the Ministry in Beijing, no doubt conscious of his poor relationship with Lampson over the succession. By going straight over the Minister's head, Maze placed him in the embarrassing position of simply having to find out what was happening through sources at home. Maze telegraphed Chamberlain:

Post of Inspector General is now one of unprecedented difficulty, and if British Legation persists in antagonistic and unsympathetic attitude, this difficulty will be needlessly accentuated and position jeopardised. Furthermore, a dangerous atmosphere of uncertainty and distrust inimical to British financial interests secured on the customs may be engendered unless I receive reasonable support from British Government. - (Signed) MAZE ${ }^{81}$

Chamberlain gave this demand a cold reception, as he in fact sympathized with the difficult position Lampson faced. Nevertheless Chamberlain instructed Lampson to accord Maze the support and courtesies due to his position in the interests of good relations with the Chinese and, more importantly, for the survival of the Service. Clearly, the preceding months had engendered much bitterness. It is noteworthy that Chamberlain wrote of supporting Maze as giving him 'his official countenance'; $; 2$ both the Foreign Office and Lampson were forced to make the best of what they considered a bad situation.

Throughout the Customs succession, the issue of the partisanship of the candidates to either British or GMD interests was continually raised. Unsurprisingly the loyalty, or rather protectionist tendencies, towards the 
British and other foreign interests in China displayed by Edwardes were much better regarded than the manipulative and pro-GMD tendencies of Maze. Both during and after the struggle for the IG's post, the Western press in Shanghai and beyond China often drew and redrew the connections between Maze and the GMD. In an article by The Times that announced the appointment of Maze to IG, mention was made of his early relationship with Sun Yatsen. The article from the paper's Shanghai correspondent reads:

On the occasion of Sun Yat-sen's triumphant return to Canton after the revolution had been effected its leader was entertained at a garden party given by Mr Maze at the residence of the Commissioner of Customs, which stands at the far end of Shameen. ${ }^{83}$

A link with the Nationalists' revered leader, Sun, appears to have little to do with Maze's appointment to IG of the CMCS and yet, the correspondent felt it was noteworthy. Such detail may appear rather trivial but it is conceivable that this was deliberately included as a further reflection of Maze having long-held nationalist sympathies.

The ceremony that marked Maze's appointment to office attracted further criticism. As part of this official event Maze took an oath of office in which he committed to serve the Chinese people but also declared loyalty to the GMD and the Nanjing Government. ${ }^{84}$ The $N C D N$ wrote of this as a 'humiliating' and more significantly 'demeaning' oath, and declared that it ran directly counter to his 'duty as a British subject'. ${ }^{85}$ The main objection, the press felt, was not in Maze having made such an oath, but that he had specifically sworn his obedience to the GMD. The article continued:

the pointed dragging in of the Kuomintang as the special object of allegiance and arbiter of punishment, which is but one party in the state, and, for all anybody can say, may have blown to pieces a year hence, leaves a very unpleasant taste, intensifying the fear that the Customs service has become a mere political plaything. ${ }^{86}$

Maze's actions were interpreted as a confirmation of his pro-Chinese tendencies. Furthermore Maze had made it clear through this oath that his loyalties rested with the GMD. The Foreign Office also noted Maze's oath but Lampson made no discussion of it. ${ }^{87}$

Maze's appointment had not only political but also social repercussions. Following his appointment, Shanghai's foreign community shunned Maze and his wife. Lampson referred to the manner in which the foreign community ostracized the Mazes, and in one instance appears to have tacitly encouraged it. When visited in November 1929 by Malcolm MacDonald, the son of the British Prime Minister, and learning that he had been invited to stay with Maze, Lampson duly advised him against 
this. He gave MacDonald a description of the feeling against Maze that still existed in Shanghai. Lampson revealed his bitterness, writing:

I was careful to point out that I did not wish him [MacDonald] to think that I had any bias against Maze personally. The Maze-Edwardes question had been most unpleasant; but that was past and done with, I hoped. But unfortunately the Shanghai community had taken it very much to heart, and had more or less banned Maze. For myself, I thought that it was unfortunate; for, after all, Maze was the head of a great institution backed by British tradition; and although people might not wish to take Maze to their bosom and might have their own personal views about the whole question, nonetheless I thought they were wrong to ban him openly. ${ }^{88}$

Lampson helped to arrange other accommodation for MacDonald with McNaughton, the Vice Chairman of the Municipal Council. He saw that this host would be 'as good a person as anyone to keep him [MacDonald] on the right rails' ${ }^{89}$ Lampson had ensured that Maze's offer was declined and had made it clear that his own feelings were in accordance with the Shanghai community's. Maze was aware of Lampson's disdain and described himself as having been 'systematically ignored' by Lampson and the Consul General. In light of these experiences he attributed the difficulties of meeting with MacDonald privately as being a result Lampson's machinations. ${ }^{90}$

\section{The Maze administration's first year}

The rhetoric with which Maze was ushered into office was one of the need for change. To Lampson and the Foreign Office, this was interpreted as an inevitable decline of the Service. In a responding speech to the Master of Ceremonies at his appointment to office, Maze spoke of the need for the Customs to change in accordance with the times. These comments were criticized by the $N C D N$, which declared that Maze was wrong in his assertions. An editorial on 'The Customs' demanded that the Service should remain 'solid and inviolable, proof against capricious manipulations of the irresponsible and self-seeking'. ${ }^{91}$ Despite such portents of doom for the Service, the early years of Maze's administration successfully brought the institution into a better understanding with the GMD and, in doing so, ensured its survival. This survival, however, was earned at the price of weakening British contacts with the Inspectorate.

The maintenance of the IG's headquarters in Shanghai and the later establishment of a headquarters in Nanjing on 1 February 1929 was a significant gesture to GMD interests on Maze's part. ${ }^{92}$ This move not only allowed Maze to assert his leadership over the Service, but it was a means of demonstrating good faith to the Nanjing Government. It also coincided 
with the declaration of tariff autonomy. Maze's move was a symbolic shift away from the traditional CMCS base of Beijing into a new setting; a reflection of his desire for the service to echo the GMD's move away from the past centre of administration and power. The real basis of Customs administration however, remained in Shanghai. The new head office was intended to act as a liaison office between the Inspectorate in Shanghai and the Nationalist Government until it was possible to combine the two. ${ }^{93}$ While Nanjing may have been named the head office, correspondence was directed to Shanghai. ${ }^{94}$

In Shanghai the local GMD headquarters chose to celebrate the declaration of Customs autonomy. On 1 February 1929 a celebratory meeting would be held. Furthermore the Nanjing Government would be petitioned to declare the day 'Customs Autonomy Day' ${ }^{95}$ The $N C D N$ presented the new tariff agreement as undeniable proof of the sincerity of the Western powers' dealings with the Nationalists. In an editorial entitled 'The New Tariff' the breakthrough for China was presented as evidence of the foreign powers' friendly desire to accommodate Chinese wishes. ${ }^{96}$ Despite this confidence in the new agreement, the article foretells potential difficulties the tariffs may cause to the Customs as the new system of classification was regarded as too complicated.

The sinicization of the CMCS was a delicate issue that had long played on the prejudices and fears of foreign interests in this institution. In April 1929 this issue surfaced again. Maze agreed with Chinese desires to see greater opportunities for their nationals within the Service on the whole. He explained to the Foreign Office (via the NRS in London) that he had long recommended that Chinese be given access to posts of greater responsibility and that this principle had received official recognition. In fact he claimed that, as early as April 1928, the Nanjing Government had contacted him about the status of Chinese employees. ${ }^{97}$ He was quick to reassure the Foreign Office though, that despite these moves, the Government to his knowledge had no intention of removing all foreigners from the Service.

To further emphasize that the foreign element of the CMCS was not under threat, Maze removed previous blocks on employing foreign staff. From 24 February 1927 Edwardes had suspended the further recruitment of foreigners. This was largely in response to the anxiety following Aglen's dismissal and concern that the Service should confine its expenditure. Edwardes reasoned that not appointing any foreigners was a precautionary measure and would remain in place until the uncertainty surrounding the Service was brought to a resolution..$^{98}$ As evidence of his rapport with the GMD and his negotiation skills, Maze had this restriction lifted and foreign tidewaiters were employed. In a circular sent to all ports Maze sought to dispel concerns over the direction of the Service. ${ }^{99}$ In doing so the improving status of Chinese employees was referred to in terms of being both a 'natural and national development' for the Customs Service. 
As a further part of this sinicization of the Service, Chinese employees were also given study scholarship opportunities. ${ }^{100}$ These competitive scholarships, offered biannually, were designed to give successful candidates an opportunity to study international customs systems firsthand. The feared expulsion of foreigners from the CMCS did not eventuate but the balance of Sino-Western relations inside the Service began to change.

Despite the understandably pessimistic view of Maze's leadership taken by Lampson, even he was forced to admit the imagined disasters facing the Service had never materialized. As Aitchison elucidates, Maze's critics and the press seized on his appointment with the assumption that he would head a deteriorating institution; ${ }^{101}$ the deft abilities of Maze, however, did not allow such an eventuality. The Maze administration's first year had proved its harshest critics wrong. The Service did not collapse but rather enjoyed an unprecedented relationship with the GMD that would not have been imagined possible under Aglen or Edwardes. This success in directing the CMCS in its relationship with the GMD was regarded with both relief and, in some instances, grudging admiration. Lampson reflected:

there is a general feeling of relief, both inside and outside the Service, at the restoration of its internal harmony and the comparative smoothness with which the new regime is operating, as well as a general recognition of the ability, tact and success with which Mr Maze has directed the affairs of the Customs administration. ${ }^{102}$

Such commendations were echoed in Foreign Office reports. Moreover Lampson admitted that the Service was in a better state than one could have 'dared to hope' even a year previous. ${ }^{103}$ For Maze this respect for his leadership was a hard-won concession but tensions still remained. Concessions to GMD interests may have indeed been necessary in the changing political climate but Maze's behaviour had caused a rift between the IG and the British establishment in China. 


\title{
5 Charting a new course \\ The proposed Hong Kong-China Trade and Customs Agreement, 1929-30
}

\begin{abstract}
It must be considered that we now live and have our being in post-Revolution, post-War and post-'30th May' days; but Aglen put the telescope to his blind eye, failed to read the writing on the wall, or, having read, to interpret correctly its stupendous import. The gathering storm - hurricane, I ought to say - was ahead and he should have altered his course and stood for safer seas. But, no, he held stubbornly on, lost some of his sticks, and it fell to me, at the eleventh hour, to assume command and put the ship about in order to avoid total loss.
\end{abstract}

Frederick Maze ${ }^{1}$

Maze's leadership of the Customs Service was tempered with pragmatism. During the succession crisis and its aftermath, he had no illusions that he was indispensable. Rather he continually sought to reaffirm the usefulness of the CMCS and its foreign inspectorate to Nationalist China. In many letters during 1930 Maze constantly drew on maritime analogies to describe how he perceived his role as Inspector General (IG) and the future for the foreign staff of the CMCS. The reviving of negotiations with Hong Kong authorities in 1930 surrounding a proposed agreement over the rights of the Customs to operate within the colony's waters was a significant event in the early years of Maze's administration. This chapter examines the significance of these negotiations, not just between Hong Kong and the Nationalists but also for Maze's leadership of the Service. For Maze the negotiations would serve several purposes: to secure and strengthen his position at the helm of the CMCS; to steer the Service towards safer, calmer waters; and, in doing so, to increase the usefulness of the CMCS to the Nationalists. Maze's involvement in these negotiations signalled a new era for the Service as he had moved away from the semi-independent stance adhered to by Aglen and instead actively pursued GMD interests. The negotiations between the Hong Kong authorities and the CMCS, on behalf of the Nationalists, however, were soon swamped by the rhetoric of selfinterest from both parties and the agreement never developed beyond proposals and counter proposals. The Nationalists would gain access to the 
colony's waters and, therefore, revenue that had been previously lost. For Hong Kong's authorities, the proposed agreement caused a questioning of the colony's legal status. The agreement would give Hong Kong the benefits of being a treaty port but would simultaneously infringe on its autonomy from Mainland China. Clearly both parties wanted the proposals to be determined in their favour.

Significant challenges mark Maze's first years of leadership as particularly crucial in determining the future direction and, indeed, existence of the CMCS. In the discussion of the proposed Hong Kong Agreement, Maze was attempting to find some reconciliation to their often-strained relationship with Hong Kong concerning smuggling in particular. The freedom of Hong Kong waters had allowed piracy and smuggling to flourish, a bane for the CMCS, which prided itself on regulating foreign trade with China. The negotiations with Hong Kong, however, raised suspicions on either side, as the British, fearing a subtle attack against their hold on the colony and the New Territories, were not prepared to make any concessions without corresponding allowances for British trade on the inland river systems of China. The Customs Service and GMD in turn did not want to weaken their own positions by setting dangerous precedents for British traders' penetration beyond the scope of Customs-monitored areas. While negotiations travelled back and forth, between the colonial authorities and Maze, China lobby and business groups, both within and outside China, saw fit to lend their voices to an increasingly confused debate.

This chapter highlights the ambivalence of the CMCS in its relations in China and more so with Hong Kong. The Service was synonymous with foreign interference in Chinese affairs. Yet when it entered into negotiations with the Hong Kong authorities regarding the patrolling of the waters, the Service was perceived as a threat to the British colony. The idea of the Customs as a potential threat to British interests in the East in general appears to have gained some currency as even Lampson reflected on the CMCS as being used to reclaim the New Territories. In this sense the Service was a force that offered China a chance to consolidate its interests.

\section{An 'irreconcilable relationship'}

The basis of the relationship between Hong Kong and the Customs was primarily through the CMCS's role as a watchdog of the China coast, regulating trade and collecting revenues. Since Hong Kong was a major entrepot for foreign trade, it often came to the attention of the Chinese Customs. The relationship between the two has commonly been presented as 'irreconcilable'; China's desire to protect her revenue through the agency of the CMCS directly countered Hong Kong's desire to be rid of the Service with their depots and cruisers. ${ }^{2}$ Such assertions are borne out by the fact that the Hong Kong-CMCS issue was the focus of intermittent and tense negotiations for over a 70-year period. Invariably these negotiations 
foundered on the intractability of each party's interests. Despite such a history of unsuccessful negotiations, discussions were revived in 1930. The motivation for the GMD's willingness to re-examine the proposed agreement was their declaration of tariff autonomy (1929), in which greater revenues were at stake. For the Nationalists the implementation of new tariffs had effectively provided the potential for increased Customs revenue. Losses of revenue through smuggling from Hong Kong were therefore increasingly significant.

Hong Kong's waters and the leased territories' inland river systems had long provided a refuge for pirates. ${ }^{3}$ Even during the 1920s and 1930s piracy was a common threat to ships passing through Hong Kong and on to the south-east or to mainland ports. Reports of passengers being robbed or taken hostage and commercial ships being plundered were not uncommon. ${ }^{4}$ No ship was safe from attack. Piracy became so much of a problem that, in November 1928, the Hong Kong and Shanghai authorities dispatched troops to travel on British vessels hoping to encourage any pirate elements to think twice before attacking the ship. ${ }^{5}$ The $C Y B$ for 1926 and 1927 devoted a section to piracy and military interference with shipping. It outlined the details of the Meiren, Dongzhou and Jade piracies among others. ${ }^{6}$ Woodhead, the editor of the $C Y B$, was one of the ill-fated passengers on board the Dongzhou during the attack. The captain was shot and wounded by the pirates who then threatened the passengers. The report wrote of the pirates, 'they insisted upon a course far out from land and evinced murderous intentions every time another steamer hove in sight'. Fortunately no passengers were injured. The CYB for 1929-30 also listed another nine piracies that had occurred. ${ }^{8}$

Smuggling was a large concern for the Service. Discovering hiding places where goods may be stored was a regular activity for Customs staff. C.A.S. Williams, a Customs Commissioner, devoted a chapter in his memoirs to the 'Art of Smuggling'. ${ }^{9}$ He gives a vivid description of smugglers encountered in the course of a career in the Service. Goods could be concealed in the vessel, on the person, in luggage or in boxes, and in baskets with false bottoms. Williams details the strange examples of piglets being drugged and disguised as human infants before being smuggled across borders, a man smuggling diamonds inside his glass eye, a false bottom in a birdcage and hollow bricks. He relates: 'An old Chinese woman boards a steamer at Canton with a basket containing a cat with five newly-born kittens; the mother is very solicitous of their welfare even though they are dead and stuffed with opium!' 10 These ingenious measures were more the exception rather than the rule. The expanse of the China coast remained a challenge for the Service, which battled to maintain and monitor regular avenues for trade. The introduction of China's first National Import Tariff on 1 February 1929 provided the stimulus for the renewed vigour of widespread smuggling. Guangzhou and Hong Kong, by virtue of their geographical, political and economic status became the centre of these illegal operations. ${ }^{11}$ 
Hong Kong's relationship with Mainland China was often underscored with tensions. This is clearly evidenced throughout the Republic and often broke out in conflicts - the Guangzhou-Hong Kong boycotts of 1925-6, for example. As the Chinese sought to regulate and direct trade in the treaty ports through the CMCS, tensions between the Hong Kong authorities, with their laissez-faire outlook on trade, and their Chinese counterparts increased. As early as 1868 the question of smuggling resulted in the fiscal blockade of Hong Kong. ${ }^{12}$ There were renewed negotiations over a proposed Customs agreement with the Colony in 1910 and 1917 also but these met with little success. For the Customs Service the freedom for vessels in Hong Kong's waters had come to represent a thorn in its side.

The CMCS had what could only be described as an ambivalent relationship with the colony. Permitted to have an unofficial Customs office in Victoria and a Customs house in Kowloon in as early as 1886, the CMCS had agreed that the Commissioner would always remain a Briton. ${ }^{13}$ The colony tolerated the presence of the Chinese Customs but never to the extent that it was afforded any official capacity. The Kowloon Commissioner was a visible but superficial concession to the Chinese. With the handing over of the New Territories in 1899, the Service suffered a blow to its prestige as the four stations it maintained therein were closed. ${ }^{14}$ In June 1898 Hart stressed the need for the maintenance of these stations in a letter to Sir C. MacDonald, as it was vital to the protection of China's revenue. ${ }^{15}$ Hart's suggestions were not greeted with enthusiasm and the CMCS, much to its chagrin, was forced to establish Customs posts at the newly drawnup frontiers.

Hong Kong's uneasy relationship with the Service was regularly punctuated by attempts to come to some cooperative venture or, at the least, some understanding of how the waters could be better patrolled. For the CMCS it was a sign of their constancy in trying to serve the Chinese to the best of their ability. The proposed Harris Agreement of 1910, named after the Kowloon Customs Commissioner, sought principally to address salt smuggling by allowing the Customs to function more freely in the Colony. The Hong Kong Government sought to use the proposed agreement as a lever for better negotiation of the Guangzhou-Kowloon Railway Working Agreement. Predictably negotiations surrounding the Harris Agreement were dropped once the Guangzhou-Kowloon Agreement was successfully concluded. ${ }^{16}$ In 1916 the basic premise of the Harris Agreement was again revived. Hong Kong authorities rejected it, however, as they desired more from the agreement. Because of the detailed and localized nature of the proposed Harris Agreement, representatives of the Hong Kong Government and the CMCS carried out the negotiations. The British Minister to China and the Government of China would sign any agreement. As a result the Colonial Office lamented the scant material available for examining the whole question. ${ }^{17}$ 
The CMCS and its relationship with the Hong Kong establishment only receives limited attention in current academic works. Generally the relationship is glossed over in discussions on the development of Hong Kong or its relations with China. ${ }^{18}$ The following section examines the Customs agreement negotiations that took place in 1929 and 1930 between the Hong Kong authorities and the IG. It was under the initially controversial leadership of Maze that these negotiations were once again initiated. At this time Maze instructed Stanley Wright, historian and Customs Commissioner, who was present at the negotiations, to produce a short work outlining the relationship between Hong Kong and the CMCS. This work, Hong Kong and the Chinese Customs, was published as part of the Customs' own publication series. ${ }^{19}$ Maze's motivation for encouraging such a publication was to raise the profile of the negotiations and to put forth the CMCS case from a historical perspective. ${ }^{20}$ The empathy of Governor Cecil Clementi provided a glimmer of hope that the contentious right to patrol the waters would be finally resolved.

Records of the Colonial Office provide a detailed account and discussion of the negotiations that took place between the Service and the Hong Kong Governor. The tenor of the discussions emerges with definite themes: the problem of smuggling, the need for reciprocity with the Chinese, and also concern over any possible changes to the Hong Kong-Chinese status quo.

\section{The proposed agreement}

Manoeuvring the CMCS through the negotiations between the Nationalists and the Hong Kong authorities was a challenge for Maze. The negotiations focused on the right of the CMCS to patrol the colony's waters and in doing so prevent smuggling to the China coast. A definition of the boundaries of China trade was integral to negotiations but intrinsically difficult to achieve. Dialogue between the interested parties often foundered. For Maze the proposed agreement marked the launching of the Customs on a course much more sympathetic to GMD aspirations.

The actual motivations for reviving negotiations between the Service and Hong Kong are almost lost in the discussions that followed. In the British Foreign Office's Annual Report for 1929, Lampson commented that in response to the alleged increase smuggling that had been largely inspired by the increased tariff of 1929, the National Government deputed the IG to proceed to Hong Kong during the summer to negotiate the agreement. ${ }^{21}$ Wright, moreover, credited Maze with the initiative for not only the trip to Hong Kong but also the customs agreement that was to be discussed. ${ }^{22}$ On 24 June 1929 Maze had submitted a memorandum to the Chinese Government on the subject of smuggling and the measures he believed were necessary to protect revenue..$^{23}$ In this document Maze outlined that the new tariffs had not only given greater impetus to smuggling, they were also beginning to lead to more desperate measures being 
taken by smugglers. The Kowloon and Lappa districts were listed among those he felt needed to be specially guarded. ${ }^{24}$ Throughout the Republic Customs launches had often engaged in preventive work, boarding and inspecting vessels, but Maze noted that in recent times Customs launches were experiencing increasing difficulty in gaining the cooperation of these vessels. When approached, some vessels ignored Customs signals or, in extreme cases, resorted to gunfire when challenged. Maze cited the case of revenue launch Yangxing, operating from Kowloon. When approaching threesuspicious-looking junks, this launch was fired upon without warning and sustained minor damage. ${ }^{25}$ By arming Customs vessels with better equipment and allowing them to return fire when met with resistance, Maze maintained that smuggling in the Kowloon area could be combated. Furthermore, he believed such moves were a good preparation for the negotiations with Hong Kong, which he would soon be entering into.

In conjunction with the proposals regarding the development of a preventive service that was agreed to in principle by the Chinese Government, Maze arranged to enlist a Commissioner to investigate the areas where smuggling was rife. ${ }^{26}$ This was with the intention of seeking possible solutions to the problem. In his view the development of a better-equipped preventive service did not hinge solely on the success of the Hong KongCMCS negotiations. In a display of farsightedness, Maze intended it would have a significant impact on smuggling regardless of the outcome of the agreement. Before any investigations could take place, however, Maze travelled to Hong Kong to initiate negotiations for a Customs agreement.

During the course of this visit in July 1929 Maze suggested that the previously discarded Harris Agreement could be used as the basis for renewing discussions. A Colonial Office report indicated that Maze had intimated that there might be a tightening of a Chinese cordon around the colony should no agreement be reached. ${ }^{27}$ The basic premise of the Harris Agreement was that of permitting the CMCS to function freely within the colony and surrounding waters to prevent smuggling. In return for such concessions, however, the Hong Kong authorities wanted the right for ships under the British flag to have permission to trade between Hong Kong and non-treaty ports. Further to this Governor Clementi made it clear that, apart from wanting inland water privileges for the colony's steam vessels, he wanted a clause inserted protecting Hong Kong's coastwise trading privileges in all circumstances. ${ }^{28}$ From the outset Maze responded that any such clause would render the proposal unfavourable to Chinese interests.

A conference was held at Government House on 19 July. The purpose of this conference was the renewal of negotiations surrounding the proposed agreement of 1918. Hong Kong was represented by Governor Clementi; W.T. Southorn, Colonial Secretary; Sir Joseph Kemp, AttorneyGeneral; Commander G.F. Hole, Harbourmaster; and J.D. Lloyd, Superintendent of Imports and Exports. ${ }^{29}$ The Governor also requested the attendance of the British Consul in Guangzhou, G.S. Moss. China was 
represented by the Customs. C.F. Johnston, Commissioner of Customs at Kowloon district, and Stanley Wright, Commissioner, accompanied IG Maze. ${ }^{30}$ The 1918 draft was discussed in detail and a small committee was appointed to make the amendments suggested by the conference. The conference met frequently for discussions throughout the following week. A second conference was held on 29 July where further amendments were made to the draft of the proposed agreement. ${ }^{31}$

After these amendments the Hong Kong representatives were satisfied with the agreement. Maze then submitted it to the Chinese Government for consideration..$^{32}$ The most contentious article in the 1929 draft was Article V, which related to inland shipping privileges for Hong Kong. This clause had been present in a shorter form in both the 1910 and 1918 proposals, and both times the Chinese had been prepared to accept this clause as part of agreement. By 1929, however, the political climate in China had changed. Wright detailed:

China had undergone a re-birth, and the strong spirit of patriotism, which was manifesting itself all over the country, was strongly opposed to the granting of any privileges to foreigners which were derogatory to the fact or feeling of national sovereignty. ${ }^{33}$

The Chinese maintained it was difficult for Hong Kong to demand privileges that may soon be removed from Britain. Despite the conference's initial promise, it rapidly became apparent that negotiations had reached a deadlock, with the GMD proposing to omit Article V and Hong Kong's authorities not wanting further negotiation unless the clause remained in place.

The Hong Kong authorities' response to the proposed agreement was predominated by self-interest. In their eyes the issue rested, as it had always been, on the side of Chinese concerns. A simple granting of permission to the Customs to patrol the colony's waters held no tangible benefit for Hong Kong. Therefore the Governor was motivated to seek some benefits out of the agreement. The Colonial Office report notes:

Throughout all of these intermittent negotiations, the attitude of the Hong Kong Government has invariably been that it is the Chinese who are bent on concluding the agreement, while the colony is comparatively indifferent to the main (i.e. Customs) issue. It is therefore up to Hong Kong to secure the maximum advantages in return. ... If the bargain is not good enough, the Colony will drop the question one [sic] more. ${ }^{34}$

It was this rationale of optimizing their benefits that prompted British demands for their shipping to be granted privilege to trade at non-treaty ports in exchange for its concessions to the CMCS. The Hong Kong authorities considered they were in an advantageous position in these discussions as they viewed it was the Chinese who had always wanted such an agreement. 
Early negotiations were compounded by concerns over the possible ramifications for Hong Kong should an agreement not be reached. This is certainly a change from Hong Kong's position when the Customs agreement had been dropped rather unceremoniously by the authorities years earlier in 1916. Hong Kong authorities, when faced with Nationalist China, began to realize they were no longer in a position simply to discard negotiations after obtaining what they wanted from the Chinese Government without any reciprocity. Maze took great pains to explain his and the CMCS's position in the negotiations. Furthermore, he protested that he did not want to be mistaken as threatening Hong Kong's authorities but rather urged them to be aware of the possible ramifications should Hong Kong reject the agreement. He wrote:

it is idle to shut our eyes to the fact, and it should be clearly understood that if the Agreement is definitely turned down, the Customs will establish a very stringent - and for China a very expensive 'Preventive cordon' round Hong Kong and the Leased Territory - not with a view to crippling the Colony's trade, but - merely in order to protect as far as possible China's Revenue. ${ }^{35}$

Maze's tone in this letter is clearly threatening. He alluded to the CMCS's resolve to act against any attempts to thwart the negotiations. A preventive cordon around Hong Kong would allow the Service to protect China's interests and, unfortunately, the colony would be hurt as a result.

Documentation of the negotiations is incomplete and often sketchy. The Colonial Office provided an overview and discussion of interested parties and their motivations in either supporting or opposing the agreement. The Foreign Office papers reveal much of Lampson's reaction to events. Surprisingly, in the volumes of Customs documents, Documents Illustrative of the Origin, Development and Activities of the Chinese Customs Service, there is no mention of the Customs Agreement. In a further, most intriguing twist, correspondence between Maze and the London Office's (LO) NonResident Secretary (NRS), Stephenson, discussed instructions that all confidential correspondence pertaining to the agreement were to be permanently removed from the Office. Stephenson reported to Maze:

With regard to the Confidential and Private Letters which you have sent me since January 1929, these have always been kept entirely apart from all other correspondence in a drawer specially reserved for the purpose under lock and key together with the corresponding Confidential and Private Letters from myself to you. I have now carefully removed from this drawer every Confidential and Private Letter received from you or sent to you and there is now in this Office no record whatever of this correspondence $[$ sic $]$.... Other Confidential Telegrams from yourself - e.g. concerning the Hong Kong Agreement 
- in which references were made to your Confidential Letters and opinions expressed with regard to 'actions and attitudes', and those from myself communicating to you messages of a similar nature - telegrams which had been entered in the Telegram Book - all of these have been removed from the book without any mutilation or disfigurement. ${ }^{36}$

As a result of this secrecy the following exploration of the unsuccessful negotiations is sometimes necessarily sketchy. But overall it is clear that, despite the delicacy of these negotiations, Maze was actively pursuing GMD interests.

The proposed agreement inevitably attracted a bevy of lobby groups both within and outside China who were eager to weigh into the negotiations. The Colonial Office and Maze, at varying stages, outlined these lobby groups and their stance on the proposed agreement. In this regard the lobby groups must have been considered significantly vocal and therefore their views given some attention. A brief listing of these groups is as follows: the Foreign Office, Colonial Office and the Consul at Guangzhou, the IG of Customs, the Hong Kong Government, Shanghai Chamber of Commerce and the China Association. All of these groups were known to have interests in the development and outcome of any negotiations. ${ }^{37}$ What becomes apparent in the documents relating to this event is that not only were the main players important, but there was a heightened awareness of the lobby groups. These latter were increasingly vocal as regards the negotiations, particularly those that focused on the territorial 'reach' of the CMCS.

In October 1929 Maze enlisted Commissioner Bell to investigate the frontiers of China (particularly Kowloon and Lappa) with reference to smuggling. ${ }^{38}$ In a Customs circular he urged all Commissioners to give Bell their full support and he also requested that they examine their local region and submit recommendations of preventive measures if they believed smuggling had increased in the area. ${ }^{39}$ Between 25 February and 28 March 1930 Bell conducted a South-East China Coast Investigation Commission. ${ }^{40} \mathrm{He}$ embarked on the revenue steamer Bingjing and was accompanied by Customs staff and Chinese delegates from Guangzhou and Fuzhou. ${ }^{41}$ In the course of the investigation, at Bell's instruction, 24 motor vessels, 12 steam vessels and 24 seagoing junks were boarded and searched. As a result six of the motor vessels were seized. Japanese nationals owned five of the vessels found to be engaged in direct foreign trade to inland waters. ${ }^{42}$ At Xiamen, Bell ordered a raid on the island of Wusu, which was supported by a Chinese gunboat Zhujian and troops from Xiamen. ${ }^{43}$ This raid uncovered a smuggling ring, a Japanese vessel was held and goods were confiscated from buildings.

Bell's findings following his investigation were mixed. He believed the Customs needed a closer working relationship with the native Customs service if smuggling was to be effectively countered. ${ }^{44} \mathrm{He}$ also found that 
laws regarding junks trading with foreign ports (Formosa in particular) needed to be clarified, and also that motor vessels should be classified as steamers and therefore they would need more detailed paperwork and to carry a copy of their manifest. Bell recommended that all vessels within 12 miles of the Chinese coast or islands could be liable to be searched. At the same time, though, he admitted that his own views had modified as regards the extent of the smuggling blight. Bell recorded:

While the possibility of smuggling to a heavy extent exists, it is to be doubted if it is availed of to the extent that might be supposed. For from the profits gained by evasion of a high tariff there must always be deducted much on account of risk of piracy while on the water and banditry ashore. ${ }^{45}$

This was not a denial that smuggling was a problem. The 'unending panorama of rugged bays and well-concealed coves' meant smuggling could never be completely eradicated and Bell's investigation had led him to scale down his perceptions. In addition Bell commented that, while he thought preventive measures were necessary, the proposed arming of harbour launches was unwise. He believed this would invite attack and unless staff were all extremely disciplined and well-trained it could lead to some "unpleasant incident' ${ }^{46}$ This report was well received by Maze and the Government. It confirmed for Maze that smuggling was indeed a constant problem along the southern coast but measures to counteract this were, however, unresolved.

Maze did not find British circles sympathetic to the CMCS attempts to address the smuggling problem. From the outset and as negotiations stretched into 1930, Lampson was not won over by the supposed urgency of the discussions. He was not convinced that the GMD really needed the proposed agreement to be hurried along. The Minister, moreover, expressed a suspicion that smuggling was not as urgent a concern as Maze would have the Foreign Office believe. ${ }^{47}$ Lampson saw the Hong Kong-CMCS agreement as hinging on two points: how far was it in British interests that such an agreement should be concluded? And what disadvantages would there be for Hong Kong should the CMCS be allowed to function? ${ }^{48}$ In line with this advice from their man in China, the Foreign Office viewed the need for an agreement as being more an exercise in good relations with the Chinese Government than to really provide any benefits to Hong Kong. There is no evidence that Bell's report was made available to the Office.

The Foreign Office approach to the proposed agreement attempted to take into account the wider significance of negotiations. The Foreign Office perceived Hong Kong's authorities as having a narrow view of the proposal and therefore missing the fact that reaching an agreement would be beneficial to all British interests and relations with Nationalist China. It would be responsible for 'removing a legitimate source of grievance as regards smuggling, and strengthening the value to China of the foreign staffed 
Customs administration' ${ }^{49}$ The Foreign Office also maintained that a successful conclusion would bolster the foreign inspectorate of the Customs. Significantly the potential loss of face to the Customs should negotiations fail received no mention elsewhere. Maze's leadership had not heralded the demise of the foreign Inspectorate of the Customs as feared by Lampson and the Foreign Office. Indeed the Service appeared to have been strengthened in its relationship with the GMD. It appeared, therefore, that the Foreign Office believed that precipitate action in suspending discussions should be avoided in the interests of the Service.

As discussed previously the most contentious aspect of the proposed agreement was that which granted British shipping special privileges. Under Articles V and VI, ships and junks trading under the British flag would be permitted to trade at all non-treaty port locations along the China coast. As a proviso for inland trading rights, these ships had to register with the Customs before being permitted to trade. In response to this contentious demand, the Chinese offered a compromise that inland trading rights would be granted to vessels that were prepared to trade under the Chinese flag. Unprepared to run the risks of trading under a Chinese flag, Hong Kong authorities reduced their claims to limiting British ships to the coasts of Guangdong and Guangxi. They saw the rights of inland navigation to the Guangdong and Guangxi provinces as an essential element to the success of the agreement. ${ }^{50}$ Furthermore they requested that privileged factory treatment be granted to Hong Kong manufactures. Maze's thoughts on the contentious articles were much more pragmatic. As Hong Kong steamers at the time had no rights to the inland waters, he then reasoned that omitting Article V from the agreement would be no loss for the authorities; they could not lose a right that they never had. ${ }^{51}$

Sir Cecil Clementi, regarded as sympathetic to the CMCS, gave his farewell address to the colony in January 1930 and was replaced as Governor by Sir William Peel in May $1930 .{ }^{52}$ An NCDN article detailed the 'important problems' that Peel was already attempting to address: the trade slump due to a decline of the silver dollar, concerns over tax increases and possible constitutional reform. ${ }^{53}$ There was no mention of the new Governor turning his attention to the ongoing Hong Kong-China Trade and Customs Agreement negotiations. In a secret telegram from Peel to the Secretary of State for the Colonies, it is apparent that Peel was not only well aware of the ongoing negotiations but that he was inclined to be dismissive. After reading through the files and in consultation with his advisers, Peel declared:

I find myself entirely opposed to the suggested agreement. I consider it to be most undesirable to allow China to operate a preventive service in the waters of the Colony. I strongly recommend that as conditions set out by us in draft agreement are unacceptable to Chinese Government proposed agreement be dropped. ${ }^{54}$ 
Peel's denunciation of the proposed agreement has been cited by WesleySmith in Unequal Treaty as the main reason for the ultimate failure of the negotiations..$^{55}$ This is not, however, an accurate understanding of Peel's role in events. Negotiations were suspended by mid-1930 as a result of internal unrest in China and Peel's reluctance to leave the agreement as it stood. This did not mark the end of discussions and by October Maze and Peel were able to devise a much more mutually agreeable proposal. When the Customs Agreement issue was raised again in 1935 (with a similarly unsuccessful outcome), Maze wrote of Peel's retirement with regret. He believed the Governor had been an 'invaluable support' ${ }^{56}$ Clearly, then, Peel was not the main stumbling block in the discussions.

Negotiations around the proposed agreement had already become contentious by the time Peel arrived as the new Governor. Lampson expressed his suspicion towards granting any leverage to the 'Chinese irredentists', whom he believed would utilize such concessions in campaigning for the return of Hong Kong to Chinese control. In a discussion with Swire ${ }^{57}$ and Teichman, ${ }^{58}$ Lampson revealed something of the confusion that had rapidly surrounded the agreement:

As regard the Hong Kong Customs Agreement, I told him that, like other people who had anything to do with the wretched question, I had quite frankly wobbled in my opinions. ... I might be oversuspicious, but I felt instinctively that we should be very chary to agreeing to anything which would give a handle to Chinese irredentists in the campaign which I felt certain would increase as time went on for the handing back to China of the Colony of Hong Kong - a matter on which I trusted we should always firmly dig our toes in. ${ }^{59}$

For Lampson one of the overriding concerns was trying to balance interests. In doing so he thought it was preferable to create some type of preventive service without compromising the position of Hong Kong as a British colony. In the same entry Lampson referred to Governor Peel as being 'genuinely anxious' to resolve the question.

As negotiations came to a standstill, the $N C D N$ sought to keep the issue in the public eye. The significance of the proposed agreement, according to a May editorial, was that these negotiations were anything but localized. ${ }^{60}$ Possibly in a bid to ascertain Peel's stance on the Customs issue, the $N C D N$ presented the pending agreement as a concern for all foreign shipping in China. The China Association ${ }^{61}$ received criticism for seeing 'no harm' in the agreement, this error in judgement being attributed to the Association receiving guidance from Sir Francis Aglen. The editorial questioned Aglen's ability as an adviser commenting, 'without disrespect, it is scarcely possible for him to consider this issue from any but the Customs point of view'. ${ }^{62}$ This provocative editorial declared that the proposed agreement would not only affect all foreign shipping at the treaty ports 
but would have moved towards 'an eventual demand for the surrender of Hong Kong'. The implication of such comments was that the Service was perceived as a lever for the Nationalists to achieve their territorial ambitions. The CMCS was taking on a new role as an instrument through which the Nationalist government could battle against the foreign powers.

The negotiations surrounding the proposed agreement were immeasurably complicated by internal unrest in China. The Nationalists, while ostensibly leading a united China, were beset with internal dissension, primarily in the form of warlords who had accepted GMD leadership in the face of the Northern Expedition but did not intend to allow any decline of their own power. Warlords Feng Yuxiang and Yan Xishan formed a northern alliance against Jiang Jieshi and in June moved in open challenge to the GMD. Such challenges to both the GMD and to the Customs resulted in the suspension of further work on the agreement.

By late September, with the political and CMCS situations in the north returned to GMD control, negotiations were once again initiated between Hong Kong and the Customs. In a letter to NRS Stephenson, Maze detailed that, through Lampson, he had learnt that Hong Kong was in general agreement with revised proposals. After further redrafting, Maze commented that Lampson's 'views on the subject now harmonise with mine'. ${ }^{63}$ Copies of the draft were issued informally to the Foreign Office, the Colonial Office and the Chinese Minister in London. ${ }^{64}$

In October 1930 Maze journeyed to Hong Kong to continue discussions with the Hong Kong authorities. The NCDN reported the IG's impending travel and that it was understood that he would seek to create a satisfactory arrangement that would bring an end to smuggling in the South. This, in turn, would therefore mean greater revenues for Guangzhou. ${ }^{65}$ In response to this journey Maze alerted NRS Stephenson that his services might once again be needed in the East. Maze predicted that Stephenson would be installed as Commissioner at Kowloon since the agreement had good probability of being accepted. The Kowloon post, in Maze's estimation, needed skilful administration as it promised to be one of 'considerable delicacy and importance' ${ }^{66}$ Maze's journey ended in success, which he celebrated in a note to Sir Newton Stabb:

Peel and I have arrived at a complete understanding concerning the proposed Hong Kong Agreement and I understand that the Nanking Authorities are also prepared to accept my final recommendations in this connection. I trust, therefore that there will be no more hitches and that this tedious and troublesome question will be settled satisfactorily once and for all. ${ }^{67}$

This was a personal success for Maze. His guidance of the Service was further confirmed as the right kind of leadership. Moreover, he viewed the pending conclusion of the agreement as a strengthening of his position. ${ }^{68}$ 
By 31 October Maze and Peel had reached a satisfactory settlement over the proposed agreement. ${ }^{69}$ The final test was its being found acceptable to both the Nanjing and British governments. The agreement's final form avoided the controversial demands for an exchange of mutual concessions and instead focused on cooperation. Lampson, who, as early as June, had formed the opinion that the agreement as it stood would never be agreed upon, had predicted such a shift away from earlier versions of this document. He recognized that the atmosphere surrounding the discussions had become embittered and believed that the only chance of success would be to drop the agreement as it had stood and to concentrate on a preventive service alone. ${ }^{70}$ Lampson also shared Maze's optimism for a successful conclusion and anticipated that the revised proposal of the agreement would remove longstanding grievances between the Chinese and the colony. ${ }^{71}$

The final draft of the proposed agreement (6 November 1930) was both a compromise and reduction of the original demands of the interested parties. $^{72}$ This agreement focused primarily on preventive measures and the contentious articles granting privileges to vessels under the British flag were removed. Articles I through $\mathrm{V}$ addressed the status and conditions for Customs staff directed to Hong Kong. Essentially Customs staff would be treated as seconded employees and would operate under instruction from the Hong Kong Superintendent for Imports and Exports. Articles VI through XI dealt with the categories of vessels and their obligations to present a manifest of cargo and to pay the relevant duties to the Customs authorities when necessary. Article XII focused on salt, its importation, exportation and production. A permit for salt exportation had to be obtained from the Salt Department and then countersigned by the Commissioner of Customs. Article XIII forbade any person in Hong Kong to have dynamite or explosives; such substances could not be stored without a permit. Possibly this article was an attempt to stop smuggling of arms and also to discourage piracy. Article XIV allowed the Customs Commissioner to maintain an office in Victoria but no substations elsewhere (basically the situation remained unchanged from Hart's era).

Articles XV, XVI and XVIII are most significant in shaping the nature of the agreement. The limitations of the draft become apparent as these Articles set the parameters for CMCS involvement in Hong Kong. Article $\mathrm{XV}$ essentially defined the limit of the Customs' preventive service to Chinese waters only:

Except in special cases where, after consultation between the Commissioner of Chinese Customs and the Superintendent of Imports and Exports, joint operation are decided upon, revenue vessels of the Chinese Maritime Customs functioning in Chinese waters and revenue vessels of the Colony of Hong Kong functioning in Colonial 
waters shall not use each other's water in the exercise of preventive duties. $^{73}$

This article is significant as it effectively negated one of the Nationalists' main demands for the Customs to have access to the colony's waters. By not allowing the CMCS to patrol their waters, Hong Kong was protected from any possibility of becoming another treaty port. For the Customs this article meant they had to be prepared to work in conjunction with Hong Kong authorities to prevent smuggling. While not being what was originally envisaged, this cooperation was at least recognition of their concerns. Article XVI stipulated that Chinese or foreign goods passing through Hong Kong to or from a treaty port with Customs documents could maintain their original status, in this way avoiding any additional tariffs for reimportation of goods or products to China. In this way the colony was gaining the benefit of treaty port trade without actually being a treaty port or having to adhere to the obligations of having the CMCS present in their waters. Article XVIII further emphasized cooperation between the CMCS and Hong Kong authorities in each being responsible in trying to prevent smuggling in their waters. The agreement was to be ratified for a five-year period, unless re-negotiated by both parties concerned (Article XXIV).

\section{A dead letter: the failure of negotiations}

The idea that the Chinese Maritime Customs Administration can remain in a water-tight compartment and function independently of the Chinese Government in these latter-days is fantastic, not to say stupid. But if we are prepared to accept the limitations which fact places upon possibility, I believe that the life of the quasi-foreign Inspectorate can be prolonged to the advantage of foreign trade, shipping and finance.

Frederick Maze ${ }^{74}$

Maze believed that continued negotiations were dependent on the Nationalists' support. Despite the promising outlook of the November draft of the agreement, negotiations failed. The Nationalist government rejected the draft and, in doing so, destined the Hong Kong-Customs issue to many more years of speculation and negotiations. The failure of the agreement stemmed from the controversy surrounding the 'free port' of Zhongshan. Despite silted approaches and poor water levels, it had been opened as a 'free port' in July 1930. This was after intense lobbying on the part of locals. ${ }^{75}$ There was no Customs tax on goods consumed within the port area and smuggling was rife. The Zhongshan scheme was a huge liability for the Chinese Government and the Customs. Song Ziwen visited Guangzhou in October following Maze's reports of smuggling and found confirmation of this illegal trading through various sources. In response 
Song instructed Maze to close the duty-free area ${ }^{76}$ Maze noted that Song's irregular action had raised a storm of protest in Nanjing. The Zhongshan Deep-Water Scheme was a project of dubious merits that anticipated this free port would supplant Hong Kong as a leading entrepôt. Many high Guangzhou-based officials had personal interests involved. ${ }^{77}$ They became convinced that the closure of Zhongshan was more a contrivance of Hong Kong interests than being revenue related and therefore directed their displeasure towards the ongoing Hong Kong-Customs Agreement.

The closure of Zhongshan was the catalyst for the failure of the proposed agreement. Maze wrote of the agreement as being a total loss as the 'Guangzhou Party' had raised objections. ${ }^{78}$ Anger at the reactive response to Zhongshan emerged at the Fourth Plenary Session in Nanjing where the Guangzhou Party rejected the proposed agreement and in particular the concession in Article XVI ${ }^{79}$ (this article granted goods passing through Hong Kong treaty port status). This faction's claim was that such an agreement would adversely affect the trade of Guangzhou. Such a claim runs counter to the basic premise of the agreement, which was to prevent smuggling and therefore benefit the south with extra revenue. What these Guangzhou interests (including Tang Shaoyi, who was mentioned on several occasions in the Maze Papers as being a prominent supporter of Guangzhou-based interests ${ }^{80}$ ) resented was any checking of smuggling in Zhongshan and the proposed agreement would have further restricted such illegal trades.

The furore that erupted over Zhongshan left Song attempting to justify his actions. On Song's instructions Maze had closed the Zhongshan area but Song, in a bid to extract himself from criticism, attempted to blame the CMCS for having acted without proper instruction. Displaying clarity of judgement, Maze had deliberately not acted until he had received written instructions. ${ }^{81}$ In this instance he had avoided allowing the Customs Service to be drawn into political entanglements. Although the agreement was not concluded, in the 70-odd years during which it had been a contentious issue, 1930 was the closest it had come to achieving success.

The failure of the Hong Kong Agreement was a resounding blow to the good offices of Maze, who had faithfully orchestrated the negotiations. He received commiserations from the British Foreign Office and from others interested in the China situation. As Maze reflected:

It is disheartening, of course, to see the work of a year destroyed in this manner, but such things happen in China (and elsewhere) and we must bow philosophically to the fact. I did my best to get the agreement passed, and no man can do more than his best ${ }^{82}$

The Foreign Office gave Maze's role in the negotiations indirect praise as they sympathized with him when negotiations stalled. Blame for the breakdown was placed squarely on the Chinese, who were presented as irrational 
in the face of generous foreign response. Lampson shared Maze's frustration at Song's ill-judged actions regarding the Zhongshan Deep-Water Scheme and maintained it was a most regrettable outcome. According to the Foreign Office's 1930 report, Lampson asserted that the Hong Kong Government had gone a long way to meet the Chinese on this issue and that he was not personally prepared to press them to make further concessions. ${ }^{83}$

The Hong Kong-China Trade and Customs Agreement entailed complex and delicate diplomacy. Maze's leadership of the CMCS was reaffirmed even though the agreement was not successful. Maze had shown his skill as a negotiator and had made it clear to both the Nationalists and the British that he would not avoid his responsibilities as IG or as an employee of the Chinese Government. In a letter to Sir Newton Stabb, Maze asked:

I sometimes wonder, indeed, if you, and others in London who are interested in China, realise exactly just how difficult it is in these latter days - not merely to maintain the quasi-foreign Inspectorate, but to actually broaden the Customs' influence? ${ }^{84}$

Such questions confirm Maze's perception of his leadership as a crucial one for the Service. Through his active participation in the agreement, Maze was heralding a new course for the Service. By shifting away from Aglen's semi-independent stance and overriding foreign interest bias, Maze was leading the Service into a more ambiguous position as he tried to balance Chinese and foreign interests. While Maze may not have found calmer waters for the CMCS, he had turned the Service to run with the tide of events in China rather than against it. 


\section{A Service in decline}

The Republican era presented numerous challenges to the security of the CMCS but 1930 onwards marked a gradual deterioration of its position in China. Challenges to the Service during this time were twofold: that of internal dissension as Jiang Jieshi struggled to maintain dominance against disaffected warlord and communist forces, and that of Japanese aggression in the north-east. These internal and external forces afflicted the Service in the form of the Tianjin Customs takeover in June 1930, the demands against the Guangzhou Customs by Southern insurgents in 1931 and finally in the takeovers of north-eastern Customs houses by the Japanese in 1932. The Customs faced the possibility that these dangerous precedents would ultimately destroy its administration. During these challenges to the Service, Maze continually drew on the assertion that the Customs needed to stay out of politics to ensure its survival. In seeking to keep the Service separate from the stresses that were buffeting the Nanjing Government, Maze believed he was returning to the vision of his uncle, Hart. Furthermore he believed that Hart was the only Inspector General (IG) who had possessed 'real power' but he wisely had not paraded it. ${ }^{1}$ Such comments reveal that Maze may have been not only seeking to emulate his uncle's leadership ideals but, in doing so, hoped to attain a measure of his legendary influence in operating behind the scenes. The case studies of this chapter, however, reveal that Maze's vision was unrealistic and that his position as IG was not as influential as he may have wished.

Despite the numerous challenges confronting the Service from 1930 onwards, the Customs Service did not collapse. It existed in name, if not in a coherent form, until 1949. After 1937 the Service was, moreover, only a shadow of its Imperial and early Republican forms. This chapter explores the earliest indicators of the atrophy of the CMCS and its fragmentary state prior to 1937.

This chapter examines case studies of incidents that had significant impact on the functioning of the CMCS, namely the Tianjin Customs Seizure in 1930, claims against the Guangzhou Customs in 1931 and then the Japanese claiming of northern Customs houses from 1931 onwards. The Tianjin Customs seizure arose primarily out of warlord (Feng Yuxiang 
and Yan Xishan) opposition to the GMD and more specifically Jiang Jieshi's dominance thereof. This takeover of the Customs house created a dangerous precedent for the possible dismembering of the Service. Dormant tensions between Maze and British Minister, Lampson, appear to have resurfaced as Maze responded to what seemed to be British inertia to the Tianjin impasse. Again in 1931 the Service faced a direct challenge through a southern-based faction of the GMD and their claims against the Guangzhou Customs revenue. In this instance a compromise was effected. The Japanese Guandong (Kwantung) Army's ambitions and aggression in north-eastern China had long been known to China and to other foreign powers. So too the Japanese had shown themselves to be seeking larger influence in the Customs. During the succession crisis (see Chapter 4) they had been angling to promote their own nationals into better vantage positions in the Service. The Manzhuguo Government's seizure of the northern Customs houses in 1932, with the tacit approval of the Guandong authorities, posed a serious threat to the existence of the Customs.

\section{The Tianjin Customs seizure: an overview}

On 16 June 1930 the Commissioner of Tianjin Customs house, Bell, was called on by a delegation of local Chinese and foreigners who presented him with an order removing him from office. Warlords Yan Xishan and Feng Yuxiang had allegedly enlisted Western journalist Bertram Lenox Simpson to sequester the Customs house on their behalf, as protracted negotiations with the GMD for access to these funds had proved unsuccessful. Yan and Feng claimed they would amass the revenue surplus until their civil war against the Nanjing Government reached some conclusion. In response Bell retreated with his staff to the British Concession. Maze declared Tianjin a dead port and trade was redirected. Simpson, acting on the behalf of the northern warlords, reopened a self-styled Customs house that functioned until September 1930. This de facto establishment was tacitly recognized by the foreign powers, allowing their nationals to continue trading. This new establishment was however thwarted when Zhang Xueliang, the Manchurian warlord, moved in favour of the GMD and reclaimed the Customs house. Simpson's retention as Commissioner until a replacement was arranged was disastrous as unknown assailants assassinated him. With Zhang's mobilization of troops in support of the GMD, Feng and Yan's campaign against Nanjing had been crushed. The stakes in the conflict had been high and, by late October, Feng's career as a warlord was finished and a chastened Yan was brought under Jiang's control. The Customs emerged intact but unsettled by the relative ease with which the warlords had been able to wrest control from the Customs administration.

Physical attacks or threats against the Customs Service were not unknown throughout the Republic, but what set the events in Tianjin apart was that the Customs house was taken over and a de facto administration 
created. The June 1930 seizure of the Customs was an unprecedented, but not entirely unexpected, chain of events. On appraisal of the Customs documents and incidents prior to the Tianjin seizure, it is indisputable that the threat of such an attack had been looming for many years. Ever since Sun Yatsen's threats against the Guangzhou Customs in 1923, there was always the possibility of such actions being emulated with more success. In actuality many warlords (Zhang Zuolin and Feng Yuxiang, for example) sought to curry favour with the treaty powers in a bid to enhance the legitimacy of their claims for control of China. ${ }^{2}$ With control of China came access to the surplus revenue of the CMCS. Until 1930, however, not even the GMD had threatened to wrest control of the Customs houses from the Inspectorate's control.

The takeover of the Tianjin Customs was the culmination of increasing tensions between the Yan-Feng alliance and the GMD. The relationship between Yan and Feng was primarily one of political expediency. The threat that united the northern warlords was Jiang's ensuring of GMD dominance at the necessary expense of the warlords who collaborated with the GMD forces during the Northern Expedition. ${ }^{3}$ Both Yan and Feng had sought membership of the GMD and, with their forces, assisted Jiang in the final stages of the Northern Expedition. The overarching premise for this alliance can be found in the adage 'if you can't beat them, join them': survival instinct led the warlords to hoist the Nationalist banner. Their membership of the GMD, however, was a necessarily tenuous alliance, as neither wanted their power diminished. Feng's abandoning of the GMD in May 1929 was in response to Jiang's push for demilitarization and his repositioning of troops into Shandong to curb Feng's ambitions for the region. Essentially Feng and Yan's alliances with Nanjing were opportunistic, guaranteeing the maintenance of their forces. Throughout their careers both had encouraged the systematic indoctrination of troops making it relatively simple to incorporate GMD ideologies of nationalism and anti-foreignism. ${ }^{4}$

On 10 October 1929 leading Guominzhun* officers addressed a public telegram to Feng and Yan, denouncing Jiang Jieshi. They urged the warlords to take action (having subordinates asking their leader to do what he already wanted to do was a technique commonly used by Yuan Shikai during his consolidation of power). ${ }^{5}$ In February 1930, after a short time of neutrality in which Yan was appointed as second only to Jiang in the campaign against Feng (but Yan was unwilling to fight against the warlord), ${ }^{6}$ Yan announced his alliance with Feng. For Yan the alliance was purely calculated for survival. Should Jiang have defeated Feng little would then stand in the way of the Nationalist forces under Jiang attacking his own power base. Yan's support for Feng was initially shrouded in discussions of the joys of travel they would share together, ${ }^{7}$ a cryptic expression of solidarity for Feng's cause.

\footnotetext{
* Feng's National People's Army.
} 
The essence of Yan and Feng's dispute with the Tianjin Customs related to the continued remitting of surplus revenue for the Nanjing Government's disposal. In late April Yan challenged Commissioner Bell and demanded that surplus should be placed in a Tianjin bank, the Bank of Communications, until the civil unrest reached a conclusion. Bell responded, after instructions from the IG, by dismissing the Bank of Communications as the Customs Bank on 5 May and directing that the surplus be remitted directly to the IG's control. ${ }^{8}$ Negotiations were initiated but, according to Foreign Office reports, Bell's attitude needed to be far more conciliatory towards the northerners' demands than it was. During May Lampson recorded how important he believed it was for Bell to convince local authorities that he was indeed prepared to work towards a suitable compromise. ${ }^{9}$ It appears that despite such advice from the British Foreign Office and an official Customs stance of non-intervention, Bell took a tough approach and negotiations were difficult. In response to this frustration and true to his dynamic warlord predilections, Yan ordered the takeover in June. ${ }^{10}$

From this brief account of the origins of the dispute it becomes apparent that the Customs and the Consular powers were forewarned in early May of the threat to the Tianjin Customs house. It is significant then that Yan and Feng's forces hesitated to put this plan into effect. In a letter between Maze and Non-Resident Secretary (NRS) Stephenson dated 24 April 1930, there was a discussion of Yan requesting Edwardes to raise a loan and to travel north with it. ${ }^{11}$ Maze recounted this as not being too surprising as Lampson had encouraged Yan to support Edwardes' claim to the position of IG in 1928. While this claim is not mentioned in other sources, this letter reveals that Yan was pressed for funds. Since no loan was raised in support of this request, the situation would have deteriorated as time passed. It is possible that, in the six weeks of negotiation that elapsed between reports of Yan's intention and the actual takeover, the northern forces were assessing foreign reaction to the threat. The Customs' own reports support the probability of the northern warlords' watchfulness over the Customs, as in the weeks between the threat and the takeover representations to the Tianjin Customs were made by Chinese supporters of Yan and Feng. These delegations included reasonably prominent local figures, including the secretary to the Mayor of Tianjin and secretary to the Garrison Commissioner. Bell successfully fended off these 'diplomatic' approaches. ${ }^{12}$ The American Consul in Tianjin, Gauss, described this watchfulness on the part of the warlords as Yan and Feng not having 'gathered sufficient courage to resort to drastic action'. ${ }^{13}$

The economic strength of the Tianjin Customs and its important contribution to Chinese Customs revenue was a significant motivation for its being coveted by the northern warlords. Of the 180,619,758 (Hk.Tl) that formed the total Customs collection for 1930, Tianjin represented 7.32 per cent of this contribution. ${ }^{14}$ While not seemingly huge revenue, Tianjin's contribution was second only to Shanghai, the undisputed giant of the 
Chinese ports. Although international trade had been faltering under the world depression, China's trade remained relatively strong. The Customs Statistical Secretary, H.D. Hilliard, reflected on the arrival of unusually large numbers of foreign trade commissions as an indication of China's 'importance in the eyes of the world as a potential factor to relieve the universal trade depression'. ${ }^{15}$

Tianjin's economic vitality was a significant factor in Yan and Feng's calculations. Redirecting Tianjin's collection would have readily fulfilled their desperate need for finances. Yan and Feng's revenues were derived from taxing their provinces but this would not have been as lucrative or as regular a source as the Tianjin Customs revenue. At the least it was in Yan and Feng's interests to prevent the surplus revenue being directed into Nanjing's coffers, which could be channelled into the military campaign against their forces. From the perspective of the northern warlords it made little sense to allow Tianjin's remittance to be made available to their opposition, hence their demands to the Customs Commissioner that revenue be held in Tianjin until the outcome of the conflict.

Following a series of threats and failed negotiations, the Service was clearly forewarned that a takeover of the Tianjin Customs was looming. Maze discussed the possible seizure as early as May and conceded that, while Yan's arguments for retaining the additional revenue may have had certain logic, he was certain that Nanjing would not want to compromise. ${ }^{16}$ Maze also perceived great danger in the Service being drawn into a principal role with regard to policy. He reflected: 'I have instructed Hayley Bell (now Commissioner in Tianjin) in this sense, and have cautioned him to maintain friendly contact with Marshal Yan's representatives at all costs, and to advise non-interference ....' ${ }^{17}$ Despite these expressions of concern there was little action taken aside from Bell's appointment to this potentially delicate post. In addition Lampson described the Tianjin situation as 'peaceful' and commented that not even Bell was the 'least little bit agitated' with regard to the potential threat. ${ }^{18}$ Such steadiness in the face of the looming threat is not too surprising. Bell had been sent to Guangzhou during the boycott in 1925-6 and had taken a hard line there. The inertia by the Customs would suggest the level of confidence the Service held in its integrity - the belief that it would remain unaffected despite the warlords' threats.

To assist their takeover Yan and Feng enlisted the services of Bertram Lenox Simpson (who enjoyed some notoriety within treaty port China through his writing under the pseudonym of Putnam Weale). This was not Simpson's first dalliance into China's political affairs. The British consuls and the Western 'establishment' in China regarded him with mistrust because of his intrigues. Lampson was visited by Simpson on 13 May and took this opportunity to urge him to remove himself from this intrigue. Simpson declined, responding that it would appear he had been bribed if he suddenly acted upon Lampson's advice without consulting Yan. ${ }^{19}$ 
Needless to say, Simpson's later actions reveal he had no intention of leaving the situation. The British Foreign Office reaction appeared initially supportive of Yan and Feng's claims. But they were disturbed by Simpson's involvement in this political rivalry. Lampson commented:

It is puzzling to know what the wisest course is. Moreover, on the merits of the case, in my opinion Yen has shown more reasonable attitude than Nanking over this question, nor do I think Bell has shown any special tact. On the other hand, it is most undesirable that a British subject should thus thrust himself or be thrust into the forefront of this affair, especially a man of the type of Simpson. ${ }^{20}$

In this extract the impression is given that if a Briton had not been involved then sympathies would have rested with Yan and Feng. Simpson's involvement was seen as one of the worst possible situations for the Foreign Office.

To assist him during his takeover of the Customs house, Simpson rallied the support of a friend, L.C. Arlington, a former Postal Commissioner. Arlington accompanied Simpson and a delegation of Chinese community representatives that included the Mayor, the Salt Commissioner, the Chiefs of Police and Detectives Department to claim the Customs. Goh Jingyou, the Superintendent of Customs, informed Bell that Simpson would be replacing him. Arlington relates:

Hardly had Mr. Simpson begun his conversation with Colonel Bell than all of the officials withdrew, leaving only Simpson and myself to conduct the conversation, which was not of a very pleasant kind. I saw at once that the Chinese officials, as usual, left the fighting the dirty work - to the foreigner! ${ }^{21}$

Bell had been given prior warning of the seizure. When he discovered the phone lines were cut, Bell took a letter from his desk that he had penned in preparation. ${ }^{22}$ From this account one must question whether Simpson deserved the 'two-gun adventurer' label ascribed to him by Song Ziwen. ${ }^{23}$

In the following days Maze responded by shutting down the Tianjin Customs and declaring Tianjin a dead port. The bulk of shipping was redirected to other ports. This left the consuls responsible for the clearances of their nationals' cargoes. Bell was removed from the tense situation in Tianjin and was sent on leave to the coastal resort area of Beidaihe. ${ }^{24}$ Grierson, formerly Deputy Commissioner at Tianjin, replaced Bell in subsequent negotiations. The events in Tianjin were the focus of the NCDN cartoonist's wit (see Figures 6.1 and 6.2) ${ }^{25}$ The paper featured two cartoons on the incident. In the first cartoon 'A Domestic Question' the Beijing and Nanjing forces, represented as a soldier and a young woman respectively, are depicted fighting over a bucket of milk (customs revenue). In the second cartoon 'Heads or Haunches', however, it is Westerners who are depicted 


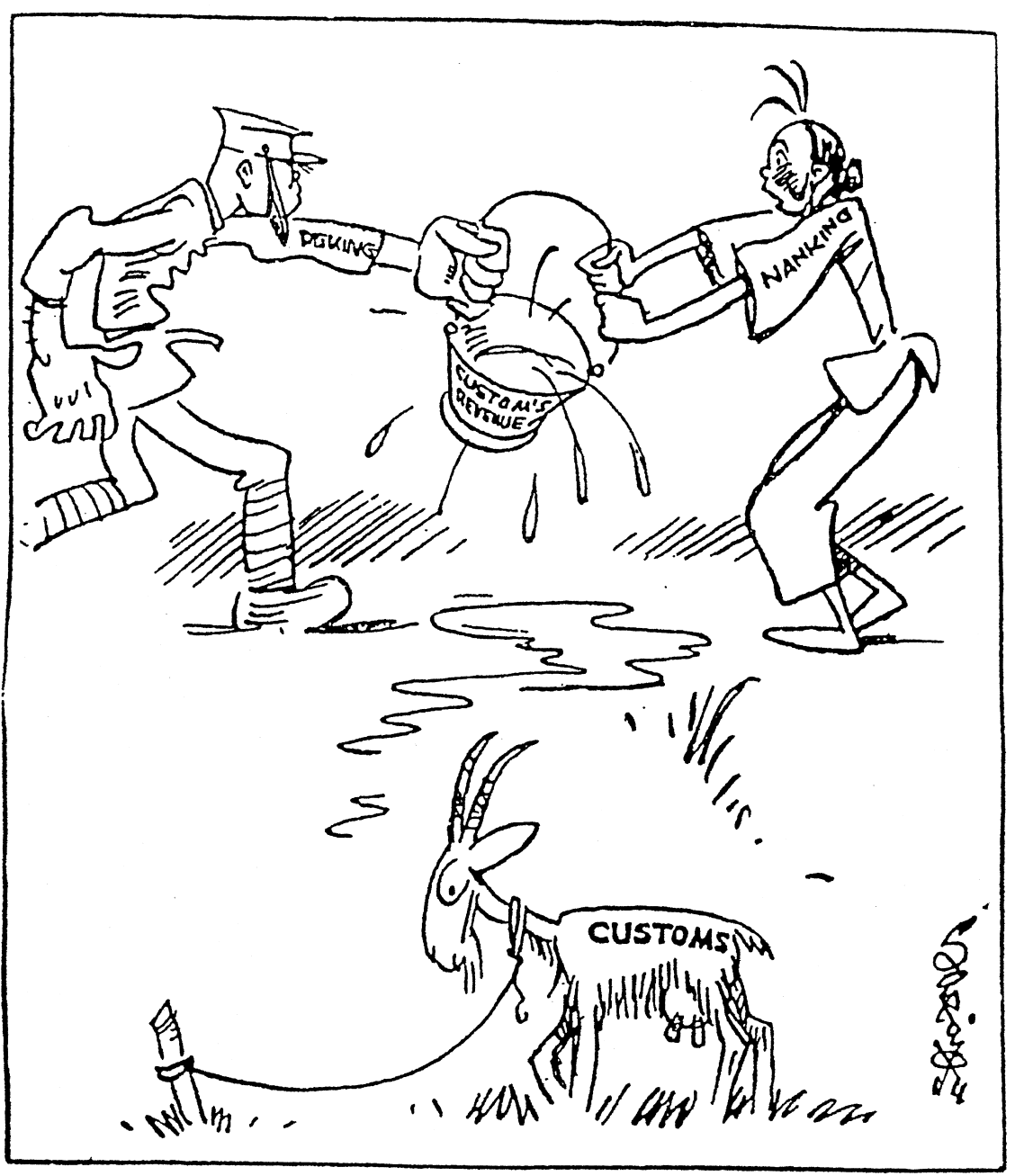

A DOMESTIC QUESTION-What it is No Use.Crying Over.

Figure 6.1 Sapajou, 'A Domestic Question - What it is no use crying over' (North-China Daily News, 18 June 1930)

tearing the hapless CMCS goat apart. Simpson was depicted as holding the head but not the substance.

Simpson defied the closing of the Customs house and reopened the establishment. In a desperate bid to retain staff, he reportedly threatened to shoot any Chinese employees who did not remain to work under his new Customs domain. When approached by Tianjin's British consul, Simpson claimed his comments had been wilfully misconstrued, but this did not 


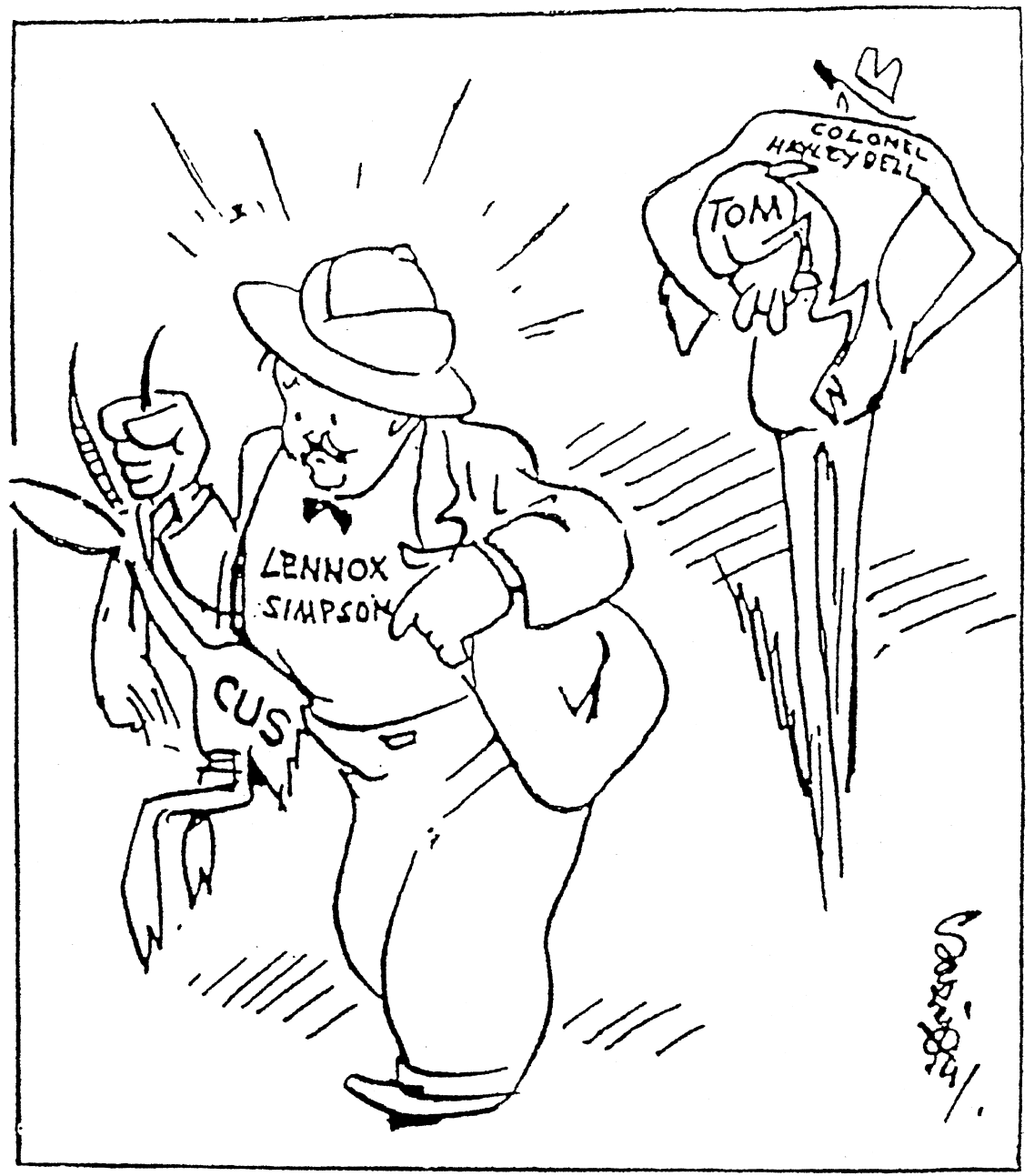

Figure 6.2 Sapajou, 'Heads or Haunches? The shadow and the substance' (North-China Daily News, 23 June 1930)

ease the consuls' fears. ${ }^{26}$ Foreign staff were recruited from rather dubious quarters to fill indoor positions. Maze commented that Simpson's regime in Tianjin was growing larger and stronger, '[his] staff include ... many ex-Customs foreign employees dismissed for dishonesty or discharged for incompetence!'. ${ }^{27}$ Regardless of the unscrupulous appearance of the de facto establishment, it not only appeared to function well but also enjoyed popularity among elements of the trading community.

The takeover of the Customs house was an indicator that Yan and Feng's 'war of words' had ended and that they had resorted to military action 
against the GMD. This escalation intensified the urgency for both the GMD and Northern Coalition to force Zhang Xueliang out of his neutrality and to take sides in the dispute. The perception shared by the warlords and the GMD, that Zhang's support would be crucial to their action, is borne out in an American consular report:

It is anticipated however, that when he considers the proper moment has arrived, the 'Young General' will offer to mediate, and perhaps use the threat of employment of his military and naval forces to require acceptance of the offer. It is generally conceded that the adherence of the Mukden faction to either of the two contending sides would conclusively determine the issue of the present civil war. ${ }^{28}$

American consular reports from Tianjin confirm that tensions between the two contending factions had been growing steadily worse in the months prior to the Customs seizure. ${ }^{29}$ For this reason there was speculation in the consular ranks that there would be the outbreak of civil war.

\section{Tianjin's de facto Customs establishment}

I realise that there may be - and probably are - political reasons against intervention. But between active intervention against, and tacit recognition of, Simpson's improvised Customs there is a wide gap!

F.W. Maze, reflecting on the policy of the diplomatic body towards events in Tianjin ${ }^{30}$

The attack on the Tianjin Customs revealed ambivalence in the treaty powers' reaction to both the Nanjing Government and to the northern warlords. This was due, in part, to the legacy of a Customs succession crisis that had shaken the CMCS in 1928-9. The British consular perception of this turn of events is vitally significant as it directly influenced official reaction to the seizure at Tianjin. To illustrate this point it is pertinent to quote at length an extract from Lampson's diary - it exemplifies just how the Minister was approaching the situation. Lampson dined with Maze and others and in the course of this function:

Maze told me the latest developments from his angle at Tientsin. It is really rather amusing. In the old days the I-G. of Customs enjoyed a quasi independent status; he was the servant of no party, but regarded himself as responsible solely to the Chinese people. Consequently, up to a point, he succeeded in keeping out of the arena of domestic politics. All this went by the board when the Government at home threw in their hand over Aglen's successor, e.g. all the fuss and bustle about Edwardes and Maze of about two years ago. Since then the position has radically altered, and Maze is definitely the servant - 
and nothing but the servant - of the Nanking Government. He merely carries out their orders and has little influence on questions of policy. ${ }^{31}$ [emphasis added]

For Lampson the Customs no longer held the value it once did for British interests in China and therefore the events in Tianjin were simply 'amusing'. Moreover there is almost a sense of glee evident in Lampson's entry, particularly as Maze was encountering such difficulties. Later in this diary entry he describes Maze's position vis-à-vis the GMD as 'pretty well inevitable' and muses that should the Service break apart there would be great temptation to tell the Foreign Office 'I told you so'. ${ }^{32}$ When confronted with the actual seizure of the Customs he commented, "[the] quasi-independent status of Customs fell with Edwardes'.$^{33}$ The Western press had continually reflected this perception that the Customs was now a Chinese-dominated institution in comments about Maze and in some ways, then, the events at Tianjin were seen as simply fulfilling predictions made by Lampson and others that the CMCS was doomed to collapse under Maze. ${ }^{34}$

From initial readings it is significant that Simpson was involved in this affair, as it appears that Yan and Feng had not desired a takeover of the Customs by a Chinese. The possible reasoning for this is fourfold: first, at the start of his China career, Simpson had served five years in the Customs Service and therefore had some knowledge of Customs procedure; second, a Westerner had the protection of extraterritoriality to cover their involvement; third, Feng and Yan, while prepared to seize the Tianjin customs, were not prepared to completely antagonize the foreign powers by appointing a Chinese as Commissioner; and, fourth, there is the possibility that Yan and Feng believed a Westerner would be more capable of running this foreign-styled customs house. At the least, a foreigner would be more difficult to remove.

The attack against the Customs in June 1930 left the British in a dilemma. Action such as the assembling of a naval force was no longer a feasible option for defending foreign interests. ${ }^{35}$ British and Japanese traders stood to be most affected by any disruption of the Customs in Tianjin and, therefore, the British and Japanese representatives were most active in seeking to bring about some sort of compromise between the northern allies and Nanjing. ${ }^{36}$ After much discussion the diplomatic body agreed to send letters of protest to both the north and south, calculated to ensure the foreign powers could not be seen as taking sides. ${ }^{37}$ This is significant as it indicates that the powers were anticipating that Feng and Yan might succeed. Therefore they wanted to have a reasonable relationship with them. Another consideration was the actual location of the Customs house, which was situated within the French concession. This was a concern as it restricted the powers from simply taking action. Regardless of this the Americans chose to recognize Simpson as the de facto head of 


\section{A Service in decline}

the Customs and allowed American merchants to resume trade. For the British, the location of the Customs house in itself posed diplomatic problems should the British have decided to defend the Tianjin Customs. ${ }^{38}$ The French believed they should only intervene if there was a disturbance of the peace. As Bell had left the Customs house without physical conflict they declined to act. ${ }^{39}$

Within a short period of time, Simpson's Customs house was accepted by all as a de facto establishment. Trade resumed a semblance of normality. Maze believed that such recognition of Simpson's Customs house had contradicted the foreign powers' own assertion that they would not intervene: 'I fully appreciate the delicacy of the situation and the desire of the Powers to "wait and see," and not interfere in this domestic squabble, but by transacting Customs business with Simpson they have in fact interfered. ' ${ }^{40}$ It was this tacit recognition that Maze described as 'heartening' for Simpson but as simultaneously creating a frustrating and 'lonely' atmosphere in which he was left campaigning for the Customs. ${ }^{41}$ From the tone of such comments, there is a sense of Maze's concern that no one shared his fears for the precedents being set by events in Tianjin.

In response to the seizure The Times criticized the Foreign Office's inaction when the Customs was seized, as they had 'let this valuable and formerly quasi-international institution become the shuttlecock of Chinese politics' ${ }^{42}$ This observation is significant in that it describes the Customs as formerly an international service. Certainly the Customs Service still retained foreign employees, and Maze wrote of the Customs as 'an unofficial outpost of Empire in view of the varied British interests still centred on it' ${ }^{43}$ This indicates a clash of perceptions of the role of the Customs Service. It is difficult to believe, though, that only the foreign staff in the Customs continued to perceive the Service as an avenue for protecting and advancing Western interests in China.

The actual takeover of the Customs house and creation of a de facto establishment did not cause undue concern for the foreign powers. Indeed all agreed that their nationals in Tianjin should deal with whatever regime that succeeded in functioning. ${ }^{44}$ Moreover, the response to Yan's claim tended to be viewed in a sympathetic light. Lampson wrote of Yan as having behaved with 'considerable patience and restraint ${ }^{\text {' }}$ ' in contrast with the Nanjing Government, which had shown itself to be difficult in negotiations. ${ }^{46}$ The involvement of Lenox Simpson continued to be a problem, described by Lampson as giving 'a bad impression from the outset' ${ }^{47}$ Indeed directly after the takeover of the Customs, Nanjing lodged a protest to the British Government calling for Simpson's deportation. ${ }^{48}$

The fracas surrounding the Tianjin Customs and Simpson's de facto establishment exacerbated tensions between Maze and Lampson. Even at the earliest times in this crisis, Maze wrote of his frustration at being left to handle everything alone. ${ }^{49}$ Furthermore he referred to Lampson as having shown 'comparative indifference' to the fate of the Service. ${ }^{50}$ 
He believed that Britain's general policy in China was appropriate and should not be altered for the sake of the CMCS but maintained that the legation had not been 'helpful' or encouraging. ${ }^{51}$ Maze detailed that he and Lampson never communicated as regards the events in Tianjin, ${ }^{52}$ this in itself an indicator of an uneasy relationship between the two. But more importantly this reflected a division between the Customs Service and the British Foreign Office that had never been so pronounced in Aglen's era. Notably, Maze was not completely alone in his frustration at Lampson's inaction; on more than one occasion Maze wrote to colleagues and confidants that both he and the Nationalists were disgruntled with Lampson's lack of responsiveness. ${ }^{53} \mathrm{He}$ recounted: 'Dr C.T. Wang remarked to me the other day, for example, that if Lampson had informally intervened as much to throw Simpson out, as he actively intervened in 1928 to keep Edwardes in, he (Simpson) would not have lasted five minutes. ${ }^{54}$ Such reflections directly related to Lampson's close involvement in the succession crisis, which had engulfed the Service just over a year earlier. It was Maze's ascension to the position of IG that had been the cause of much angst for Lampson, and it appeared that neither Lampson, Maze nor the Nationalists had forgotten this.

Nanjing's demands for the deportation of Simpson placed increasing pressure on Lampson. Under Chinese law Simpson would have faced severe punishment and the Nationalists wanted to see the British meting out punishment to Simpson. The British, who remained hesitant to be seen as taking sides and acting against the northern warlords, did not meet these demands. Also they were concerned that Simpson's actions might not be interpreted by the courts in such a way that he might be convicted, and they believed a non-conviction against him would be a much more damning prospect. ${ }^{55}$ A non-conviction might encourage other adventurers. Instead, discussion of revoking Simpson's extraterritoriality was entered into but this was considered an action of the last resort by the Foreign office. ${ }^{56}$

\section{Reclaiming the Customs}

The Tianjin Customs seizure came to an abrupt halt when Zhang Xueliang moved into the political arena and reclaimed Hebei, Tianjin and the rest of the province for the GMD in early October 1930. This reclaiming of the province also included the Customs house. ${ }^{57}$ The CMCS resumed control of the Customs house on 3 October. Grierson occupied the Customs house and on doing so all staff appointed by Simpson, both Chinese and foreign, were dismissed. ${ }^{58}$ This reclaiming of Tianjin and the province for Nanjing's control had far-reaching consequences. Not only had Yan and Feng been crushed, Zhang had made a decisive move into Chinese political arena in allying himself with the Nationalists. Simpson was victim to an assassination attempt, which left him fatally wounded, and Bell's service in China was brought to a prompt conclusion. The CMCS emerged intact, if rather shaken from the experience, bolstered by the Nationalists' success. 
Simpson fell victim to his machinations. He was shot by unknown assailants on 1 October and died six weeks later from inoperable wounds. ${ }^{59}$ It is difficult to ascertain whether this attack was retribution by the GMD for Simpson's involvement in the Customs seizure or a purging from within Yan's ranks, but Simpson's death appears politically motivated. His attackers were never identified and an air of mystery surrounded the whole incident. Maze put forward three possibilities for the attack on Simpson: (a) that he had threatened to blackmail Zhang Xueliang; (b) that he had offended Yan and Feng's Shanxi party by approaching Zhang when it appeared Manchuria was entering the conflict; and (c) that he might have been involved in an opium combine in Tianjin. The third suggestion was, according to Maze, not unlikely as under Simpson's regime drug running had increased. ${ }^{60}$ Maze regretted the attack: 'it is deplorable that at the eleventh hour [Simpson] has been created a sort of martyr by a handful of Chinese miscreants'. ${ }^{61}$ Simpson was certainly a provocative figure in China but, despite his notoriety, his death unsettled Westerners in China and press reports reflect this unease. ${ }^{62}$ Many reports despaired that the foreigner in China was under such threat.

The Customs seizure also affected Commissioner Bell. The events at Tianjin marked the end of his China service. Bell was due to retire in 1931 and had wanted to extend his tenure but this was declined. Maze's assessment of Bell's management of events underwent a dramatic shift as the crisis developed. Initially he was applauded for good work in what was agreed to be a very difficult situation. Maze not only considered Bell had endured a trying situation and thanked him for this, but also depreciated the lack of Foreign Office support for Bell's actions. ${ }^{63}$ Such accolades were, however, rapidly replaced with criticisms as the actual course of events became clearer to the IG. Maze admitted that he might have given too much credit to Bell's own accounts of his work. He commented:

I consider that Bell proved inadequate, and handled the situation badly. I instructed him to maintain friendly contact with all classes of Chinese Officials, but it seems that his 'cast iron', Prussian-dragoon attitude irritated all and sundry. It is clear that Simpson bamboozled him completely, and in the end swept down upon him and mesmerized him. In other words, he (Bell) was caught napping, and Simpson, in Bell's presence, actually obtained possession of our Code and of my confidential letters and wires - a school-boy of ten could, at least, have prevented this. ${ }^{64}$

There are other criticisms of similar nature to be found throughout Maze's correspondence in the wake of the Tianjin Customs debacle and it appears that Lampson and others supported such views. ${ }^{65}$ Primarily Bell was seen to have misjudged the situation, and in doing so might have actually facilitated the ensuing difficulties with Simpson. Despite Bell's requests 
to return to Tianjin to reclaim his former post, Maze concluded that he was ill-suited to remain in China and was therefore removed to the London Office (LO) where he served his remaining year before retirement.

While Bell was seen as partly responsible for the development of events in Tianjin, Maze believed that the ultimate fault rested with Nanjing. Bell's uncompromising position exacerbated Nanjing's refusal to consider Yan and Feng's demands, the basis of which were not unreasonable. For the Customs, its adherence to the directives of Nanjing had led it to become embroiled in the struggle between the northern warlords and the GMD. The ease with which Simpson had been able to secure the Customs house and to establish his own regime must have been unnerving for the Service, which since its inception had always promoted the indispensability of its services to China. Even more disturbing to the CMCS was the fact that the foreign powers, after initial confusion, were content to deal with whatever Customs regime was in place. This was evidence of a changing perception of the CMCS and its role in Nationalist China.

\section{Compromise at Guangzhou, 1931}

Almost precisely a year after the Tianjin Customs impasse, the CMCS was faced with a similar situation, this time centred in Guangzhou. Deep-seated tensions had erupted between General Chen Jidang and Chen Mingshu, who were the leading political and military figures in the provinces of Guangdong and Guangxi. At a conference Chen Jidang denounced the leadership of Jiang. In response to these ominous pressures, Chen Mingshu, who was the civil Governor of Guangdong, fled to Hong Kong with his supporters, leaving Chen Jidang dominant in the region. The $N C D N$ described the coup as 'bloodless'. ${ }^{66}$ On 2 May Chen Jidang and his new Guangzhou regime declared themselves against Jiang's leadership by issuing a manifesto denouncing Jiang and his followers as 'enemies of the party'. Furthermore, a second denunciation followed, encouraging any who were disgruntled with Jiang's leadership to travel south. The 'Reorganizationists', a left-wing branch of the GMD that resented what they saw as Jiang's virtual dictatorship over the GMD, supported this rival faction. Wang Jingwei, head of the Reorganizationists' movement, was appointed to the new government's committee. By the 13 May the $N C D N$ reported that the Independent GMD Government of Guangzhou was contemplating embarking on a Northern Expedition but was delayed because of a lack of funds. ${ }^{67}$

By late May Maze had already discussed his concerns over the possible implications of these political developments with Song Ziwen. He commented:

We need not cross our bridges till we come to them, but if the question of a pro rata division of the Canton Revenue does arise, my view is that it would be wiser to authorize the Commissioner there to devise 
some informal modus vivendi calculated to maintain the integrity of the Customs rather that have a repetition of the unfortunate Tientsin affair! ${ }^{68}$

For Maze this division and rivalry within the GMD raised the threat of similar experiences to those that had occurred in Tianjin with the northern warlords. He wrote to Lampson with regard to the tensions emerging at Guangzhou and stressed that he had already discussed his concerns with the Nanjing authorities. ${ }^{69} \mathrm{He}$ also explained to Lampson that his advice to Nanjing was to 'bend rather than break' and in doing so to avoid a repeat of Tianjin, but there was a note of frustration in this letter as Maze questions, 'but will they accept advice?'.

As a response to their complete break from and denouncing of Nanjing, the Guangzhou Government began to examine the loyalties of the CMCS and, more importantly, the potential revenue at their disposal. In early June the Guangzhou Government demanded that Maze should travel to Guangzhou as IG of Customs. Deng Shaoyin and Wu Shangying, the Minister and Vice-Minister of Finance respectively, informed Maze that in the place of the Nanjing Government, the GMD had established a new national government at Guangzhou. They ordered Maze:

You are hereby instructed that henceforth you are to take orders from this Ministry in performance of your duties as Inspector General of the Chinese Maritime Customs. You are further instructed to immediately remove to Canton the Inspectorate General of Customs and to come to Canton at once. You are further instructed to issue orders to all Chinese Maritime Customs Houses to have all revenues remitted to this Ministry. ${ }^{70}$

Similar instructions to proceed to Guangzhou were also given to Stephenson, the Commissioner of Kowloon. ${ }^{71}$ In what can only be described as covering all possibilities, the Guangzhou authorities also offered Stephenson a post as Southern IG. Maze was extremely confident that Stephenson would refuse to play any part in splitting the Service. ${ }^{72}$

On 6 June the $N C D N$ reported on the possibility of a 'Customs Coup in Canton'. It revealed that a takeover similar to what had occurred in Tianjin a year earlier was being contemplated by the authorities in Guangzhou. The article commented: 'endeavours were being made to arrive at a satisfactory arrangement under which the integrity of the Customs will be maintained. ${ }^{73}$ Maze presented a case to the Guangzhou authorities that as Guangzhou, Shantou and other offices in the region represented 11.5 per cent of total revenue, these houses should not only contribute a proportion of the cost of the 5 per cent for indemnities but also that they should contribute towards the maintenance of domestic loans. ${ }^{74}$ His reasoning for 
this was that the Guangzhou Government would hardly want to damage national interests through any precipitate actions. Maze feared such suggestions may falter and therefore telegraphed Commissioner Braud in Guangzhou and arranged for him to hand over all but 5 per cent of the revenues under force majeure. ${ }^{75}$ While this may seem a defeat for the Customs, it was a manoeuvre that preserved the integrity of the Service as Nanjing could still maintain the staffing of the Customs houses.

By 12 June the dispute had been circumvented. The relative speed in coming to some compromise was a result of Maze's ability to negotiate terms satisfying to both governments. An agreement was reached that all revenue from the Guangzhou region, with the exception of the 5 per cent for loans and indemnities, would go to the coffers of the Independent GMD Government. This surplus was quoted by the $N C D N$ as being around two million per month. ${ }^{76}$ In an editorial on 16 June the $N C D N$ applauded this agreement, claiming it not only gave prestige to the Service but also showed that both governments had the vision to put national good above personal ambitions. The same article praised Maze for his skilful diplomacy in handling such a delicate situation. The editorial commented: '[Maze] can be assured moreover of the goodwill and gratitude of the financial, commercial and shipping communities of all nationalities, in the reinforcement of his labours. ${ }^{\prime 77}$ The $N C D N$ 's concern (shared with Maze) had been that the Nanjing Government would choose to follow a similar line to that of non-intervention in Tianjin; the situation in Guangzhou was more significant as the region represented a larger proportion of the total Customs revenue (10 per cent). The British Foreign Office also commended the compromise, describing it in terms of the Nanjing Government having learnt a lesson from the events in Tianjin. ${ }^{78}$

Despite this early success in acquiring Customs funds, the Guangzhou Government's existence was short-lived. Access to Customs revenues from Guangzhou was not a sufficient revenue source to adequately fund the Guangzhou regime. The NCDN discussed the government's imposition of gambling and opium monopolies to raise revenue. A rent tax was also implemented. ${ }^{79}$ For reasons that remain unclear, the threatened Northern Expedition of Independent GMD forces did not eventuate. On 16 September southern forces had been advancing to Hunan to challenge the Nationalists' forces but, before hostilities broke out, they were in retreat. The British Foreign Office speculated that this might have been due to secret peace talks having been carried out. Japanese aggressions in Manchuria were, however, largely credited with expediting the settlement between Nanjing and Guangzhou as both governments realized the urgency for a united government in a time of crisis. ${ }^{80}$ The Service had, through the active diplomacy employed by Maze, avoided a repeat of the Tianjin incident. In doing so it had also benefited from a tacit agreement by factions of the GMD that the Service's integrity was vital to the future of nationalist China. 


\section{A Service in decline}

\section{The loss of Customs houses in the north-east}

Poor China! What next will happen to her. I hope that out of all the turmoil some lasting good for her may come and that she will learn her lesson but it is difficult to see any happy sign yet. The old Customs is still her best friend - in fair weather or foul.

W.O. Law $^{81}$

Maze's leadership had weathered some turbulent years but there was little respite in store for the CMCS. In 1932 the Customs faced serious challenges to its functioning and the seizure of Customs houses in Manchuria signalled the severing of the north-east from the Service. The lament from Law for 'Poor China' was quite apt. However, in retrospect, lamenting the CMCS might have been even more appropriate, as by the middle of 1932 at the instigation of the Manzhuguo authorities, the north-eastern Customs houses were seized. In the lead up to these seizures, the 'best friend' of China was first abandoned by the GMD, whose leaders showed their willingness to sacrifice the Service to ensure their own political survival. Second, it was betrayed by the Japanese Guandongzhou (Kwantung) leased-territory authorities, who gave their infant state predominance over the fate of the Service. And, third, it was betrayed by the foreign powers, who were hesitant to go any further than to make unofficial enquiries on the behalf of the Customs.

The aggressive actions of the Guandong Army in the north-eastern provinces of China in 1931-2, culminating in the declaration of independence of Manzhuguo (17 February 1932), had far-reaching ramifications for not only Sino-Japanese ties but also international relations. ${ }^{82}$ The effects of these ambitions on Customs outposts in the north-east have not received detailed research. Arguably the creation of Manzhuguo resulted in the largest threat to the integrity of the Service in the course of its 70-odd years of existence. Rumours of the intended takeover of the north-eastern Customs houses by the Manzhuguo authorities appear to have been circulating around the time of the creation of the new state. For Maze the tensions that were mounting in the north were irrevocably tied to the general political tensions in Sino-Japanese affairs and therefore his challenge was to balance such a delicate situation without endangering the integrity of the Service in the process. As the Service foundered under the growing threat of loss of Customs houses, the foreign powers endeavoured to assist the Service, but only on an unofficial basis and in deference to the tensions still surrounding the north-east. The Nanjing Government, after deciding not to allow any negotiation with the new Manzhuguo authorities, similarly tied Maze's hands from any attempts at reaching a compromise that would save the Service from imminent danger. The creation of Manzhuguo and pressures to join the new regime polarized staff in the north-east, with Japanese staff resigning and declaring their loyalty to the new Manzhuguo authorities. 
Deep-rooted tensions between the reactionary Guandong forces and the Chinese precipitated a crisis in 1931 following the suspicious circumstances surrounding the death of army captain Nakamura ${ }^{83}$ and later an explosion along the South Manchurian Railway Company's (SMR) Shenyang (Mukden) line. This event heralded the pretext for the Japanese occupation of key cities in the north-eastern provinces on 18 September 1931. This action was clearly premeditated on the part of the Guandong forces, and it is commonly held by researchers in this field that the military engineered the actual railway explosion as a catalyst for their plans. American journalist Abend (a China correspondent for the New York Times) recounted being tipped off by a Japanese official in Shanghai that military action was imminent in the Manchurian region. Abend was concerned, wondering whether the US and Britain would stand by and 'permit a gigantic territorial theft of this kind' ${ }^{84}$ His subsequent reports to consular officials on the intended actions of the Guandong Army, however, fell on deaf ears. He later reflected on Japanese actions in September 1931 and beyond to action in 1937 with a grudging admiration:

Conquest can never be a pretty nor a clean job, but certainly the Japanese managed the conquest of Manchuria in a much better fashion than they did the conquest of coastal China begun in 1937. In Manchuria, of course, there was slaughter, there was intimidation of the civilian population, there was some ruthless confiscation of property, and there were economic injustices. These things seemed inseparable from militarism in its active phases. ${ }^{85}$

Press reports at this time often betrayed a sense of empathy with the longsuffering Japanese finally provoked into action by the unpredictable Chinese and yet, at the same time dismay, at the course the Guandong Army opted to take. ${ }^{86}$ World attention was, however, drawn away from this centre when on the pretext of Chinese provocation the Japanese launched an attack on Zhabei, the Chinese city area of Shanghai. Japanese forces were repelled by the valiant efforts of limited Chinese forces (19th Route Army), much to the grudging admiration of the foreign onlookers in the treaty port. In the course of this conflict, Maze was active in his protection of Japanese staff in the Inspectorate (located in the foreign concession). The NCDN reported that he had received a special message of gratitude from the Japanese Government to this effect. ${ }^{87}$

The seizure of the Customs houses in the north-east that occurred in mid-1932 was a great blow to the Service and also had significance in revealing Japanese aspirations for the region. Despite Japanese protestations that Manzhuguo was a self-declared independent region, it became apparent to all onlookers that the state was a facade for Japanese imperialist ambition in northern China. When faced with the prospects of a takeover from the Manzhuguo authorities, Customs Commissioners generally (and 
with the benefit of hindsight we may also reflect, rather naively) appealed to the Guandongzhou authorities for assistance but found that none was forthcoming.

Customs reports for 1931-7 are incomplete and those that are available tend to refrain from making direct comment on the political situation embroiling Sino-Japanese tensions. Customs documents detail the Commissioners' experiences at each of the Customs houses that were threatened and eventually seized by the Manzhuguo authorities. These document the deliberate intimidation of foreign and Chinese staff and persistent attempts to bribe employees to change allegiances. Customs houses subjected to these pressures, and ultimately to a takeover, included Harbin, Shenyang, Longjing (Lungchingtsun), Huichun, Niuzhuang, Andong, Aihui and Dalian. Of these, the seizure at Dalian was the most significant, seeing that it was created as a treaty port under Japanese treaty with China (1907) and therefore no interference had been anticipated. Any action against the Dalian Customs, it was reasoned, would need to have tacit Japanese approval before anything could take place. As Dalian became a catalyst for Manzhuguo to move against Customs houses throughout the north-east the following sections include a detailed study of the Dalian Customs' experience.

Revenue from the north-eastern provinces represented a significant percentage of the total Customs revenue. It was a substantial portion of funds, therefore, that was under threat should the Manzhuguo authorities move into action. More so than just the funds, the whole basis of the Service was facing a direct challenge. Manchurian ports represented around 12 to 18 per cent of Customs revenue. ${ }^{88}$ Of this proportion of revenue, Dalian represented almost half of the north-eastern remittances.

In the lead up to the creation of the state of Manzhuguo, there was a certain amount of unease on the part of Maze and those interested in the future of the CMCS but nothing tangible to raise serious concerns. The newly independent state of Manzhuguo (inaugurated in February 1932) was commonly recognized by the Chinese and foreigners in China as a puppet regime. The creation of Manzhuguo and the demands of a newly established state for revenue provided the impetus for a significant challenge to the future of the Service. In March Maze discussed a report received from the Harbin Commissioner, H. Prettejohn, who had heard on 'good authority' that the new state was in urgent need of funds and that the Japanese were preparing to take over control of all Customs houses in Manchuria. What Maze could not discern from this report was the estimated time-frame for any such action. ${ }^{89}$ Any such occurrence was to be avoided, if at all possible, and Maze began presenting such suggestions to the Nanjing Government.

From 11 to 14 March the Nanjing Government, at Maze's request to allow Customs representatives to make contact with the new Manzhuguo authorities, sanctioned an unofficial representation. Commissioner at Dalian 
Fukumoto, and Chinese Secretary, Ding (full name Ting Kwei-tang), were authorized to approach the Manzhuguo authorities in the new capital of Changchun to put forward the case of maintaining the integrity of the Service. Fukumoto and Ding were able to speak at length on an unofficial basis with representatives from Manzhuguo to discern the new state's plans for the Service. They did so with the intention of moderating these views. ${ }^{90}$ These talks, as detailed by Fukumoto, met with a degree of success in having informally put forward the CMCS' view for consideration. The talks were also received with a certain degree of sympathy for the case of maintaining the Service.

Fukumoto reported to Maze that he spoke with the Japanese Consuls General from Longjing and Jilin. ${ }^{11}$ He also met with an ex-Customs employee who was the Chief Secretary of a large chamber of commerce in Japan and acting as adviser to the new government. Fukumoto commented: 'I found that the new government was busy with preparations for taking over all Manchurian Customs houses and for opening a new office at Shanghaikuan, and that they would remit a certain sum for foreign loan obligation. ${ }^{92} \mathrm{He}$ immediately set about attempting to convert these and other officials to his way of thinking. A key element of Fukumoto's response to these intentions was to stress the detrimental effects for Japan. He presented that it was unwise for the Japanese to become involved in political complications and of damaging future trade agreements. Thus he pushed for negotiations with the Chinese authorities. He was pleased to learn that such comments had not gone unheeded; and reported to Maze that he had met with a measure of success, but was ultimately to be disappointed that his suggestions were only adopted in part. ${ }^{93}$ Ding's report of negotiations lacked the detail of Fukumoto's but gave significant reflection on the perceived attitude of the Manzhuguo authorities. Ding commented on their attitude towards the CMCS as being 'polite, sincere and friendly'. ${ }^{94}$ Earlier in the same message, however, he reported the situation as 'critical' and expressed fears that any delay in reaching some settlement would cause disaster. In his report Ding attributed the delaying of the Manzhuguo threat to the Customs Service to the strenuous efforts made by Fukumoto. ${ }^{95}$ There was recognition in the British Foreign Office reports of Fukumoto's outstanding efforts to defend the Service. In particular the Foreign Office praised Fukumoto's determination in the face of what was seen as considerable personal danger. ${ }^{96}$

Maze was not idle while Fukumoto and Ding approached the Manzhuguo authorities. On 17 and 19 March he outlined his views on the situation in confidential letters to the Minister of Finance. ${ }^{97}$ In these letters he proposed that the Manzhuguo authorities should liquidate a pro rata share of the indemnities and loans secured on the Customs and in doing so retain the balance. This was to be done on the understanding the Inspectorate system remained undisturbed. This compromise would be maintained pending and resultant on settlement of the 'final question', that of the Sino-Japanese 


\section{8}

question. Maze believed that such an arrangement loosely conformed to that which had been enacted in Guangzhou in 1931. To his frustration, however, Song Ziwen transmitted his confidential letters to the Government's executive Yuan. As a result Maze was assailed by an indignant Wang Jingwei (President of the Yuan) and others for stating that there were similarities in the Guangzhou and Manchurian situations..$^{98}$ Maze was disappointed he had been led into this predicament and this heightened his fear that he may be left responsible should any crisis erupt.

The Nanjing Government negated the possibility of negotiating directly with the Manzhuguo authorities and they declared that no agreement or understanding of any kind should be made between the Customs and the new territory. Maze was instructed accordingly that all his future actions should be carried out in the spirit of this non-recognition directive.${ }^{99}$ The creation of Manzhuguo was an intensely political situation and it was therefore a risk for Chinese politicians to be seen in any way condoning negotiations with this new authority. Maze expressed frustration at what he saw as the political protectionism of the Nanjing Government commenting, 'in order to save their own skins, the existing powers that be in Nanking are quite prepared, it seems, to sacrifice the Customs integrity in Manchuria' ${ }^{100}$ It was in Maze's interests to attempt to keep the Service clear of the political side of events but obviously this was almost impossible, the Service being so intricately bound to the Nationalist Government.

As events were so closely tied to the political situation in China any foreign defence of the CMCS was carried out in unofficial communications. Britain, in particular, was reluctant to be drawn directly into a situation that the League of Nations Commission would soon investigate. Maze wrote of the invaluable support Lampson had given him and recorded Lampson offering, 'I should be glad to do anything I could to strengthen your hand'. ${ }^{101}$ Despite these helpful overtures, the British Minister was reluctant to take official action. Indeed from the reading of Foreign Office correspondence it appears Lampson was torn, not as to whether to support the Customs or not, but as to the channels of support that would be appropriate. He acknowledged that the integrity of the Service had 'long been a cardinal point of British policy in China', ${ }^{102}$ and while not wanting to abandon the Customs he didn't feel that such considerations were weighty enough to demand protests be made to the new Manzhuguo authorities, which Britain had not offically recognized. ${ }^{103}$ This hesitancy was echoed throughout the British Government. The LO's NRS, Walsham, spoke with Sir Victor Wellesley and reported, 'it struck me that the general attitude of the British Government is one of marking time and that they wish to leave China to manage her own affairs and not to move themselves unless absolutely compelled to'. ${ }^{104}$ Even as early as March, therefore, Maze was aware of the potential problems the Service would encounter should the threats of takeover eventuate. 
Maze had attempted to put forth his views for possible compromises that would relieve the situation, but once Nanjing's policy was made known (through meeting with Song), these overtures were never raised again. His concern over the future of Customs houses within the new state is obvious:

We still sail in troubled waters and the Manchurian affair has created a rather dangerous situation for us. I believe that if I were given a free hand I could effect a settlement which would be satisfactory to both parties, without prejudicing the major question - that is, the occupations of Manchuria - but the Nanking Government have various political reasons for not allowing my advice and, of course, as Inspector General it is for me to execute, and not formulate, the Government's policy. ${ }^{105}$

The phrase that 'history was repeating itself' appears in the Maze Papers relating to the Manzhuguo threats against the Service. ${ }^{106}$ Maze clearly perceived that the events in Tianjin in June 1930 and in Guangzhou in 1931 had certain parallels with events in the north-east. ${ }^{107}$ This is not to say that he did not recognize the essential difference between previous seizures of the Customs and the current threat from Manzhuguo. Rather, Maze recognized that Manzhuguo represented an external and potentially much more damaging challenge to the unity of the Service. A commonality in these affairs was, to his estimation, GMD reluctance to allow him to enter negotiations that he believed may have saved the Service from losing the Customs houses completely. Moreover, Maze expressed the view that the CMCS was being sacrificed by the GMD. ${ }^{108}$

As with much of Maze's leadership, pragmatism was a key. When greeted with the potential threats by Manzhuguo authorities, Maze's philosophy was that of compromise. He stressed the need to give way to minor points for the sake of saving the larger whole:

The chief consideration is to maintain the integrity of the Customs Service in the General interest of all - including Japan. This being understood, we ought to endeavour to avoid raising major questions; give way, if necessary, in the case of minor questions; and try and localise the issue as much as possible. If the Manchukuo Authorities seize the Northern Revenue, let it be seized from the Revenuecollecting Bank (the Bank of China) and not from Commissioners of Customs; and should such an irregularity occur, we here, on our side, will deal with the bank and leave it to handle the matter with those concerned in the north: that it to say, we ought to strive to keep the question of administrative control in the background, and it will probably be deemed convenient by everyone not to disturb the existing Inspectorate system at present and leave us to continue to exercise control over Staff, collection of revenue, and harbours. ${ }^{109}$ 
From this passage it is apparent that Maze believed that, by removing the focus of tension from the Service to the banks, it could remain unaffected. This was a superficial view, however, as regardless of where the revenue was seized it would still affect the CMCS. The key to his reasoning appears to be the presumption that the Manzhuguo authorities would want to avoid the inconvenience to their interests that would accompany any disruption of the Service.

\section{Dalian and the Fukumoto affair}

In June tensions surrounding the fate of the CMCS outposts in Manchuria, which had simmered since the creation of Manzhuguo, reached their climax. Within the space of only a few days the new authorities moved into action and seized the majority of Customs houses in the north-east, starting with Dalian. Throughout June 1932 the NCDN focused on the situation surrounding the CMCS, publishing reports of a plan to appoint a Japanese IG. ${ }^{110}$ An editorial early in the month, entitled 'Japan Adrift', discussed the gravity of the situation in Manchuria and saw the fate of the Service as a secondary question to that of the Japanese occupation, which the Lytton Commission would be addressing. The article stated:

The seizure of the revenue may, of itself, be comparatively unimportant, grave though that step obviously is. The real gravity of the crisis lies in the attack on the integrity of the Customs as the one stable service in China and a most important factor in the preservation of the often precarious relations subsisting between China and the Foreign Powers. ${ }^{111}$

The editorial demanded that the Customs should be 'swiftly protected' not merely for the revenue but because of its significance to the future of Chinese political and economic development. The premeditated quality of Manzhuguo's actions by late June, however, appeared to have stunned the foreign powers. Even more disconcerting was the overarching Japanese support for these takeovers.

The situation escalated in Dalian when from 7 June Commissioner Fukumoto, under significant pressure, failed to remit revenue to the Shanghai Inspectorate. When sent a telegram by Maze questioning why this was the case, Fukumoto responded that he had hesitated to send any remittances for fear of precipitating a crisis. In a telegram on 15 June, Maze made it clear that Fukumoto did not have the authority to discontinue remittances. Again Fukumoto, after explaining that he had not discontinued but rather suspended payment of revenue, described the outcome of a meeting with Guandong officials (not Manzhuguo officials, which reveals the close allegiance between the two authorities in Dalian) and urged that 
compromise must be met to avoid 'imminent rupture and taking of drastic action by Manchukuo'. ${ }^{112}$ The Yokohama Specie Bank, which was acting as the Customs bank in Dalian, refused to hand over remittances and Fukumoto empathized with what he described as their fear of becoming involved in political disputes. Events taking shape at Dalian had rapidly spread beyond that of a Customs issue.

Fukumoto was warned by Kawai (Chief of Section for Foreign Affairs of the Guandongzhou Government) that his determination to remit was 'highly provocative' and that should he proceed to do so, Japanese interests in Guandong leased territory might be affected. In addition Kawai asserted that the Manzhuguo Government's claims to Manchurian Customs revenues were well founded. This was greeted with incredulity by Maze. ${ }^{113}$ In accordance with this advice Fukumoto was urged to postpone any action and he appealed to Maze, 'in the present situation it is practically impossible for me to ignore the strong wish expressed by Leased Territory Authorities' ${ }^{114}$ Maze condemned this passive stance and ordered Fukumoto to execute instructions. Fukumoto's unwillingness to act on the instructions became obvious as he telegraphed:

A passive attitude is the only one possible for me at the present moment. I am myself convinced and also have been warned by responsible Japanese Authorities that an open rupture between Dairen Customs and Manchukuo would be destructive to Japanese interests. That I, a Japanese, should be the instrument to bring about such a rupture is intolerable and against my conscience. ${ }^{115}$

Despite such blatant insubordination Maze was hesitant to take any drastic action until he had consulted with Song on the matter. The opportunity to discuss this impasse was delayed as Song was travelling from Beiping (Beijing) at the time. On 23 June Fukumoto was instructed to stand aside, to place the Deputy Commissioner Hakamura in charge and to proceed to Shanghai. ${ }^{116}$

Fukumoto's actions had administrative and political significance. When asked by Song for his opinion, Maze responded that dismissal was the only punishment for Fukumoto's insubordination but that he realized the consequences of this would extend further than simply removing him from the Service. He reflected, 'from a political standpoint it might be desirable to go slow; that he [Song] must consider that dismissal would make Fukumoto a martyr, a patriot and a hero, etc.' ${ }^{117}$ Despite these reservations Fukumoto was dismissed on 24 June. The $N C D N$ devoted its editorial to this dramatic turn of events and expressed sympathy for Fukumoto. The paper acknowledged that he had served the Service loyally in the past and had no doubt endured great personal pressures in the lead up to his dismissal. But the paper agreed that the Chinese Government 
was fully justified in taking action against this unprecedented behaviour. ${ }^{118}$ The editorial examined these events as further evidence of Japanese complicity in the Manzhuguo state:

For days past Tokyo had refused to admit that the assault on the Dairen Customs was contemplated. The technique has been the regular stockin-trade of Japanese diplomacy ever since September last. It has lost for Japan incalculable sympathy the world over. ${ }^{119}$

This action in Dalian had been largely unforeseen owing to its status as a leased territory, but this takeover had created a precedent. As Maze outlined in his report on these events, seeing that Dalian was within Guandongzhou leased territory it had been assumed that interference with the Customs there would not be tolerated. ${ }^{120}$ The impasse with Fukumoto proved the folly of this view.

Ingram of the British Foreign Office regarded Fukumoto's dismissal as 'deplorable'. ${ }^{121}$ Under the Dalian Customs Agreement any replacement was required to be a Japanese national and, therefore, little real change could be effectively made. Furthermore such action was regarded as having 'afforded the Japanese a suitable pretext for bringing to an end once and for all the Chinese customs regime in Dairen'. ${ }^{122}$ As events transpired CMCS and GMD reaction to the impasse in Dalian did become a catalyst for seizures throughout the north-east. In response to Fukumoto's dismissal, Deputy Commissioner Hakamura resigned his post and by 27 June all Japanese staff at Dalian had severed their ties with the Service. It is arguable that Fukumoto's dismissal prompted the Manzhuguo authorities into action and by 8 July all Customs houses had been seized. The northeast was effectively torn away from the Service.

\section{Moves against the Customs Service (March-June 1932)}

the Japanese have now started developments which may (in fact will, unless there be a rapid restoration of the position) undermine the Chinese Maritime Service and all for which that Service stands. ... The whole affair is equivalent to robbery under arms.

North-China Daily News ${ }^{123}$

The $N C D N$ was not alone in its indignation over the actions of the Manzhuguo authorities in the north-east. Such outrage did not, however, translate into concerted action against forcible takeovers, rather the foreign powers looked on as the Customs suffered a crushing blow to its existence. As outlined previously, the Customs houses affected by Manzhuguo's ambitions for the region were in Aihui, Andong, Dalian, Harbin, Huichun, Longjing, Niuzhuang and Shenyang. Reports from the Commissioners at these posts afford a review of events leading up to their forcible removal 
from the Customs houses at the instigation of the new authorities. ${ }^{124}$ The affected areas experienced a general pattern of threats against the Customs house and intimidation of staff. In most cases by March the Customs houses encountered their banks' refusal to remit funds from the Customs account to the Shanghai Inspectorate. By the end of March, therefore, the Customs houses were in a deadlock. Regardless of their desire not to be drawn into the demands of the Manzhuguo authorities, they were thwarted by the banks' refusal to remit revenue at the requests of the Commissioners. Maze had anticipated that such action would then allow the Customs to continue to function, as the issue was then not with the Service but the banks. This, however, was not to be the case. In most instances any substantial remittances to the Inspectorate had ceased by late April to early May.

Following the dismissal of Fukumoto, Manzhuguo forces, bolstered by Japanese police and in some cases military personnel, proceeded physically to take over the Customs houses. Commissioners arrived at work to find the Customs houses under armed guard. In Harbin the Manzhuguo authorities attempted a takeover at night but were bluffed from doing so by Commissioner Prettejohn and a number of Customs employees. This thwarting of the Manzhuguo forces was short-lived as staff arrived the following morning to find the Customs house was barred shut. ${ }^{125}$ In all instances the Commissioners were placed under considerable pressure and personal danger; they were often compelled at gunpoint to relinquish files, keys to safes and official documents. At Andong and Harbin the Commissioners' residences were similarly violated, subjected to 'raids' as documents were hidden and staff sheltering there were sought out. Even as early as March Prettejohn had been approached to join the new regime and his Deputy Commissioner was also entreated with cash incentives. Staff at all other houses, including Longjing, Huichun, Niuzhuang and Shenyang, were subject to threats and often imprisonment to induce them to join the new regime. As Prettejohn commented on his staff's experiences at Harbin, '[w]hen "Manchukuo" want a man to work for them and he refuses, the usual method is to put him in prison and treat him so badly that he eventually consents to anything'. ${ }^{126}$ Despite such pressures and personal dangers, the majority of Customs staff remained loyal to the CMCS.

Armed men, accompanied by a Japanese intelligence officer, forcibly ejected Commissioner Wallas and his staff from the Longjing Customs house on 29 June. In response to this affront Maze lodged a protest with the Japanese charge d'affaires. ${ }^{127}$ In particular he questioned the grounds for Japanese involvement in such actions. This protest was largely discounted by the chargé d'affaires, who maintained that an investigation had confirmed that Japanese military authorities had not taken part in any such actions and that furthermore Wallas was satisfied with the protection accorded to him by the Japanese Consulate-General. Denial of Japanese 
involvement in Manzhuguo's actions against the CMCS was a common device but had lost much of its plausibility by this stage.

In the lead up to, and during the takeovers, a number of CMCS staff were imprisoned. Those unfortunate enough to be incarcerated were reportedly mistreated in a bid to coerce their support for the new regime. Few staff succumbed to these pressures. In Harbin Prettejohn took to harbouring staff that he considered in a position of danger and then assisting them in smuggling out of the town. ${ }^{128}$ Similarly in Niuzhuang Acting Commissioner Shaw had given instructions for any staff that could do so to try their best to escape from the port. ${ }^{129}$ In Aihui Commissioner Joly proceeded to evacuate all staff and their families that he considered to be in danger. ${ }^{130}$ Their journey by rail and vessel to Shanghai was indicative of the dangers they had faced in the north-east.

After Fukumoto's dismissal all Japanese staff severed their ties with the Customs and entreated others to do the same. After the takeovers new employees were required to work for the regime and some Chinese CMCS staff were forced to remain in the interim to keep the houses operational. At Niuzhuang they were forced to keep filling their duties while under armed guard, until replacements could be procured for the new regime. Shaw reported that these staff used passive resistance to the new regime. He detailed:

[they] performed their duties in the most perfunctionary manner possible, with the result that the staff of the 'New Customs' learned their duties in a very poor manner, and that the office work was carried out in a very confused way resulting in a large falling off of revenue and the commission by merchants of many offences which could not be detected by the ignorant and uninformed 'new staff'. ${ }^{131}$

Clearly, the new authorities encountered a stronger resistance to their new regime than they had envisaged. There were relatively few defections to the new Customs apart from those of the Japanese staff. Threats and/or cash incentives were necessary but not entirely successful in attracting staff to the new regime.

The two most prominent defections to the Manzhuguo regime were Fukumoto, the Commissioner of Dalian, and former Acting IG Edwardes. Fukumoto became the Commissioner at Dalian for the Manzhuguo authorities and was responsible for removing the existing staff from office. While the Customs houses were being seized there were approaches to Maze regarding the possibility of having Fukumoto reinstated. It was suggested to Maze that this might relieve some of the pressures being placed on the Service in the north-east. Japanese authorities were keen to draw parallels between Fukumoto and former IG Aglen. Maze, however, failed to agree with these 'similarities', seeing that Aglen was insubordinate in refusing 
to follow government orders in the interests of the Service; whereas Fukumoto's insubordination was at the 'bidding of an alien state'. ${ }^{132}$ Needless to comment Fukumoto was not reinstated.

Edwardes' defection came in 1933 but still sent shockwaves through the Service. Although Edwardes was no longer an active member of the Customs, his acceptance of an appointment as an adviser to the Manzhuguo authorities was an affront to not only the Chinese but also the entire Service (Edwardes was Aglen's appointed successor in 1927 but had become embroiled in the succession crisis that had ultimately brought Maze into the Inspector Generalship). The shifting of allegiance by someone who had been an employee of the CMCS was seen as particularly reprehensible. The Chinese Government responded to the news of the March 1933 appointment with the release of a circular condemning Edwardes' 'despicable' act:

[Edwardes'] action therefore in accepting post of adviser to the socalled Manchukuo is not only manifestly one of base ingratitude which has aroused the deep resentment of his former comrades in the Chinese Customs Service and cast a slur upon the hitherto high reputation and loyalty of the Service as a whole but is also in glaring contrast to the behaviour of the foreign staff of the Customs until recently serving in Manchuria who, though offered bribes, subjected to the greatest possible intimidation and even imprisonment, resolutely refused to give to the so-called Manchukuo the benefit of their services and remained staunchly loyal to the Chinese Government. ${ }^{133}$

In retribution for this traitorous act, the Nanjing Government cancelled all honours that had been conferred on Edwardes. ${ }^{134}$ Whether Edwardes retained his pension is somewhat unclear. Edwardes was rumoured to have received $£ 5,000$ a year from Manzhuguo while still being pensioned by the Chinese Government. Despite his 'shady' dealings, Edwardes became a confidant to Sir Warren Fisher, the Permanent Secretary of the Treasury. ${ }^{135}$ Edwardes was listed in the Manzhuguo Handbook of Information for 1933 as a Counsellor to the Department of Foreign Affairs. ${ }^{136}$ According to Maze, moreover, Edwardes' appointment as an adviser to Manzhuguo was regarded as nothing more than a joke but that naturally the Chinese authorities were angry over this betrayal. ${ }^{137}$ Edwardes' actions also brought the foreign basis of the CMCS into disrepute.

By late 1932 some of Maze's greatest fears for the Customs Service had been realized. There was no longer any question of maintaining the integrity of the Customs in Manchuria as it had been completely severed from China's Customs administration. ${ }^{138}$ The Inspectorate had once again had its hands tied by the reluctance of the GMD to enter into negotiations with Manzhuguo. Further to this, the foreign powers were unwilling to make 
anything more than unofficial overtures to the Japanese on this issue. Despite recognition that foreign interests in China were endangered by the actions of the new authorities in seizing the Customs houses, the powers failed to respond. For the CMCS an era had passed - that of a unified Service enjoying the support of the foreign powers in China, and in its place dawned one that would be marked by a bitter struggle for continued survival. 


\section{7 'Steadfast and fearlessly persistent' \\ The CMCS in the face of war, 1937-45}

Though much which the institution represent belongs to the buried past, it will deserve to be remembered as a model of disinterested efficiency and of practical international service.

The Times, on the CMCS, 1 June 1943

As traced in preceding chapters, the influence and coherence of British interests in the Service had been already been significantly challenged by the early 1930s. A much more direct threat came with the culmination of Japanese ambitions in China and the outbreak of the Sino-Japanese War in 1937. This chapter examines the fate of the Service in these later years leading up to its removal from the mainland. For the CMCS the outbreak of war initiated a struggle for survival in the face of substantial challenges. Through compromise and determination, the Service was able to remain intact, albeit operating under adverse conditions. Moreover the difficulties for the CMCS ran deeper as the Nationalists sought to reduce the independence of the foreign inspectorate, much as it had done to the Salt Inspectorate. Consequently, in 1943 Maze submitted his resignation, thus ending the era of British leadership of the Service. The Service continued to function, in spite of great difficulties, until its removal to Formosa (Taiwan) in 1949. Some Customs staff opted to remain in China to work under the Communist party. The end of the Republic marked the end of the CMCS as a Chinese institution and its role within treaty port China.

This chapter provides an overview of key events and themes relating to the final decades of the CMCS. The year 1937 will be examined in some detail as a way of highlighting the primary features of the wartime experiences of the CMCS. Difficulty in remaining a national Service, operating in occupied China and countering smuggling and other aggressions were some of the key challenges faced by the Service. This period was marked by disorder and disintegration. Japanese entry into the Pacific War marked a new stage of relations for foreigners in China and so, too, for the CMCS. And the immediate post-war period did not see an end to the challenges faced by the Service. As a consequence of this exploration, this chapter 
will also reflect on how tightly bound the Customs Service was to the position and British interests in the Far East.

\section{Japanese ambitions and the Customs}

Japanese interests in the CMCS remained unabated from the early 1930s onwards. It may be argued that Japanese occupation of Manchuria and control of the Customs houses there gave Japan an even bigger economic interest in China. ${ }^{1}$ Following from the Japanese occupation of Customs houses in the north-eastern provinces, considerable pressure was brought to bear to ensure a Japanese staff member remained in a position of influence within the Service. Maze wrote on this matter to Sir John Simon, Britain's Secretary of State for Foreign Affairs in June 1935. ${ }^{2}$ In this letter Maze outlined that the ascendancy of Japanese influence in the politics of the Far East had made the position of the CMCS and the role of the Inspector General (IG) increasingly delicate. According to Maze, the Japanese insisted that one of their nationals must hold a position close to the IG, in this case that of the Chief Secretary. Subsequently, Commissioner Kishimoto was appointed to the post. ${ }^{3}$ There was also the understanding that if the post of Deputy IG was revived then it was expected that a Japanese national should be appointed - this position was a significant one as it usually denoted the successor for the IG's position. Maze was confident, however, that no Japanese would ever be appointed IG owing to Chinese opposition.

As the creation of a Japanese-led, autonomous region in north China became more apparent, Maze began to formulate plans to keep the CMCS intact. ${ }^{4}$ Maze proposed to follow the basic line of compromise that he had devised in 1932. This would see the Customs remaining intact and staff holding their posts undisturbed. After deducting the cost of administering the northern ports and share of the contribution towards interest of the foreign and domestic loans, the balance would remain with the northern authorities. Internal division within the Chinese political scene also compounded the difficulties the service faced. In this issue, Maze showed the pragmatism that had become something of a trademark of his administrative style. Not only did Maze see compromise as the best solution in relation to the Japanese, he also intended that the Guangzhou faction and other independent factions in China should be encouraged to preserve the Service. Compromise was the key to this solution; Maze believed he could concede non-essentials while standing firm on the essentials when necessary. ${ }^{5}$ The preservation of British influence in the Inspectorate was a priority.

In early 1937 the North-China Herald $(\mathrm{NCH})$ published an editorial on the strength of the Service as an asset to China. This article praised the ability of the CMCS to service foreign loans in spite of the loss of revenue from Manchuria and Dalian. One passage reads: 
Amid the succession of upheavals, disappointments, disasters and uncertainties, it seems to stand as the sure rock against which the waves of misfortune dash helplessly if noisily. On it foreigners and Chinese depend for the preservation of the fabric of commerce against the ills of political and economic misfortune. ${ }^{6}$

The role of the CMCS in facilitating trade is depicted here as the key to all commerce in China. Moreover it was being equated with stability for China and China traders. This article gave unreserved support for the Service and Maze's leadership, praising their resolute stance despite 'an orgy of smuggling' in the north. The Japanese were criticized in this article as 'patrons of an ad hoc smugglers paradise'. Clearly the foreign community in Shanghai (and no doubt elsewhere) were uneasy with events unfolding in the north, particularly as smuggling undermined their interests and trading concerns. This article framed these concerns in terms of being expressions from 'friends of Japan', reflecting the tensions emerging between the desire to remain on cordial terms with the Japanese in spite of their actions in China. This article was indicative of the concerns facing the Service as it encountered increasing turbulence from 1937 onwards.

When confronted with the advancing Japanese military in China, the predominant concern for Britain was the preservation of its economic interests. While there was growing sympathy for China in the face of successive Japanese aggressions, British foreign policy remained conciliatory towards the Japanese. ${ }^{7}$ This attitude remained even after the outbreak of the Sino-Japanese War. In part, this was a realization that Britain was no longer in a position where it was capable of defending itself against European aggressions as well as deploying its forces in the Far East. ${ }^{8}$ In both 1937 and 1938 discussions took place between the British and the Japanese, focusing on creating a better understanding between the powers and also on the protection of British interests in Japanese-held areas. ${ }^{9}$ Even after this time, when British-owned properties were attacked, the British took a passive stance in relation to events. This would not have been lost on the Chinese Government, fuelling anti-British sentiment that the GMD already harboured.

British foreign policy was reflected to some extent through British businesses in China. The preference for conciliation can be evidenced through the actions of the British merchants and enterprises in China who were determined to continue their businesses despite Japanese invasion. Christopher Briggs (Captain of the Customs launch Huashang, stationed in Zhifu) recalled that as the Japanese military advanced and reconnaissance planes began to appear over Zhifu British businesses painted Union Jacks on the roofs of their premises with the belief that this would spare them from attack. ${ }^{10} \mathrm{He}$ also recounted that the Customs had a flagstaff and flew the British flag at this time (it is not clear if this was sanctioned by the Service as a means to keep the Customs safe), giving a sense of the 
ambiguous position of the CMCS as a foreign-staffed but Chinese institution. This ambiguity became an ongoing problem for the Service and its position in relation to British interests in China.

Tensions between the Chinese and Japanese forces reached boiling point following the 7 July Marco Polo Bridge Incident and erupted into armed clashes. The subsequent advance of Japanese troops into north China had an immediate impact on the functioning of the Service. Zhifu provides a good example of this. By the time Japanese warships arrived in Zhifu harbour CMCS vessels had already been confined to the harbour for some time. This was due to concerns for safety, considering there were many warships operating in the water. Briggs was notified that his ship was not to go to sea without permission and a Japanese sentry on board. While this practice did not continue for long (Briggs recounts the Japanese sentry's sea-sickness while facing a rough sea), it gives an indication of the attempts to monitor and control the daily functioning of the CMCS. Later, the Customs Commissioner was replaced by a Japanese Commissioner. Briggs reflected on the feeling among the staff of the Customs:

We were, naturally I suppose, very anti-Japanese. They had started a war against a China that employed us and treated us well. . . . A feeling of insecurity and fear interrupted our peaceful and relaxed attitude to life and our prospects for the future were beginning to look uncertain. We were prepared to do anything which would embarrass the unwanted invaders, without getting ourselves or even the Customs into trouble. ${ }^{11}$

For the foreign staff of the Customs, as with other larger foreign community, there was an uneasiness and fear of the 'unpredictable' Japanese military, despite the belief that this conflict would remain between China and Japan. For the foreign Customs staff, the risks were greater as they were working for a Chinese institution.

By 1937 smuggling was rampant in the north-eastern provinces but also in other parts of China. The preventive department of the CMCS could not cope with the scale of smuggling and the accompanying aggression it encountered. In the $\mathrm{NCH}$ for 1937 rarely a week passed without reports on smuggling, clashes with smugglers, or complaints by the Japanese against Customs officers for infringements, real or imagined. Smuggling was particularly bad in Tianjin and it was reported that in a two-week period in January a total of 60 trucks had forced their way through the customs barrier, escorted by Japanese and Koreans. ${ }^{12}$ Many more trucks used other roads to travel inland with their goods. Thus Customs officers' observation on this matter would only have represented a small proportion of the actual amounts smuggled. Four categories of contraband were commonly smuggled: artificial silk yarn, cigarette paper, sugar and kerosene. ${ }^{13}$ Smugglers in Tianjin seized the CMCS station at Small West Gate at night and used this as a base for escorting convoys of their contraband. 
Moreover, in Tianjin in 1936 an estimated \$50,000,000 duty was lost through smuggling. ${ }^{14}$ Xiamen and Fuzhou were featured in articles detailing the challenges the CMCS faced with smugglers. ${ }^{15}$ This in itself provided an indication that smuggling was not solely the bane of the northern ports but rather was afflicting all of the coastal regions to some extent. To thwart smugglers the preventive service devised three lines of defence: the first being larger patrol boats at sea, the second consisting of fast motor launches along the coast, and the third being land stations. ${ }^{16}$ These measures were insufficient to effectively stem the flow of smuggling. This was a disheartening situation for the Service and one that was fraught with danger for staff.

Smuggling not only affected revenues and trade but brought an element of danger to the work of Customs officers. A number of officers were injured by smugglers or in encounters with suspected smugglers. In one instance near the Guangxi border a Customs party was ambushed while attempting to seize smuggled goods that had been hidden in an omnibus station. The Customs men retaliated with gunfire and withdrew but a Briton, Boat Officer Paget, was killed and a Chinese guard was injured. ${ }^{17}$ Customs officers were constantly at risk, with land patrols coming under fire, and, in the north, fierce resistance from Japanese and Korean smugglers. ${ }^{18}$ Customs cruisers often had to fire warning shots across the bow of suspicious vessels that refused to stop for inspection. ${ }^{19}$ And then boarding such vessels was dangerous as often the crew were armed and prepared for a clash.

Sea- and river-going vessels in the Service were affected by Japanese aggressions both in terms of control of the vessels and carrying out their duties. A number of CMCS cruisers were seized or sunk while trying to elude capture by Japanese destroyers. These included the Shungiing and the Kwanwei. A report by Maze to the Chinese Government raised the issue of Japanese victimization of CMCS vessels. This detailed two vessels, not operating but docked in Ningbo, which were bombed and machinegunned by Japanese aircraft. ${ }^{20}$ Subsequently, the Customs Cruisers in Shanghai were taken over by the Japanese army, CMCS crews were led ashore and replaced by Japanese and the 'rising sun' flag was hoisted. While the Japanese took over all vessels in Shanghai, including the dredging vessels, they did not engage in harbour maintenance. The resultant silting of the Huangpu raised serious problems for all vessels seeking to dock or depart from Shanghai's deteriorating harbour. ${ }^{21}$

From the outbreak of war, Customs vessels were under threat of capture by the Japanese and some were anchored in Hong Kong for safety. The issue had arisen, however, of the possible sale of these preventive cutters to the British Naval authorities. ${ }^{22}$ Maze expressed grave reservations at this possibility, fearing it would provoke trouble from the Japanese authorities should they learn of it (this was later blamed for provoking the Japanese move against the Customs in Shanghai). In addition, the ability of the Customs to carry out their duties with regard to preventive works and harbour-side customs inspections was severely curtailed in the northern 
regions and inspections on land were increasingly difficult. Protection was not always afforded by Hong Kong waters. In the case of the Zhaxing, the cruiser was shelled by a Japanese destroyer and the Captain tried to make a break by heading into Hong Kong waters but ended up beaching the vessel. ${ }^{23}$ The crew then made safe their escape. The Japanese destroyer then towed the cruiser back into Chinese waters. This vessel then became a spoil of war.

The fate of the CMCS roused British concerns. The British Foreign Office was keen to safeguard the Customs as the repayment of foreign loans was directly linked to this Service. So when Japanese threats came to Tianjin in August 1937, there was trepidation that the Service would be lost. Certainly, there had been other challenges to the integrity of the CMCS but these had come from factions within China or within the Service (the succession struggle), but this was altogether different. At the crux of this was the Japanese concern that revenues would be used to fund the Chinese resistance or war effort. Therefore allowing the Chinese any access to funds from occupied territories made no sense. The British feared the Japanese might take drastic action and so they encouraged compromise. Ideally, revenue could be placed in the Yokohama Specie Bank but foreign loans would be repaid. However, in negotiations Commissioner Myers in Tianjin (under significant pressure from the Japanese) overreached this mark, as all revenues were placed in the Yokohama Specie Bank, including remittances for foreign loans. ${ }^{24}$ This was a much larger concession than had been predicted or desired by the British Foreign Office, or the Service.

In November the Japanese made it clear they wanted half of Shanghai's revenues. The British Foreign Office attempted to negotiate so that all revenues would be placed in a neutral bank but, in the end, an agreement was struck whereby all revenues (including those already held in the Hong Kong and Shanghai Bank) would be transferred to the Yokohama Specie Bank. From this, foreign loan obligations would be filled. By December a Japanese Commissioner was appointed to the Shanghai post. In addition the duties of appraisal and examination were taken over by Japanese staff. These Japanese officials were, however, operating under the nominal control of Maze, as the IG. ${ }^{25}$ The actions of the Japanese in Shanghai were not as cautious or slow as they had been with the takeover of the Customs houses in the north-east, where these takeovers had been preceded by warnings, representations and the like. In this instance, the Japanese took advantage of the momentum gained through their military offensive. And by December 1937 they had asserted their control in Shanghai.

Unsurprisingly, the Chinese Government refused to capitulate to this British effort at appeasement. For the Nationalists, challenges came from Japanese aggressions but were also present in the tenuous United Front formed with the Communists. This united stance against the common foe had unraveled by 1939 so the GMD then faced challenges that were both external and internal in nature. The challenges to the CMCS were 
symptomatic of an external threat; however they did not allow Maze to transfer the funds from the Hong Kong and Shanghai Bank. For Maze, this was a difficult situation as he was torn between British agreements and priorities and the wishes of the Chinese Government. He was also under constant pressure from Japanese interests in the Service. No matter how skilled his diplomacy, it was obvious that Maze could not devise a plan to satisfy all of these interests while maintaining the integrity of the Service.

The Customs Agreement of May 1938 focused particularly on the Japanese controlled treaty ports. In essence this saw the British recognition of the right of the Japanese-controlled autonomous regional governments in China to take over the Customs service. It also saw the British giving up their claim to the Hong Kong and Shanghai Banking Corporation's custody of Customs funds. ${ }^{26}$ This raised protest from the Chinese Minister of Finance, Kong Xiangxi (better known as Dr H.H. Kung), and from within the Service. All future revenues were, however, placed in the Yokohama Specie Bank, and, from this time, the Japanese were more restrained towards the CMCS. ${ }^{27}$ China continued to service foreign loans until January 1939. In contrast, the issue of the repayment of domestic loans had long been overlooked. To some extent these negotiations reveal the source of Maze's frustration. Despite British assurances that the CMCS was a priority, they were prepared to sacrifice its integrity as a Chinese institution for the sake of appeasing Japanese interests and ensuring the Japanese did not take over the Service. Safeguarding their own economic interests was a priority and as long as foreign loans were being repaid then they would be satisfied. This policy of appeasement was pronounced after the war in Europe commenced.

Japanese administration of the Customs within the Japanese-controlled territories left much to be desired. The system was described as 'breaking apart'. ${ }^{28}$ A revision of the tariff scheme led to the favouring of Japanese goods but reportedly many commodities were brought duty-free into China under the guise of supplies for troops. Accompanying this was the perfunctory searching of Japanese vessels. Japanese soldiers were reported as levying internal transport charges through threat of force rather than any authorization..$^{29}$ All of these factors combined to undermine trade and revenue. For the Chinese Government, Customs revenues were diminished and yet war costs kept rising. Deficit spending was already a problem for the GMD and issuing of new currency led to inflation rather than alleviating the situation.

\section{The Pacific War and implications for the CMCS}

With the bombing of Pearl Harbor in December 1941 the United States entered the World War. China then fell under the 'American sphere of influence' for the Pacific War and aligned itself against the axis powers. ${ }^{30}$ This brought the China front into World War considerations (moreover, 
Japan's rapid victories against the allies led to a renewed interest in the China theatre as the Chinese forces had been fighting the Japanese for many years). With the outbreak of the Pacific War, internment and the fear of persecution loomed large for Customs staff. The Customs establishments still operating under Maze's nominal control in occupied China were seized in December and American and British staff interned. Despite assurances by the Japanese authorities that he would remain unmolested, Maze was seized on 5 March 1942 by the Japanese Gendarmerie. He was detained and interned in Shanghai's notorious Bridge House for questioning. Maze wrote of this experience and the deprivations he suffered. $\mathrm{He}$ recorded that he was:

Thrown into the noisome felon's prison known as the 'Bridge House'. It is divided into six so-called 'old cells' about 20 feet by 10 feet and six 'new cells,' somewhat larger. I was domiciled in one of the latter. ... My prison associates, in addition to a few foreigners, included Chinese thieves, murders and bandits, etc ... most of the lower class Chinese occupants were suffering from various loathsome skin diseases and their clothes were alive with vermin. ${ }^{31}$

Maze was detained for four weeks. Following this internment, he was repatriated to Durban. It was after this that he decided to return to China and to the wartime capital to resume his duties.

In December 1942 Maze arrived in Chongqing and described the Customs situation as both 'confused and difficult'. ${ }^{32}$ He firmly believed that his internment had allowed the Chinese to curtail the influence of the IG, taking away the prestige and authority of this post. The Service too had been affected. He commented:

I think they [the Chinese government] propose to make the Service a purely Chinese subordinate Department of the Ministry, as it has been in theory but not in practice - witness the present predicament of the Postal and Salt Departments. ${ }^{33}$

Maze was not wholly surprised by what he perceived as an inevitable reduction in the role of the Service, most particularly as he believed China had come to political maturity. With China now at the 'forefront of world events' he sympathized with their desire to cast aside foreign interference. What he did not agree with was the methods undertaken to reduce the standing of the Service. He reflected that his own actions in preventing the appointment of further foreign staff from 1930 was part of this preparation for Chinese staff to take over control of the Service. And when in Spring 1943 Maze was requested to submit plans for the post-war rehabilitation of the Service he suggested recalling retired foreign 
CMCS men but only on a contract basis. ${ }^{34}$ This again reflected Maze's sympathies with the Service becoming a truly Chinese institution.

While returning to China, Maze did not intend to not remain in Chongqing for the long term to administer the Service..$^{35}$ In May 1943 Maze announced his resignation from the CMCS and his intention to depart from China. He cited ill-health as a major factor in his decision. By this stage he had served in the CMCS for just over 50 years and his internment experiences coupled with the tensions and hardships during wartime would no doubt have taken their toll. In correspondence, however, ill-health receives little attention and rather Maze identified the decline of British status in the Far East (following the fall of Hong Kong and Singapore) and the shifting of Chinese public opinion towards the Americans (following American loans to China) as the factors that had made his position untenable. ${ }^{36}$ In his estimation then, it was larger political forces that had brought Maze's leadership to an end.

Events leading up to Maze's resignation revealed tensions surrounding the leadership of the Service. Apparently much of the resentment on the part of the Chinese Government was that Maze had been instructed by Generalissimo Jiang to remove the Inspectorate to the wartime capital as early as 1940 . Maze claimed that he had never received these instructions and therefore had not relocated the Inspectorate. Countering these claims was Kong's assertion that Maze had been issued these instructions but refused to comply. Rather than embarrassing Kong and disputing such comments, Maze had allowed Kong to 'save face' and to restore the good standing of the Customs. ${ }^{37}$ This took some time but Maze believed this decision was important for maintaining the goodwill of supporters of the CMCS.

In London The Times carried an editorial titled 'Foreigners in China', reporting Maze's resignation and reflecting on his career. This article lamented Maze's ill-health stemming from his imprisonment as the factor that had led Maze to relinquish leadership of the Service. The editorial praised Maze as a capable administrator with 'a warm sympathy for progressive movements in China, and a sure political instinct'..$^{38}$ And furthermore it reflected that Maze's resignation marked the end of a third stage for the Customs (the first being its inception, the second the leadership of Aglen). Of note is the reference to the CMCS as an institution of a bygone era: 'Though much which the institution represented belongs to a now buried past, it will deserve to be remembered as a model of disinterested efficiency and of practical international service. ${ }^{39}$ Certainly the glory days of the CMCS were long past, and so too its era of wielding great influence in China's affairs. This was what Maze himself had greeted as an inevitable progression. The idea of the Service as providing 'disinterested efficiency' is a curious one; this institution had long balanced between foreign and Chinese interests and often had a partisan role in events. The cessation of British leadership effectively brought to an end public concern (from home) with this service. 
Maze's resignation was tinged with disappointment. He reflected: 'I must confess that after 50 years' service I expected better treatment than I have received at the hands of the Government. ${ }^{40}$ Although Maze resigned from the Customs he remained in an advisory role to the Chinese Government. ${ }^{41}$ $\mathrm{He}$ also responded to requests from various Chinese communities by broadcasting appeals for medical supplies for China. ${ }^{42}$ In this way he could draw on his standing as a long-time advocate for China in the international arena. Maze's position as Adviser to the Ministry of Finance was limited by the fact that he remained overseas and in his correspondence there is no indication that he intended to return to China. Moreover, once the war had ended, the need to reorganize the CMCS was paramount, and this led to an examination of its administrative funds, which in turn provided the rationale for abolishing this advisory post in November $1945 .{ }^{43}$ It is arguable that this would have happened as a matter of course and Maze did not express any surprise in his correspondence that his services were dispensed with.

The decline of British influence and interest in the CMCS reflected the general decline of Britain in the Far East. The British were in a dilemma as they had substantial interests in the Far East but lacked the financial means to actively defend them. ${ }^{44}$ In addition there was strong anti-British sentiment among the Chinese leadership (something that Maze himself reflected upon), which further heightened British fears. In contrast, American actions in China had often been linked with philanthropic works and education, creating a positive impression. American support of China's war effort also further enhanced this goodwill. ${ }^{45}$ British intentions were indeed to remain in China but their promises of economic development and assistance came with a caveat that Britain could only afford to do so after a three- to four-year period.

In an expression of goodwill on the part of the British, 1943 saw the signing of an Anglo-Chinese Agreement. This agreement surrendered British rights and concessions and was intended to herald a new era of equality between the two powers. ${ }^{46}$ This was intended to boost Chinese morale in their fights against the Japanese, but at the same time would also help to preserve British commercial interests in China. In reality however, this agreement was not such a great sacrifice on the part of the British, as the concessions they held (Tianjin for example) had become more of a liability, owing to anti-British sentiment, than a benefit. It also raised more issues than it resolved, as it brought into focus Kowloon territories and their retrocession. And British merchants soon found themselves helpless against discriminatory laws.

In Maze's view anti-British feeling among the Chinese leadership was the key to the decline of the Service. Jiang, in particular, in his view, harboured such sentiments. Maze provided various reasons for what he saw as anti-British sentiment, including Jiang feeling snubbed in respect to international negotiations, the poor treatment of Chinese troops while 
fighting alongside the British in Burma, and also 'an inferiority complex' ${ }^{47}$ This was purely speculative but for Maze this provided some rationale for the way in which the foreign Inspectorate of the CMCS was treated. Maze saw this as compounding the way British interests were 'left in the cold' as now the Americans were dominant in China's affairs. The appointment of an American as the new IG was a reflection on the rising influence of America in the Far East. This appointment was designed to snub the British (according to Maze). Maze had submitted a list of possible successors and, from this, the American citizen Little was selected. This appointment thus ended British leadership of the CMCS and reinforced the demise of British influence in the Inspectorate.

Maze appeared to have something of a tense relationship with his successor, Little, evidenced through a terse exchange of letters relating to the custodial rights of Hart's correspondence. The tensions surrounding these papers may have been an outlet for asserting authority with regard to the CMCS and Maze's reluctance to relinquish his control. Maze's decision to withhold some confidential and private documents from his successor illustrates this tension. ${ }^{48}$ There is also no evidence of Maze corresponding at great length with his successor; this is surprising as Maze's correspondence reflects ongoing contact with many members of his staff. The general impression is that Maze remained aloof from this new leadership of the CMCS but did maintain contact with senior Chinese staff.

New leadership was not the only change for the Service. Foreign CMCS staff could no longer look with certainty to the Service for their livelihood. What had been a relatively assured career in the Service was thrown into disarray by the 1940s. Life in the Service and, indeed, in treaty port China had effectively changed forever. Customs staff had encountered serious challenges during the war years including intimidation, attack and, finally, internment. Furthermore, many had not received salaries since December $1941 .{ }^{49}$ Compounding the issue was the fact that the issue of emoluments for interned foreign staff was slow to be addressed. Employment opportunities were available in the Abyssinian and Iraqi Customs and, in light of the difficulties faced by staff wishing to remain in China, Maze expressed the view that staff should consider such positions. ${ }^{50}$ Many staff also looked to the British Commonwealth for their livelihoods.

During the War, the Japanese had seized property belonging to internees. After the War, Chinese authorities took over these properties. According to the principles of the 1943 Anglo-Chinese Agreement these properties should have been returned to their British owners; however, this was rarely observed as the Central Government could not effect observance from its subordinates..$^{51}$ Numerous representations on this matter were made by the British before property was returned. Even by 1949 there were still difficulties in this regard. ${ }^{52}$ British shipping was also affected by tough new trade sanctions, and this in turn affected the Customs. 
In the case of Customs staff, personal belongings were lost. In Shanghai, staff had locked their belongings into the Customs godown for safekeeping. All personal effects were, however, handed over by the Japanese to the 'Enemy Property Control Commission' in February 1944 and were considered lost. ${ }^{53}$ It was later realized that these items had been auctioned. Similarly, after the war, when efforts were under way to recover and account for belongings, opportunism abounded and Chinese staff enlisted to created invoices were often suspected of theft (considering the post-war economy it may not be too surprising that some staff would give in to the temptation to avail themselves of goods that could be sold or traded). Even items sent outside China were not safe. Maze had sent cases of papers (both personal and semi-official in nature) and other valuables to Singapore (Britain's fortress in the south-east) for safekeeping, but with the fall of Singapore in 1942, these belongings were scattered and jewellery stolen. ${ }^{54}$ This loss of personal property in addition to internment was a blow to Customs staff, many of whom were left with little after building collections during lengthy careers in China.

In the post-war period, Little had to reorganize and rebuild the Service. The CMCS needed to reorganize and re-staff but there was official resistance against the return of foreign staff, although in some instances (for instance the Marine Department) their expertise was needed. All technical staff, including marine officer and examiners, were called back to China. Some indoor staff were also asked to return but the return of many foreign Commissioners was contentious. ${ }^{55}$ Moreover, the prospects for ex-CMCS staff were not good enough to induce them to return to their former posts. Many ex-Customs men were dealing with post-war legacies of dislocated families and this may account for some reluctance on their part to venture to China again. Little's attempts to lure these men back to the service had mixed results. Severe inflation and domestic turmoil were disincentives; an additional deterrent was that wives were not permitted to return with their husbands. This no doubt decided the question for many of these former Customs men. ${ }^{56}$ There was mention, however, of some 40 to 50 men who would be returning to China between May and September 1946.

Despite efforts to rebuild the CMCS it was difficult to operate in an environment of domestic turmoil. The Service faced its most serious challenges as inflation and civil war took hold of China. The CMCS had ceased to function as a strong national institution, and its foreign inspectorate was a mere shadow of its pre-1937 form. The late 1930s to 1945 marked the demise of British interests in the Customs Service. It is fair to say that by this time the CMCS had ceased to exist as a British concern and had become more of a liability for British interests in China. The appointment of an American IG confirmed this new focus of Chinese interests and so too signalled the end of British dominance in this once powerful but now demoralized institution. 


\section{In the final analysis}

To conclude then, this work has traced the gradual decline of the CMCS as an imperial institution. Contrary to Hart's predictions and Aglen's misgivings that the CMCS could not survive in the Republic, this work has shown that the Service responded dynamically to numerous forces of resistance and change that confronted and challenged its existence. This resistance manifested itself in both Chinese and British/Western responses to the Service. What the CMCS could not resist was the upheaval wrought by war and then the demise of the treaty port system. With the end of the treaty port system much of the rationale of the Service had vanished.

This work has explored particular junctures where the existence and nature of the Customs was challenged, including the Guangzhou Customs crisis, the Guangzhou-Hong Kong boycott, the Customs succession struggle, the negotiations over a Hong Kong Customs agreement and the seizure of the Tianjin Customs followed by Japanese aggression in the north-east. By examining these threats against the Service and responses to them, this work serves to highlight the shifting significance of the Customs as a foreign institution, while at the same time providing insight into perceptions of identity within the Service.

In many ways the psyche of the Service remained constant, despite many challenges. From its inception right through to its decline, there was an overwhelming sense of mission in maintaining the CMCS for the good of China, but this was always tempered with a consciousness of the British and other foreign interests that the Service protected. The present work has recorded an account of Britain's shifting perceptions of the Service and has shown how the Customs can often be seen as indicative of larger forces at play in Sino-Western relations. In 1923 the Service had been seen as a foreign concern, to the extent that gunboat diplomacy was employed to dissuade Sun from interfering with foreign interests, but by 1932 the British were hesitant even to protest unofficially the seizure of the north-eastern Customs houses by the Manzhuguo authorities. The fate of the CMCS reflected the decline of Britain and the West in China and the general demise of the privileged life enjoyed by the foreigner in the treaty ports.

From the 1920 s it is possible to trace a decline in the status and cohesiveness of the CMCS as an institution with national scope. This accelerates in the 1930s with a de-evolution of the Service occurring during the war years. Threats against the Service, whether successful or not, all served to emphasize the tenuous base that this institution functioned from. The attacks against the Customs in the 1930s signalled the demise of the service. And this was further accelerated through the Sino-Japanese War and the subsequent World War.

A frustrated and isolated Maze clung to the belief that he was defending British interests in China through the Customs service, but the British establishment had long since abandoned this view. Once the physical 
integrity of Service had been breached, however, there was little that could be done by Maze or the British to lessen the damage. The Service had relied on its image as being able to function largely separate from the Chinese political situation, a belief that was a dangerous illusion. Under Little's leadership the CMCS did not fare any better as by this stage the influence of this institution had been eroded.

The CMCS, the best friend of China, had been dealt a heavy blow with the loss of the Customs establishments in the north-east. But the decline of the Service did not end here. The forces of change and resistance continued to play themselves out and by the mid-1930s the Service struggled to maintain the semblance of its former cohesive structures. The Service was very much a product of its era, growing out of the treaty port system, and reliant to a large extent on the continued goodwill of not only the Chinese authorities but also the interested foreign powers. And until the Sino-Japanese War, foreign interests in loan repayments and the continuation of existing trade won out over any other concerns for the bitter struggle that was engulfing China.

Thus, over 40 years after Hart had prophesied that the Service, would collapse, the foreign inspectorate ceased to operate in treaty port China. The CMCS had survived for the duration of the treaty port system and beyond but was no match for the new wave of patriotism that was sweeping China in the form of the Communist Party. There was no place for this remnant of foreign imperialism with its ties to the Nationalist era in the new People's Republic of China. Vestiges of this international service remain, however, in the voluminous archives documenting trade, in service reports, in the lighthouses and charting of rivers, in photographs, through reminiscences of careers on the China coast, and in architectural legacies such as the Customs Inspectorate building with its imposing clock tower, which still graces Shanghai's Bund. 


\section{Notes}

\section{Preface}

1 Sir Frederick Maze, letter to Alexander Cadogan, 21 Dec. 1943, The Maze Collection, ms., National Maritime Museum, Greenwich. The Maze Collection is a loose set of documents and other material that have not been previously catalogued. As such it has no official title and the use of the term, Maze Collection, is strictly for the convenience of this thesis. These boxes of materials however, were informally catalogued by the author for the Museum in 1997.

\section{Introduction}

1 See Nicholas Clifford, Retreat from China: British Policy in the Far East 1937-1941, London: Longmans, 1967, and Edmund S.K. Fung, The Diplomacy of Imperial Retreat: Britain's South China Policy, 1924-1931, New York: Oxford University Press, 1991.

2 See Robert Bickers, Britain in China: Community, Culture and Colonialism 1900-1949, Manchester: Manchester University Press, 1999.

3 See Clifford, Retreat from China; Fung, The Diplomacy of Imperial Retreat; Thomas G. Rawski, Economic Growth in Prewar China, Berkeley: University of California, 1989; Britten Dean, 'British Informal Empire: the Case of China', The Journal of Commonwealth and Comparative Politics, 14 (1976): 64-82.

4 Jürgen Osterhammel, 'Semi Colonialism and Informal Empire in Twentieth Century China', Imperialism and After: Continuities and Discontinuities, eds Wolfgang J. Mommsen and Jürgen Osterhammel, London: Allen and Unwin, 1986, p. 291.

5 See Osterhammel for an excellent discussion on these divergent approaches to imperialism in China.

6 Rawski, Economic Growth.

7 Anthony Kirke-Greene, Britain's Imperial Administrators, 1858-1966, London: Macmillan, 2000 and On Crown Service: A History of HM Colonial and Overseas Civil Services 1837-1997, London: Taurus, 1999.

8 Alex McKay, Tibet and the British Raj: The Frontier Cardre 1904-1947, Richmond: Curzon, 1997.

9 Julia C. Strauss, Strong Institutions in Weak Polities: State Building in Republican China 1927-1940, Oxford: Clarendon, 1998.

10 Chi-Kong Lai, 'The Historiography of Maritime China Since c. 1975', Research in Maritime History, 9 (1995): 53-79.

11 There are only two English language works examining the Customs service in the Republican period: Jean Aitchison, 'The Chinese Maritime Customs Service in the Transition from the Ch'ing to the Nationalist Era: An Examination of the 
Relationship Between a Western-style Fiscal Institution and the Chinese Government in the Period before the Manchurian Incident', diss., London University, 1983; Martyn Atkins, Informal Empire in Crisis: British Diplomacy and the Chinese Customs Succession, 1927-1929, Ithaca: East Asia Program, Cornell University, 1995.

12 This is discussed in the commentary accompanying Robert Hart's journals: Katherine F. Bruner, John K. Fairbank and Richard J. Smith (eds) Entering China's Service: Robert Hart's Journals, 1854-1863, Cambridge: Harvard University Press, 1986, Epilogue, pp. 332-8.

13 Francis Aglen, letter to Acheson, 28 February 1922, Letter Series Z, Library of the School of Oriental and African Studies, London.

14 Sir Frederick Maze, 'The Chinese Maritime Customs Service: a brief synopsis of its genesis and development' (c.1940, National Maritime Museum, Greenwich, N3125. 12-page pamphlet). This perception of parallels between the Indian Civil Service (and other colonial institutions) and China's Maritime Customs Service is a current research interest for the author.

15 See S.F. Wright, The Collection and Disposal of the Maritime and Native Customs Since the Revolution of 1911, With an Account of the Loan Services Administered by the Inspector General of Customs, 2nd ed. Shanghai: Statistical Department of the Inspectorate General Of Customs, 1927; and China's Struggle for Tariff Autonomy: 1843-1938, Shanghai: Kelly and Walsh, 1938.

16 Francis Aglen, letter to Cecil Bowra, 17 May 1926, Letter Series Z,

17 S.F. Wright, Hart and the Chinese Customs, Belfast: Mullan, 1950, p. 7.

18 Ibid., p. 103.

19 Ibid., p. 7.

20 Ibid., p. 8.

21 The following works trace Fairbank's own development of the synarchy thesis: John King Fairbank, Trade and Diplomacy on the China Coast: The Opening of the Treaty Ports 1842-1854, Cambridge: Harvard University Press, 1953; 'Synarchy Under the Treaties', in Chinese Thought and Institutions, ed. John King Fairbank, Chicago: University of Chicago Press, 1957; 'The Early Treaty System in the Chinese World Order', in The Chinese World Order: Traditional China's Foreign Relations, ed. John King Fairbank, Cambridge: Harvard University Press, 1968.

22 Atkins, Informal Empire in Crisis, pp. 41-51.

23 See Britten Dean, 'British Informal Empire', and Osterhammel, 'SemiColonialism'.

24 Bickers, Britain in China, pp. 120-2.

25 Nicholas R. Clifford, 'Sir Frederick Maze and the Chinese Customs, 1937-1941', Journal of Modern History, 37.1 (1965), p. 20.

26 Aitchison, 'The Chinese Maritime Customs Service', Chapter 4.

27 Max Weber, 'Authority and Legitimacy', in Politics and Society: Studies in Comparative Political Sociology, ed. Eric A. Nordlinger, Englewood Cliffs: Prentice Hall, 1970, pp. 35-44.

28 Julia C. Strauss, Strong Institutions in Weak Polities, pp. 63-75.

29 Wright, China's Struggle, p. ix.

30 Jonathan D. Spence, God's Chinese Son: The Taiping Heavenly Kingdom of Hong Xiuquan, London: Harper Collins, 1996, pp. 46-50. This section deals with the dreams and delirium that Hong experienced and later interpreted as evidence of his divine destiny.

31 See J.S. Gregory, Great Britain and the Taipings, Canberra: Australian National University Press, 1969 for an interesting review of British (and other Western) reaction to the Taiping Rebellion.

32 Wright, Hart And The Chinese Customs, p. 89. 
33 Maze, 'The Chinese Maritime Customs Service'.

34 Paul Hibbert Clyde, ed., United States Policy Towards China: Diplomatic and Public Documents, 1839-1939. Selected and arranged by Paul Hibbert Clyde, New York: Russell and Russell, 1964, pp. 30-4.

35 Ibid., Minutes of a conference held at Shanghai, June 29, 1854. Section 3, 31.

36 Hoppo Hung, translation of letter to C.A. Winchester, 13 Oct. 1859, in Chinese Maritime Customs Service, Documents Illustrative of the Origin, Development and Activities of the Chinese Customs Service, Shanghai: The Statistical Department of the Inspectorate General of Customs, 1940, vol. 6, p. 71. These volumes will be referred to with an abbreviated title of Documents followed by Volume details.

37 Robert Hart, letter, 27 May 1859, Documents, vol. 6, pp. 69-70.

38 H.N. Lay and S. Osborn, agreement, 16 Jan. 1863, Documents, vol. 6, pp. 133-4.

39 Article five of the agreement was particularly offensive to the Chinese. It stated that Lay, 'upon his part, engages to refuse to be the medium of any orders of the reasonableness of which he is not satisfied'. Ibid.

40 Prince Kung, 'Translation of a dispatch from Prince Kung to Sir F.W. Bruce on Sherard Osborn fleet', 25 October 1863, Documents, vol. 6, p. 136.

41 For a detailed account of the early years of the Customs see Wright, Hart and the Chinese Customs, p. 250.

42 Prince Gong, dispatch to Robert Hart, 15 Nov. 1863, Documents, vol. 6, pp. 143-5.

43 By the Republic the British Foreign Office had a much closer relationship to the CMCS and was directly involved in a succession struggle to appoint their approved candidate as IG.

44 Prince Gong, Documents, vol. 6, p. 145.

45 Plates of the Statue of Sir Robert Hart, Shanghai. Taken from inscription on the West face of statue of Hart, erected in 1914 on The Bund, Shanghai in Chinese Maritime Customs Service, Decennial Reports 1912-1921, Shanghai: Inspectorate General of Customs, 1924.

46 Robert Hart, The I.G. in Peking: Letters of Robert Hart, Chinese Maritime Customs 1868-1907, eds John King Fairbank, Katherine Frost Bruner and Elizabeth MacLeod Matheson, Cambridge: Belknap Press, 1975.

47 Wright, Hart and the Chinese Customs, p. 286. This was Rule 10 of the Tientsin Treaty rules of trade.

48 Albert Feuerwerker, 'The foreign presence in China', in Republican China 1912-49, vol. 12, part 1 of The Cambridge History of China, ed. John King Fairbank, New York: Cambridge University Press, 1983.

49 Hart, 2 Oct. 1874, letter 115 of The I.G. in Peking, vol. 1, p. 182.

50 Robert Hart, 'The Customs Service, the spirit that ought to animate it, the policy that ought to guide it, the duties it ought to perform; general considerations and special Rules [sic]', 21 June 1864, Documents, vol. 1, pp. 36-47.

51 Ibid., pp. 36-47.

52 H.G. Montague Bell and H.G.W. Woodhead, eds China Year Book 1912, Nendeln Liechtenstein: Kraus Reprint, 1972, p. 81. Hereafter, China Year Book will be abbreviated to $C Y B$.

53 Hart, 'The Customs Service, the spirit that ought to animate it', p. 39.

54 Hart, 'The Customs Service, the spirit that ought to animate it', p. 42.

55 This immediately brings to mind Fairbank's synarchy thesis and the spirit of cooperation on which it is theoretically based. The Customs Service may indeed have had a synarchical relationship with the foreign and Chinese powers but within the Service this was not the case.

56 Chinese Maritime Customs Service, Service List 1895, Shanghai: Statistical Department of the Inspectorate General of Customs, 1896 and Chinese Maritime 
Customs Service, Service List 1907, Shanghai: Statistical Department of the Inspectorate General of Customs, 1908.

57 Chinese Maritime Customs Service, Service Lists 1895 and 1907.

58 Wright, Hart and the Chinese Customs, pp. 270-1.

59 Ibid., p. 37.

60 This relationship appears to have been kept quiet and Hart sent his wards to Britain. Hart details his plans for his children's education: he envisaged his daughter, Anna, being schooled on the continent and his sons, Herbert and Arthur, sent to Clifton Hall where they could be trained for the Indian Civil Service. Hart asked Campbell for his assistance in these matters. Hart, 5 June 1875, letter 124 of The I.G. in Peking, vol. 1, pp. 192-3. Hart mentions his wards again in 23 Nov. 1875, letter 138 of The I.G. in Peking, vol. 1, pp. 205-6 and 21 June 1881, letter 333 of The I.G. in Peking, vol. 1, pp. 376-7.

61 See Hart, 9 Oct. 1873, letter 66 of The I.G. in Peking, vol. 1, pp. 127-9; 18 Oct. 1873, Letter 67 of The I.G. in Peking, vol. 1, pp. 130-2; 28 Jan. 1874, Letter 78 of The I.G. in Peking, vol. 1, p. 145; 3 Feb. 1874, letter 79 of The I.G. in Peking, vol. 1, p. 146; 4 Apr. 1874, letter 87 of The I.G. in Peking, vol. 1, p. 152; and 18 July 1874, letter 107 of The I.G. in Peking, vol. 1, p. 173.

62 Hart, 18 Oct. 1873, letter 67 of The I.G. in Peking, vol. 1, p. 131.

63 Hart, 9 Oct. 1873, letter 66 of The I.G. in Peking, vol. 1, pp. 127-9. Hart included some sketches of the uniform in this letter.

64 It is unclear whether this uniform was ever produced for all Commissioners. Sir Frederick Maze was photographed in an elaborate diplomatic-style uniform for his Knighthood presentation in 1930. This uniform is now held by the National Maritime Museum, London.

65 Certainly, the whole brass band movement had emerged in Britain in the 1800s and was closely associated with the protestant working-class ethos. See D. Bythell, 'Class, Community and Culture: The Case of the Brass Band in Newcastle', Labour History: A Journal of Labour and Social History, 76 (1994), for a good introductory work on the successful transplanting of brass bands from England and into the Australian context.

66 Ansom Burlingame, dispatch to US Secretary of State, 20 June 1863, Documents, vol. 7 , pp. $60-1$.

67 Chinese Maritime Customs Service, Decennial Reports 1922-31, Shanghai: Statistical Department of the Inspectorate General of Customs, 1933, p. 84.

68 A.H. Rassmussen, China Trader, London: Constable and Company, 1954, p. 16.

69 Ibid.

70 Hart, 29 May 1887, letter 602 of The I.G. in Peking, vol. 1, p. 665. 'We have several changes coming on now: Drew takes leave, Mc Kean becomes Stat. Secy., Palm goes to S'tow, Ohlmer becomes audit Secy., Spinney Dpy Cmr at Canton ...'

71 Paul King, In The Chinese Customs Service: A Personal Record of Forty-Seven Years, New York and London: Garland Publishing, 1980, p. 245.

72 Hart, 25 Mar. 1869, letter 8 of The I.G. in Peking, vol. 1, p. 49.

73 Hart, 26 Apr. 1873, letter 53 of The I.G. in Peking, vol. 1, pp. 105-6.

74 Bell and Woodhead, $C Y B$ 1912, p. 80.

75 Maze, 'The Chinese Maritime Customs Service', p. 5.

76 Hart, 9 Sept. 1906, letter 1417 of The I.G. in Peking, vol. 2, pp. 1517-18.

77 See Wright, China's Struggle For Tariff Autonomy, for a detailed study of China's tariff development.

78 Wright, The Collection and Disposal, p. 36.

79 As a mark of respect for Hart, all Customs flags were flown at half-mast, and by Imperial Edict Hart was posthumously awarded the title of Grand Guardian of the Heir Apparent, a distinction never bestowed on any other foreigner. F.A. Aglen, circular 1844, 26 Sept. 1911, of Documents, vol. 3, pp. 36-7. 
80 'Sir Robert Hart's Statue', North-China Daily News, 26 May 1914. Hereafter, this paper will be referred to as $N C D N$.

81 F.A. Aglen, circular 1851, 25 Oct. 1911, Documents, vol. 3, p. 39.

82. Chan Lau Kit-Ching, 'The Succession of Sir Robert Hart at the Imperial Chinese Maritime Customs Service', Journal of Asian History, 9, 1 (1975): 1-33.

83 F.A. Aglen, 'War, European of 1914', 8 August 1914, Documents, vol. 3, pp. 199-200.

84 King, In the Chinese Customs Service, p. 276.

85 Chinese Maritime Customs Service, Decennial Reports 1912-1921, Shanghai: Statistical Office of the Inspector General of Customs, 1924. Table showing the distribution of trade of Shanghai among the various nationalities, annual percentage of revenue collected under each flag, 1912-21.

86 F.A. Aglen, memorandum, 28 Jan. 1917, Documents, vol. 7, pp. 233-5.

87 Wright, The Collection and Disposal, p. 21.

\section{An institutional review}

1 Jean Aitchison, 'The Chinese Maritime Customs Service in the Transition from the Ch'ing to the Nationalist Era', diss., School of Oriental and African Studies, London University, 1983, p. 87. In her dissertation, Aitchison provides a representation of the Customs Structure as in 1875. Apart from falling outside the time-frame of this research, there are several ambiguities within this representation. While the definition of such an organization is not an easy undertaking and Aitchison outlines the different branches of the service successfully, what is omitted is a sense of the hierarchy within the CMCS.

2 Chinese Maritime Customs Service, Service List 1911-1913, Shanghai: Statistical Department of the Inspector General of Customs, 1914, p. 184.

3 The need for more senior Customs Commissioners at ports such as Shanghai and Canton reflects the importance of these ports to overall trade. However, this may also relate to the need to respond to growing anti-foreign unrest that was emerging during the mid-1920s.

4 Chinese Maritime Customs Service, The Origin and Organisation of the Chinese Customs Service, Shanghai, Statistical Department of the Inspectorate General of Customs, 1922, p. 10.

5 S.F. Wright, The Collection and Disposal of the Maritime Customs Revenue since the Revolution of 1911, Shanghai: Statistical Department of the Inspectorate General of Customs, 1927, see Chapter 1.

6 Refer to the section later in this chapter on the LO for details of the recruiting process.

7 Yvonne King, personal interview, 26 July 1998.

8 King, personal interview.

9 G.E. Morrison, letter to E. Taylor, 17 Apr. 1917, G.E. Morrison papers, Mitchell Library, Sydney.

10 Ibid.

11 A.H. Rasmussen, Chinese Trader, London: Constable and Company, 1954, pp. 3-4.

12 Ibid., p. 5.

13 C.A.S. Williams, Chinese Tribute, London: Literary Services and Production, 1969, pp. 11-13. Also see Frank H.H. King, ed. A Research Guide to China Coast Newspapers, 1822-1911, Cambridge: Harvard University Press, 1965, pp. 29-30. This provides a brief outline of the Shanghai Mercury an English language newspaper that evolved from other pre-existing presses in 1890 .

14 The move towards a sinicization of the Service is discussed in later chapters.

15 Williams, Chinese Tribute, pp. 56-7. 


\section{Notes}

16 F.A. Aglen, circular 3483, 11 Mar. 1924, Documents Illustrative of the Origin, Development, and Activities of the Chinese Customs Service, vol. 4 Shanghai: Statistical Department of the Inspectorate General of the Customs, 1940, pp. 3-6. In this chapter this series will henceforth be referred to as Documents.

17 Ibid., pp. 3-4.

18 Williams, Chinese Tribute, p. 70.

19 Ibid., p. 69.

20 Ibid.

21 Ibid.

22 Aglen, circular 3483, 11 Mar. 1924, Documents, vol. 4, p. 5.

23 Chinese Maritime Customs Service, Chinese Maritime Customs: Staff Organisation and Control, Shanghai: Statistical Department of the Inspectorate General of Customs, 1936, p. 2.

24 Rasmussen, Chinese Trader, p. 17.

25 Ibid., p. 18.

26 Chinese Maritime Customs Service, Chinese Maritime Customs, p. 17.

27 Ibid.

28 F.W. Maze, Appendix 16, 22 April 1929, Chinese Maritime Customs, pp. 63-5.

29 Chinese Maritime Customs Service, Chinese Maritime Customs, p. 16.

30 King, personal interview.

31 There is much written on guanxi and its importance in Chinese business culture. Here guanxi refers to the cultivation of relationships that may be useful to oneself at some point in the future. John Bryan Starr, Understanding China London: Profile Books, 1997, p. 76.

32 Chinese Maritime Customs Service, Chinese Maritime Customs, , pp. 57-63.

33 Ibid., pp. 57-60.

34 Imperium in Imperio refers to an independent authority claimed or exercised within the jurisdiction of another authority.

35 Francis Aglen, letter to Guy Acheson, 28 Feb. 1922, Letter Series Z, Library of the School of Oriental and African Studies, London.

36 Wright, The Collection and Disposal, p. 21.

37 Hung-Mao Tien, Government and Politics in Kuomintang China, 1927-1937, Stanford: Stanford University Press, 1972, pp. 84-5.

38 Douglas S. Paauw, 'The Kuomintang and Economic Stagnation, 1928-37', Journal of Asian Studies, 16 (1956-7): 213-20.

39 Thomas G. Rawski, Economic Growth in Prewar China Berkeley and Los Angeles: University of California Press, 1989; Stephen Lyon Endicott, Diplomacy and Enterprise British China Policy 1933-1937, Vancouver: University of British Columbia Press, 1975; Tim Wright, 'Coping with the World Depression: The Nationalist Government's Relations with Chinese Industry and Commerce, 1932-1936', Modern Asian Studies, 25.4 (1991): 649-74; Jürgen Osterhammel, 'Imperialism in Transition: British Business and the Chinese Authorities, 1931-37', The China Quarterly, 98 (June 1984): 260-86.

40 P.J. Cain and A.G. Hopkins, British Imperialism: Crisis and Deconstruction 1914-1990, London and New York: Longman, 1993, p. 236.

41 H.G. Montague Bell and H.G.W. Woodhead, eds CYB 1931, Nendeln Liechtenstein Kraus Reprint, 1972, 'Appendix IV Financial Statement for 1929-30', p. 702 .

42 Ibid.

43 E. Kann, 'Chinese Government Loans', CYB 1934, p. 547.

44 Cain and Hopkins, British Imperialism; Crisis and Deconstruction, p. 250.

45 Endicott, p. 21; Rawski, p. 31.

46 Figures are drawn from the Ministry of Finance's 'General Statement of Cash Receipts and Payments' provided in the CYB 1931, pp. 698-9; CYB 1932, pp. 434-5; CYB 1934, pp. 492-4; and CYB 1936, pp. 385-6. 
47 CYB 1934, p. 492.

48 CYB 1931, pp. 698-9; CYB 1932, pp. 434-5; CYB 1934, pp. 492-4; and $C Y B$ 1936, pp. 385-6.

49 Endicott, p. 21.

50 Ibid. Endicott discusses that military and loan expenditure accounted for 80 per cent of total expenditure.

51 Wright, Collection and Disposal, pp. 70-1.

52 E. Kann, 'Internal Loan Issues Outstanding on Jan 1 1934', CYB 1934, pp. 558-60.

53 CYB 1934, p. 497.

54 Wright, Collection and Disposal, p. 35.

55 Robert Campbell writing about his father's service as NRS in the LO in Robert Ronald Campbell, James Duncan Campbell: A Memoir by His Son, Cambridge: Harvard East Asian Monographs, 1970, p. 19.

56 An important source for examining the LO and its relationship with the Service in China is the correspondence between the IG and the NRS known as the ' $\mathrm{Z}$ Series Letters'. The ' $Z$ Series' was intended to enable a free discussion of matters that could not have been properly addressed in semi-official correspondence. See: Francis Aglen, letters to Guy Acheson and Cecil Bowra, 7 Jan. 1921-23 Dec. 1924, Letter Series Z, Library of the School of Oriental and African Studies, London; Francis Aglen, confidential correspondences with Guy Acheson and Cecil Bowra, 2 Jan. 1921-7 June 1926, Letter Series Z, Library of the School of Oriental and African Studies, London.

57 Hart had appointed von Grumpach as professor of mathematics and astronomy at the new college in Beijing. However after his dismissal by Hart on the grounds of unsuitability for the position, von Grumpach took Hart to the Shanghai court on grounds of wrongful dismissal and won. Campbell was integral in arranging the challenging of this ruling in the Privy Council. The success of this challenge established the IG as not responsible to British courts when acting lawfully as a Chinese employee. Wright devoted Chapter XII to this case and introduces von Grumpach: 'he turned out to be not an instructor but a litigious obstructionist and a seeker of notoriety'. S.F. Wright, Hart and the Chinese Customs, Belfast: W. Mullan, 1956, p. 238. For a brief review of Campbell's role see Campbell, James Duncan Campbell, p. 17.

58 Robert Hart, 31 Aug. 1873, letter 63 of The I.G. in Peking: Letters of Robert Hart, Chinese Maritime Customs 1868-1907, eds John King Fairbank, Katherine Frost Bruner and Elizabeth MacLeod Matheson, vol. 1 Cambridge: Belknap Press, 1975, p. 122.

59 Hart, 20 Jan. 1874, letter 76 of The I.G. in Peking, vol. 1, p. 142.

60 Hart writes, 'we are being so hard put to it that the question of the existence of the L.O. again is likely to come up: as it is, anybody here would volunteer to go there for half your pay and everybody is growling over gold being paid to men in London while in China they only get silver. Of course I know what a valuable man you are and how well you work, but economy may force another I.G. to bring you to a port in China and reduce expenditure - if not stop it altogether - in London.' Hart, 29 Jan. 1894, letter 918 of The I.G. in Peking, vol. 2, pp. 960-2.

61 See Cecil Bowra, letter to F.A. Aglen, 17 June 1924, Letter Series Z; and F.A. Aglen, letter to Cecil Bowra, 27 May 1924, Letter Series Z.

62 Aglen, letter to Bowra, 27 May 1924, Letter Series Z.

63 Aglen, letter to Bowra, 11 Mar. 1924, Letter Series Z.

64 Bowra, letter to Aglen, 17 June 1924, Letter Series Z.

65 Ibid.

66 M.O. Law, confidential and private report to F.W. Maze, c.1930, The Maze Collection, National Maritime Museum, Greenwich. 
67 Ibid. Law writes: 'The London Office house is a very old one with no very modern up-to-date conveniences but it is in a very desirable part of London and no man could think it undesirable to live in the house or district.'

68 Wright, Hart and the Chinese Customs, p. 401. This representation of China by the Western dominated Customs may be attributed to the trend of Orientalism, the creating of images of the exotic other as discussed by Edward Said.

69 Ibid., p. 517.

70 Campbell, James Duncan Campbell, pp. 28-9.

71 Aglen, letter to Bowra, 4 Mar. 1924, Letter Series Z.

72 Cecil A.V. Bowra, Memoirs of C.A.V. Bowra, 1920-1932, ms., Manuscripts Collection, Library of the School of Oriental and African Studies, London, p. 438.

73 Aglen, letter to Bowra, 21 Apr. 1924, Letter Series Z.

74 Aglen writes, 'I hope those Members of Parliament will go on asking questions and holding China before the public gaze. All that does good out here. If you see Looker you might give him a hint.' Aglen, letter to Bowra, 20 Apr. 1926, Letter Series Z

75 C. Macoun, letter to Frederick Maze, 29 Dec. 1933, The Papers of Sir Frederick Maze relating to the Chinese Maritime Customs Service, vol. 9, unpublished, Library of the School of Oriental and African Studies, London, p. 393. This group of documents will be known subsequently as the Maze Papers.

76 See Frederick Maze, letter to Stephenson, 29 Sept. 1930, The Maze Papers, vol. 5 , p. 120.

77 For a discussion on the basic concepts behind the use of stereotypes see Richard Dyer, The Matter of Images: Essays on Representations, London: Routledge, 1993, pp. 11-18.

78 F.A. Aglen, semi-official circular no. 36, 23 Jan. 1923, Documents, vol. 3 Shanghai, Statistical Department of the Inspectorate General of Customs, 1938, pp. 682-3.

79 'Tidewaiters Confidential Report', Chinese Maritime Customs, pp. 29-31.

80 See for example Acheson, letter to Aglen, 25 Jan. 1923, Letter Series Z; Bowra, letter to Aglen, 27 Mar. 1924, Letter Series Z.

81 Chinese Maritime Customs Service, The Origin and Organisation of the Chinese Customs Service, p. 23.

82 Ibid.

83 Acheson, letter to Aglen, 1 Apr. 1921, Letter Series Z.

84 Acheson, letter to Aglen, 7 Jan, 1921, Letter Series Z.

85 Chinese Maritime Customs Service, The Origin and Organisation of the Chinese Customs Service, pp. 23-9.

86 Ibid., p. 24.

87 Examples include H.B. Morse, S.F. Wright, B. Lenox Simpson ('Putnam Weale') and G.R.G. Worcester among others.

88 Campbell, James Duncan Campbell, p. 34. Lunches were held at the Thatched House Club in Saint James's street.

89 King, personal interview.

90 Ralph Nevill, London Clubs: Their History and Treasures, London: Chatto and Windus, 1911, pp. 132-4.

91 Aitchison, 'The Chinese Maritime Customs Service', p. 102.

92 Discussed in Cain and Hopkins, British Imperialism: Innovation and Expansion 1688-1914, London, Longman, 1993, p. 439.

93 Frank H.H. King, The Hongkong Bank in the Period of Imperialism and War, 1895-1918: Wayfoong, the Focus of Wealth, vol. 2 of History of the Hongkong and Shanghai Banking Corporation, New York: Cambridge University Press, 1988, pp. 188-90. 
94 Chinese Maritime Customs Service, The Origin and Organisation of the Customs Service, pp. 26-7. The ranks and rates of pay are given in detail. Candidates were employed as 4th Assistant B at a salary of $150 \mathrm{Hk}$.Tls a month. The exchange rate for the $\mathrm{Hk} . \mathrm{Tl}$ in 1921 was 3 shillings and 117/16 pence.

95 Ibid., pp. 23-4.

96 Ibid., p. 27.

97 King, The Hongkong Bank in the Period of Imperialism and War, p. 153.

98 Acheson, letter to Aglen, 4 Mar. 1921, Letter Series Z.

99 All About Shanghai and Environs: A Standard Guide Book, Shanghai: The University Press, 1934.

100 Robert Bickers, Britain in China: Community, Culture and Colonialism 1900-1949, Manchester: Manchester University Press, 1999, p. 85.

101 Chinese Maritime Customs Service, The Origin and Organisation of the Customs Service, p. 25.

102 Rasmussen, Chinese Trader, pp. 14-15.

103 Campbell, James Duncan Campbell, pp. 79-80. Campbell's son, James Ballie, was appointed to the Peking Inspectorate in early 1892 but was struck down by typhoid fever and died within a year of leaving England.

104 Aglen, letter to Bowra, 11 Mar. 1924, Letter Series Z. Instances of employees being afflicted with illness are also evident in Aglen's letters to Bowra of 25 Mar. 1924 and 15 Apr. 1924.

105 A.H.F. Edwardes, semi-official circular 54, 24 Feb. 1927, Documents, vol. 4, pp. 126-7.

106 F.W. Maze, circular 3873, 14 March 1929, Documents, vol. 4, pp. 174-90. See also 'Enclosure No. 2 English version of resolution approved by the Ministry of Finance', Documents, vol. 4, p. 187.

107 Much of this personal information is drawn from Yvonne King's memoir, 'A Variegated Life', unpublished ts., c.1990. Other detail is from a personal interview with Mrs King at her Box Hill home in Victoria on 26 July 1998.

108 King, 'A Variegated Life', p. 19.

109 Anthony Hewitt, Children of the Empire, Kenthurst: Kangaroo Press, 1995, p. 22. Anthony's wife Elizabeth was the daughter of Lieutenant Colonel Hayley Bell, Commissioner in the CMCS.

110 Longzhou 1913, St Servan 1914-17, Qinhuangdao 1917-20, St Servan 1920-1,Verneuil s/Avre 1921-2, Shanghai 1922, Macao 1922-3, Paris 1923-5, Macao 1926, Beijing 1926-8, Zhifu 1928-30, Hankou 1930-3, Shanghai 1933-6, England 1936-7, Weihaiwei 1937-9, Shanghai 1939-43, 'Lungwha Civilian Internment Camp' 1943-5, Qingdao 1945-6, England 1946-8, Saigon February 1948, Guangzhou 1948, Xiamen 1948-9, Hong Kong 1949-50. Adapted from the index of King's, 'A Variegated Life'.

111 Perry Anderson, 'A Belated Encounter: Perry Anderson retraces his father's career in the Chinese Customs Service', London Review of Books, 30 July 1998: pp. 5-10; 20 Aug. 1998: pp. 28-34.

112 Christopher Briggs, MBE Hai Kuan: The Sea Gate, Cheshire: Lane, 1997, p. 102.

113 Yvonne King's daughter, Sally, was born in Shanghai (c.1933). Her son, Richard, was born in Weihaiwei (c.1937-38). At the time of her second pregnancy, however, the Sino-Japanese War had broken out and Yvonne could not return to Shanghai for the birth. While there were no medical facilities available for Yvonne, she felt fortunate her son was delivered by a doctor of the British Navy who was stationed just off Weihaiwei. King, 'A Variegated Life', pp. 76-7.

114 Briggs, Hai Kuan, p. 100.

115 King, 'A Variegated Life', p. 71. 
116 This terminology referred to the male servant entrusted with running the dayto-day aspects of the household, budgeting for groceries and supervising the other servants. Having a responsible and trustworthy boy was essential to the smooth running of any foreign household in China.

117 King, 'A Variegated Life', p. 71.

118 Ibid., pp. 5-6.

119 Ibid., p. 22.

120 Ibid.

121 See Williams, Chinese Tribute, p. 62 and Hewitt, Children of the Empire, pp. 34-7. These accounts both deal with the fact that children were sent home to be educated rather than remaining in China with their parents.

122 King, 'A Variegated Life', p. 34.

123 Anderson 'A Belated Encounter' p. 7.

124 King, In the Chinese Customs Service, p. 18.

125 Christopher New, Shanghai: A Novel, London: Macdonald and Co, 1985.

126 Briggs, Hai Kuan, p. 85. Briggs is candid regarding his desire to try to cling to his bachelor ways, despite his wife and young daughter's arrival in China.

127 King, 'A Variegated Life', pp. 34-5; Williams, Chinese Tribute, p. 58.

128 King, 'A Variegated Life', pp. 34-5.

129 Hewitt, Children of the Empire, p. 23; King, 'A Variegated Life', pp. 46-7; and Williams, Chinese Tribute, pp. 129-42.

130 Briggs discusses this in his memoirs and the way that renting the houses or flats of those on leave was a common practice. Briggs Hai Kuan, p. 99.

131 Ibid.

132 King, 'A Variegated Life', p. 41.

133 Anderson, 'A Belated Encounter', p. 29.

134 King, 'A Variegated Life', p. 29.

135 The Killearn Diaries, the diaries of Sir Miles Wedderburn Lampson First Baron Killearn. Customs people listed among guests at a dinner party, 20 Nov. 1929. Other references include 15 Nov. 1927 and 12 May 1930.

136 Willams, Chinese Tribute, p. 78.

137 Ibid., p. 64.

138 Anderson, 'A Belated Encounter', p. 30.

139 Briggs, Hai Kuan, p. 87.

140 King, personal interview.

141 Briggs, Hai Kuan, p. 98.

142 Ibid., p. 102.

143 Bickers cites the marriage register for Tainjin for 1919-30s, which indicated a large proportion of marriages to Russians and Eurasians being with Customs officers. Bickers, Britain in China, p. 99.

144 Ibid., p. 78. While this is based on hearsay, it is noteworthy that Briggs recalls such an incident and that it made a lasting impression on him in relation to how the Eurasian community or mixed marriages were viewed within the treaty

145 Ibid. port community.

146 Hewitt, Children of the Empire, p. 23.

147 King, personal interview.

148 Williams, Chinese Tribute, p. 52.

149 Ibid., p. 58.

150 King, personal interview.

\section{Gunboats and revenue, $1923-7$}

1 When referring to the diplomatic body, I am using a self-appointed title the foreign powers adopted to describe their representatives in China. 
2 After occupying Guangzhou in 1920, Chen was appointed by Sun to the position of governor of Guangdong. Chen was a progressive leader, implementing educational and administrative reforms and offering patronage to various intellectuals. Chen's ambitions for his leadership in Guangdong, however, came into increasing conflict with Sun's aims for his movement. He was reluctant (as commander-in-chief of the Guangdong Army) to use his forces as the base for challenging the forces of Wu Peifu and to fulfil Sun's aim for a Northern expedition. In early 1922 Chen withdrew his support from Sun and resigned his position. In the following months his troops attacked and overthrew Sun, forcing him to flee to Shanghai. See Howard L. Boorman and Richard C. Howard, eds, Biographical Dictionary of Republican China, vol. 1, New York: Columbia University Press, 1967-79, pp. 173-80; CYB 1924, 'Who's Who', p. 983.

3 Sidney H. Chang and Leonard H.D. Gordon, All Under Heaven .. . Sun Yat-sen and His Revolutionary Thought, Stanford: Hoover Institution Press, 1991, p. 74.

4 Lyon Sharman, Sun Yat-sen, His Life and Meaning: A Critical Biography, Stanford: Stanford University Press, 1934, p. 249. In this early biography of Sun, particular significance is attached to Sun choosing to become Generalissimo, as he then also controlled the military and therefore safeguarded his position.

5 C. Martin Wilbur, 'The Nationalist Revolution: From Canton to Nanking, 1923-28', Republican China 1912-1949, vol. 12, part 1 of The Cambridge History of China, ed. John King Fairbank, New York: Cambridge University Press, 1983, p. 528. For a more detailed treatment of this era see C. Martin Wilbur, The Nationalist Revolution in China, 1923-1928, Cambridge: Cambridge University Press, 1984.

6 The premise that Sun sought access to the Customs to ensure his political survival is commonly agreed in academic treatments of this controversy. For examples see C. Martin Wilbur, 'The Nationalist Revolution'; Roberta A. Dayer, Bankers and Diplomats in Republican China, London: Frank Cass and Company, 1981, chapter 5; and Chang and Gordon, All Under Heaven, pp. 80-1.

7 Gilbert Chan 'An Alternative to Kuomintang-Communist Collaboration: Sun Yat-sen and Hong Kong, January-June 1923' Modern Asian Studies, 13.1 (1979): $133-5$.

8 Ibid., p. 137.

9 CYB 1924, p. 751.

10 Ibid.

11 Chao-Chu Wu, letter to James Jamieson, 5 Sept. 1923, Documents Illustrative of the Origin, Development, and Activities of the Chinese Customs Service, vol. 7 Shanghai: Statistical Department of the Inspectorate General of Customs, 1940, p. 295. This series will subsequently be referred to as Documents.

12 R. Macleay, letter to C.C. Wu, 3 Dec. 1923, document 107 in Ann Trotter, ed., British Documents on Foreign Affairs: Reports and Papers from the Foreign Office Confidential Print, part 2, series E, vol. 28 Frederick: University Publications of America, 1984, pp. 144-5. This series title will be subsequently abbreviated as British Documents and all references to this title refer to part 2, series E. This series is a republished version of series FO 405 'Further Correspondence'.

13 Wilbur, 'The Nationalist Revolution', p. 530.

14 Chang and Gordon, All Under Heaven, p. 80.

15 Chinese Maritime Customs Service, Customs Annual Report for 1923, Shanghai: Statistical Department of the Inspectorate General of Customs, 1924.

16 Macleay, letter to C.C. Wu, 3 Dec. 1923, document 107 of British Documents, vol. 28 , pp. 144-5. 
17 Macleay, letter to the Marquess Curzon of Kedleston, 21 Dec. 1923, document 105 of British Documents, vol. 28, p. 137.

18 Sun Yatsen, 'Dr. Sun Yat-sen's Statement', 19 Dec. 1923, Documents, vol. 7, pp. 309-12.

19 R. Macleay, letter to the Marquess Curzon of Kedleston, 21 Dec. 1923, document 105 of British Documents, vol. 28, pp. 137-9.

20 Macleay, letter to C.C. Wu, 3 Dec. 1923, document 107 of British Documents, vol. 28 , pp. $144-5$.

21 Ibid. The powers referred to in the letter are not the Westerners working within the CMCS but rather the treaty powers.

22 'Customs issue at Canton', NCDN, 18 December 1923.

23 'America and the Canton Crux. US. Feeling Alarmed by the Report of AntiAmerican Sentiment Due to Customs Question', NCDN, 31 December 1923.

24 Chan, Lau Kit-ching, 'The Lincheng Incident: a Case Study of British Policy in China Between the Washington Conference (1921-1922) and the Nationalists Revolution (1925-1928)', Journal of Oriental Studies, July 1972, 10.2: 172.

25 Macleay, 'Annual Report, 1923', document 9 of British Documents, vol. 19, p. 189.

26 See Dayer, Bankers and Diplomats, p. 164. In her work on finance imperialism, Dayer examined the Lincheng incident and the Guangzhou Customs as two examples of Western interference in Chinese affairs. In doing so Dayer interpreted the powers' reaction to the Customs incident as being directly influenced by this incident.

27 'A New Policy Needed in China', editorial, NCDN, 14 Dec. 1923.

28 'International Issues', $C Y B$ 1924, pp. 818-29.

29 Ibid., pp. 822-3.

30 W.J. Oudendijk, telegram and dispatch to Sir James Jamieson Senior Consul Canton), 12 Dec. 1923, Documents, vol. 7, p. 307.

31 See James Cable, Gunboat Diplomacy: Political Applications of Limited Naval Force, London: Chatto \& Windus, 1971, pp. 15-22.

32 Ibid., p. 17

33 'An Interview with Dr Sun Yat-sen', NCDN, 6 Dec. 1923.

34 Ibid.

35 Ibid., Also, 'Sun Yat-sen's Threat. Canton Customs to be Seized: Russian Alliance Hinted At', The Times, London, 6 Dec. 1923.

36 Macleay, to Marquess Curzon of Kedleston, 13 Mar. 1924, document 105 of British Documents, vol. 28, p. 137.

37 'The Customs Issue At Canton', NCDN, 18 Dec. 1923.

38 'A New Policy Needed in China', editorial, NCDN, 14 Dec. 1923.

39 'China Trampling on Treaties. Why They Were Made and How She Might Be Rid of Them Without Offence. Students the dupes of subtle politicians', NCDN, 24 Dec. 1923.

40 To focus on the sense of British duty in China leads to a discussion of the use of the civilizing mission as a discourse for justifying imperialism. Such comments hark directly to Kipling's urging the US (and indirectly all Western nations) to shoulder the responsibility of 'The White Man's Burden' in bringing modernization and Westernization to the world. This poem has become readily recognized as a touch point for postcolonial, literary thinkers, including Edward Said and Homi Bhabha as they often refer to the 'civilizing mission' of the Western powers.

41 For a further discussion of the $N C D N$ see the introduction to the NCDN microform reels, 17 Dec. 1921; Sept.-Oct. 1923, ii. Also see Frank H.H. King and Prescott Clarke, eds, A Research Guide to China Coast Newspapers, 1822-1911, Cambridge: East Asian Research Center, Harvard University Press, 1965 , pp. 28-31. 
42 Rodney Gilbert, What's Wrong With China, New York: Frederick A. Stokes, 1926, p. 45.

43 Ibid., pp. 80-1.

44 John T. Pratt, War and Politics in China, London: Jonathan Cape, 1943, p. 200.

45 Chan Lau Kit-ching, 'The Lincheng Incident', p. 173.

46 Customs documents are sparse in their coverage of this controversy, so too the Annual Customs report for 1923. The volumes of CMCS documents, yielded few items that discussed this affair. Furthermore, S.F. Wright's The Collection and Disposal of the Maritime and Native Customs Revenue Since the Revolution of 1911, Shanghai: Statistical Department of the Inspectorate General of Customs, 1927, which is meticulously detailed in its coverage of the CMCS, dealt with this incident quite briefly and oversimplified the implications of Sun's claims. Wright treated it as another 'hiccup' in the history of the Service and failed to impart any sense of the actual significance of this event (Wright, p. 187).

47 Charles Drage, Servants of the Dragon Throne: Being the Lives of Edward and Cecil Bowra, London: Peter Dawnay, 1966, p. 272.

48 CYB 1923, pp. 1031-7. Harris was central to the early negotiations surrounding the Hong Kong-China Trade and Customs Agreement in 1910. See chapter 6.

49 Cecil A.V. Bowra, letter to Commissioner of Customs, Canton, 9 Oct. 1923, Documents, vol. 7, p. 303.

50 Francis Aglen, letter to Guy Acheson, 10 Dec. 1923, Letter Series Z, Library of the School of Oriental and African Studies, London.

51 Aglen, letter to Cecil Bowra, 16 Feb. 1924, Letter Series Z.

52 See Dayer; Chan Lau Kit-ching, 'The Lincheng Incident'.

53 R. Macleay, Annual Report, 1923', British Documents, vol. 19, pp. 171-2.

54 'Sun Yat-sen's Threat', The Times, 6 Dec. 1923.

55 'The Controversy at Canton', NCDN, 29 Dec. 1923.

56 Aglen, letter to Bowra, 21 Aug. 1924, Letter Series Z.

57 For definitions of gunboat diplomacy and the context for its use see Cable, Gunboat Diplomacy, Anthony Preston and John Major, Send A Gunboat!: A Study of the Gunboat and its Role in British Policy, 1854-1904, London: Longmans, 1967.

58 Aglen, letter to Bowra, 20 Nov. 1925, Letter Series Z.

59 In his work on Awakening China, Fitzgerald discusses the innate skill possessed by Sun in a time when not only a military struggle was waging but a struggle to create and claim icons of the new Chinese nation. Fitzgerald reflects that while Sun had started his life as an iconographer, by the time of his death he had become an icon of the nationalist cause. Sun's use of symbolism in the Guangzhou Customs controversy is an example of the skills Fitzgerald explores in his work. See John Fitzgerald, Awakening China: Politics, Culture, and Class in the Nationalist Revolution, Stanford: Stanford University Press, 1996, p. 26.

60 Edmund S.K. Fung, 'The Chinese Nationalists and the Unequal Treaties 1924-1931', Modern Asian Studies, 21.4 (1987): 800. Fung gives a good discussion of the development of Sun's ideas of imperialism after 1923. See also C. Martin Wilbur, Sun Yat-sen: Frustrated Patriot, New York, Columbia University Press, 1976, pp. 197-207.

61 Fung, 'The Chinese Nationalists', p. 799.

62 Sun's doctrine was developed throughout his life as a revolutionary but had never been written in the form of a political philosophy for the GMD. The Three Principles of the People were first articulated by Sun in a series of lectures to students and GMD followers in 1924. After Sun's death, his doctrines became virtually a GMD bible for Nationalist China. Sun Yatsen, San Min Chu I: The Three Principles of the People, trans. F.W. Chen, ed. L.T. Chen Calcutta: Chinese Ministry of Information, 1942. 


\section{Notes}

63 Kuang-Sheng Liao, Antiforeignism and Modernization in China, 2nd ed. Hong Kong: Chinese University Press, 1986, pp. 11-13.

64 Zhongguo Guomindang dangshi weiyuan hui (ed.), Geming wenxian, LXIX, 92-3. Quoted and translated in Fung, 'Chinese Nationalists', p. 799.

65 Ibid.

66 Fung, 'The Chinese Nationalists', p. 800. Fung points out, however, that even though this point appeared radical, it still offered the possibility of renegotiating the treaties.

67 Military Governor of a Province.

68 Miles Lampson, 'Annual Report, 1926', British Documents, vol. 19, p. 419.

69 Ronald Macleay, 'Annual Report, 1925', British Documents, vol. 19, pp. 313-14.

70 Ibid., pp. 314-15.

71 Richard Rigby, The May 30 Movement: Events and Themes, Canberra: Australian National University Press, 1980, p. 63.

72 Ibid., pp. 63-4. From the outset of his work, Rigby clarifies his reasoning for not discussing the Guangzhou-Hong Kong boycott as part of this movement and in doing so notes that this is in keeping with the practice of most CCP historians. See Rigby viii.

73 Macleay, 'Annual Report, 1925', p. 316.

74 'Bomb-throwing in Hongkong', NCDN, 11 July 1925; 'Rising Tide in Swatow: Serious Situation: A General Strike: Outrages on Missionaries', and 'Shameen Again Threatened: Rumours of Another Attack', NCDN, 13 July 1925; 'The Hankow Riot', NCDN, 14 July 1925, 'Strike at Swatow', NCDN, 16 July 1925, 'British Evacuated From Wuchow', NCDN, 22 July 1925.

75 'Chinese Making Poison Gas', NCDN, 16 July 1925.

76 'Will Britain Stand Alone?' NCDN, 3 July 1925.

77 Macleay, 'Annual Report, 1925', pp. 322-3.

78 Ibid. An international defence scheme was put into action. There were landing parties of British, Italian, French and American troops from warships in the port.

79 Putnam Weale, Why China Sees Red, London: Macmillan, 1926.

80 Lee En-han, 'China's Recovery of the British Hankow and Kiukiang Concessions in 1927', Occasional Paper no. 6 Nedlands: University of Western Australia; Centre for East Asian Studies, 1980, pp. 1-34.

81 W. Russel Brown to Lampson, 'Enclosure no. 2 in Hankow Despatch No 41 of 13/5/1981 to H.M. Minister, Peking', F0371/13466.

82 Chan Lau Kit-ching, China, Britain and Hong Kong 1895-1945, Hong Kong: Chinese University Press, 1990, p. 177.

83 Ibid. pp. 177-80.

84 Schjoth, 'Closing of the Customs House, Mr. Schjoth's Account of Incident', 27 Mar. 1929, The Papers of Sir Frederick Maze relating to the Chinese Maritime Customs Service, vol. 18, unpublished, Library of the School of Oriental and African Studies, London. This group of documents will be subsequently referred to as the Maze Papers.

85 This was without permission from the Chinese and later surfaced as a large part of GMD criticism of Edwardes when he was nominated for the position of IG in 1928.

86 Schjoth, 'Closing of the Customs House'.

87 Ibid.

88 Macleay, 'Annual Report, 1925', p. 328.

89 Ibid., pp. 328-9.

90 'Bolshevik Plot to Make Shameen Fire Upon Women', NCDN, 29 July 1925.

91 Fung, 'Chinese Nationalists and the Unequal Treaties 1924-1931', pp. 804-5.

92 Macleay, 'Annual Report, 1925', p. 329.

93 Chan Lau, China, Britain and Hong Kong, p. 194. 
94 Schjoth, 'Closing of the Customs House'.

95 Francis Aglen, 'Inspector General: Sir Francis Aglen, Inspector General, resumes charge of Customs Service; Inspector General's appreciation of conduct of Staff during period of unusual stress and difficulty',16 Nov. 1925, Documents, vol. 4 , pp. 87-8.

96 Schjoth, 'Closing of the Customs House'.

97 Ibid.

98 Ibid.

99 Anthony Hewitt, Children of the Empire, Kenthurst: Kangaroo Press, 1993, p. 25.

100 Hewitt provides a photo of Bell in his military garb.

101 Recounted in Hewitt, Children of the Empire, p. 26.

102 Schjoth, 'Closing of the Customs House'.

103 Yvonne King, personal interview, 26 July 1998. Mrs King comments that she thought that Bell's actions in wearing the uniform had culminated in his dismissal but this was not actually the case.

104 F0405/250 Enclosure 1 in No 125. Jamieson

105 Cecil Clementi, letter to Amery, 24 Feb. 1926, The Clementi Papers, Rhodes House Library, Oxford.

106 'Lieut.-Col Hayley Bell Assaulted', NCDN, 24 Apr. 1926.

107 'The Assault on Lieut. Col. Hayley Bell', NCDN, 29 Apr. 1926.

108 Retold by Hewitt, Children of the Empire, p. 26.

109 Ibid.

110 Hewitt writes of a lasting friendship that had developed between Clementi and Bell: 'Both men were sinologists with a deep love of China and both were speakers of Mandarin and Cantonese. Hayley Bell's wide knowledge of China was of value to Clementi and they held similar opinions on the future of the Colony and Empire: that European dominance in China was declining but that the British would never relinquish Hong Kong' (Hewitt, Children of the Empire, p. 27). Within The Clementi Papers there are several personal letters from Bell, a reflection of their rapport.

111 Hayley Bell, letter to Cecil Clementi, 26 Apr. 1926, The Clementi Papers.

112 Hayley Bell, letter to Cecil Clementi, 29 June1926, The Clementi Papers.

113 Ibid. The Tung-yuan was the Strike Committee headquarters in Canton, there were also eight local offices. Chan Lau, China, Britain and Hong Kong, p. 182.

114 Bell, letter to Clementi, 29 June 1926,

115 Hayley Bell, letter to Eugene Chen, 9 June 1926, The Clementi Papers.

116 Francis Aglen, letter to Cecil Bowra, 20 Nov. 1925, Letter Series Z.

117 Aglen was absent for the summer of 1925 and only resumed his post in November. He wrote, 'I greatly regret my absence from my post coincided with a period of more than usual stress and difficulty and that I was not here to share with the Service the anxieties of the past summer'. He had another absence of leave between 25 June and 10 November 1926 and during this time Edwardes was the Acting IG. Francis Aglen, 'Inspector General: Sir Francis Aglen, Inspector General, resumes charge of Customs Service', pp. 87-8. Also A.H.F. Edwardes, 'Customs allowance: Increased grant from 1st July 1926 notified; revised port allowances to be appropriated monthly from revenue; instructions', 2 July 1926, Documents, vol. 4, pp. 96-7.

118 Drage, Servants of the Dragon Throne, pp. 272-3.

119 Francis Aglen, 'Situation in China as Affecting Customs Service: Inspector General's Observations and Advice', 15 Dec. 1926, Documents, vol. 4, pp. 113-16.

120 Miles Lampson, telegram to Consul General of Canton, 31 Jan. 1927, The Clementi Papers. 


\section{Notes}

121 J.F. Brenan, letter to R. Macleay, 26 July 1926, document 57 of British Documents, vol. 31, p. 97.

122 NCDN, 3 July 1925 and 2 Apr. 1926 respectively.

123 J.F. Brenan, letter to R. Macleay, 20 July 1926, document 47 of British Documents, vol. 31, p. 81.

124 W. Tyrrell, telegram to R. Macleay, 17 Sept. 1926, document 76 of British Documents, vol. 31, p. 112.

125 E. Howard, letter to Austen Chamberlain, 11 Sept. 1926, document 94 of British Documents, vol. 31, p. 127.

126 Macleay, 'Annual Report, 1925', p. 330.

127 J.F. Brenan, telegram to Austen Chamberlain, 18 Sept. 1926, document 79 of British Documents, vol. 31, p. 114.

128 J.T. Pratt, 'The Customs Administration and the New Taxation Proposals at Canton', 29 Sept. 1926, document 102 of British Documents, vol. 31, p. 132.

\section{Nationalist ascendancy and the politics of being Inspector General}

1 Miles Lampson, letter to Cecil Clementi, 7 Feb. 1927, The Clementi Papers, Rhodes House Library, Oxford.

2 Francis Aglen, letter to Cecil Bowra, 7 Apr. 1926, Letter Series Z, Library of the School of Oriental and African Studies, London.

3 Ibid.

4 Ibid.

5 Miles Lampson, telegram to Consul General Canton, 28 Jan. 1927, The Clementi Papers.

6 Ibid.

7 Miles Lampson, telegram to Consul General Canton, 30 Jan. 1927, The Clementi Papers.

8 Francis Aglen, semi-official circular no. 53, 11 Feb. 1927, Documents Illustrative of the Origin, Development, and Activities of the Chinese Customs Service, vol. 4, Shanghai: The Statistical Department of the Inspectorate General of Customs, 1939, p. 121. This series will subsequently be referred to as Documents.

9 Aglen, semi-official circular no. 53, 11 Feb. 1927.

10 Lampson, telegram, 30 Jan. 1927, The Clementi Papers.

11 Miles Lampson, 25 Feb. 1927, The Killearn Diaries: Being the Diaries of Sir Miles Wedderburn Lampson, vol. 1, ms., St Antony's College Middle East Centre, University of Oxford.

12 Lampson, 17 Mar. 1927, The Killearn Diaries, vol. 1.

13 Miles Lampson, telegram to Consul General Canton, 2 Feb. 1927, The Clementi Papers.

14 Ibid.

15 Miles Lampson, 'Annual Report, 1928', British Documents on Foreign Affairs: Reports and Papers from the Foreign Office Confidential Print, part 2, series E, vol. 20, Frederick: University Publications of America, 1984, p. 60. This series title will be subsequently abbreviated as British Documents and all references to this title refer to part 2, series E.

16 Jean Aitchison, 'The Chinese Maritime Customs Service in the Transition from the Ch'ing to the Nationalist Era', diss., School of Oriental and African Studies, London University, 1983, pp. 470-516.

17 Martyn Atkins, Informal Empire in Crisis: British Diplomacy and the Chinese Customs Succession, 1927-1929, Ithaca: East Asia Program Cornell University, 1995. 
18 Lloyd Eastman, J. Ch'en, S. Pepper and L. Van Slyke, Nationalist Era in China, 1927-1949, New York: Cambridge University Press, 1991, p. 9. The most detailed account of Zhang's Beijing regime can be found in Gavan McCormack, Chang Tso-lin in Northeast China, 1911-1928: China, Japan and the Manchurian Idea, Stanford: Stanford University Press, 1977, pp. 188-249.

19 Lampson, 1 June 1928, The Killearn Diaries.

20 Aitchison, 'The Chinese Maritime Customs Service', pp. 473-4.

21 Nicholas R. Clifford, Retreat from China: British Policy in the Far East, 1937-1941, London: Longmans, 1967, p. 6.

22 See Clifford, Retreat from China, Edmund Fung, The Diplomacy of Imperial Retreat: Britain's South China Policy, 1924-1931, New York: Oxford University Press, 1991, and Wm. Roger Louis, British Strategy in the Far East 1919-1939, Oxford: Clarendon Press, 1971.

23 Miles Lampson, 'Annual Report, 1927', British Documents, vol. 20, pp. 32-3. See also Louis, pp. 132-3.

24 Atkins, Informal Empire in Crisis, p. 21.

25 'The Attack on Mr Johnston', editorial, NCDN, 9 Oct. 1928. Also see leading article 'The Assault on Mr Johnston. Nanking Commissioner of Customs Brutally Beaten and Left Unconscious. NO ATTEMPT TO PUNISH THE ASSAILANTS', NCDN, 9 Oct. 1928.

26 Meyrick Hewlett, Forty Years in China, London: Macmillan, 1943, p. 212.

27 Ibid.

28 Atkins, Informal Empire in Crisis, p. 21. Atkins deals with this incident briefly, including it within a chapter that discusses the British official attitude to the emergence of the Nationalists, 'Whitehall's Response to Chinese Nationalism'.

29 Miles Lampson, telegram to Austen Chamberlain, 16 Mar. 1928, document 294 of British Documents, vol. 34, p. 248.

30 Francis Aglen, circular no. 3749 (second series), 11 Feb. 1927, Documents, vol. 4, p. 117.

31 Lampson, 25 Feb. 1927, The Killearn Diaries.

32 Lampson, 17 Mar. 1927, The Killearn Diaries.

33 Miles Lampson, telegram to Cecil Clementi, 9 Feb. 1927, The Clementi Papers.

34 Miles Lampson, letter to Austen Chamberlain, 13 July 1927, document 125 of British Documents, vol. 33, p. 152.

35 Lampson, letter to Chamberlain, 13 July 1927, p. 153.

36 Miles Lampson, telegram to Cecil Clementi, 7 Feb. 1927, The Clementi Papers.

37 Aitchison, 'The Chinese Maritime Customs Service', p. 472.

38 In the Clementi Papers dealing with Aglen's dismissal there is mention of the Acting IG (Edwardes) dining with Lampson and he was also in contact with him regarding the threats to dismiss Aglen. See Lampson, telegram, 28 Jan. 1927, The Clementi Papers.

39 Lampson, 15 Nov. 1927, The Killearn Diaries.

40 Miles Lampson, letter to Austen Chamberlain, 4 Jan. 1928, document 6 of British Documents, vol. 34, p. 3.

41 Edwardes contacted Lampson regularly for advice and to discuss the Customs situation. See the various entries of Lampson's Killearn Diaries on 27 Aug. and 18 Nov. 1927; 3, 4, 19 Jan.; 29 Mar. and 4 Oct. 1928 as examples of Edwardes' close relationship with Lampson.

42 Lampson, 4 Jan. 1928, The Killearn Diaries. Lampson mentions the Japanese and their desire to preserve the Customs Service.

43 Miles Lampson, telegram to Austen Chamberlain, 11 Jan. 1928, document 19 of British Documents, vol. 34, p. 10. This was an account of the objections raised against Edwardes that Maze gave to S. Barton. The head of the revenue 
council, Fu Bingxiang, had been the superintendent of Customs in Guangzhou at the time of Edwardes' alleged closing of the Customs house. Maze commented of $\mathrm{Fu}$, 'he is naturally unfavourable to Edwardes'. See also 'Abstract from Chinese Newspapers of the 3rd August 1928', Maze Papers, vol. 2, pp. 187-9 and You Feibeng, letter to Frederick Maze, 13 Aug. 1928, The Papers of Sir Frederick Maze relating to the Chinese Maritime Customs Service, vol. 2, unpublished, Library of the School of Oriental and African Studies, London 193. This group of documents will be subsequently referred to as The Maze Papers.

44 Maze appears to have solicited a report on this incident in March 1929. See Schjoth, 'Closing of the Customs House, Mr. Schjoth's Account of Incident', 27 Mar. 1929, The Maze Papers, vol. 19.

45 Teichman, telegram to Cecil Clementi, 3 Apr. 1927, The Clementi Papers.

46 Aitchison, 'The Chinese Maritime Customs Service', pp. 470-2. Aitchison provides a detailed overview of the factors that led to Maze being regarded as highly suitable by the Nationalists.

47 Atkins, Informal Empire in Crisis, pp. 80-1.

48 Lampson, 3 Jan. 1928, The Killearn Diaries.

49 Lampson, telegram to Chamberlain, 4 Jan. 1928, p. 3.

50 Miles Lampson, telegram to Austen Chamberlain, 11 Jan. 1928, document 18 of British Documents, vol. 34, p. 9. See also, the various entries in Lampson's Killearn Diaries, 18 Nov. 1927; 3, 4, 9, 19 and 30 Jan. 1928.

51 Lampson, 30 Jan. 1928, The Killearn Diaries.

52 Miles Lampson, telegram to Austen Chamberlain, 25 Jan. 1928, document 61 of British Documents, vol. 34, p. 49.

53 Miles Lampson, letter to Austen Chamberlain, 28 Jan. 1928, document 316 of British Documents, vol. 34, p. 260.

54 Miles Lampson, telegram to Austen Chamberlain, 9 July 1928, document 122 of British Documents, vol. 35, p. 106.

55 Austen Chamberlain, telegram to Miles Lampson, 20 July 1928, document 136 of British Documents, vol. 35, p. 118.

56 Lampson, 8 Dec. 1927, The Killearn Diaries. Edwardes and the Minister discuss the custody of the future of the Customs funds. Lampson comments, 'I must confess it is rather baffling having arm-chair experts sitting 6,000 miles away in Whitehall trying to dictate to us here the actual technical detail of how these things are to be carried out.'

57 Lampson, 4 Oct. 1928, The Killearn Diaries.

58 Miles Lampson, letter to Austen Chamberlain, 11 Apr. 1928, document 518 of British Documents, vol. 34, p. 440.

59 Lampson, letter to Chamberlain, 11 Apr. 1928, pp. 439-42.

60 Lampson, letter to Chamberlain, 11 Apr. 1928, p. 440.

61 Aitchison, 'The Chinese Maritime Customs Service', p. 502.

62 Newton, telegram to Earl of Birkenhead, 18 Sept. 1928, document 256 of British Documents, vol. 35, p. 247.

63 'The Customs', editorial, NCDN, 4 Oct. 1928.

64 Miles Lampson, telegram to Lord Cushendun, 25 Sept. 1928, document 262 of British Documents, vol. 35, p. 252.

65 'The Customs', NCDN, 4 Oct. 1928.

66 Miles Lampson, telegram to Lord Cushendun, 4 Oct. 1928, document 284 of British Documents, vol. 35, pp. 278-9.

67 Lampson, 4 Oct. 1928, The Killearn Diaries.

68 Miles Lampson, telegram to Lord Cushendun, 4 Oct. 1928, document 285 of British Documents, vol. 35, p. 280. 
69 Lord Cushendon, telegram to Miles Lampson, 5 Oct. 1928, document 286 of British Documents, vol. 35, p. 280. Lord Cushendon writes to Lampson, 'I am afraid that Mr Edwardes has made it more difficult for us to support him or to intervene on his behalf by pursuing, as he has done on previous occasions, an impolitic line of conduct.'

70 Lampson, 4 Oct. 1928, The Killearn Diaries.

71 'The I.-G. in Peking or Nanking, Mr Edwardes Said To Be Taking The Powers' Opinions on the Question', NCDN, 6 Oct. 1928.

72 A. Edwardes, 'Inspector General of Customs: Transfer of Office from Peking; Opening of Temporary Office in Shanghai', 24 Nov. 1928, Documents, vol. 4, p. 139.

73 Fung, The Diplomacy of Imperial Retreat, pp. 176-8.

74 'The Resignation of Mr. Edwardes', editorial, NCDN, 5 Jan. 1929.

75 Ibid.

76 Lampson, 28 Sept. 1928, The Killearn Diaries.

77 Chamberlain, telegram to Lampson, 20 July 1928, p. 118.

78 Lampson, 19 Jan. 1929, The Killearn Diaries.

79 Miles Lampson, telegram to Lord Cushendun, 4 Oct. 1928, document 284 of British Documents, vol. 35, p. 279

80 Lampson, 28 Sept. 1928; 4 Oct. 1928, and 5 Oct. 1928, The Killearn Diaries.

81 Austen Chamberlain, telegram to Miles Lampson, 14 Jan. 1929, document 36 of British Documents, vol. 36, p. 62.

82 Chamberlain, telegram to Lampson, 14 Jan. 1929, p. 63.

83 'The Chinese Customs. New Inspector General. Mr Maze Chosen', The Times, 10 Jan. 1929.

84 Miles Lampson, telegram to Austen Chamberlain, 14 Jan. 1929, document 35 of British Documents, vol. 36, p. 62. The oath taken by Maze was also featured in the NCDN, 11 Jan. 1929.

85 'The Customs', editorial, NCDN, 12 Jan. 1929.

86 Ibid.

87 Lampson, telegram to Chamberlain, 14 Jan. 1929, p. 62.

88 Lampson, 16 Nov. 1929, The Killearn Diaries.

89 Ibid.

90 Frederick Maze, letter to Stephenson, 27 Dec. 1929, The Maze Papers, vol. 3.

91 NCDN, 12 Jan. 1929.

92 Frederick Maze, circular no. 3856 (second series), 2 Feb. 1929, Documents, vol. 4, p. 162.

93 Ibid.

94 Ibid.

95 'Customs Autonomy Day', NCDN, 24 Jan. 1929.

96 NCDN, 31 Jan. 1929.

97 Frederick Maze, letter to Stephenson, 6 Apr. 1929, document 249 of British Documents, vol. 37, pp. 321-4.

98 A.H.F. Edwardes, semi-official circular no. 54, 24 Feb. 1927, Documents, vol. 4, pp. 126-7.

99 F.W. Maze, circular no. 3846 (second series), 21 Jan. 1929, Documents, vol. 4, p. 149.

100 F.W. Maze, circular no. 3857 (second series), 4 Feb. 1929 Documents, vol. 4, pp. $163-5$.

101 Aitchison, 'The Chinese Maritime Customs Service', pp. 499-500.

102 Miles Lampson, letter to A. Henderson, 10 Dec. 1929, document 494 of British, vol. 36, p. 421.

103 Lampson, letter to Henderson, 10 Dec. 1929, p. 421. 
5 Charting a new course: the proposed Hong Kong-China Trade and Customs Agreement, 1929-30

1 F.W. Maze, letter to Tyler, 4 Feb. 1931, The Papers of Sir Frederick Maze Relating to the Chinese Maritime Customs Service, vol. 5, Library of the School of Oriental and African Studies, London. These papers will subsequently be referred to as The Maze Papers.

2 Peter Wesley-Smith, Unequal Treaty 1898-1997: China, Great Britain and Hong Kong's New Territories, Hong Kong: Oxford University Press, 1980, p. 20.

3 S. Charles Hill, 'Pirates of the China Seas: Adventures of East and West in Quelling Sea-Roving Enemies of the Human Race', Asia Apr. 1924, pp. 306-28. This article gives a historical overview of the problem of piracy in the China Seas.

4 'The Piracy Problem', NCDN, 20 May 1914; 'Piracy on Canton River', NCDN, 11 Sept. 1923; 'Pirate Attack at Woosung', $N C D N, 3$ June 1932. The $C Y B$ also often included a section on shipping which also covered piracies. See George E. Sokolsky, 'Shipping', CYB 1926-7, ed. H.G.W. Woodhead, vol. 2, Nendeln Liechtenstein: Kraus Reprint, 1969, pp. 830-9; and 'Shipping', CYB 1929-30, ed. H.G.W. Woodhead, Tientsin: The Tientsin Press, 1929, pp. 795-806. Also a children's novel by Stormrail (pseud.), Pirates and Perils, London: The Sheldon Press, n.d., recounts the adventures of a British officer on the China seas. This novel reveals an intimate knowledge of China and tells the tale of the notorious pirate 'Mr Chang' who would board ships as a passenger and then proceed to take over the ship.

5 Following the attack on the Anjing (in September 1928) questions were asked in British parliament. General Officers Commanding in Shanghai and Hong Kong were authorized to provide military guards to travel on steamers on the Hong Kong, Singapore, Shantou and Xiamen routes. 'Shipping', CYB 1929-30, pp. 801-2.

6 'Piracy and Military Interference with Shipping', CYB 1926-7, vol. 2, pp. 830-9.

7 Ibid., p. 838.

8 'Shipping', CYB 1929-30, pp. 795-806. The piracies discussed included the ships: Irene, Sunning, Haiping (a river piracy in the Yangzi which also involved three other vessels), San Nam Hoi, Hirao Maru, Tean and Anjing. The article also includes a contribution to the China Mail, Hong Kong by Li Chung-yin entitled 'Inside Story of Pirate Activities' (Ibid., pp. 803-6).

9 C.A.S. Williams, Chinese Tribute, London: Literary Services and Production, 1969, pp. 46-9.

10 Ibid., p. 48.

11 Stanley F. Wright, Hong Kong and the Chinese Customs, Inspectorate Series number 7, Shanghai: Statistical Department of the Inspectorate General of Customs, 1930, p. 17.

12 'Memorandum on the Hongkong Customs Agreement', c.31 Mar. 1930, Colonial Office document series 129, Public Records Office, London, p. 88.

13 Wesley-Smith, Unequal Treaty 1898-1997, p. 20.

14 'Memorandum on the Hongkong Customs Agreement' pp. 88-9.

15 Robert Hart, letter to C. MacDonald, 27 June 1898 in 'Memorandum on the Hongkong Customs Agreement', pp. 151-4.

16 'Memorandum on the Hongkong Customs Agreement', pp. 89-91.

17 Ibid., pp. 93-4.

18 See Wesley-Smith; and Norman Miners, Hong Kong Under Imperial Rule 1912-1941, New York: Oxford University Press, 1987. Both touch on the CMCS and its relationship with Hong Kong. For a livelier account of the CMCS and 
its contact with Hong Kong see Frank Welsh, A History of Hong Kong, London: Harper Collins, 1993.

19 Wright, Hong Kong and the Chinese Customs.

20 Ibid., see Frederick Maze, 'Foreword', pp. iii-iv.

21 Miles Lampson, 'Annual Report, 1929', British Documents on Foreign Affairs: Reports and Papers from the Foreign Office Confidential Print, Part 2, Series E, vol. 20, Frederick: University Publications of America, 1984, p. 270. This series title will be subsequently abbreviated as British Documents and all references to this title refer to part 2, series E.

22 Wright, Hong Kong and the Chinese Customs, p. 17.

23 F.W. Maze, semi-official circular no. 61, 24 June 1929, Documents Illustrative of the Origin, Development and Activities of the Chinese Customs Service, vol. 4, Shanghai: Statistical Department of the Inspectorate General of Customs, 1939, pp. 245-9. This series will subsequently be referenced as Documents.

24 Ibid., p. 246. Other areas listed for special security included the Tonkin frontier, Guangzhouwan, the Korean frontier and the Russian frontier.

25 Ibid.

26 Ibid., p. 249.

27 'Memorandum on the Hongkong Customs Agreement', p. 92.

28 Wright, Hong Kong and the Chinese Customs, p. 17.

29 Ibid.

30 Ibid.

31 Ibid, p. 18.

32 Ibid., pp. 18-20. Wright provides copies of and a comparison of the 1918 and 1929 drafts.

33 Ibid, p. 21.

34 'Memorandum on the Hongkong Customs Agreement', p. 93.

35 F.W. Maze, letter to undisclosed recipient in London, 21 Oct. 1929, The Maze Papers, vol. 18.

36 Stephenson, letter to F.W. Maze, 25 Nov. 1930, The Maze Papers, vol. 5.

37 'Memorandum on the Hongkong Customs Agreement.'

38 F.W. Maze, circular no. 3990 (second series), 24 Oct. 1929, Documents, vol. 4, p. 244.

39 Ibid.

40 F. Hayley Bell, 'South-East China Coast Investigation Commission', 5 May 1930, Documents, vol. 4, p. 279.

41 Ibid.

42 Ibid., pp. 80-1.

43 Ibid., p. 281.

44 Ibid., p. 283.

45 Ibid., p. 282.

46 Ibid., p. 285.

47 Miles Lampson, telegram to A. Henderson, 2 Jan. 1930, British Foreign Office document series 405, Public Record Office, London.

48 Ibid.

49 'Memorandum on the Hongkong Customs Agreement', pp. 131-2.

50 Ibid., p. 129.

51 F.W. Maze, 'Proposed Customs Agreement with Hong Kong in Re:' 23 May 1930, The Maze Papers, vol. 18.

52 There was discussion of disapproval of Clementi in Colonial Office papers as it was believed he had been too independent in the negotiations and had not given due reference to the authorities.

53 'Hong Kong Welcome to New Governor', NCDN, 10 May 1930. 
54 William Peel, paraphrase telegram to Secretary of State for the Colonies, 17 May 1930, Colonial Office document series, p. 129.

55 Wesley-Smith, Unequal Treaty 1898-1997, pp. 138-9.

56 F.W. Maze, letter to E. Ensor, 23 May 1935, The Maze Papers, vol. 10.

57 Possibly from the Butterfield and Swire business empire.

58 E. Teichman, C.M.G., C.I.E. was the Chinese Secretary in the British legation. 'Foreign Diplomatic and Consular Services', CYB 1929-30, p. 1107.

59 Miles Lampson, 14 June 1930, The Killearn Diaries: Being the Diaries of Sir Miles Wedderburn Lampson, vol. 1, ms., St Antony's College Middle East Centre, University of Oxford.

60 'The Principle at Hong Kong', editorial, NCDN, 23 May 1930.

61 The China Association was a British lobby group that consisted of ex-China businessmen among others.

62 'The Principle at Hong Kong.'

63 F.W. Maze, letter to Stephenson, 29 Sept. 1930, The Maze Papers, vol. 5.

64 Ibid.

65 'Mr Maze Going to Hong Kong', NCDN, 20 Oct. 1930.

66 F.W. Maze, telegram to Stephenson, 20 Oct. 1930, The Maze Papers, vol. 5.

67 Frederick Maze, letter to Newton Stabb, 13 Nov. 1930, The Maze Papers, vol. 5.

68 Maze, telegram to Stephenson, 20 Oct. 1930.

69 Miles Lampson, letter to A. Henderson, 31 Oct. 1930, British Foreign Office document series 405, pp. 33-7.

70 Lampson, 14 June 1930, The Killearn Diaries.

71 Lampson, letter to A. Henderson, 31 Oct. 1930, pp. 33-4.

72 A copy of the earlier proposed agreements can be found in Wright, Hong Kong and the Chinese Customs, the November draft can be found in the Maze Papers, vol. 18.

73 'The Hongkong-China Trade and Customs Agreement (Draft)', 6 Nov. 1930, The Maze Papers, vol. 18, p. 442.

74 F.W. Maze, letter to J.J. Paterson, 24 Dec. 1930, The Maze Papers, vol. 5. Paterson was the head of Jardine Matheson's, Hong Kong.

75 S.F. Wright, China's Struggle for Tariff Autonomy: 1843-1938, Shanghai: Kelly and Walsh, 1938, pp. 646-7.

76 T.V. Soong, letter to F.W. Maze, 27 Oct. 1930, The Maze Papers, vol. 5.

77 Miles Lampson, 'Annual Report, 1930', British Documents, vol. 20, p. 370.

78 F.W. Maze, letter to Lyall, 21 Nov. 1930, The Maze Papers, vol. 5.

79 F.W. Maze, letter to Stephenson, 21 Nov. 1930, The Maze Papers, vol. 5.

80 See Maze, letter to Stephenson, 29 Sept. 1930; Maze, letter to Lyall, 21 Nov. 1930.

81 Maze, letter to Lyall, 21 Nov. 1930.

82 Maze, letter to Stephenson, 21 Nov. 1930.

83 Lampson, 'Annual Report, 1930', p. 370.

84 Frederick Maze, letter to Stabb, 13 Nov. 1930.

\section{A Service in decline}

1 F.W. Maze, letter to H. Harris, 20 Aug. 1930, The Papers of Sir Frederick Maze Relating to the Chinese Maritime Customs Service, vol. 5, Library of the School of Oriental and African Studies, London. This series of documents will subsequently be referred to as The Maze Papers.

2 It was not uncommon for warlords to seek the service of a Western journalist to act as adviser and, one suspects, to act simultaneously as a publicity man for the Western powers. Zhang Xueliang often requested the counsel of William H. Donald, an Australian journalist. See Earle Albert Selle, Donald Of China, Sydney: Invincible Press, 1948. This use of foreign 'front men' is discussed in 
Hallett Abend, My Years In China, London: Lane, 1944, pp. 57-8. Abend, an American journalist in China, was approached by Zhang Zuolin: 'old Marshal Chang Tso-lin wanted to hire me as a combination of publicity manager and foreign contact adviser. This sounded romantic and interesting.' However, Abend was dissuaded from getting involved in Chinese politics by American Minister to China, MacMurray.

3 Feng Yuxiang had collaborated with the GMD forces as early as 1926. Feng's forces were exhausted by continual clashes with other warlords and therefore in reality could have offered little effective resistance to the Northern Expedition. Hsi-sheng Ch'i, Warlord Politics in China 1916-1928, Stanford: Stanford University Press, 1976, pp. 177-8.

4 Feng Yuxiang was commonly known as the 'Christian General' and sought to spread his hard work and physical fitness ethos to his troops. In contrast Yan Xishan's education was much more impressive than that of Feng and his exposure to Western concepts and to Sun Yatsen's early movement influenced his attempts at ideological indoctrination of his stronghold, the province of Shanxi (Shansi). In fact, 'Yen once boasted that he had formulated an ideology embodying the best features of militarism, nationalism, anarchism, democracy, capitalism, communism, individualism, imperialism, universalism, paternalism and utopianism.' Donald G. Gillin, Warlord: Yen Hsi-shan in Shansi Province, 1911-1949, Princeton: Princeton University Press, 1967, p. 63.

5 James E. Sheridan, Chinese Warlord: The Career of Feng Yu-hsiang, Stanford: Stanford University Press, 1966, p. 263. This public denunciation of one's opponent (albeit through a subordinate's requests) followed an accepted protocol of diplomatic behaviour for the warlords. This protocol is outlined in detail in Ch'i, Warlord Politics in China, pp. 179-195.

6 Ibid., p. 264.

7 Ibid., pp. 261-2.

8 C.E. Gauss, 'Monthly Political Review for May 1930', Tientsin, American Consulate General, June 1930, p. 3.

9 Miles Lampson, telegram to A. Henderson, 27 May 1930, British Foreign Office document series 405, Public Record Office, London.

10 The NCDN, 17 June-Oct. 1930. It is significant, however, that Customs reports of the takeover infer that Yan and Feng were 'caught off guard' by Simpson's seizure of the Customs on their behalf. See the documents authored variously by F.W. Maze, F. Hayley Bell and B. Lenox Simpson in Documents Illustrative of the Origin, Development and Activities of the Chinese Customs Service, vol. 4, Shanghai: Statistical Department of the Inspectorate General of Customs, 1939, pp. 387-426. In this chapter, this series will be referred to as Documents.

11 F.W. Maze, letter to Stephenson, 24 Apr. 1930, The Maze Papers, vol. 4.

12 F. Hayley Bell, enclosure no. 2 to semi-official circular no. 72, 28 Sept. 1930, Documents, vol. 4, p. 406.

13 Gauss, 'Monthly Political Review for May 1930', p. 3.

14 Chinese Maritime Customs Service, Annual Report for 1930, Shanghai: Statistical Department of the Inspectorate General of Customs, 1931, chart no 3. The Haikwan Tael or Haiguan Liang was a unit of account and not in circulation. Duties were paid by converting Hk.Tl into local currency.

15 Ibid.

16 F.W. Maze, letter to Stephenson, 12 May 1930, The Maze Papers, vol. 4.

17 Ibid.

18 Miles Lampson, 12 May 1930, The Killearn Diaries: Being the Diaries of Sir Miles Lampson, vol. 1, ms., St Antony's College Middle East Centre, University of Oxford. 
19 Lampson, 13 May 1930, The Killearn Diaries.

20 Miles Lampson, telegram to A Henderson, 16 June 1930, document 158 of British Documents on Foreign Affairs: Reports and Papers from the Foreign Office Confidential Print, part 2, series E, vol. 38, Frederick: University Publications of America, 1984, p. 161. This series title will be subsequently abbreviated as British Documents and all references to this title refer to part 2, series E.

21 L.C. Arlington, Through The Dragon's Eyes: Fifty Years' Experiences of a Foreigner in the Chinese Government Service, London: Constable and Co., 1931, deals with the author's involvement in the Tianjin Customs. Arlington posits an interesting contention as regards the motives of the Yan-Feng faction for taking the Customs house, contending that the motives were not merely for financial gain, but rather that the Customs in Tianjin were an espionage centre for the Nanjing Government. Although an intriguing proposition, this claim cannot be supported in light of the material so far consulted. See Arlington, pp. 252-8.

22 Ibid., p. 254.

23 Ibid., p. 256.

24 F.W. Maze, telegram to F. Hayley Bell, 28 June 1930, The Maze Papers, vol. 4.

$25 N C D N, 18$ June 1930 and 23 June 1930.

26 Miles Lampson, telegram A. Henderson, 19 June 1930, document 166 in British Documents, vol. 38, p. 165.

27 F.W. Maze, letter to Stephenson, 1 July 1930, The Maze Papers, vol. 4.

28 See the monthly political reviews for May and June 1930 by US Consul General in Tianjin, C.E. Gauss. Also Gauss, 'Monthly Political Review for June 1930', p. 5.

29 Ibid.

30 F.W. Maze, letter to Stephenson, 25 June 1930, The Maze Papers, vol. 4.

31 Lampson, 7 May 1930, The Killearn Diaries.

32 Ibid.

33 Miles Lampson, telegram to Henderson, 19 June 1930.

34 A London newspaper mentions, "Chinese bankers in conversation dwell on the obvious difficulty which $\mathrm{Mr}$ Maze will have in resisting the demands of the political faction which put him into office.' 'The Chinese Customs', The Times, 11 Jan. 1929.

35 Foreign lives were not endangered, taking the impetus away from any contemplated naval action.

36 See section on the Chinese Maritime Customs Service in Miles Lampson, 'Annual Report, 1930', British Documents, vol. 20, pp. 367-9.

37 See Lampson's entries between 23 June and 1 July 1930 in The Killearn Diaries.

38 In the treaty port system, allotments of land had been allocated to the treaty powers for the residence and trade of their nationals. Each concession then fell under that nation's jurisdiction and was policed and administered by its own nationals. The French Concession in Tianjin was an example of such an enclave of French control in a treaty port.

39 Miles Lampson, 'Annual Report, 1930', p. 368.

40 Maze, letter to Stephenson, 25 June 1930.

41 Maze, letter to Stephenson, 25 June 1930.

42 'The Tientsin Customs: Yen's Dilemma', The Times, 9 May 1930.

43 Nicholas Clifford, 'Sir Frederick Maze and The Chinese Maritime Customs, 1937-1941', Journal of Modern History, 37.1 (March 1965): 20.

44 Lampson, 24 June 1930, The Killearn Diaries.

45 Lampson, 16 June 1930, The Killearn Diaries.

46 Lampson, 16 and 19 June 1930, The Killearn Diaries.

47 Lampson, 16 June 1930, The Killearn Diaries.

48 'Mr Lenox Simpson Interviewed', NCDN, 20 June 1930. 
49 F.W. Maze, letter to Stephenson, 18 June 1930, The Maze Papers, vol. 4; F.W. Maze, letter to Lyall, 26 Aug. 1930, The Maze Papers, vol. 5.

50 F.W. Maze, letter to Stephenson, 23 July 1930, The Maze Papers, vol. 4.

51 Ibid.

52 Maze, letter to Lyall, 26 Aug. 1930.

53 F.W. Maze, letter to Stephenson, 15 Aug. 1930, The Maze Papers, vol. 5; Maze, letter to Lyall, 26 Aug. 1930; Maze, letter to Stephenson, 18 June 1930.

54 Maze, letter to Lyall, 26 Aug. 1930

55 A. Henderson, telegram to Miles Lampson, 25 July 1930, document 226 in British Documents, vol. 38, pp. 210-11.

56 A. Henderson, telegram to Miles Lampson, 28 July 1930, document 228 in British Documents, vol. 38, pp. 211-12.

57 Sheridan, Chinese Warlord, pp. 266-7.

58 Lampson, 'Annual Report, 1930', p. 369.

59 'Gunmen Attack Lenox Simpson. Tientsin Commissioner of Customs under Yen Hsi-shan's Regime Shot in Back by Mysterious Visitors to Private Residence', NCDN, 3 Oct. 1930.

60 F.W. Maze, letter to Stephenson, 6 Oct. 1930, The Maze Papers, vol. 5.

61 Ibid.

62 'The Outrage', editorial, $N C D N, 4$ Oct. 1930.

63 Maze, letter to Stephenson, 18 June 1930.

64 Maze, letter to Lyall, 26 Aug. 1930.

65 Maze, letter to Stephenson, 6 Oct. 1930; Tsai Tang Kan, letter to F.W. Maze, 7 Oct. 1930, The Maze Papers, vol. 5; F.W. Maze, telegram to Stephenson, 20 Oct. 1930, The Maze Papers, vol. 5; and F.W. Maze, letter to Newton Stabb, 13 Nov. 1930, The Maze Papers, vol. 5.

66 'Government Faced with Political Crisis', NCDN, 1 May 1931.

67 'Canton Preparing for War', NCDN, 13 May 1931.

68 F.W. Maze, letter to T.V. Soong, 27 May 1931, The Maze Papers, vol. 5.

69 F.W. Maze, letter to Miles Lampson, 28 May 1931, The Maze Papers, vol. 5.

70 Braud, telegram to F.W. Maze, 3 June 1931, The Maze Papers, vol. 5.

71 Miles Lampson, 'Annual Report, 1931', British Documents, vol. 20, p. 436.

72 F.W. Maze, letter to Song, 3 June 1931, The Maze Papers, vol. 5.

73 'Customs Coup in Canton', NCDN, 6 June 1931.

74 F.W. Maze, telegram to Braud, 5 June 1931, The Maze Papers, vol. 5.

75 Maze, telegram to Braud, 5 June 1931.

76 'Canton and the Govt', NCDN, 17 June 1931.

77 'The Customs', editorial, NCDN, 16 June 1931.

78 Lampson, 'Annual Report, 1931', p. 436.

79 'Canton Short of Funds', NCDN, 21 June 1931.

80 Lampson, 'Annual Report, 1931', pp. 392-3.

81 W.O. Law, letter to F.W. Maze, 11 Feb. 1932, The Maze Papers, vol. 7.

82 For an overview of existing research on the origins and formation of Manzhuguo the following works are of immediate interest. Gavan McCormack, 'Manchukuo: Constructing the Past', East Asian History, 2 (December 1991): 105-24; Peter Duus, Ramon H. Myers and Mark R. Peattie, eds, The Japanese Informal Empire in China, 1895-1937, Princeton: Princeton University Press, 1989; Ian Nish, Japan's Struggle With Internationalism: Japan, China and the League of Nations, 1931-3, London: Kegan Paul International, 1993; and Louise Young, Japan's Total Empire: Manchuria and the Culture of Imperialism, London: University of California Press, 1998.

83 Captain Nakamura was a Japanese intelligence officer found dead in the midst of travels around Manchuria. Nakamura's death was under suspicious circumstances as he was not travelling as a Japanese officer at the time but rather was 
disguised as a Chinese civilian. It is most likely that Nakamura was arrested while acting as a Japanese spy in the region.

84 Hallett Abend, My Years in China 1926-1941, London: Lane, 1944. For Abend's full account of his observations on the Japanese in Manchuria in the early 1930s in particular, see Abend, pp. 147-73.

85 Ibid., p. 166. Abend was also the author of Chaos in Asia and Japan Unmasked among other works.

86 See North-China Herald (hereafter NCH) and NCDN in February 1932.

87 'The Dairen Outrage', editorial, NCDN, 25 June 1932.

88 'Maritime Customs Revenue Collection at Manchurian Ports', enclosure no. 1 to semi-official circular no. 95, Documents, vol. 5, p. 161.

89 F.W. Maze, letter to T.V. Soong, 21 Mar. 1932, The Maze Papers, vol. 7.

90 See The Maze Papers, vol. 7 for a detailed report by both Fukumoto and Ding as to their discussions. Especially F.W. Maze, letter to Song, 24 Mar. 1932; Ding, appendix letter to F.W. Maze, 19 Mar. 1932 in the same volume.

91 Jinzaburo Fukumoto, letter to F.W. Maze, 19 Mar. 1932, The Maze Papers, vol. 7.

92 Ibid.

93 Ibid.

94 F.W. Maze, letter to T.V. Soong, 24 Mar. 1932, The Maze Papers, vol. 7.

95 Maze, letter to Soong, 24 Mar. 1932.

96 F. Lindley, letter to John Simon, 1 Apr. 1932, document 218 of British Documents, vol. 40, p. 300.

97 F.W. Maze, letter to Walsham, 2 Apr. 1932, The Maze Papers, vol. 7. Maze discusses at length his approaches and suggestions to the Nanjing Government and reveals his fear that he may indeed be left responsible should any crisis erupt.

98 Ibid.

99 Ibid.

100 Ibid.

101 Miles Lampson, letter to F.W. Maze, 22 Mar. 1932, The Maze Papers, vol. 7; Maze, letter to Walsham, 2 Apr. 1932. Maze writes of Lampson: '[he] has done everything possible at his end to endeavour to secure the integrity of the Manchurian Customs, and no man can do more than his best!'

102 Miles Lampson, letter to John Simon, 5 Apr. 1932, document 225 of British Documents, vol. 40, p. 311.

103 Ibid., pp. 310-15.

104 Walsham, letter to Maze, 16 Mar. 1932, The Maze Papers, vol. 7.

105 F.W. Maze, letter to W.O. Law, 4 Apr. 1932, The Maze Papers, vol. 7.

106 F.W. Maze, letter to Walsham, 1 July 1932, The Maze Papers, vol. 7.

107 Ibid.

108 Maze, letter to Walsham, 2 Apr. 1932.

109 F.W. Maze, letter to Miles Lampson, 13 Apr. 1932, The Maze Papers, vol. 7.

110 'Concern Over Manchuria: Report About Changes in Customs Administration', $N C D N, 10$ June 1932. Also the various articles that appeared in the NCDN: 'Japan Adrift', editorial, 11 June 1932; 'Recognition of Manchukuo', 11 June 1932; 'Manchukuo Currency', 15 June 1932; 'The Manchurian Customs', 16 June; 'Japan's Robot', editorial, 21 June 1932; 'The Manchurian Customs Dispute', 21 June 1932; 'Customs Crisis in Manchuria', 22 June 1932; 'Customs Seized in Manchuria', 23 June 1932; 'Dairen Customs Seizure', 24 June 1932; 'The Dairen Outrage', editorial, 25 June 1932; 'Dairen Commissioner of Customs Dismissed', 25 June 1932; 'Manchukuo Authorities' Customs Revolt', 26 June 1932; 'The Manchukuo Customs Revolt Developing', 27 June 1932, 
'Under Arms', editorial, 28 June 1932; 'Customs Officials Loyal Against Inducements', 28 June 1932; 'The Customs Seizure', 29 June 1932.

111 'Japan Adrift', editorial, NCDN, 11 June 1932.

112 'Appendix of Telegrams Relating to Maze Fukumoto Exchange in the Lead Up to Fukumoto's Dismissal', in F.W. Maze, letter to Walsham, 1 July 1932, The Maze Papers, vol. 7.

113 F.W. Maze, semi-official circular no. 95, 20 Apr. 1933, Documents, vol. 5, p. 152.

114 'Appendix of Telegrams Relating to Maze Fukumoto Exchange.'

115 Ibid.

116 Maze, letter to Walsham, 1 July 1932.

117 'Appendix of Telegrams Relating to Maze Fukumoto Exchange.'

118 'The Dairen Outrage', NCDN, 25 June 1932. See also the article 'Dairen Commissioner of Customs Dismissed' in the same issue.

119 'The Dairen Outrage.'

120 Maze, semi-official circular no. 95, p. 152.

121 Ingram, letter to John Simon, 1 Aug. 1932, document 117 in British Documents, vol. 41, p. 160.

122 Ibid.

123 'Under Arms', editorial, NCDN, 28 June 1932.

124 Maze, semi-official circular no. 95.

125 H.E. Prettejohn, letter to F.W. Maze, 30 Aug. 1932 Documents, vol. 5, pp. 170-9.

126 Prettejohn, letter to Maze, 30 Aug. 1932, p. 178.

127 F.W. Maze, 'Copy of Despatch to Japanese Chargé d'Affaires from Inspector General', 12 July 1932, The Maze Collection, National Maritime Museum, Greenwich.

128 Prettejohn, letter to Maze, 30 Aug. 1932, pp. 177-8.

129 N.R. Shaw, letter to F.W. Maze, 20 Aug. 1932, Documents, vol. 5, p. 213.

130 C.H.B. Joly, letter to F.W. Maze, 14 Nov. 1932, Documents, vol. 5, pp. 163-9.

131 Shaw, letter to Maze, 20 Aug. 1932, pp. 215-16.

132 F.W. Maze, letter to Walsham, 28 June 1932, The Maze Papers, vol. 7.

133 F.W. Maze, circular no. 4574 (second series), 2 Mar. 1933, Documents, vol. 5, pp. 122-3.

134 Maze, circular no. 4574 (second series).

135 See Ann Trotter, 'Backstage Diplomacy: Britain and Japan in the 1930s', Journal of Oriental Studies, 15.1 (Jan. 1977), pp. 39-40 for a brief discussion of Edwardes and Manzhuguo.

136 Manzhuguo Government, Bureau of Information and Publicity, Department of Foreign Affairs, Manchukuo Handbook of Information (Hsinking: Manzhuguo Government, 1933), p. 25.

137 F.W. Maze, letter to J.W. Stephenson, 17 July 1933. The Maze Papers, vol. 9.

138 Ingram, telegram to R. Vansittart, 8 July 1932, document 291 of British Documents, vol. 40, pp. 404-5.

7 'Steadfast and fearlessly persistent': the CMCS in the face of war, 1937-45

1 Ann Trotter, Britain and East Asia 1933-1937, London: Cambridge University Press, 1975, p. 19.

2 NMM the Maze Papers, [MS79/165/2] F. Maze to Sir John Simon, 4 June 1935.

3 Ibid.

4 NMM The Maze Papers, [MS79/165/2] F. Maze to J.H. Macoun, 14 November 1935. 
5 NMM the Maze Papers, [MS79/165/2] F. Maze to Sir John Simon, 4 June 1935.

6 'A Great Asset', NCH, 24 February 1937.

7 Evan Luard, Britain and China, London: Chatto \& Windus, 1962, pp. 43-5.

8 Ibid., p. 42.

9 Ibid., p. 44.

10 Christopher Briggs, Hai Kuan: The Sea Gate, Cheshire: Lane, 1997, pp. 108-10.

11 Ibid., p. 110.

12 'Smuggling in North Continues: Heavy loss to Customs Show by Latest Figures', NCH, 3 February 1937.

13 Ibid.

14 NCH, 17 February 1937.

15 'Amoy Smuggling Situation', NCH, 31 March 1937, and 'Smuggling Activities in Foochow', NCH, 14 April 1937.

$16 \mathrm{NCH}, 31$ March 1937.

17 'Customs Officer Shot Dead', NCH, 13 Jan 1937.

18 Ibid.

19 'Smuggling Affair near Tsingtao', NCH, 24 February 1937. This article provides an example of the risks involved in boarding vessels. A crew member threatened CMCS officers with an axe, forcing them to draw their pistols.

20 'Customs Ships Victimized by Japanese', NCH, 15 Sept. 1937.

21 Bradford A. Lee, Britain and the Sino-Japanese War, 1937-1939: A Study in the Dilemmas of British Decline, Stanford: Stanford University Press, 1973, p. 115.

22 NMM The Maze Papers, [MS79/165/2] F. Maze to Cubbon, 2 October 1939.

23 NCH, 15 Dec 1937.

24 Lee, Britain and the Sino-Japanese War, pp. 117-18.

25 J.R.S., 'Significant Developments: Japanese Tactics on Shanghai and Manchukuo Customs', Far Eastern Survey, vol. 6, Issue 25 (22 December 1937): 290.

26 Kurt Bloch, 'Britain Recognizes Japanese Control of Chinese Customs', Far Eastern Survey, vol. 7, Issue 11 (1 June 1938): 131.

27 Lee, Britain and the Sino-Japanese War, p. 119.

28 Bloch, 'Britain Recognizes Japanese Control', p. 131.

29 Ibid.

30 Zhong-ping Feng, The British Government's China Policy 1945-1950, Staffordshire: Ryburn Publishing, 1994, p. 13.

31 NMM The Maze Papers, [MS 79/165/3] Maze to Cubbon (NRS) 17 December 1942.

32 NMM The Maze Papers, [MS79/165/2] F. Maze to F. Chang, February 1944.

33 NMM The Maze Papers, [MS79/165/3] Maze to Cubbon 24 December 1942. Maze recounted that he was criticized by Britain's China watchers for expressing these views but he remained unapologetic as he believed that, with China's coming of age, there was less need for an institution like the Customs. Maze believed that IG Hart's prophecy regarding the limited future of the MCS was finally coming to fruition.

34 NMM The Maze Papers, [MS79/165/3] Maze to Ting 1 May 1945.

35 NMM The Maze Papers, [MS79/165/3] Maze to Cubbon 20 Feb 1943.

36 NMM The Maze Papers, [MS79/165/3] 'A Brief Outline of Political Developments in the Far East, 1911-1943'. c.1947.

37 In part this was fuelled by Maze's belief that by not clearing his own name at Kong's expense and therefore allowing Kong to 'save face' with the Generalissimo he had prevented having two enemies rather than one. NMM The Maze papers, [MS79/165/3] 'A Brief Outline of Political Developments in the Far East, 1911-1943.' c.1947.

38 The Times, Tuesday 1 June 1943. 
39 The Times, Tuesday 1 June 1943.

40 NMM The Maze Papers, [MS79/165/2] F. Maze to Zhang, February 1944.

41 NMM The Maze Papers, [MS79/165/2] F. Maze to Sir Charles Addis, 5 April 1944.

42 NMM The Maze Papers, [MS79/165/2] F. Maze to F. Chang, February 1944.

43 NMM The Maze Papers, [MS79/165/9] Translation of dispatch No. 8375 of 4 October 1945 from His Excellency the Minister of Finance to the Inspector General of Customs. Contained as an enclosure in a letter, Little to Maze, 7 October 1945.

44 Zhong-ping Feng, The British Government's China Policy, p. 14.

45 Ibid., p. 22.

46 J.P. Jain, China in World Politics: A Study of Sino-British Relations 1949-1975, New Delhi: Radiant Publishers, 1976, pp. 12-13.

47 Some of the reasons provided by Maze include the refusal of the British Government to discuss the retrocession of Kowloon outright; that, during the retreat from Burma, a British contingent withdrew and left a Chinese detachment; and the sending of the 'Desert Victory' film as an afterthought. NMM The Maze papers, [MS79/165/3] 'Brief Outline of Political Developments in the Far East 1911-1943'.

48 NMM The Maze Papers, [MS79/165/3] contains some evidence of this tension. Within this is a working file with a note on the cover indicating that it was set aside for Little but Maze annotated the front of the file: 'I ultimately decided not to leave behind confidential and private correspondence.'

49 NMM The Maze Papers, [MS 79/165/3] Maze to Cubbon 3 March 1943.

50 Ibid.

51 Jain, China in World Politics, p. 14.

52 Luard, Britain and China, p. 56.

53 The issue of personal property is discussed in a number of exchanges. NMM, The Maze Papers, [MS79/165/9] Ting to Little 6 October 1945; Ting to Maze 26 October 1945; Ting to Little 26 October 1945; Ting to Maze 15 February 1946; Ting to Maze 14 May 1946; Foster Hall to Maze 31 January 1946; Maze to Foster Hall 19 February 1946.

54 In this instance, personal items were believed to be intact but once shipped to Maze he discovered that jewellery had been stripped of its precious gems.

55 NMM The Maze Papers, [MS79/165/3] Ting to Maze 26 March 1945.

56 Briggs, p. 119. Briggs recounts that he had been working with the Admiralty in London. He was contacted by the NRS in 1946 to return to China but, once he learnt that his wife could not join him, he declined this offer. 


\section{Bibliography}

Abend, Hallett, My Years in China 1926-1941, London: Lane, 1944.

Acheson, Guy F.H. and Cecil A.V. Bowra, Correspondence with Sir F.A. Aglen, Letter series Z, The Library of the School of Oriental and African Studies, London. Aglen, Francis A., Confidential correspondence with G.F.H. Acheson and C.A.V. Bowra, Letter series Z, The Library of the School of Oriental and African Studies, London.

Aitchison, Jean, 'The Chinese Maritime Customs Service in the Transition from the Ch'ing to the Nationalist Era: An Examination of the Relationship between a Western Style Fiscal Institution and the Chinese Government in the Period Before the Manchurian Incident', Diss. London University, 1983.

All About Shanghai and Environs: A Standard Guide Book, Shanghai: The University Press, 1934. Reprinted as All About Shanghai: A Standard Guidebook, Hong Kong: Oxford University Press, 1983.

Anderson, Perry, 'A Belated Encounter: Perry Anderson retraces his father's career in the Chinese Customs Service', London Review of Books, 30 July 1998: 5-10; 20 Aug 1998: 28-34.

Arlington, L.C., Through the Dragon's Eyes: Fifty Year' Experiences of a Foreigner in the Chinese Government Service, London: Constable and Co., 1931.

Atkins, Martyn, Informal Empire in Crisis: British Diplomacy and the Chinese Customs Succession, 1927-1929, Ithaca: East Asia Program, Cornell University, 1995.

Bickers, Robert, Britain in China: Community, Culture and Colonialism 1900-1949, Manchester: Manchester University Press, 1999.

Bloch, Kurt, 'Britain Recognizes Japanese Control of Chinese Customs', Far Eastern Survey, 7, 11 (1 June 1938): 131.

Boorman, Howard L. and Richard C. Howard, eds, Biographical Dictionary of Republican China, 6 vols, New York: Columbia University Press, 1967-79.

Bowra, Cecil, A.V. Memoirs of C.A.V. Bowra 1920-1932, ms. Manuscripts Collection. Library of the School of Oriental and African Studies, London.

Briggs, Christopher, Hai Kuan: The Sea Gate, Cheshire: Lane, 1997.

British Foreign Office Documents (series 405), Public Records Office, London.

Bythell, D., 'Class Community and Cultues: The Case of the Brass Band in Newcastle', Labour History: A Journal of Labour and Social History, 76 (Nov. 1994), pp. 144-5.

Cable, James, Gunboat Diplomacy: Political Applications of Limited Naval Force, London: Chatto and Windus, 1971. 
Cain, P.J. and A.G. Hopkins, British Imperialism: Crisis and Deconstruction 19141990, London and New York: Longman, 1993.

— British Imperialism: Innovation and Expansion 1688-1914, London: Longman, 1993.

Campbell, Robert Ronald, James Duncan Campbell: A Memoir by His Son, Cambridge: Harvard East Asian Monographs, 1970.

Chan, F. Gilbert, 'An Alternative to Kuomintang-Communist Collaboration: Sun Yat-sen and Hong Kong, January-June 1923', Modern Asian Studies, 13, 1 (1979): 127-39.

Chan, Lau Kit-ching, 'The Lincheng Incident - a Case Study of British policy in China Between the Washington Conference (1921-22) and the First Nationalist Revolution (1925-28)', Journal of Oriental Studies, 10, 2 (July 1972): 172-86.

_ ' 'The Succession of Sir Robert Hart at the Imperial Maritime Customs Service', Journal of Asian History, 9.1 (1975): 1-34.

— China, Britain and Hong Kong 1895-1945, Hong Kong: Chinese University Press, 1990.

Chang, Sidney H. and Leonard H.D. Gordon, All Under Heaven ... Sun Yat-sen and His Revolutionary Thought, Stanford: Hoover Institution Press, 1991.

Ch'i, Hsi-sheng, Warlord Politics in China 1916-1928, Stanford: Stanford University Press, 1976.

Chinese Maritime Customs Service, Service List 1895, 1896.

— Service List 1907, Shanghai: Statistic Department of the Inspectorate General of Customs, 1908.

- The Origin and Organisation of the Chinese Customs Service, Shanghai: Statistical Department of the Inspectorate General of Customs, 1922.

— Decennial Reports 1912-1921, Shanghai: Statistical Department of the Inspectorate General of Customs, 1924.

—- Customs Annual Report 1923-1930, Shanghai: Statistical Department of the Inspectorate General of Customs, 1924-1931.

—, Decennial Reports 1922-31, Shanghai: Statistical Department of the Inspectorate General of Customs, 1933.

—, Chinese Maritime Customs: Staff Organisation and Control, Shanghai: Statistical Department of the Inspectorate General of Customs, 1936.

- Documents Illustrative of the Origin, Development, and Activities of the Chinese Customs Service, 7 vols, Shanghai: Shanghai Statistical Department of the Inspectorate General of Customs, 1940.

Clementi, Cecil, Various documents, The Clementi Papers, Rhodes House Library, Oxford University, Oxford.

Clifford, Nicholas R., 'Sir Frederick Maze and the Chinese Customs, 1937-1941', Journal of Modern History, 37, 1 (Mar. 1965): 18-34.

- Retreat from China: British Policy in the Far East 1937-1941, London: Longmans, 1967.

Clyde, Paul Hibbert, ed. United States Policy Towards China: Diplomatic and Public Documents, 1839-1939, New York: Russell and Russell, 1964.

Colonial Office papers (series 129), Public Records Office, London.

Dayer, Roberta A., Bankers and Diplomats in Republican China, London: Frank Cass and Company, 1981.

Dean, Britten, 'British Informal Empire: the Case of China', The Journal of Comparative and Commonwealth Politics, 14 (1976): 64-82. 


\section{Bibliography}

Drage, Charles, Servant of the Dragon Throne: Being the Lives of Edward and Cecil Bowra, London: Peter Dawnay, 1966.

Duus, Peter, Ramon H. Myers and Mark R. Peattie, eds, The Japanese Informal Empire in China, 1895-1937, Princeton: Princeton University Press, 1989.

Dyer, Richard, A Matter of Images: Essays on Representations, London: Routledge, 1993.

Eastman, Lloyd, J. Ch'en, S. Pepper and L. Van Slyke, Nationalist Era in China, 1927-1949, New York: Cambridge University Press, 1991.

Endicott, Stephen Lyon, Diplomacy and Enterprise: British China Policy 1933-1937, Vancouver: University of British Columbia Press, 1975.

Fairbank, John King, Trade and Diplomacy on the China Coast: The Opening of the Treaty Ports 1842-1854, Cambridge: Harvard University Press, 1953.

— , 'Synarchy Under The Treaties', Chinese Thoughts and Institutions, ed. John King Fairbank, Chicago: University of Chicago Press, 1957.

— , 'The Early Treaty System in the Chinese World Order', The Chinese World Order: Traditional China's Foreign Relations, ed. John King Fairbank, Cambridge: Harvard University Press, 1968.

Feng, Zhong-ping, The British Government's China Policy 1945-1950, Keele: Ryburn Publishing, 1994.

Feuerwerker, Albert, 'The Foreign Presence in China', Republican China 1912-1949, vol. 12, part 1 of The Cambridge History of China, ed. John King Fairbank, New York: Cambridge University Press, 1983, pp. 128-207.

Fitzgerald, John, Awakening China: Politics, Culture, and Class in the Nationalist Revolution, Stanford: Stanford University Press, 1996.

Fung, Edmund S.K., 'The Chinese Nationalists and the Unequal Treaties 1924-1931', Modern Asian Studies, 21, 4 (1987): 793-819.

— The Diplomacy of Imperial Retreat: Britain's South China Policy, 1924-1931, New York: Oxford University Press, 1991.

Gauss, C.E., 'Monthly Political Review' various reports. Tientsin: American Consulate General, 1930, reprinted in Confidential U.S. State Department Central Files: China - Internal Affairs, 1930-1939, Frederick: University Publications of America, c. 1984.

Gilbert, Rodney, What's Wrong With China, New York: Frederick A. Stokes, 1926.

Gillin, Donald G., Warlord Yen Hsi-shan in Shansi Province, 1911-1949, Princeton: Princeton University Press, 1967.

Gregory, J.S., Great Britain and the Taipings, Canberra: Australian National University Press, 1969.

Hart, Robert, The I.G. in Peking: Letters of Robert Hart, Chinese Maritime Customs 1868-1907. Eds. John King Fairbank, Katherine Frost Bruner and Elizabeth MacLeod Matheson, 2 vols. Cambridge: Belknap Press, 1975.

—_, Entering China's Service: Robert Hart's Journals, 1854-1863. Eds Katherine F. Bruner, John K. Fairbank and Richard J. Smith, Cambridge and London: Council on East Asian Studies, Harvard University, 1986.

- Robert Hart and China's Early Modernization: His Journals, 1863-1866, Cambridge and London: Council on East Asian Studies, Harvard University, 1991. Hewitt, Anthony, Children of the Empire, Kenthurst: Kangaroo Press, 1995. Hewlett, Meyrick, Forty Years in China, London: Macmillan, 1943.

Hill, S. Charles, 'Pirates of the China Seas: Adventures of East and West in Quelling Sea-Roving Enemies of the Human Race', Asia Apr. 1924: 306-28. 
Jain, J.P., China in World Politics: A Study of Sino-British Relationsh 1949-1975, New Delhi: Radiant Publishers, 1976.

King, Frank H.H., The Hongkong Bank in the Period of Imperialism and War, 1895-1918: Wayfoong, the Focus of Wealth, vol. 2 of History of the Hongkong and Shanghai Banking Corporation, New York: Cambridge University Press, 1988.

- and Clarke, Prescott (eds), A Research Guide to China Coast Newspapers, 1822-1911, Cambridge: Harvard University Press, 1965.

King, Paul, In The Chinese Customs Service: A Personal Record of Forty-Seven Years, New York and London: Garland Publishing, 1980.

King, Yvonne, 'A Variegated Life', ts., c.1990.

$\longrightarrow$, Personal interview, 26 July 1998.

Kirke-Green, Anthony, On Crown Service: A History of HM Colonial and Overseas Civil Services 1837-1997, London: Taurus, 1999.

—, Britain's Imperial Administrators, 1858-1966, London: Macmillan, 2000.

Lai, Chi-Kong, 'The Historiography of Maritime China since c. 1975', Research in Maritime History, 9 (Dec. 1995): 53-79.

Lampson, Miles, The Killearn Diaries: The Diaries of Sir Miles Wedderburn Lampson, ms. Middle East Centre, St Antony's College, University of Oxford, Oxford.

Lee, Bradford A., Britain and the Sino-Japanese War, 1937-1939: A Study in the Dilemmas of British Decline, Stanford: Stanford University Press, 1973.

Lee, En-Han, 'China's Recovery of the British Hankow and Kiukang Concessions in 1927', Occasional Paper no. 6. Nedlands: Centre for East Asian Studies, University of Western Australia, Aug. 1980.

Liao, Kuang-sheng, Antiforeignism and Modernization in China, 2nd ed. Hong Kong: Chinese University Press, 1986.

Louis, Wm. Roger, British Strategy in the Far East 1919-1939, Oxford: Clarendon Press, 1971.

Luard, Evan, Britain and China, London: Chatto \& Windus, 1962.

McCormack, Gavan, Chang Tso-lin in Northeast China, 1911-1928: China, Japan and the Manchurian Idea, Stanford: Stanford University Press, 1977.

_- 'Manchukuo: Constructing the Past', East Asian History, 2 (Dec. 1991): 105-24.

McKay, Alex, Tibet and the British Raj: The Frontier Cadre 1904-1947, Richmond: Curzon, 1997.

Manchukuo Government, Bureau of Information and Publicity, Department of Foreign Affairs, Manchukuo Handbook of Information, Hsinking: Manchukuo Government, 1933.

The Maze Collection, National Maritime Museum, Greenwich.

Maze, Frederick, The Chinese Maritime Customs Service: a Brief Synopsis of its Genesis and Development, N.p.: n.p., c.1940. Archived at the Library of the National Maritime Museum, Greenwich.

— - The Papers of Sir Frederick Maze Relating to the Chinese Maritime Customs Service, 1900-1943, The Library of School of Oriental and African Studies, London.

Miners, Norman, Hong Kong Under Imperial Rule 1912-1941, New York: Oxford University Press, 1987. 


\section{Bibliography}

Morrison, G.E. Letter to E. Taylor. 17 Apr. 1917. G.E. Morrison Papers Collection, Mitchell Library, Sydney.

Nevill, Ralph, London Clubs: Their History and Treasures, London: Chatto and Windus, 1911.

Nish, Ian, Japan's Struggle With Internationalism: Japan, China and the League of Nations, 1931-3, London: Kegan Paul International, 1993.

North-China Daily News, 1914-1933.

North-China Herald.

Osterhammel, Jürgen, 'Imperialism in Transition: British Business and the Chinese Authorities, 1931-37', The China Quarterly, 98 (June 1984): 260-86.

— 'Semi-Colonialism and Informal Empire in Twentieth Century China: Towards a Framework of Analysis', Imperialism and After: Continuities and Discontinuities, Eds. Wolfgang J. Mommsen and Jürgen Osterhammel, London: Allen and Unwin, 1986, pp. 290-314.

Paauw, Douglas S, 'The Kuomintang and Economic Stagnation, 1928-1937', Journal of Asian Studies, 16 (1956-7): 213-20.

Pratt, John T., War and Politics in China, London: Jonathon Cape, 1943.

Preston, Anthony and John Major, Send A Gunboat! A Study of the Gunboat and its Role in British Policy, 1854-1904, London: Longmans, 1967.

Rassmussen, A.H., China Trader, London: Constable and Company, 1954.

Rawski, Thomas G., Economic Growth in Prewar China, Berkeley: University of California, 1989.

Rigby, Richard, The May 30 Movement: Events and Themes, Canberra: Australian National University Press, 1980.

Selle, Earle Albert, Donald of China, Sydney: Invincible Press, 1948.

Sharman, Lyon, Sun Yat-sen, His Life and Meaning: A Critical Biography, Stanford: Stanford University Press, 1934.

Sheridan, James E., Chinese Warlord: The Career of Feng Yü-hsiang, Stanford: Stanford University Press, 1966.

Spence, Jonathan D., God's Chinese Son: The Taiping Heavenly Kingdom of Hong Xiuquan, London: Harper Collins, 1996.

Starr, John Bryan, Understanding China, London: Profile Books, 1997.

Stormrail (pseud.), Pirates and Perils, London: The Sheldon Press, n.d.

Strauss, Julia C. Strong Institutions in Weak Polities: State Building in Republican China 1927-1940, Oxford: Clarendon, 1998.

Sun Yat-sen, San Min Chu I: The Three Principles of the People, Trans. F.W. Chen. Ed. L.T. Chen. Calcutta: Chinese Ministry of Information, 1942.

Tien, Hung-Mao, Government and Politics in Kuomintang China, 1927-1937, Stanford: Stanford University Press, 1972.

The Times, London.

Trotter, Ann, Britain and East Asia 1933-1937, London: Cambridge University Press, 1975.

— , 'Backstage Diplomacy: Britain and Japan in the 1930s', Journal of Oriental Studies, 15, 1 (Jan. 1977): 37-45.

- , ed., British Documents on Foreign Affairs: Report and Papers From the Foreign Office Confidential Print, part 2, series E, vols. 19-41. Frederick: University Publications of America, 1984.

Weale, Putnam [B. Lenox Simpson], Why China Sees Red, London: Macmillan, 1926. 
Weber, Max, 'Authority and Legitimacy', Politics and Society: Studies in Comparative Political Sociology, ed. Eric A. Nordlinger, Englewood Cliffs: Prentice Hall, 1970, pp. 35-44.

Welsh, Frank, A History of Hong Kong, London: Harper Collins, 1993.

Wesley-Smith, Peter, Unequal Treaty 1898-1997: China, Great Britain and Hong Kong's New Territories, Hong Kong: Oxford University Press, 1980.

Wilbur, C. Martin, Sun Yat-sen: Frustrated Patriot, New York, Columbia University Press, 1976.

_ ' 'The Nationalist Revolution: From Canton to Nanking, 1923-28', Republican China 1912-1949, vol. 12 of The Cambridge History of China, ed. John King Fairbank, New York: Cambridge University Press, 1983.

- The Nationalist Revolution in China, 1923-1928, Cambridge: Cambridge University Press, 1984.

Williams, C.A.S., Chinese Tribute, London: Literary Service and Production, 1969.

Woodhead, H.G.W., ed. The China Yearbook (various editions), Tientsin: Tientsin Press, 1912-37.

Wright, Stanley F., The Collection and Disposal of the Maritime and Native Customs Since the Revolution of 1911, with an Account of the Loan Services Administered by the Inspector General of Customs, 2nd ed. Shanghai: Statistical Department of the Inspectorate General of Customs, 1927.

— Hong Kong and the Chinese Customs, Inspectorate Series number 7, Shanghai: Statistical Department of the Inspectorate General of Customs, 1930.

_- China's Struggle for Tariff Autonomy: 1843-1938, Shanghai: Kelly and Walsh, 1938.

_ Hart and The Chinese Customs, Belfast: W. Mullan, 1950.

Wright, Tim, 'Coping With the World Depression: The Nationalist Government's Relations With Industry and Commerce, 1932-1936', Modern Asian Studies, 25, 4 (1991): 649-74.

Young, Louise, Japan's Total Empire: Manchuria and the Culture of Imperialism, London: University of California Press, 1998. 


\section{Index}

Pages containing relevant illustrations are indicated in italic type. Chinese names have not been inverted.

Abend, Hallett 135, 183n. 2

accommodation 48-9, 49-50

accounts 23,25

Acheson, Guy Francis Hamilton 42, 44

Aglen, Sir Francis 1, 2, 7, 20, 30-1, 65, $70,75-6,88,89-90,112,144-5$,

175n. 117; dismissal 78, 79-81, 86-7;

Guangzhou controversy $62,63,64$;

London Office 38-9, 40, 40-1; staff

27, 28, 42, 44-5

Aitchison, Jean 9, 165n. 1

amahs 47

America see United States

Anderson, James 46

Anglo-Chinese Agreement (1943) 156, 157

Anglo-Chinese Tariff Agreement (1929) 93

anti-British feeling see antiforeignism/anti-imperialism

anti-foreignism/anti-imperialism 2, 19 , 58-9, 60, 65-7, 68, 68-9, 70, 156-7;

Guangzhou-Hong Kong boycott

68-78; May 30th incident (1925)

65, 67-8; Nanjing Incident 82 , 84-6

Arlington, L.C. 123, 184n. 21

Assistants 27, 43

Atkins, Martyn 89

banditry $58-9$

Bank of Communications 121

Barton, Sir Sidney 91

Beijing 19, 47-8, 68, 90, 99

Beijing regimes 55, 56, 57, 78, 80, 81, $83,87,89,123,124$
Bell, Colonel Hayley 71, 72-5, 109-10, 119, 175n. 110; Tianjin Customs seizure $121,123,130-1$

'beneficial' school, Sino-Western relations 3-4

Bickers, Robert 3, 9

Bolsheviks 65, 70, 78

Bowra, Cecil 39, 40-1, 62

Boxer Rebellion (1900) 19

boy, position of 170n. 116

boycott, Guangzhou-Hong Kong 67-78

Brenan, Acting Consul General 76

brigandage 58-9

Briggs, Captain Christopher 51, 149, 150,189 n. 57

British dominance 17-18, 61-2; see also London Office

British imperialism see imperialism

British interests 1-2, 45, 81, 83-4, 147; conflict with Maze 95-6; decline 156-7, 158; Hong Kong-China Trade and Customs Agreement 110-11; Japanese invasion 149-50; Nanjing Incident 82, 84-6; Sino-Japanese War 153; succession crisis 83-4, 86-95; Tianjin Customs seizure 126-8; see also foreign interests/powers; London Office

Burlingame, Anson 17-18

Campbell, James 37-8, 40, 43

Canton see Guangzhou

Chamberlain, Austen 96

Chen Jidang 131

Chen Jiongming 55, 171n. 2 
Chen Mingshu 131

Chiang Kai-shek see Jiang Jieshi

children of staff 47

China Association 112

China Year Book (CYB) 31-2, 32, 103

Chinese Communist Party (CCP) 65, 66, 68

Chinese Government see Nationalist Government

Chinese language learning 27-8

Chinese legation, tensions with London Office 40

Chinese Maritime Customs Project xii

Chinese staff 16-17, 26-7, 45, 73-4, 99-100

Chinese workers' unions, Hong Kong 69

Christianity 10

'civilizing mission' 172n. 40

Clementi, Sir Cecil 73, 105, 106, 111, 175n. 110

Clifford, Nicholas 2

colonialism see imperialism

Commissioners see Customs

Commissioners

communication network, London Office 40-1

consuls, British/American/French 11

Customs, pre-IMCS/CMCS 10

Customs Agreement (1938) 153

Customs Commissioners 16, 18, 23, 25 , $45,51,52,143$; accommodation $48-9,49-50$

Customs cruisers see Customs vessels

Customs houses 12-13, 14, 23; seizure in Manchuria 119, 134-46; see also Customs Commissioners; staff

'Customs man' type 41-2

Customs vessels: Japanese aggression 151-2; social functions 52,52

CYB see China Year Book

Dairen see Dalian

Dalian, Customs house seizure 136, 140-2

Dayer, Roberta 172n. 26

December Memorandum (1926) 84

Ding, Chinese Secretary (Ting Kweitang) 137

duty-free area, Zhongshan 115-16

Edwardes, Commissioner Arthur 70, 82, 86, 88-95, 145, 178n. 43; Tianjin Customs seizure 121 empire see imperialism; informal empire theory

Endicott, Stephen 31

Eurasian community 51-2

examinations, recruitment 42-3

exhibitions, Chinese 40

export duty 36

Fairbank, John King 8-9, 162n. 21

family life, staff $45-9,49-50,51-2$, $52-3,53$

Father of the Republic see Sun Yatsen

Feng Yuxiang 113, 119, 120, 122-3, 125-6, 127, 183nn. 3-4

Financial Medals 30

First World War 20

Fitzgerald, John 173n. 59

FO see Foreign Office

foreign interests/powers 1-2, 8, 10, 37; Guangzhou Customs controversy 54-67, 173n. 46; Nanjing era 82, 83; see also British interests; France; Japan; United States

foreign loans 31-2, 34, 34-5; SinoJapanese War 152, 153

Foreign Office 2, 85-6, 93, 95, 138; Hong Kong-China Trade and Customs Agreement 110-11, 116-17; revenues, Sino-Japanese War 152; succession crisis 86, 91; tariff agreements 93-4; Tianjin Customs seizure 128, 129; see also Lampson, Sir Miles

foreign powers see foreign interests/powers

France 128; Shaji bridge incident 76

free ports, Zhongshan 115-16

Fu Bingxiang 177n. 43

Fukumoto, Commissioner 137, 140-2, 144-5

Fung, Edmund 2, 93

Gilbert, Rodney 61

GMD see Guomindang

Gong Qinwang, Prince 14

governesses 47

government see Nationalist Government

Green, Owen Mortimer 60

Guandong (Kwantung) Army 119, 134, 135

Guangzhou 11-12, 119, 131-3; Customs controversy 54-67, 173n. 46; Hong Kong-China Trade and Customs Agreement 115-16 
Guangzhou-Hong Kong boycott 67-78

Guangzhou-Kowloon Railway Working Agreement 104

guanxi 29, 166n. 31

gunboat diplomacy 60-2, 64, 67, 84

Guomindang (GMD) 2, 19, 45, 65-6, 78, $82,87,88,94-5$; civil war 113,119 , 120; Guangzhou Government 119, 131-3; Manchuria Customs house seizures 139; and Maze 94-5, 97, 98-9, 100; Nanjing Incident 82, 84-6; tariff agreements 93, 99; Tianjin Customs seizure 119, 120, 124-5, 126, 129-31; see also Sun Yatsen

Hankou protests $68-9$

Harbin, Customs house seizure 143

Harris, A.H. 62

Harris Agreement (1910) 104, 106

Hart, Robert 1, 6, 11-12, 14, 15-19, 19-20, 104, 118, 164nn. 64 \& 79, 167n. 57; London Office 37-8, 40, 167 n. 60

health, staff 44-5

Hewlett, Meyrick 85

holidays, staff 48

Hong Kong 151-2; Guangzhou-Hong Kong boycott 67-78; relationship with China 104; relationship with CMCS 102-3, 104, 104-5; smuggling 102, 103, 104, 105-6, 109-10

Hong Kong and Shanghai Banking Corporation 21, 43

Hong Kong-China Trade and Customs Agreement (1929-30) 41, 101-2, 105, 106-17

Hong Xiuquan 10

imperialism 3, 5, 9, 61-2, 64-5, 172n. 40; gunboat diplomacy 60-2, 64, 67, 84; see also anti-foreignism/ anti-imperialism

Imperial Maritime Customs Service (IMCS, pre-CMCS) 1, 8-9, 15-19, 40; origins $10-11,12-13,14-21$

import duty 36

income tax ruling, London Office 38-9 informal empire theory 9

inland river systems: piracy 10,103 ; trade 102, 107, 109, 111

Inspectors General/Inspectorate 1, 22, 23, 155, 157; succession crisis 83-4, 86-95; see also Aglen; Hart; Lay; Little; Maze
Japan 148, 149; Guandong (Kwantung) Army 119, 134, 135; GuangzhouHong Kong boycott 70; Manchuria Customs seizures 134-46; Pacific War 153-4, 157-8; Sino-Japanese War 147, 150, 150-3; support for Edwardes 88, 90; trade 20, 127

Jiang Jieshi (Chiang Kai-shek) 120, 131, 156

Johnston, Commissioner 84-5

journalists, and warlords 119, 182n. 2

King, Paul 20

King, Yvonne 25, 29, 46, 47, 48, 49-50, 51

Kishimoto, Chief Secretary 90

Kong Xiangxi (Dr H.H. Kung) 153, 155, 188n. 38

Kowloon 113; smuggling 105-6, 109-10

Kung, Dr H.H. see Kong Xiangxi

Kuomintang see Guomindang

Kwantung (Guandong) Army see Guandong (Kwantung) Army

Lampson, Sir Miles 49, 79, 138; Aglen dismissal 80, 81; Hong Kong-China Trade and Customs Agreement 110, 112, 113, 114, 116-17; Nanjing Incident 85-6; succession crisis 83-4, 86-93, 95, 96, 97-8, 100; Tianjin Customs seizure 121, 122-3, 126-7, $128-9$

Lappa district, smuggling 105-6, 109-10

Law, W.O. 134

Lay, Horatio Nelson 1, 11, 14

Le Bas family see King, Yvonne

Lincheng incident 58

Little, Lester Knox 1, 157, 158

LO see London Office

loan servicing $34-5$

lobby groups, Hong Kong-China Trade and Customs Agreement 109

London Office (LO) 37-45, 138, 167nn. 56 \& 60; Hong Kong-China Trade and Customs Agreement 108-9; staff recruitment 41-5

Longjing, Customs house seizure 143

MacDonald, Malcolm 97-8

Macleay, R. 57-8, 58-9, 60, 77

Macoun, C. 41

Manzhuguo (Manchukuo) Government, Customs house seizures 119, 134-46 marriage, staff 44,47 
May 30th incident (1925) 65, 67-8

Maze, Sir Frederick xi, 1, 2, 6, 23, 41, 95-100, 118, 147, 188nn. 34 \& 38; Guangzhou compromise 131-3; Hong Kong-China Trade and Customs Agreement 101-2, 105, 106, 108, 108-14, 115-17; Japanese occupation 148, 151, 153; Manchuria Customs house seizures 134, 136, 137-40, 141, 143-5; Pacific War 154-5, 156-7; resignation 155-6; succession crisis 86, 87, 88-95; Tianjin Customs seizure $119,121,122,123,125$, 126-7, 128-9, 130-1

Medal for Meritorious Service 30 medicals, recruits 44 mental breakdown, staff 45 military expenditure 34 Morrison, G.E. 25-6 music, IMCS 17

Nakamura, Captain 135, 185-6n. 83

Nanjing decade 31, 45; Hong Kong-China Trade and Customs Agreement (1929-30) 41, 101-2, 105, 106-17; succession crisis 83-4, 86-95, 96, 97-8; Tianjin Customs seizure (1930) 118-19, 119-31, 124-5

Nanjing Government 82, 83, 99, 118, 139; civil war 119, 120; condemnation of Edwardes 145; policy re Manzhuguo 134, 136, 138; see also Jiang Jieshi

Nanjing Incident (1927) 82, 84-6

National Import Tariff (1929) 103

nationalism, Chinese 2, 19

Nationalist Government 21, 90-1, 92, 131; finance 31-2, 33, 34-5, 36, 36-7; and Hong Kong 101-2, 103, 105, 113, 115-16; Nanjing Incident 82, 84-6; Sino-Japanese War 152; Sino-Western relations 79-81, 81-2, 83, 88-9; see also Guomindang; Nanjing Government

NCDN see North-China Daily News

$\mathrm{NCH}$ see North-China Herald

New Territories 102, 104

Non-Resident Secretary (NRS), post of 37, 38, 39, 40, 41, 43, 45

North-China Daily News (NCDN) 61, $94,112,123,124-5,133,140,141-2$, 142

North-China Herald (NCH) 148-9

Northern Expedition 79, 82, 113, 120 opium revenue 34

Opium Wars 10

'oppression' school, Sino-Western relations 3-4

Osborn, Captain Sherard 14

Osterhammel, Jürgen 3, 31

outdoor staff see staff

Pacific War 153-8

Pauuw, Douglas 31

Peace Protocol (1901) 19

Peel, Sir William 111-12, 113-14

Peking see Beijing

piracy $10,102,103$

ports $1,3,8-9,11-12,12-13,16$, 184n. 38; staff rotation 46; see also Customs Commissioners; Customs houses

Pratt, Sir John T. 62, 77

Prettejohn, Commissioner 143, 144

property, wartime loss $157-8$

punishment/reward, staff $27-30$

Qing court 10-11, 14, 19

racism $51-2$

Rasmussen, A.H. 18, 26, 28-9, 44

rational bureaucracy 9

Rawski, Thomas 31

recruitment $41-5$

Reorganizationists' movement 131

Republic of China 9, 19-21, 22; finance 30-2, 33, 34-5, 36, 36-7; and London Office 40; relationship with Hong Kong 104; see also Nationalist Government

research 4

revenue $19,20-1,23,33,35,36$;

Guangzhou Customs controversy

54-67, 173n. 46; north-eastern provinces 136; salt 33, 56-7; SinoJapanese war 152

revolution (1911) 19, 20

river systems see inland river systems

salt revenue $33,56-7$

salt smuggling $28-9$

San Min Zhuyi (The Three Principles of the People) 66, 173n. 62

Schjoth, Acting Deputy Commissioner 69, 70-1

Second World War see Pacific War

Shaji bridge incident, Shamian 69-70, 76 
Shanghai 11, 44, 99; Japanese attack 135; Japanese takeover 151, 152; May 30th incident 65, 67-8

Simpson, Bertram Lenox 119, 122-5, 128-9, 130, 131

sinicization of CMCS 99-100

Sino-Japanese tensions, Manchuria 134-46

Sino-Japanese War 147, 150, 150-3

Sino-US Agreement (1928) 93

Sino-Western relations 3-4, 8-9, 15-16, 79-81, 81-2, 83, 88-9

Small Sword Society 11

smuggling 28-9, 102, 103, 104, 105-6, 109-10, 115, 149, 150-1

social scene 44, 45-6, 48, 49, 50, 51-2, $52-3,53$

Sokolsky, George 61

Song Ziwen (T.V. Soong) 32, 86, 115, 116,141

South-East China Coast Investigation Commission 109-10

South Manchurian Railway Company (SMR) 135

Soviet Union 65, 78

staff 17-18, 22-3, 24-5, 25-7, 47-8, 99; Chinese 16-17, 26-7, 45, 73-4, 99-100; family life $45-9,49-50$, 51-2, 52-3, 53; First World War 20; London Office 39-40, 167n. 60; Manchuria Customs house seizures 143-4; Pacific War 157, 158; recruitment 41-5; regulation/reward 27-30

Stephenson, Commissioner 108-9, 113, 132

strikes, Guangzhou-Hong Kong boycott $69,70-8$

studies 4

succession crisis $83-4,86-95,96,97-8$, 100

Sun Yatsen (Sun Yixian) 4, 97, 173nn. 59 \& 62; Guangzhou Customs controversy $54-67,173 \mathrm{n} .46$

synarchy 8-9

Taiping Rebellion 10-11

taotai of Shanghai 11

tariff autonomy 19, 93-4, 99, 103
Tianjin, smuggling 150-1

Tianjin Customs seizure (1930) 118-19, 119-31, 124-5

Tien, Hung-Mao 31

Tientsin see Tianjin

Ting Kwei-tang see Ding

trade $20,102,111,121-2,127,149$;

inland 102, 107, 109, 111

treaty ports see ports

Tyrell, Sir W. 77

uniform 17, 164n. 64; Bell 71

United States 77, 127-8, 155, 156, 157;

Sino-US Agreement 93

von Grumpach case 167n. 57

Wallas, Commissioner 143

Wang Jingwei 131

warlords 21, 113, 118-19, 119-20, 120, 121-3, 125-6, 182n. 2, 183nn. 3-4;

Feng and Yan 113, 119, 120, 121, 122-3, 125-6, 127, 128, 183nn. 3-4

wars: civil war 113, 119, 120; First

World War 20; Opium Wars 10;

Pacific War 153-8; Sino-Japanese War 147, 150, 150-3

Weber, Max 9

Western culture, IMCS 17

Western interests see foreign interests/powers

Williams, C.A.S. 26-7, 27-8, 49, 52, 103

Wright, Stanley Fowler 7-8, 36, 105, 107

Wright, Tim 31

Wu Chaoshu 56

Yan Xishan 113, 119, 120, 121, 122-3, 125-6, 127, 128, 183n. 4

Yokohama Specie Bank 152

Yuan Shikai 21

Zhang Xueliang 119, 126, 129

Zhang Zuolin 83, 87, 183n. 2

Zhifu 149, 150

Zhongshan, Hong Kong-China Trade and Customs Agreement 115-16

Z Series Letters 41, 167n. 56 